TESE DE DOUTORADO

ADRIANA GRANDIS

PAPEL DAS ENZIMAS DE DEGRADAÇÃO DA PAREDE CELULAR NA FORMAÇÃO DO AERÊNQUIMA EM RAÍZES DE CANA DE AÇÚCAR

Role of cell wall degradation enzymes during the aerenchyma formation in sugarcane roots 


\title{
PAPEL DAS ENZIMAS DE DEGRADAÇÃO DA PAREDE CELULAR NA FORMAÇÃO DO AERÊNQUIMA EM RAÍZES DE CANA DE AÇÚCAR
}

\author{
Role of cell wall degradation enzymes during the aerenchyma \\ formation in sugarcane roots
}

Tese apresentada ao Instituto de Biociências da Universidade de São Paulo, para a obtenção de Título de Doutor em Ciências, na Área de Biologia de Sistemas.

Orientador: Marcos S. Buckeridge 
FICHA CATALOGRÁFICA

GRANDIS, Adriana

Papel das enzimas de degradação da parede celular na formação do aerênquima em raízes de cana de açúcar $122 p$.

Tese (Doutorado) - Instituto de Biociências da Universidade de São Paulo. Departamento de Botânica.

1. glicosil hidrolases 2. Proteômica 3. Morte celular programada 4. Parede cellular 5. Aerênquima

I. Universidade de São Paulo. Instituto de Biociências. Departamento de Botânica. Janeiro de 2015. 


\section{Comissão Julgadora:}

Prof(a). Dr(a).

Prof(a). Dr(a).

Prof(a). Dr(a).

Prof(a). Dr(a).

Prof. Dr

Orientador 
À todos que me ajudaram nesta tese e ajudam diariamente na minha vida. 
"Talvez não tenha conseguido fazer o melhor, mas lutei para que o melhor fosse feito. Não sou o que deveria ser, mas Graças a Deus, não sou o que era antes".

(Marthin Luther King) 


\section{AGRADECIMENTOS}

Ao meu orientador Marcos Buckeridge pela oportunidade de trabalho.

A comissão julgadora que compõe a banca que contribuíram para o aprimoramento desta tese.

A Benedetta Mattei, Felice Cervone e Julia Di Lourenzo que me receberam de braços abertos na Itália, obrigada pela oportunidade.

Aos pesquisadores, professores e alunos do Departamento di botanica - Univercità di Roma La Sapienza, grandes amigos que fiz na Itália. Grandi amici. Grazie per tutto.

Ao João (Johnny), grande amigo que fiz na Itália que me ajudou nos momentos mais dificieis que passamos longe de casa. Obrigada Joãooooo.

Ao Laboratório de química da profa. Glaucia de Souza, por ceder os iniciadores utilizados nessa tese.

Ao laboratório do prof. Dr. Leonardo D. Gómez da Universidade de York-UK que auxiliou nas análises de sacarificação.

Ao laboratório de proteínas da pesquisadora Adriana Paes Leme e a equipe técnica, que me auxiliou nos primeiros ensaios de proteômica e também na análise de dados.

Ao pessoal do Laboratório de Anatomia do IB por toda a ajuda.

Meus imensos agradecimentos à todo o pessoal do Gate-Lab, pela ajuda com os trabalhos de Biomol, todo o socorro prestado e pelos momentos de alegria. Em especial, profa. Marie-Anne Van Sluys, Tati, Nathalia, Jonas, Paula, Érika e todo o pessoal que me ajudou de alguma forma.

À pós-graduação do Instituto de biociências da USP, pelo serviço e pela atenção.

À Fapesp pela concessão das duas bolsas, Bepe-Itália (2013/0159-0) e Doutorado (2011/17070-3).

A equipe do nosso laboratório Eglee e Vivi, que me ajudou muito durante os experimentos, durante as dificuldades, sem elas tudo seria mais difícil e triste.

Ao Edu, Joan e Marcela, da Unicamp pela amizade e pela oportunidade de aprender ainda mais.

Não foram só os 4 anos desta tese, mas foram mais de 8 anos trabalhando no Lafieco, então não posso deixar de agradecer à todos que passaram por esse Lab e deixaram sempre algum ensinamento e fizeram da minha vida mais feliz. Sendo assim agradeço à todos os alunos e amigos que passaram pelos Laboratórios do Dep. De Botânica. 
À Amanda de Souza pela amizade, pelos momentos de reflexão e por mostrar que a vida é muito mais que pensamos, e que nunca o que achamos que é nosso, realmente é. Obrigada por tudo, pela compreensão e pelo carinho.

A Débora, Eveline, Amanda Zisca, Grayce, os últimos dos moicanos (kkkk). Foram pessoas que contribuíram para esse trabalho ficar mais divertido, mais irreverente e não caísse na mesmice de todos os dias.

A minha grande amiga e irmã, que me encheu e me enche todo dia... me enche de alegria, de esperança, de paz e de energia para enfrentar essa longa jornada da nossa vida. Só tenho a te agradecer Bruna Arenque Musa por toda essa compreensão, amor, dedicação e respeito. Por abrir a porta da tua casa e da tua família que amo muito. Nem 1/3 dessa tese seria, se não fosse você me apoiando. Obrigada (:)

A Dani Gaona, pela amizade e por me ouvir sempre... desde os piores momentos que passei a km de distância do Brasil, até os momentos felizes ao vivo e a cores!

Aos meus grandes amigos de sampa, que fizeram dos momentos mais difíceis os mais divertidos. Que me fizeram sair da cama para ir dar um rolê de bicicleta ou ir ao Bar do Luis. Obrigada por tudo e por existirem !!!

Aos meus amigos e família (Grandis e Mazzero) de Piracity, que entenderam toda a minha ausência nesses 8 anos de estudo. Obrigada.

A minha avó Maria Ignês, por mostrar que a vida é mais simples do que imaginamos. Obrigada por ser tão compreensiva e serena.

Obrigada ao meu irmão Lucas, por ser companheiro e sempre mostrar o que é mais coerente ser feito. Obrigada pela serenidade e pelo exemplo de dedicação e competência. Amo você.

Aos meus pais que são meu suporte de amor, carinho e compreensão. Obrigada pelo grande exemplo que são na minha vida. Obrigada por me apoiarem nessa grande loucura que escolhi fazer. Amo vocês :)

E agradeço à Deus, por mais essa oportunidade de trabalho e de colocar todas essas pessoas na minha vida para que eu aprenda a ser uma pessoa melhor. Obrigada. 


\section{ÍNDICE}

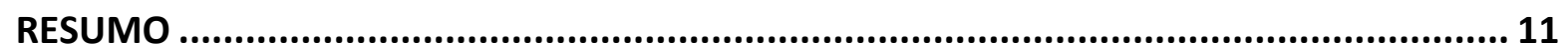

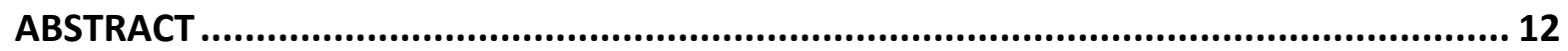

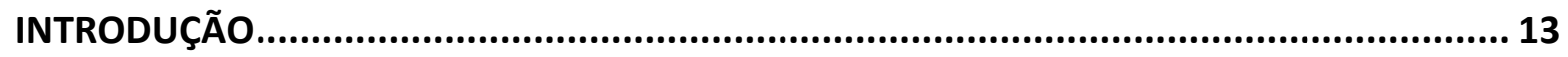

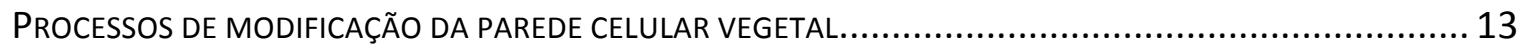

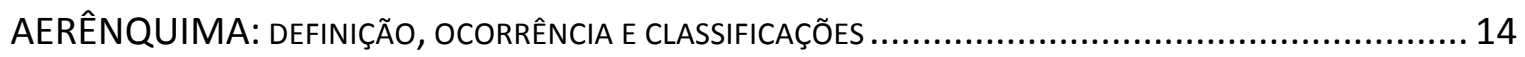

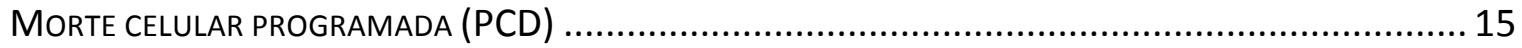

MODIFICAÇÕES QUE OCORREM NA PAREDE CELULAR DURANTE A FORMAÇÃO DO AERÊNQUIMA ............... 18

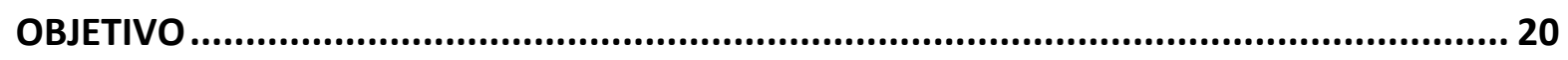

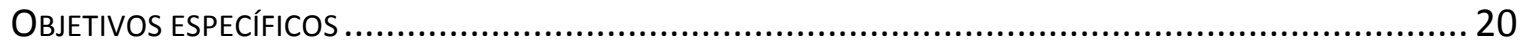

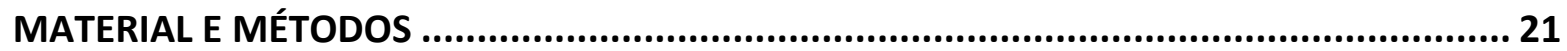

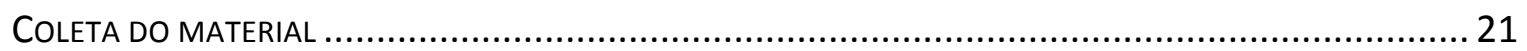

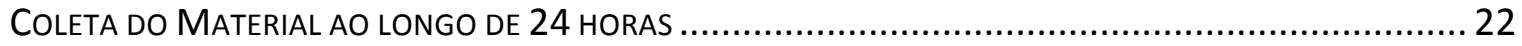

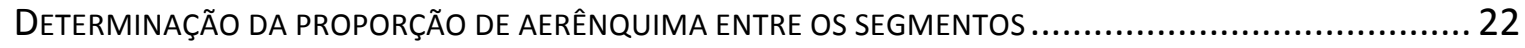

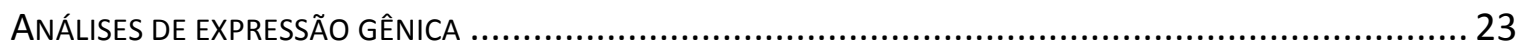

Desenho dos oligonucleotídeos específicos............................................................ 23

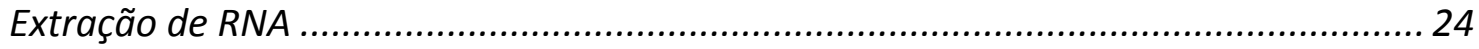

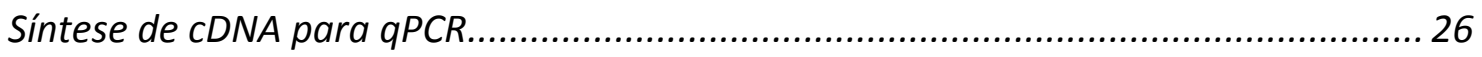

Análise de expressão gênica por PCR em tempo real................................................ 26

EXTRAÇÃO DE PROTEÍNAS TOTAIS SOLÚVEIS E ENSAIOS ENZIMÁTICOS ............................................... 27

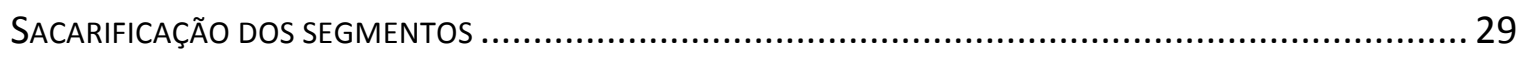

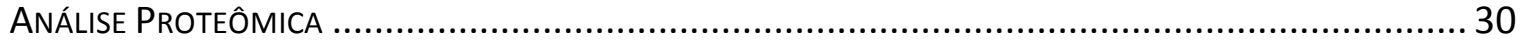

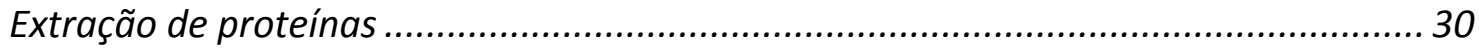

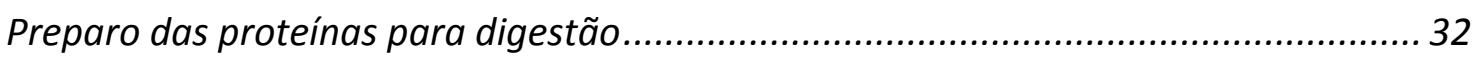

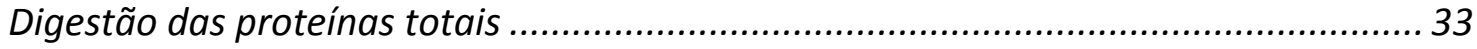

Peptídeos MultipleX: MARCAÇÃo dos PePtídeOS COM ISÓTOPOS de DIMETIL PARA A ANÁLISE dE

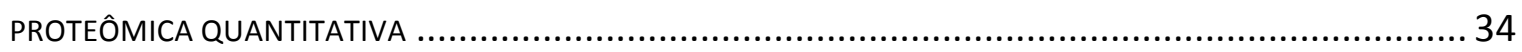

Identificação e quantificação das proteínas pela fragmentação de peptídeos ............. 37

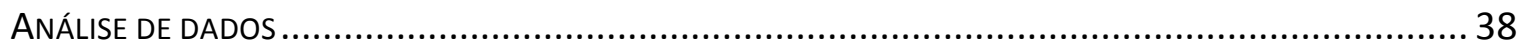




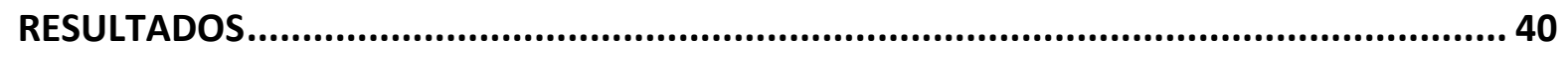

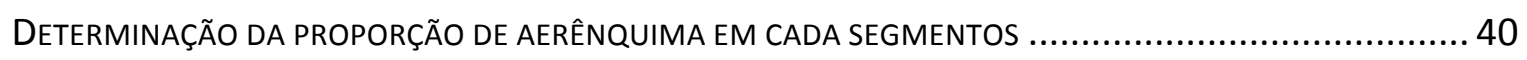

PROTEÍNAS SOLÚVEIS E IDENTIFICAÇÃo DAS HIDROLASES DE PAREDE CELULAR..................................... 41

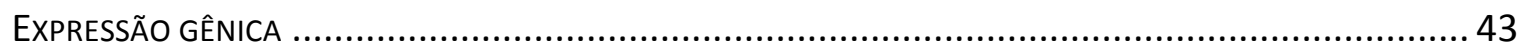

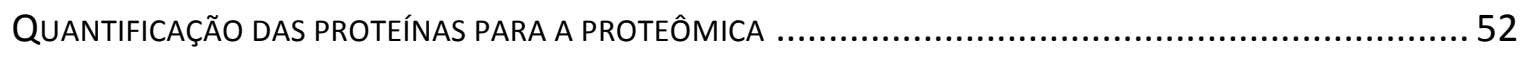

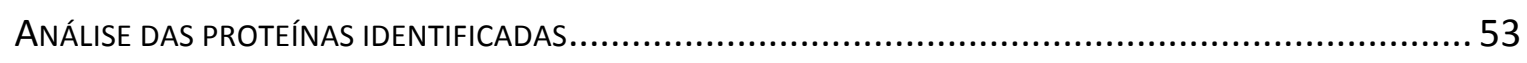

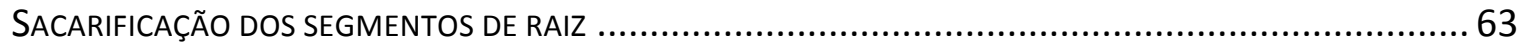

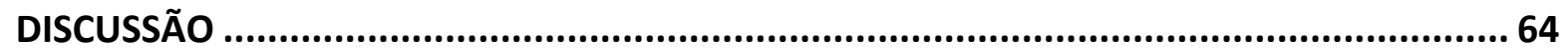

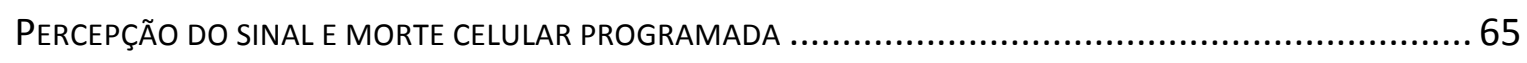

GLICOSIL HIDROLASES NAS MODIFICAÇÕES DA PAREDE CELULAR DURANTE A FORMAÇÃO DO AERÊNQUIMA 67 ACESSIBILIDADE DAS GLICOSIL HIDROLASES À ARQUITETURA DA PAREDE CELULAR DOS SEGMENTOS DE RAIZ 74

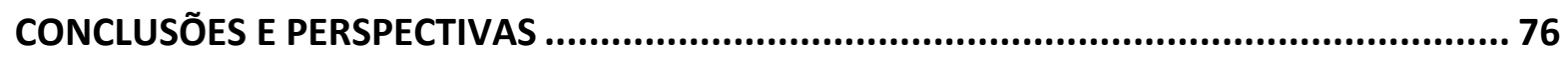

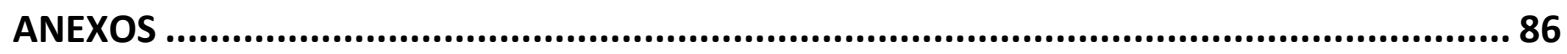




\section{RESUMO}

A resistência das paredes celulares vegetais à hidrólise enzimática é um dos grandes gargalos tecnológicos para a obtenção do etanol celulósico. Acredita-se que as modificações nas paredes celulares em processos como a mobilização de reservas, formação de aerênquima, amadurecimento de frutos e senescência, por exemplo, envolvam a ativação de módulos funcionais que culminam em alterações nas paredes celulares. Estes módulos são: 1) recepção de um sinal para início do processo; 2) Morte Celular Programada (PCD); 3) separação celular; 4) expansão celular; 5) hidrólise de hemiceluloses e 6) hidrólise de celulose. No caso da formação de aerênquimas lisígenos o processo que se inicia com a PCD e é seguido pela liberação de glicosil hidrolases que atuam a na degradação e/ou modificação da parede celular, formando espaços de ar no córtex radicular. A formação de aerênquima nas raízes de cana de açúcar é constitutiva e pouco se sabe sobre os mecanismos de modificação que ocorrem na parede celular durante este processo. Este estudo buscou compreender os padrões de variação expressão gênica, proteínas e de atividades enzimáticas associados à formação do aerênquima em raízes de cana de açúcar, com ênfase no papel das hidrolases de parede celular e em algumas proteínas relacionadas à PCD. Foram utilizados 5 segmentos de raízes de $1 \mathrm{~cm}$ cada, a partir do ápice radicular. No material coletado observou-se a formação gradual de aerênquima. Foram realizadas análises transcricional, proteômica e atividade enzimática das glicosil hidrolases e outras proteínas que atuam na modificação da parede celular, os quais foram identificados e quantificados ao longo da formação do aerênquima. As glicosil hidrolases pertencentes às famílias Cazy GH1, GH3, GH17, GH18 bem como expansinas, celulose sintase, lacase, calreticulina, calmodulina e proteínas relacionadas a degradação de pectinas, foram encontradas ao longo dos segmentos, principalmente após o segmento 2. De acordo com a atividade transcricional e dados da proteômica, sugere-se que os polissacarídeos seriam atacados por enzimas nos estágios iniciais da formação do aerênquima (seg 2 e 3). $O$ ataque ocorre principalmente sobre as pectinas e o $\beta$-glucano. Contudo, os dados apontam para a deposição de xiloglucano, xilanos e celulose (após seg 3), que formam um compósito ao redor dos espaços de ar. Isto sugere que parte dos polissacarídeos das paredes não sejam degradados ao longo do processo, embora enzimas específicas detectadas possam atuar na modificação dos mesmos, como verificado para algumas pectinases e membros de GH17. Além disso, nos pré-tratamentos com água foi possível observar que há maior sacarificação da parede nos seg. 1 e 2 . Contudo quando retira-se a maior parte das pectinas e hemiceluloses após prétratamento com $\mathrm{NaOH}$, a sacarificação é maior nos segmentos 2, 3 e 4, devido ao maior acesso e a maior quantidade de celulose. As glicosil hidrolases encontradas neste trabalho sugerem que estas atacam a parede de um específico conjunto de células do córtex que dá origem ao aerênquima. Já no fim do processo, quando há lise celular, algumas paredes de células remanescentes são recalcitrante à hidrólise, provavelmente devido a sua arquitetura e composição. Este trabalho traz informações para o desenvolvimento de futuras tecnologias para a produção do etanol do etanol celulósico de cana-de-açúcar.

Palavras chave: aerênquima, parede celular, glicosil hidrolases, proteômica, morte celular programada. 


\section{ABSTRACT}

The resistance of plant cell walls to enzymatic hydrolysis is one of the main bottlenecks of the development of technology of production of cellulosic ethanol. It is believed that the modifications in cell walls related to processes of storage mobilization, aerenchyma formation, fruit ripening and senescence, for instance, involve the activation of functional moduli that culminate in alterations of cell walls. These moduli are: 1 ) signal perception to start the process; 2 ) Programmed Cell Death (PCD); 3) cell separation; 4) cell expansion; 5) hydrolysis of hemicelluloses and 6) hydrolysis of cellulose. In the case of the formation of lysigenous aerenchyma, the process starts with PCD and is followed by the release of glycosil hydrolases that act on the degradation and/or cell wall modifications, forming air spaces in the cortex of the root. The formation of aerenchyma in the roots of sugarcane is a constitutive phenomenon and little is known about the mechanisms of modification that occur in cell walls during its development. Thus, the present study focused on the visualization of the patterns of variation of gene expression, proteins and enzyme activities associated to the formation of aerenchyma in roots of sugarcane in order to understand the role of the cell wall hydrolases and some proteins related to PCD in cell wall modifications along the process. Five root segments of $1 \mathrm{~cm}$ each, starting from root apex, were used. A gradual centripetal formation of aerenchyma was recorded in the cortex of developing roots. Analyses of the transcriptional, proteomic and enzyme activity profiles during the process revealed that several enzymes act on cell wall modifications. The glycosil hydrolases belonging to the Cazy families GH1. GH3, GH17, GH18, as well as expansins, cellulose synthase, laccase, calreticulin, calmodulin and other proteins related to pectin degradation have been found along the segments, mainly after segment 2. According to the data on transcriptomics and proteomics, it is suggested that enzymes attack polysaccharides during the initial stages of aerenchyma formation (seg. 2 and 3). The attack of the enzymes occurs mainly on pectins and $\beta$-glucan. Conversely, the data point out to the deposition (or maintenance) of xyloglucan, xylan and cellulose (after seg. 3), which form a composite that surrounds the air spaces. This suggests that part of the polysaccharides present in cell walls are not degraded during the process, although specific enzymes have been detected that could act on polysaccharide mobilization, such as the GH17 family. Further, under pretreatment with water, it has been observed that cell wall saccharification was higher at segments 1 and 2 . On the other hand, when most of the pectins and hemicelluloses are retrieved by pretreatment with $\mathrm{NaOH}$, saccharification is higher of segments 2, 3 and 4, probably due to the higher access to the wall and also to the higher proportion of cellulose. The profiles related to the glycosil hydrolases found in this work, suggest that these enzymes attack the cell wall. Initially, they are probably kept within a group of cells that will originate the aerenchyma. At the end of the process, when there is cell lysis, the remaining walls of some cells are recalcitrant to hydrolysis probably due to changes in their architecture and composition. Our findings bring promising information that could be used in the future to improve efficiency of hydrolysis for cellulosic ethanol production from sugarcane.

Key words: aerenchyma, cell walls, glycosil-hydrolases, proteomics, and programmed cell death 


\section{INTRODUÇÃO}

\section{Processos de modificação da parede celular vegetal}

Os polissacarídeos que estruturam a parede celular estão entrelaçados formando uma arquitetura complexa. Como resultado de processos de adaptação evolutiva, as paredes celulares vegetais desenvolveram a vital função de apresentar resistência ao ataque bioquímico exercido por organismos vivos, uma vez que são a primeira barreira entre as células e o ambiente. Sendo a parede celular vegetal um material recalcitrante à digestão enzimática, o ataque à estrutura para a liberação dos açúcares presentes é reduzido (Wingren et al. 2003).

O milho e a cana de açúcar são as espécies-chave já largamente empregadas na geração de bioenergia nos Estados Unidos e no Brasil, respectivamente (Ragauskas et al. 2006, Carpita e McCann 2008, Soccol et al. 2010). Além destas, gramíneas como Sorghum bicolor, Panicum virgatum (switchgrass) e as do gênero Miscanthus apresentam alto potencial para o emprego na indústria de biocombustíveis (Pauly e Keegstra 2008). As plantas supracitadas apresentam parede celular do tipo II devido às suas principais hemiceluloses serem compostas de glucano de ligação mista ( $\beta$-glucano) e arabinoxilano $(A X)$, além de um domínio péctico ser reduzido. O xiloglucano (XG) é encontrado em baixas concentrações, além de uma quantidade alta de compostos fenólicos (17-24\%) interligando os polissacarídeos, principalmente como ácido ferúlico (Silva 2005, Crivellari 2012, De Souza 2011, De Souza et al. 2013).

A hidrólise da parede é um dos principais processos necessários para a produção de bioetanol a partir da biomassa. Assim, encontrar e caracterizar as enzimas que possam acessar a complexidade das paredes celulares tem sido foco de muitos estudos (Gilbert 2014). Como resultado, os dados oriundos do uso de coquetéis enzimáticos contendo glicosil hidrolases de microrganismos está se tornando cada vez mais comum (Gòmez et al. 2008). Por outro lado, tem sido proposto o emprego biotecnológico de enzimas produzidas pelas próprias plantas, utilizando processos conhecidos em que espécies vegetais possuam parede celular mais acessível ao ataque destas enzimas (Grandis et al. 2014). 
A eficiência do processo de pré-tratamento para sacarificação da biomassa pode ser maior se for adquirido o controle sobre os mecanismos que as plantas possuem em degradar suas próprias paredes, de modo que o afrouxamento provocado por tais processos diminuiria a demanda de energia para o pré-tratamento e facilitaria a hidrólise. Em determinados momentos do desenvolvimento vegetal é possível observar que os mecanismos hidrolíticos provocam mudanças estruturais e bioquímicas em alguns órgãos. Estes sistemas provocam a modificação da parede celular, incluindo a hidrólise, para o desempenho de diferentes funções biológicas. Eles se iniciam com (1) as células alvo que têm a percepção de uma mensagem a partir do equilíbrio hormonal, (2) a separação das células, (3) a expansão celular, (4) morte celular programada (programmed cell death - PCD), (5) afrouxamento da parede/hidrólise de pectinas e hemiceluloses e (6) a hidrólise da celulose (Grandis et al. 2014). Esses processos naturais de modificação da parede celular ocorrem geralmente durante a formação do xilema (Mittler e Lam 1995), na senescência foliar, em tecidos de órgãos reprodutivos (Delong et al. 1993; Pennell e Lamb 1997), na mobilização de reservas (Buckeridge et al. 1992, Buckeridge 2010), no amadurecimento de frutos (Cavalari 2009) e na formação de aerênquima radicular (Evans 2003). Este último foi identificado em raízes de cana de açúcar, como resultado da modificação de parede celular incluindo a hidrólise de pectinas da lamela média e $\beta$-glucano (Leite 2013), porém as enzimas responsáveis por estas e outras modificações ainda não foram identificadas.

\section{AERÊNQUIMA: definição, ocorrência e classificações}

O aerênquima é um tecido especializado que pode se formar em folhas, pecíolos, caules e raízes consistindo em espaços intercelulares interligados longitudinalmente, que facilita a difusão de gases pelo tecido (Armstrong 1979). Pode atuar também como difusor de outros gases como metano, dióxido de carbono e etileno (Colmer 2003). É encontrado principalmente em raízes em resposta adaptativa a uma ampla gama de fatores ambientais que inclui hipóxia (Justin e Armstrong 1991, Drew 1997), resistência mecânica (He et al. 1996b), falta de nutrientes (Drew et al. 1989, Konings e Verschuren 1980, Bouranis et al. 2003) e a dessecação (Drew 1979). 
São encontrados dois tipos de aerênquima: o primeiro é denominado aerênquima cortical, como o encontrado em raízes de arroz (Oryza sativa), milho (Zea mays), cevada (Hordeum vulgare), trigo (Triticum aestivum) e cana de açúcar (Armstrong 1979, Evans 2003, Jackson e Armstrong 1999, Nishiuchi et al. 2012, Leite 2013). O outro tipo é um tecido branco e esponjoso preenchido com espaços de gás que se forma no caule, hipocótilos, raiz principal, raízes adventícias e nódulos radiculares de leguminosas, como a soja (Glycine max), Sesbania rostrata e Viminaria juncea cultivadas em condições de alagamento (Arikado 1954, Walker et al. 1983, Saraswati et al. 1992, Mochizuki et al. 2000).

O aerênquima pode ser resultado tanto de um processo esquizógeno quanto lisígeno (Arber 1920, Jackson e Armstrong 1999, Seago et al. 2005). O aerênquima esquizógeno, geralmente constitutivo, ocorre quando espaços gasosos intercelulares são formados durante o desenvolvimento, sem o processo de morte celular programada. Esses espaços são formados pelo crescimento celular diferencial, com células adjacentes separando-se umas das outras entre a lamela média, provavelmente com a digestão apenas da lamela média (Laan et al. 1989, 1991, Visser et al. 2003, Evans 2003). Um exemplo de aerênquima esquizógeno está no pecíolo de Sagittaria lancifolia (Schussler et al. 1997). O aerênquima esquizógeno é um processo complexo e ordenado, porém sua regulação e os elementos chave que levam à sua formação são pouco estudados (Evans 2003).

O aerênquima lisígeno, onde possuem maior parte dos estudos, pode ser constitutivo ou induzido (por alagamento ou etileno) e envolvem necessariamente morte celular programada seguido da degradação da parede celular. Pode ser encontrado em espécies de cevada (Arikado e Adachi 1955), trigo (Trought e Drew 1980), arroz (Justin e Armstrong 1991), milho (He et al. 1996a, Gunawardena et al. 2001a) e cana de açúcar (Leite 2013).

\section{Morte celular programada (PCD)}

O primeiro sinal que desencadeia todo o processo de formação do aerênquima lisígeno induzido é a redução do nível de oxigênio nas raízes, uma vez que na água a sua difusão de oxigênio 
passa a ser $10^{4}$ vezes menor que no ar (Armstrong e Drew 2002). Após a redução da oxigenação há o aumento do etileno e do $\mathrm{Ca}^{2+}$ citosólico e assim entra em execução todo o processo de PCD e consequente formação do aerênquima (Fagerstedt 2010).

Na formação lisígena, muitas plantas diferem no que diz respeito à dependência de um indutor ambiental para que o aerênquima se inicie. Em arroz, a formação de aerênquima não é induzida, pois alguns trabalhos mostraram que não depende de hipóxia para ser formado, ocorrendo mesmo em solos aerados (Kawai et al. 1998). Entretanto, mesmo quando é constitutivo, o etileno é requerido para sua formação (Yukiyoshi e Karahara 2014), contudo, para outras plantas a formação de aerênquima parece ser independente deste hormônio, como por exemplo em espécies de regiões alagáveis como Juncus effusus (Visser e Bogemann 2006). Já para espécies mais estudadas como o milho, a formação de aerênquima é induzida pela baixa concentração de oxigênio e/ou pelo aumento de etileno (Drew et al. 1989, Drew et al. 2000) que induzem a PCD. Entretanto, como visto por esses trabalhos, sinalizando ou não via etileno, as células recebem necessariamente a sinalização via cálcio, o que resulta na PCD e consequentemente formação do aerênquima lisígeno.

A PCD é um processo ordenado de suicídio celular que necessita de uma ativa expressão gênica, ocorre quando há um certo número de eventos do desenvolvimento e facilita com a remoção de tipos celulares específicos que não são mais exigidos (Lam et al. 2001). É conhecida por ocorrer durante eventos do desenvolvimento das plantas como na senescência de folhas e frutos, no desenvolvimento dos elementos traqueais, durante a hipersensibilidade em resposta ao ataque de patógenos e em eventos muito semelhantes a este ocorrem durante a formação do aerênquima sob estresses ambientais tais como hipóxia (Pennel e Lamb 1997, Fagerstedt 2010).

O início do desenvolvimento do aerênquima tem como características principal a $P C D$, que compreende os seguintes processos celulares subsequentes: condensação da cromatina, fragmentação de DNA e formação de corpos de membranas que circundam as organelas (Reed 2000, Gunawardena et al. 2001a). Foram observados sinais de degradação do núcleo celular durante a morte do córtex das raízes, e estes se iniciam do exterior do córtex e avançam em 
direção ao estelo (Henry e Deacon 1981), na mesma direção em que os espaços de ar são formados no córtex.

Durante a PCD, a sinalização por etileno é acompanhada por um aumento citosólico de $\mathrm{Ca}^{2+}$ com posterior acidificação do citoplasma, elementos estes requeridos para que se inicie a morte de células corticais de raízes (Morgan e Drew 2004). Corroborando essa informação, em arroz foi observado que há um acidificação no pH citoplasmático, que se inicia em células isoladas especificas do córtex médio antes de formar o aerênquima (Kawai et al. 1998). Esta sinalização é semelhante àquela que ocorre quando há a formação dos elementos traqueais (Morgan e Drew 2004).

A concentração de $\mathrm{Ca}^{2+}$ citosólico livre é frequentemente mantida entre 100 a $200 \mathrm{nM}$ (Bush 1995). Porém, essa concentração pode aumentar por causa da afinidade do $\mathrm{Ca}^{2+}$ à algumas proteínas, como por exemplo, as calmodulinas (Sanders et al. 1999). O reticulo endoplasmático, a parede celular, as mitocôndrias, vacúolos e os cloroplastos têm a capacidade de sequestrar e armazenar o $\mathrm{Ca}^{2}$ em uma escala de milimol, o que é muito maior do que a concentração no citosol (Bush 1995, Trewavas e Malho 1998). Em células animais, os processos de sinalização via $\mathrm{Ca}^{2+}$ são melhor estudados. Nestes, as mitocôndrias desempenham um papel central na cascata de morte celular, integrando alterações metabólicas (queda no $\mathrm{pH}$, aumento da concentração de $\mathrm{Ca}^{2+} \mathrm{e}$ alterações no estado energético) com a PCD. Em seguida observa-se um aumento da permeabilidade da membrana mitocondrial liberando o citocromo $c$ e um fator de indução de apoptose que conduz à ativação de caspases ou cisteíno-proteases (Fortes et al. 2001, Virolainen et al. 2002). Em experimentos com trigo, foi observada a abertura do poro mitocondrial e liberação do citocromo $c$ apenas nas células com falta de oxigênio e que foram circundadas por altas concentrações de $\mathrm{Ca}^{2+}$, reforçando a participação do cálcio na sinalização para a PCD observado em células animais (Fortes et al. 2001, Virolainen et al. 2002).

Como o processo de PCD que precede formação do aerênquima tem muitas características em comum com a PCD dos elementos traqueais, sugere-se que uma variedade de enzimas hidrolíticas estejam envolvidas em ambos os processos (Morgan e Drew 2004). Embora haja a 
determinação das características morfológicas do aerênquima em diversas plantas, a sinalização que leva ao ataque à parede celular é pouco conhecida. Acredita-se que após o colapso interno das células, observado em microscopia eletrônica de transmissão por Campbell e Drew (1983), a perda da integridade do tonoplasto permitiria o acesso das enzimas que estão nos vacúolos e no citoplasma. Com este evento, a dissolução da membrana celular poderia estar completa dentro de 24 horas que é quando se observam células individuais iniciando a morte celular (Evans 2003).

\section{Modificações que ocorrem na parede celular durante a formação do aerênquima}

As paredes celulares fornecem características importantes para as plantas, pois são elas que desempenham um conjunto de funções essenciais, como por exemplo, o formato diferencial entre as células necessário para formar tecidos e órgãos. Por formarem a interface entre células adjacentes, paredes celulares muitas vezes desempenham papéis importantes na comunicação intercelular e pela localização periférica desempenham um papel importante nas interações plantamicrorganismos, incluindo respostas de defesa contra agentes patogênicos (Kegstra 2010).

Como a formação do aerênquima geralmente é induzida por alagamento (estresse), alguns trabalhos indicam um aumento nas proteínas relacionadas a doenças/resistência e a modificação da parede celular como $\beta-1,3$ glucanase, 1,4 glucano proteína sintase, $\beta$-glucosidase e metionina sintase, e que estas enzimas podem estar relacionadas com as modificações estruturais observadas em raízes de soja (Kong et al. 2010). Entretanto, em estudos com plantas que possuem capacidade de formação de aerênquima (como o milho), são observadas alterações nas pectinas da parede celular durante a desintegração do córtex radicular em uma fase muito precoce da morte celular (Gunawardena et al. 2001b).

Além das mudanças no conteúdo de pectinas (Gunawardena et al. 2001b), muito pouco tem sido descrito sobre as glicosil hidrolases de parede celular. Alguns estudos focam na regulação molecular da formação do aerênquima e a identidade das enzimas envolvidas no processo de PCD (Subbaiah e Sachs 2003). No trabalho de He et al. (1996a) foi reportado que a atividade da enzima celulase é aumentada na região apical antes de qualquer sinal de anormalidade microscópica da 
célula, sugerindo que esta enzima participa da degradação da parede celular durante a formação de aerênquima. Kawase $(1974,1979)$ demonstrou que as células corticais do estame de girassol tratadas com celulase foram ampliadas radialmente, e algumas desintegradas, o que resultou em um espaço intercelular. A expansão celular é dependente de mudanças na parede celular e do crescimento celular radial que ocorre com a indução de celulases que atacam as microfibrilas de celulose (Fan e Maclachlan 1966).

Além da celulase, Saab e Sachs (1996) clonaram um gene cuja expressão foi induzida pelo alagamento e tratamento com etileno, que codifica para uma XTH, enzima relacionadas ao afrouxamento da parede celular. Outras enzimas provavelmente estão envolvidas nesses processos de degradação como as pectinases (Jackson e Armstrong 1999) e também proteínas acessórias sem atividade hidrolítica, como as expansinas.

Leite (2013) caracterizou as modificações que acontecem na parede celular durante a formação do aerênquima em raízes de cana de açúcar, mostrando que o mesmo se inicia com a morte celular programada. Dados deste trabalho mostram que a hidrólise de parede celular não é total, visto que as principais alterações, incluindo degradação, foram observadas para $\beta$-glucano e pectinas (e não dos demais polissacarídeos). A remoção de pectinas, presentes principalmente nas lamelas médias, resultou na separação celular. Também foi observado um aumento proporcional de xiloglucano e arabinoxilano no córtex durante a formação do aerênquima, possivelmente pelo rearranjo da parede celular. No entanto, a ruptura desta estrutura foi observada apenas em algumas regiões específicas. Houve também o colapso da parede celular em algumas regiões onde verificou-se a presença de celulose e xilanos, formando um compósito de parede celular ao redor dos espaços de ar.

Neste contexto, a fim de compreender os mecanismos que levaram às alterações observadas nos polissacarídeos da parede celular das raízes de cana de açúcar durante a formação do aerênquima (observadas por Leite 2013), optou-se neste trabalho por estudar a síntese e a ação das glicosil hidrolases. A hipótese é que haveria uma ação coordenada das glicosil hidrolases, iniciando pelas pectinases que operam as etapas iniciais de separação celular seguidas da síntese 
de glicosil hidrolases que degradam o $\beta$-glucano. Após este processo, supõe-se que haja a produção de glicosil hidrolases que modifiquem as demais hemiceluloses da parede celular. Tendo em vista que a ação das glicosil hidrolases precisa estar em sintonia com a composição e a arquitetura da parede, os pressupostos elaborados neste trabalho levarão em conta os polissacarídeos-alvo e sua acessibilidade na parede celular. Neste contexto, este trabalho vem contribuir com dados referentes às glicosil hidrolases de parede celular produzidas pela cana de açúcar, a fim de que futuramente seja possível transformá-las geneticamente, para que ao longo do desenvolvimento, a parede celular possa ser mais acessível para a sacarificação e geração de energia.

\section{OBJETIVO}

Considerando o conhecimento prévio sobre as alterações na parede celular de cana de açúcar durante o desenvolvimento do aerênquima em raízes de cana-de açúcar, o objetivo deste trabalho foi identificar os padrões de expressão gênica, produção e ação de glicosil hidrolases de suas parede celulares durante o processo de formação de aerênquima.

\section{Objetivos especificos}

- Determinar se a atividade enzimática das hidrolases atuantes na degradação da parede celular durante a formação do aerênquima se é perene ou apresenta uma ordem sequencial;

- Determinar em que fase do desenvolvimento da raiz ocorre a transcrição dos genes e a expressão de proteínas relacionadas às enzimas de degradação da parede celular durante a formação do aerênquima;

- Verificar o grau de acessibilidade de hidrolases aos polissacarídeos da parede celular ao longo dos segmentos. 


\section{MATERIAL E MÉTODOS}

\section{Coleta do material}

Colmos de cana da variedade SP80-3280 foram coletados no sítio Victória na cidade de Piracicaba-SP. Os toletes foram plantados em bandejas contendo vermiculita e, após duas semanas de brotação das gemas e início do desenvolvimento, as plantas foram transferidas para vasos plásticos de 15 litros também contendo vermiculita. A adubação foi feita com NPK (30:20:30) conforme especificações agrícolas para plantio. Passados cerca de 3 meses de cultivo as raízes foram coletadas (Figura 1).

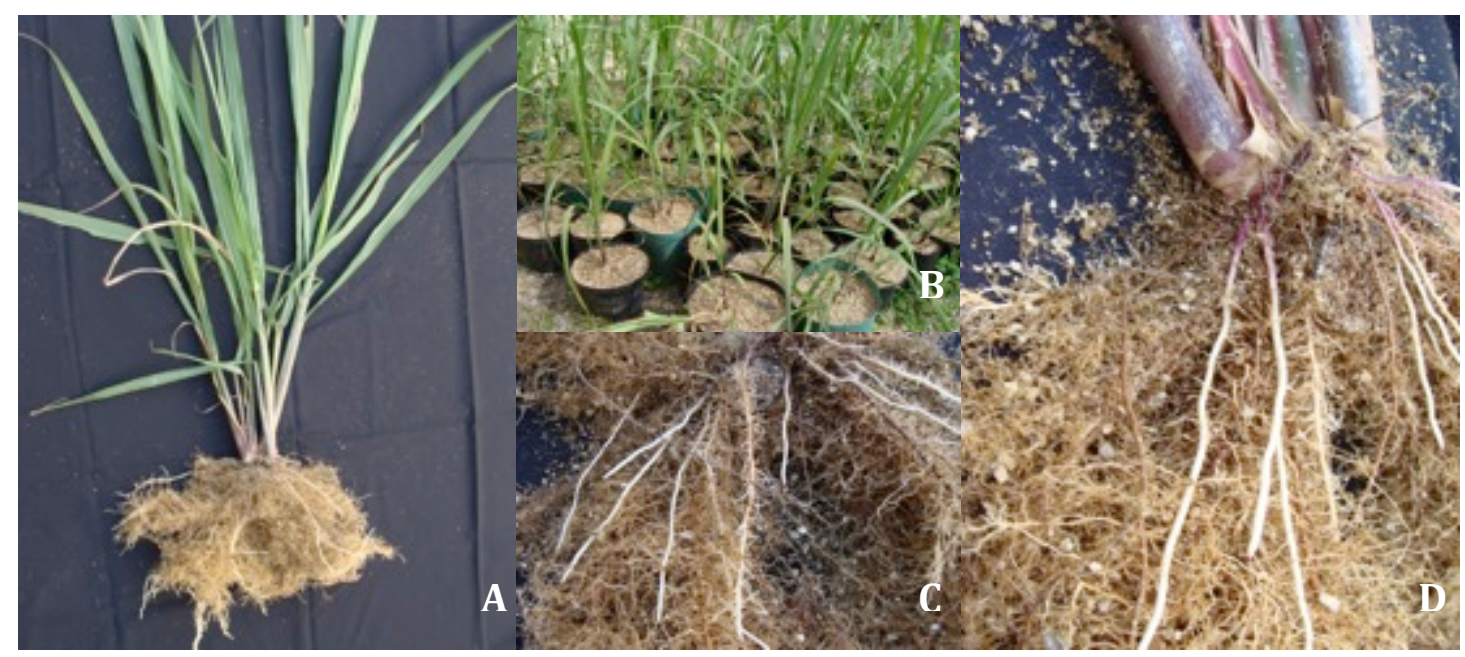

Figura 1. Aspecto geral plantas de cana de açúcar empregadas nas coletas (A-B); Distinção dos dois tipos de raízes adventícias: raízes brancas (raízes do perfilho), mais jovens e túrgidas, empregadas na coleta e raízes marrons (raízes do tolete), mais velhas e lignificadas (C) e detalhe da região de formação da raiz do perfilho (D).

Cinco lotes de plantas foram cultivados conforme descrito acima, sendo destinados às análises de cálculo da formação do aerênquima, quantificação de proteínas totais e análise de proteômica, análise de expressão gênica e material para ensaios de enzimas hidrolíticas. Com o intuito de acompanhar os diferentes estágios de desenvolvimento do aerênquima, os cinco centímetros mais apicais da raiz foram coletados e as secções foram realizadas a cada centímetro, indo do ápice (seg 1) em direção a base (seg 5), conforme mostra a Figura 2. Estes dados foram coletados em conjunto com a dissertação de mestrado da aluna Débora C.C. Leite (2013). 


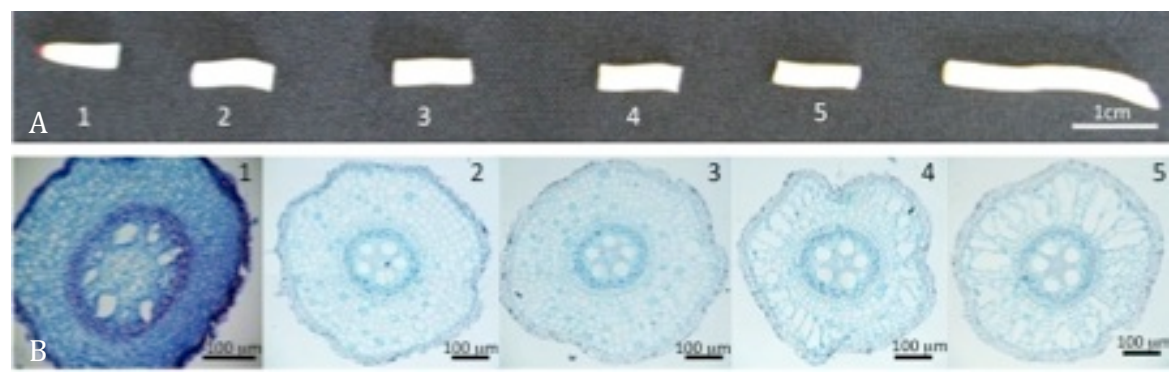

Figura 2. Segmentos sequenciais de $1 \mathrm{~cm}$ das raízes da cana de açúcar do ápice (1) para a base (5) da planta (A); Seções transversais dos segmentos. Barras nas figuras de anatomia representam a escala de $100 \mu \mathrm{m}$ (B) (Fotos: Retirado de Leite 2013).

As coletas foram realizadas sempre entre às 10 e 12 horas, exceto para o experimento de coletas ao longo de $24 \mathrm{~h}$, conforme descrito a seguir. O material coletado foi congelado em nitrogênio líquido e armazenado a $-80^{\circ} \mathrm{C}$ para as futuras análises.

\section{Coleta do Material ao longo de 24 horas}

Considerando os dados apresentados por De Souza (2011) que aponta a síntese mais intensa de compostos da parede celular no período noturno, foi realizada amostragem de segmentos também ao longo de um período de 24 horas. Dessa forma, a transcrição de genes de hidrolases de interesse puderam ser estudadas levando em conta possíveis flutuações temporais ao longo de um ciclo diário.

Em cada horário, cada uma das 5 réplicas foi composta por raízes de 10 plantas (total de 50 plantas por horário). A raízes foram amostradas em 4 horários de coleta ao longo de 24 h (0, 6, 12 e 18h). Após as coletas, os mesmos segmentos que correspondiam a cada horário foram agrupados a fim de contemplar as variações de expressão de transcritos durante 24 horas.

\section{Determinação da proporção de aerênquima entre os segmentos}

Com o intuito de determinar a proporção de aerênquima em cada um dos segmentos, foram amostradas raízes de 6 indivíduos para análises anatômicas nos mesmos dois lotes coletados para análises bioquímicas. Para tanto, cada segmento foi imerso em uma solução de formalina, acido acético e etanol (FAA- $70^{\circ}$ - Johansen, 1940) colocadas no vácuo e estocados a $5^{\circ} \mathrm{C}$ até as 
análises. O material fixado foi desidratado em série etanólica ascendente de 35\%, 50\%, 70\%, 95\% até $100 \%(\mathrm{v} / \mathrm{v})$, durante uma hora e após esta etapa foi infiltrado em historesina conforme instruções do fabricante (Leica Historesin Kit - Jung ${ }^{\circledR}$ ). Secções anatômicas das raízes foram obtidas com espessura de seis a nove milímetros utilizando um micrótomo semi-automático (Leica RM 2145) e foram coradas com o corante Azul de Toluidina (0.025\%), pH 4.0 (Vidal, 1977) e posteriormente montados para análise em microscopia de luz (OLYMPUS BX51).

\section{Análises de expressão gênica}

\section{Desenho dos oligonucleotídeos específicos}

O banco de ESTs de cana de açúcar, (SUCEST -http://sucest-fun.org/; Vettore et al., 2001) foi empregado na busca de clusters de sequencias expressas na raiz (banco root tip, RT) e categorizados por Lima et al. (2001) como referentes à síntese e degradação de parede celular . Tais clusters foram empregados em alinhamentos locais (BLAST - http://blast.ncbi.nlm.nih.gov/) e triagem de sequencias para desenho de iniciadores, o qual se deu por meio da busca de referências quanto à caracterização funcional da proteína correspondente. Assim, de 121 sequencias inicialmente selecionadas, após a triagem empregamos 53 para o desenho de iniciadores.

Após a obtenção das sequências de glicosil hidrolases, as mesmas foram analisadas pelo software Repeatmasker (http://www.repeatmasker.org/) com o intuito de encontrar regiões repetitivas intercaladas no genoma e/ou de baixa complexidade (repetições em tandem, sequencias de polipurinas, regiões ricas em AT) a fim de mascará-las com a letra $\mathrm{N}$ para não interferir na confecção do iniciador.

Após este refinamento e com as sequencias em modelo FASTA, foram desenhados 61 pares de oligonucleotídeos específicos (primers) para o emprego em PCR em tempo real (Anexo 1).

Para desenho dos iniciadores foram utilizadas as ferramentas online Primer 3 (http://frodo.wi.mit.edu/primer3/) e IDT OligoAnalyzer (www.idtdna.com/calc/analyzer) com 
temperatura de melting entre 58 e $60^{\circ} \mathrm{C}$, conteúdo de GC de 40 a $60 \%$, e amplicon com extensão de 50 a $150 \mathrm{pb}$.

Os iniciadores foram sintetizados pela Invitrogen ${ }^{\circledR}$ e ressuspendidos em uma concentração estoque de $100 \mu \mathrm{M}$ em tampão TE (Tris-HCl $10 \mathrm{mM}$; EDTA $1 \mathrm{mM} \mathrm{pH} \mathrm{8,0).} \mathrm{Estes} \mathrm{foram} \mathrm{então}$ aliquotados em uma concentração de $10 \mu \mathrm{M}$ e armazenados a $-20^{\circ} \mathrm{C}$ para testes de eficiência na amplificação.

Na Tabela 1 são apresentados as 26 sequências de iniciadores específicos, bem como os parâmetros de temperatura de melting, homo e hetero dímeros de cada sequência.

Após a síntese, os oligonucleotídeos específicos foram analisados quanto a à eficiência seguindo parâmetros descritos por Hellemans et al. (2007). Iniciadores com eficiência entre 90 e 110\% e capazes de gerar um produto único segundo o padrão observado em curvas de dissociação, foram empregados nas análises por qPCR.

Extração de RNA

A extração de RNA de 200 mg de segmentos de raiz macerados em $\mathrm{N}_{2}$ líquido foi realizada com o método fenol/isotiocianato de guanidina utilizando reagente TRIzol ${ }^{\circ}$ (Invitrogen ${ }^{\circ}$ ), seguindo instruções do fabricante.

O material contendo o RNA extraído foi ressuspendido em $30 \mu \mathrm{L}$ de água e mantido a $-20^{\circ} \mathrm{C}$, para as posteriores análises. 
Tabela 1. Oligonucleotídeos específicos de genes que codificam para enzimas hidrolíticas de parede celular e proteínas acessórias e suas respectivas especificações para a construção.

\begin{tabular}{|c|c|c|c|c|c|c|c|}
\hline nome primer & EST & Sucest-anotação & Blast - ncbi anotação & Espécie & Similaridade (\%) & sequencia do iniciador (FWD) & sequencia do iniciador (REV) \\
\hline a-galactosidase & SCQSRT2034G08.g & alfa galactosidase & alpha-galactosidase & Oryza sativa Japonica & 88 & TCCCCATTCACACAGCGAGA & ACACGGACATGCAGCCAAAA \\
\hline a-xilosidase & SCJLRT1020A08.g & alfa xilosidase & alpha-glucosidase (LOC101761758) & Setaria italica & 93 & GAGCTCTGCAGTCGCTGGAT & CACCAGCTCCCACAGGTACA \\
\hline arabinofuranosida & SCQSRT1034D03.g & arabinosidase & alpha-L-arabinofuranosidase 1-like (LOC102716270) & Oryza brachyantha & 86 & GGAACGCTGCTACCCTTGGA & GGCCAAGACGCGAACTGTCT \\
\hline b-1,3 glucanase1 & SCJLRT1023E06.g & beta 1 3glucanase & beta-1,3-glucanase A (GluA1) & Saccharum hybrid cv & 96 & AGCGCGTCGAAGAGGTTCTG & CCGCTGCTCTGCAACGTCTA \\
\hline b-1,3 glucanase 2 & SCCCRT2004C04.g & beta 1-3 glucanase & beta-1,3-glucanase A (GluA1) & Saccharum hybrid cv & 98 & CGCGTCGAAGAGGTTCTGGT & TCAGCTACGCGCTCTTCACG \\
\hline B-glu 14a & SCVPRT2073A02.g & beta glicosidase/exoglucanase & exoglucanase1 (exg1) & Zea mays & 89 & CCTGCTAGCGTTGGGGAGAG & AGTCACCATGGAGGCCCAAG \\
\hline b-xilosidase & SCCCRT1002G03.g & beta xilosidase & beta-D-xylosidase 6-like (LOC101755206) & Setaria italica & 92 & GCCACGGCATCACAATCAGA & ACGTACCAGCCGCCTTTCAA \\
\hline b-galactosidase & SCEPRT2044F09.g & betagalactosidase & beta-galactosidase (LOC100279948) & Zea mays & 97 & CGGCCCTCGAAGTCGTACTG & CCGGCTCCATCCACTATCCA \\
\hline Calcineurin & SCCCLB1004G05.g & calcineurina b like & calcineurin subunit B (LOC100285425) & Zea mays & 89 & TCGCAGCAGGAGATCGTGTC & TGAGGGAGAACTCGGGGATG \\
\hline Calmodulina & SCCCLR2003G10.g & Calmodulina & calmodulin-like protein 1 (LOC100283599) & Zea mays & 85 & CCTTCCCAGCCAAGCATCAC & GCGGTCGCGGTAGATTAGATAGATG \\
\hline celulase & SCEQRT1024F11.g & celulase & cellulase (Cel3) mRNA & Zea mays & 98 & GAGTTCGCCGACAAGTACCG & GAGGAGCTCGTCGTGGTAGC \\
\hline celulose sintase & SCQGRT1044A07.g & celulose sintase & cellulose synthase-like protein & Oryza sativa & 91 & GTCCACATGACCAGCGATGC & TCTTGGGCTGGGAGTTCGTC \\
\hline expansina & SCQSRT1036C01.g & expansina & expansin-B2-like (LOC102706412) & Oryza brachyantha & 85 & GTTGGCGTACTCCACCAGCA & CGGGGGCTCACTGTCAACTT \\
\hline expansina2 & SCVPRT2077B02.g & expansina & beta-expansin 4 (LOC100281892) & Zea mays & 93 & CAGCGTCCCTTCTCGTCGAT & CACATCCCTTGCCTCCCTTG \\
\hline expansina3 & SCRURT2011A12.g & expansina & expansin-A22-like (LOC101783155) & Setaria italica & 87 & CTGCGGCCAGTGCTACAAGA & AAGTTGGTGGCGGTGATGGT \\
\hline expansina4 & SCVPRT2075H10.g & expansina & alpha-expansin 13 precursor & Zea mays & 98 & CCGGGGAGGCAGTACTTGAG & GATCTGGGGAAGCACGGCTA \\
\hline lacase 1 & SCACSB1039F01.g & lacase & laccase-like & Zea mays & 90 & TGGCCATGGCAATCTCCTCT & CGTGTCACGTTCGCCATTGT \\
\hline lacase 2 & SCCCSD1090D07.g & lacase & laccase-like & Zea mays & 91 & GGTGGAATGCAGACGTGGAG & GGCTGGCCGTTAATGGTGTT \\
\hline pec ac 1 & SCQGAM1045B09.g & pectina acetil esterase & carboxylic ester hydrolase & Zea mays & 91 & TCCCCCAGAACGAGGTGAAA & CTCCTGGCACCAAAATGTTCCTT \\
\hline pec ac2 & SCJLFL3013D11.g & pectina acetil esterase & pectinacetylesterase precursor & Zea mays & 91 & CCGTATCCCTGCAACCCAACT & GGCGAGGTGTGATCCCTCATT \\
\hline endo-poligalact.2 & SCAGRT2038D08.g & pectina methyl esterase & hypothetical protein & Sorghum bicolor & 94 & GCACCAAGCTCCTCCCTGAA & GCCGGGTTACCACTTCCAGA \\
\hline endo-poligalact.1 & SCEZRT2016H09.g & poligalacturonase & polygalacturonase-like & Setaria italica & 83 & CAGCAACGATGTGCAGGTCA & CGTCCCGGACTCGATGGATA \\
\hline XTH3 & SCACSB1036D01.g & xiloglucano endotransglicosidase & xyloglucan endotransglucosylase/hydrolase protein 12-like & Setaria italica & 91 & TGGGCAACAAGGAGATGCAG & ACGCCGTCGATGTACCACAC \\
\hline XTH4 & SCBGLR1023F11.g & xiloglucano endotransglicosidase & xyloglucan endotransglucosylase/hydrolase protein 9-like & Setaria italica & 87 & CGCTGCACAAGAGAGGAGGA & GCCACCACCACCACCATTC \\
\hline XTH1 & SCEQRT2101A02.g & xiloglucano endotransglicosidase & xyloglucan endotransglycosylase/hydrolase protein 8 precursor & Zea mays & 100 & CAACTCCACGCGCAAGTACC & GACGTCAGGTAGAAGGAGGTGACA \\
\hline XTH2 & SCQSRT2034B07.g & xiloglucano endotransglicosidase & xyloglucan endotransglucosylase hydrolase 3 & Bambusa oldhamii & 100 & СTTCTACCTGTCGTCGCAGAACTC & GTCCGGTTGCCCAGGAACT \\
\hline
\end{tabular}


A pureza das amostras foi determinada pela razão da densidade óptica mensuradas em comprimento de onda a 260 e $280 \mathrm{~nm}$. A integridade do RNA foi checada em gel de agarose $(0,8 \%)$ e a quantificação foi realizada a partir da absorbância a 260nm em NanoDrop (ThermoScientific) segundo a fórmula:

$$
[R N A]=\left(A_{260 n m} \times F c \times F d\right) / 1000
$$

onde: Fc é o fator de conversão que indica a equivalência de uma unidade de absorbância no comprimento de onda de $260 \mathrm{~nm}$ correspondente a $40 \mu \mathrm{g}$ RNA. $\mathrm{mL}^{-1}$ e Fd, o fator de diluição da amostra.

Sintese de CDNA para qPCR

Cinco $\mu \mathrm{g}$ do RNA total foram tratados com DNase I Amplification Grade (Life Technologies) seguindo instruções do fabricante. Posteriormente $1 \mu \mathrm{g}$ de RNA tratado foi submetido à síntese de cDNA utilizando o sistema de síntese Multi scribe hight capacity cDNA reverse transcription kit (Life Technologies) de acordo com as instruções do fabricante. O cDNA gerado foi empregado como molde em PCR com o iniciador GADPH (Iskandar et al. 2004) e o produto da amplificação foi analisado em eletroforese em gel de agarose $0,8 \%$ com tampão TAE 1x e posteriormente corado com brometo de etídeo. O mencionado iniciador gera um fragmento de $417 \mathrm{pb}$ a partir de DNA e $183 \mathrm{pb}$ a partir de cDNA.

\section{Análise de expressão gênica por PCR em tempo real}

Antes do início da quantificação dos genes alvo foram realizadas curvas de diluição com todos os iniciadores específicos selecionados para este trabalho utilizando-se um pool de todas as amostras estoque que foram diluídas nas concentrações de 1/5, 1/25 e 1/125, além da solução estoque (sem diluição). Após feita a qPCR foi escolhida a diluição ideal do cDNA para emprego nas reações posteriores, sendo esta de 1/5.

Tanto os testes iniciais das curvas de diluição como as análises da expressão utilizaram o reagente SYBR Green PCR Master Mix (Life Technologies) que foi empregado de acordo com o 
protocolo do fabricante, em $15 \mu \mathrm{L}$ finais. A padronização das condições de amplificação das sequencias-alvo em $25 \mu \mathrm{L}$ de reação foi a seguinte: 10 ng de DNA genômico de cana de açúcar (variedade SP80-3280), 0,2mM dNTPs, 1,25U de GoTaq DNA Polimerase (Promega) e tampão da enzima 1x. Os parâmetros de amplificação consistiram em desnaturação a $94^{\circ} \mathrm{C}$ por 2 minutos, seguido de 40 ciclos de desnaturação a $94^{\circ} \mathrm{C}$ por 1 minuto, anelamento dos iniciadores a $60^{\circ} \mathrm{C}$ por 1 minuto e extensão a $72^{\circ} \mathrm{C}$. Ao final, foi realizado um passo de extensão a $72^{\circ} \mathrm{C}$ por 5 minutos. As reações de qPCR foram feitas em triplicatas experimentais e curvas de dissociação investigaram a presença de amplificações não específicas. Os oligonucleotídeos específicos bem como a anotação da EST e a homologia dada pelo NCBI utilizados para as análises são apresentados na Tabela 2. 0 produto foi analisado por eletroforese em gel de agarose $0,8 \%$ com tampão Tris acetato EDTA (TAE) 1x e posteriormente corado com brometo de etídio.

Os valores de CNRQ (calibrated normalized relative quantity; Hellemans et al. 2007) foram determinados pelo software 2.6 qBasePLUS e os iniciadores de referência foram selecionadas usando a ferramenta GeNormPLUS (Biogazelle, Zwijnaarde, Bélgica; Hellemans et al, 2007). Os normalizadores testados foram gentilmente cedidos pelo laboratório da Profa. Glaucia de Souza (IQ-USP) e selecionados os que se apresentaram mais constantes entre as amostras. Os resultados dos iniciadores deste trabalho estão apresentados como expressão relativa do valor de CNRQ em relação aos normalizadores UB - ubiquitin-conjugating enzyme (SCCCLR1048F12.g), 60S - 60S ribosomal protein (SCJFRZ2009G01.g), GADPH - glyceraldehyde-3-phosphate dehydrogenase (Iskandar et al. 2004), UBE2 - ubiquitin-conjugating enzyme E2 (SCBGLR1002D06.g).

\section{Extração de proteínas totais solúveis e ensaios enzimáticos}

Após a maceração dos segmentos em nitrogênio líquido, foram aliquotados $0,5 \mathrm{~g}$ do macerado ao qual foi adicionado $1 \mathrm{~mL}$ de tampão Mcllvaine pH 5.0 (ácido cítrico e fosfato de sódio) contendo polivinilpirrolidona (PVPP) e fenilmetanosulfonilfluoride (PMSF). Os extratos foram macerados novamente e posteriormente foram centrifugados a 12.000 x g por $30 \mathrm{~min}$ a $5^{\circ} \mathrm{C}$. 
O sobrenadante foi recolhido e o volume final de extrato foi estimado e imediatamente realizados os respectivos ensaios enzimáticos utilizando os substratos sintéticos, conforme a Tabela 2.

Tabela 2. Substratos sintéticos de 4-Nitrophenyl (PNP) e seus respectivos açúcares conjugados, bem como a concentração do substrato durante os ensaios enzimáticos. A possível enzima que degrada cada polissacarídeo está apresentada em descrição.

\begin{tabular}{cccl}
\hline Nomenclatura do substrato & Sigla & $\begin{array}{c}\text { Concentração } \\
\text { do substrato } \\
\text { no ensaio }\end{array}$ & Descrição \\
\hline 4-Nitrophenyl $\boldsymbol{\alpha}$-D-galactopiranoside & a-gal & $25 \mathrm{mM}$ & hidrólise de mananos \\
4-Nitrophenyl $\boldsymbol{\beta}$-D-glucopiranoside & b-glc & $25 \mathrm{mM}$ & hidrólise de celulose \\
4-Nitrophenyl $\boldsymbol{\alpha}$-D-xilopiranoside & a-xil & $25 \mathrm{mM}$ & hidrólise de xiloglucano \\
4-Nitrophenyl $\boldsymbol{\alpha}$-L-arabinofuranoside & a-araf & $10 \mathrm{mM}$ & hidrólise de pectinas (arabinano) \\
4-Nitrophenyl $\boldsymbol{\alpha}$-L-arabinopiranoside & a-arapi & $10 \mathrm{mM}$ & hidrólise de pectinas (arabinano) \\
4-Nitrophenyl $\boldsymbol{\alpha}$-L-fucopiranoside & a-fuc & $25 \mathrm{mM}$ & hidrólise de xiloglucano \\
4-Nitrophenyl $\boldsymbol{\beta}$-D-cellobioside & b-cel & $25 \mathrm{mM}$ & hidrólise de celulose \\
4-Nitrophenyl $\boldsymbol{\beta}$-D-galactopiranoside & b-gal & $25 \mathrm{mM}$ & hidrólise de pectinas (galactanos) \\
4-Nitrophenyl $\boldsymbol{\beta}$-D-glucuronide & b-glr & $25 \mathrm{mM}$ & hidrólise de arabinoxilanos e pectinas \\
\hline 4-Nitrophenyl $\boldsymbol{\beta}$-D-xilopiranoside & b-xil & $25 \mathrm{mM}$ & hidrólise de arabinoxilanos e pectinas \\
\hline 4-Nitrophenyl $\boldsymbol{\beta}-\mathbf{D}$-mannopiranoside & b-man & $10 \mathrm{mM}$ & hidrólise de mananos \\
\hline
\end{tabular}

Os ensaios enzimáticos foram realizados a partir de $50 \mu \mathrm{L}$ de substrato (PNPs na concentração inicial de 50 ou 20 mM) e $50 \mu \mathrm{L}$ do extrato bruto de proteínas totais (concentração final do substrato na Tabela 2). A mistura foi incubada a $40^{\circ} \mathrm{C}$ durante 20 min para os seguintes substratos: a-gal, a-glc, a-araf, a-arapi, b-xil e b-gal (Tabela 2). Para os demais substratos (b-man, bglr, b-cel, a-xil e a-fuc) foi necessária a incubação por uma hora, pois muitas vezes não havia atividade para alguns substratos.

Em seguida foram adicionados $900 \mu \mathrm{L}$ de carbonato de sódio 0,05 M para reagir com o pnitrofenol liberado e interromper a atividade. A leitura do p-nitrofenol foi realizada em espetrofotômetro a 405nm, de acordo com Alcântara et al. (1999).

A atividade enzimática específica foi determinada através da seguinte equação:

\section{$\left[\left[\left[\left[\left[\text { (absorbância/constante) }{ }^{*} \text { VTE }\right]^{*}\right.\right.\right.\right.$ VTEB $] \div$ VEE $\left.] \div \mathrm{t}\right] \div$ PTEB $] 10^{3} \div=\mu \mathrm{mol}$ açúcar.min ${ }^{-1} \cdot \mathrm{mg} \mathrm{proteína}^{-1}$}

Onde, Constante é o coeficiente de extinção molar do PNP-açúcar (14.500); VTE é o volume total de ensaio ( $2 \mathrm{~mL}$ ); VTEB é o volume total de extrato bruto em $\mathrm{mL}$; VEE é o volume de enzima 
utilizada no ensaio $(0,01 \mathrm{~mL})$; $\mathbf{t}$ é o tempo do ensaio enzimático (15 min); TPEB é proteína total (mg) do extrato.

O conteúdo de proteínas totais em cada amostra foi determinado pelo método de Bradford de quantificação de proteínas (Bradford,1976), utilizando como padrão Albumina de Soro Bovino (BSA).

\section{Sacarificação dos segmentos}

A fim de compreender o grau de acessibilidade das enzimas em relação à composição da parede celular, foi realizado o método de sacarificação dos segmentos das raízes de cana de açúcar. Esta análise foi realizada em colaboração com o laboratório do prof. Dr. Leonardo D. Gómez da Universidade de York, Inglaterra. Neste experimento, duas condições de pré-tratamentos foram testadas: $\mathrm{NaOH}$ 0,5 $\mathrm{N}$ (para sacarificar somente a celulose) e água fervente (para sacarificar os componentes de parede celular mais solúveis, como o $\beta$-glucano). Ambos os pré-tratamentos foram realizados à $90^{\circ} \mathrm{C}$ por $30 \mathrm{~min}$.

Após o pré-tratamento, a biomassa foi lavada por mais 6 vezes em $500 \mu \mathrm{L}$ de tampão de acetato de sódio antes das hidrólises enzimáticas. As amostras foram incubadas com agitação a 50 ${ }^{\circ} \mathrm{C}$ na presença do coquetel enzimático (Celluclast - celulase de Trichoderma reesei e Novozyme 188 - celobiase de Aspergillus niger, em um coquetel contendo a proporção de 4:1, respectivamente) como descrito em Gòmez et al. (2010). Após incubação, as reações foram aliquotadas em microplacas e as amostras foram novamente mantidas a $50{ }^{\circ} \mathrm{C}$. Após este período de incubação, a quantificação de açúcares liberados pela sacarificação foi efetuada. Esse procedimento foi realizado automaticamente por uma estação de trabalho robotizada - liquid handling station conforme descrito por Gòmez et al. (2010). 


\section{Análise Proteômica}

\section{Extração de proteínas}

A análise de proteômica foi realizada no Laboratório de Genomica Funzionale e Proteomica dei Sistemi Modello - Departamento di botanica - Univercità di Roma La Sapienza.

Quinhentos mg de macerado em nitrogênio liquido de segmentos de raiz foram empregados nas extrações sequenciais de acordo com os métodos de Borderies et al. (2003) e Feiz et al. (2006) com algumas modificações.

A extração de proteínas foi realizada utilizando o tampão acetato de sódio a 50 mM, pH 6,5 (contendo $1 \mathrm{mM}$ de fenilmetanosulfonilfluoride (PMSF) diluído em etanol 1\%). Nesta extração foi adicionado o coquetel de inibidor de proteases utilizado conforme instruções do fabricante (Sigma Aldrich). Nesta solução foram adicionados diferentes sais a fim de fracionar as proteínas do material. Para tanto utilizamos: $\mathrm{NaCl}$ 0,15 M seguido de $\mathrm{NaCl} 1 \mathrm{M}, \mathrm{CaCl}_{2}$ 0,2 M, EDTA $50 \mathrm{mM}$ e LiCl 3 M. O sal $\mathrm{NaCl}$ foi utilizado para extração de proteínas retidas na parede celular por interações iônicas em duas concentrações para fracionarmos proteínas mais solúveis e mais abundantes das demais. $\mathrm{O} \mathrm{CaCl}_{2}$ é descrito como um sal eficiente na extração de proteínas de parede celular (Smith et al. 1984). O emprego de EDTA nas extrações visa possibilitar a solubilização de proteínas associadas às pectinas, pois é um quelante de cálcio (Selvendram e O’Neil 1987). Já o LiCl foi utilizado a fim de extrair glicoproteínas ricas em hidroxiprolina (Voight 1985) e também proteínas de parede celular.

Proteínas foram extraídas em duas lavagens consecutivas de $500 \mu \mathrm{L}$ cada, totalizando $1 \mathrm{~mL}$ de solução final. Os extratos foram incubados a $5{ }^{\circ} \mathrm{C}$ por 5 min. Em seguida, as amostras foram centrifugadas a $20.000 \times$ g por 30 min a $4{ }^{\circ} \mathrm{C}$ e repetida a extração com a mesma solução.

A fim de manter as mesmas concentrações de proteínas, somente $800 \mu \mathrm{L}$ do extrato foi dialisado em membranas de celulose (Sigma tubing com diâmetro de $6 \mathrm{~mm}$ ) que retêm proteínas maiores que $12.000 \mathrm{Da}$. Os sacos de diálise com cada extrativo foram mantidos em água destilada a $5^{\circ} \mathrm{C}$ durante $16 \mathrm{~h}$ e após este período as amostras foram secas em um concentrador de amostras do 
tipo speed vac. Para quantificação das proteínas totais, o material foi ressuspendido em $40 \mu \mathrm{L}$ de tampão de corrida (Tris $50 \mathrm{mM} \mathrm{pH} \mathrm{6,8} \mathrm{M,} \mathrm{glicerol} \mathrm{8 \% ,} \mathrm{SDS} 20 \%$ e bromofenol $4 \%$ com $\beta$ mercaptoetanol) e as amostras extraídas com o emprego de LiCl e EDTA que foram digeridas em solução (ver abaixo), foram diluídas em $30 \mu \mathrm{L}$ de tampão contendo ureia $6 \mathrm{M}$, tiuréia $2 \mathrm{M}$ e bicarbonato de amônio $50 \mathrm{mM}$. A concentração de proteínas foi obtida utilizando o método de Bradford (1976).

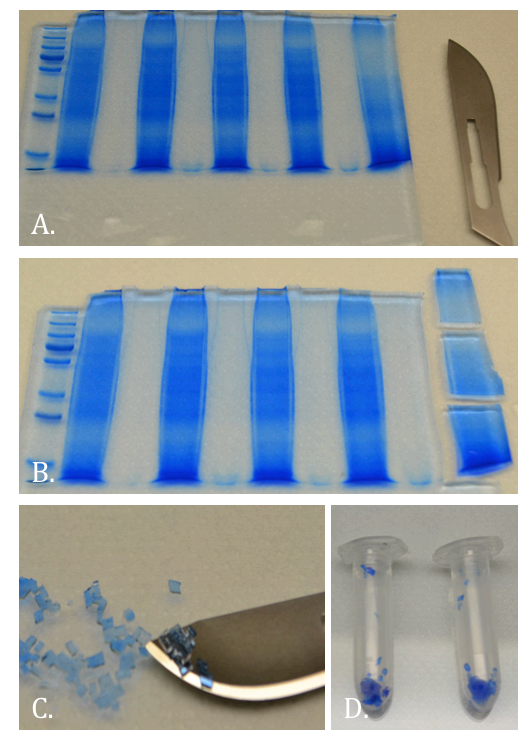

Figura 3. Detalhe da metodologia empregada para fracionar as proteínas para análise proteômica. Gel 1D SDS-Page contendo o padrão de todas as repetições de um segmento (A) e dos cortes realizados entre as repetições a fim de separar ainda mais as proteínas (B). Essas fatias foram cortadas em pedaços menores para digestão (C) e acondicionados em microtubos de $2 \mathrm{~mL}$ (D).

Para fracionamento das proteínas, principalmente as frações que são mais concentradas que outras, em algumas frações de extrativos foram realizados géis de poliacrilamida SDS-PAGE (12\% acrilamida, 0,3\% bis-acrilamida) de acordo com Laemmli (1970). Esses géis foram feitos apenas para as frações de $\mathrm{NaCl} 0,15 \mathrm{M}$ e $1 \mathrm{M}$ e $\mathrm{CaCl}_{2}$ 0,2 M. Após coloração com Colloidal Coomassie pelo método de Neuhoff et al. (1985) os géis foram seccionados nas seguintes bandas de acordo com o padrão de peso molecular específico em cada gel: 1). Para os géis de extratos obtidos com $\mathrm{NaCl}$ 0,1 e $1 \mathrm{M}$, as bandas de cada amostra (contendo $90 \mu \mathrm{g}$ de proteínas) foram cortadas em 3 partes: parte 1 - proteínas com peso molecular entre 250 até $72 \mathrm{kDa}$; parte 2 proteínas entre 72 até $28 \mathrm{kDa}$; e parte 3 proteínas menores que $28 \mathrm{kDa}$. 2) Para os géis de $\mathrm{CaCl}_{2} 0,2$ M (contendo $6 \mu \mathrm{g}$ de proteínas) cada banda foi cortada em 2 partes: parte 1 - proteínas entre 250- 
36 kDa e parte 2 proteínas até 36 kDa. Para evitar contaminação, todos os segmentos de raízes que representavam a mesma réplica experimental foram colocados no mesmo gel, totalizando aproximadamente 20 géis. Frações de $\mathrm{LiCl}$ e EDTA apresentaram baixo rendimento e foram misturadas para serem analisadas juntas (contendo apenas 1,7 $\mu$ g de proteínas) (Figura 3).

\section{Preparo das proteínas para digestão}

Após a determinação da concentração de proteínas nas amostras, foram feitos géis para um maior fracionamento das mesmas (como descrito na Figura 3). Após os cortes dos géis, as amostras foram submetidas ao processo de redução e alquilação das proteínas, e subsequente digestão (frações de $\mathrm{NaCl}$ 0,1 M e $1 \mathrm{M} \mathrm{e} \mathrm{CaCl}_{2}$ 0,2 M). Contudo, para algumas frações que não foram separadas em gel, foi realizado o mesmo processo de redução e alquilação e a digestão foi realizada em solução (EDTA e LiCl), como descrito abaixo.

- $\quad$ preparo de proteínas em gel

Depois da migração de cada amostra de proteínas das frações $\mathrm{NaCl} 0,1 \mathrm{M}$ e $1 \mathrm{M}$ e $\mathrm{CaCl}_{2}$ 0,2 M em gel e da fragmentação do gel em partes menores, que foram cortadas em pedaços menores de $1 \times 1 \mathrm{~mm}$ (Figura $3 \mathrm{c}, \mathrm{d}$ ), foi realizado o processo de branqueamento e desidratação dos pedaços de gel, seguido da redução e alquilação das proteínas presentes em cada amostra pelo protocolo proposto por Shevchenko et al (2006).

Às porções menores de gel foram adicionados $500 \mu \mathrm{L}$ de acetonitrila $100 \%$ seguido de incubação por 10 minutos em temperatura ambiente para desidratação de descoloração. A acetronitrila foi removida e foram adicionados $150 \mu \mathrm{L}$ da solução de DTT 10 mM Dithiothreitol, diluído em bicarbonato de amônio $100 \mathrm{mM}$ e incubados a $56{ }^{\circ} \mathrm{C}$ por $30 \mathrm{~min}$. O DTT quebra as ligações dissulfeto entre as cisteínas que subsequentemente são alquiladas com a adição de iodoacetamida.

Após resfriamento, foram adicionados $500 \mu \mathrm{L}$ de acetonitrila $100 \%$ e as amostras foram incubadas por 10 minutos em temperatura ambiente. A parte líquida foi removida e posteriormente foram adicionados $80 \mu \mathrm{L}$ da solução de IAA (lodoacetamida 55 mM diluída em 
bicarbonato de amônio $100 \mathrm{mM}$ ). As amostras foram incubadas em temperatura ambiente e no escuro por $20 \mathrm{~min}$. Depois desse período, foram adicionados novamente $500 \mu \mathrm{L}$ de acetonitrila $100 \%$. As amostras foram agitadas e em seguida a todas as soluções foram removidas do gel.

A coloração do gel foi removida com $100 \mu \mathrm{L}$ da solução de bicarbonato de amônio 100 mM com acetonitrila $100 \%(\mathrm{v} / \mathrm{v})$ mantendo as amostras por $30 \mathrm{~min}$ em temperatura ambiente. Para finalizar o processo foram re-adicionados $500 \mu \mathrm{L}$ de acetonitrila $100 \%$ e quando o gel estava bem descolorido foi removido todo o líquido do gel. Neste estágio as amostras foram congeladas para posterior digestão.

- Preparo das proteínas em solução

No primeiro passo, as amostras foram diluídas em $40 \mu \mathrm{L}$ de $6 \mathrm{M}$ de uréia, $2 \mathrm{M}$ tiuréia e de bicarbonato de amônio 50 mM pH 8,0. Foi adicionado $1 \mu \mathrm{L}$ da solução de DTT (10 mM Dithiothreitol em agua destilada) e as amostras foram incubadas a $56{ }^{\circ} \mathrm{C}$ por $30 \mathrm{~min}$. Foi adicionado $1 \mu \mathrm{L}$ de IAA (iodoacetamida $50 \mathrm{mM}$ diluída em bicarbonato de amônio $50 \mathrm{mM}$ ). A mistura foi incubada por 20 min no escuro em temperatura ambiente. A redução e a alquilação foram necessárias para manter as proteínas mais lineares (cadeia primária) para que a tripsina pudesse agir efetivamente. Depois desse processo, as proteínas foram digeridas (Shevchenko et al. 1996, modificado).

\section{Digestão das proteínas totais}

Depois da redução e alquilação, as proteínas foram submetidas à digestão com tripsina (trypsin grade modified - PROMEGA) diluída em bicarbonato de amônio $10 \mathrm{mM}$ e acetonitrila 10\%. Durante o ensaio enzimático as amostras foram mantidas por $16 \mathrm{~h}$ à $37^{\circ} \mathrm{C}$, com agitação constante. Para as amostras em gel foi utilizada tripsina $13 \mathrm{ng} / \mu \mathrm{L}$ até cobrir toda a superfície do gel (aproximadamente $80 \mu \mathrm{L}$ ) de acordo com o protocolo de Shevchenko et al. (2006). Neste ensaio, a tripsina foi bloqueada adicionando $150 \mu \mathrm{L}$ da solução de acido fórmico $5 \%$ diluído em acetonitrila $100 \%$ (1:2) e incubado por 15 min à $37{ }^{\circ} \mathrm{C}$ sob agitação. Os sobrenadantes contendo todos os peptídeos extraídos do gel foram removidos e secos em concentrador de amostras. As amostras em 
solução foram digeridas com $13 \mathrm{ng} / \mu \mathrm{L}$ de tripsina de acordo com o protocolo modificado de Shevchenko et al. (1996).

Os componentes restantes da digestão (por exemplo: moléculas que contêm aminas primárias e interferem na marcação dos peptídeos) foram retiradas por dessalinização (Shevchenko et al. 2006). Em todas as amostras utilizou-se dois tipos de colunas de cromatografia de fase microreversa com resinas de octadecil C18 - $47 \mathrm{~mm}$ (disk solid phase extraction $3 \mathrm{M}^{\circledR}$ ) e outra Oligo $\mathrm{R}^{\circledR}{ }^{\circledR}$ (Applied Biosystems ${ }^{\circledR}$ - PN 1-9001-05). As amostras foram filtradas de acordo com as especificações do fabricante. O sobrenadante contendo todos os peptídeos foi novamente seco em concentrador de amostras para a marcação com dimetil, descrita abaixo.

\section{Peptídeos Multiplex: marcação dos peptídeos com isótopos de dimetil para a análise de proteômica quantitativa}

Depois da digestão, dessalinização e secagem, as amostras foram submetidas a diferentes marcações a fim de obter uma análise quantitativa de cada proteína entre os segmentos das raízes de cana de açúcar. Para isso foi utilizado o protocolo descrito em Boersema et al. (2009) otimizado para $25 \mu \mathrm{g}$ de proteína que era a quantidade aproximada de proteínas nas amostras.

Os grupos de amostras (contendo segmentos de raiz e os diversos fracionamentos com sais realizados) foram marcados sequencialmente para manter o mesmo padrão na marcação. A marcação do segmento 3 da raiz foi feita em duplicata em um mesmo tubo a fim de evitar diferenças na marcação dos peptídeos. O segmento 3 foi o controle normalizador entre as amostras porque há uma limitação no número de amostras marcadas que são lidas e comparadas por LCMS/MS. Todas as amostras foram ressuspendidas em $100 \mu \mathrm{L}$ of TEAB $100 \mathrm{mM}$ (triethyl ammonium bicarbonate) contendo os grupamentos de aminas primárias livres e em seguida foram ressuspensos os peptídeos.

Foram adicionadas às amostras $4 \mu \mathrm{L}$ de formaldeídos específicos a $4 \%(\mathrm{v} / \mathrm{v})\left(\mathrm{CH}_{2} \mathrm{O}, \mathrm{CD}_{2} \mathrm{O}\right.$ ou

${ }^{13} \mathrm{CD}_{2} \mathrm{O}$ - light, intermediate e heavy, respectivamente) dependendo da intensidade de cada marcador na sua respectiva amostra (Tabela 3 ) as quais foram manual e gentilmente agitadas. 
Adicionou-se $4 \mu \mathrm{L}$ de cianoboroidrito $0,6 \mathrm{M}\left(\mathrm{NaBH}_{3} \mathrm{CN}\right.$ ou $\left.\mathrm{NaBD}_{3} \mathrm{CN}\right)$ dependendo da intensidade da amostra (light, intermediate e heavy) (Tabela 3, Figura 4).

Os tubos foram agitados constantemente em vórtex durante 1 hora em temperatura ambiente. A ação do marcador foi bloqueada com a mudança de $\mathrm{pH}$ pela adição de $16 \mu \mathrm{L}$ de solução de amônia $1 \%$ (v/v) e posterior acidificação adicionando $8 \mu \mathrm{L}$ de acido fórmico $5 \%$ (vol/vol). Esse processo foi realizado em gelo para prevenir o aquecimento das amostras.

As amostras foram agrupadas de acordo com seus marcadores (segmentos 1, 2 e 3, e segmentos 3, 4 e 5) que passaram pelo mesmo processo de dessalinização pelas colunas de C18 e Oligo R3 descritas acima. Depois da dessalinização, as amostras foram novamente secas em concentrador de amostras e ressuspensas em $20 \mu \mathrm{L}$ de ácido fórmico 0,01\% pra início das análises em LC-MS/MS. O resumo de cada parte foi descrito na Figuras 4 e 5.

Tabela 3. Mudança de massas dos peptídeos pela combinação de formaldeído e cianoboroidrito durante a marcação com isótopos de dimetil e suas respectivas intensidades (light, intermediate e heavy) de acordo com cada segmento de raiz (modificado de Boersema et al 2009).

\begin{tabular}{lccc}
\hline & \multicolumn{3}{c}{ Intensidade do marcador dimetil } \\
\hline Label & Light & Intermediate & Heavy \\
Aumento de massa por marcador & $+28.0313 \mathrm{Da}$ & $+32.0564 \mathrm{Da}$. & $+36.0757 \mathrm{Da}$. \\
Isotopo de formaldeído & $\mathrm{CH}_{2} \mathrm{O}$ & $\mathrm{CD}_{2} \mathrm{O}$ & ${ }^{13} \mathrm{CD}_{2} \mathrm{O}$ \\
Isótopo de cianoboroidrito & $\mathrm{NaBH}_{3} \mathrm{CN}$ & $\mathrm{NaBH}_{3} \mathrm{CN}$ & $\mathrm{NaBD}_{3} \mathrm{CN}$ \\
\hline Segmentos das raízes & 1 e 5 & 2 e 4 & 3 \\
\hline \hline
\end{tabular}

A Figura 5 resume as estratégias empregadas para a extração do material e análise de proteômica das raízes de cana de açúcar durante a formação do aerênquima.

O experimento inicial consistiu em 25 amostras divididas em 5 segmentos de raízes (que são os tratamentos a serem comparados) divididos em cinco replicas (A, B, C, D, E).

Todas as amostras foram digeridas e marcadas para análise em espectrometria de massas. Encontrados os peptídeos, foram identificadas as proteínas e quantificadas entre os segmentos de raiz. 


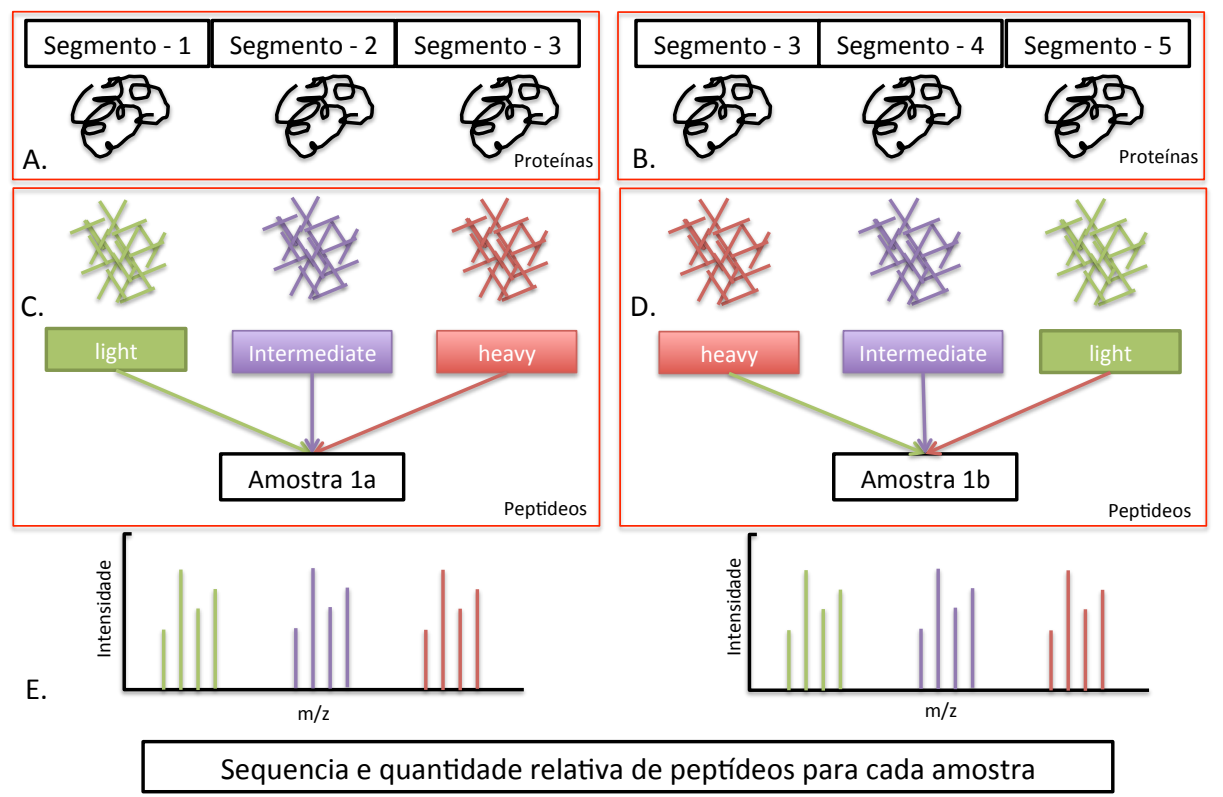

Figura 4. Esquema do desenho experimental que foi conduzido para a extração de proteínas dos segmentos das raízes de cana de açúcar (A e B). Depois da digestão, os peptídeos foram marcados com os componentes de dimetil adicionando diferentes massas aos peptídeos (light, intermediate e heavy) (C e D). Cada amostra foi marcada com diferentes massas e misturadas para análise. Os espectros de massas apresentam a separação por massas das 3 amostras unidas para cada peptídeo, que contribui na separação e quantificação do mesmo em cada amostra. A análise que foi utilizada é a de shotgun por LC-MS/MS (E).

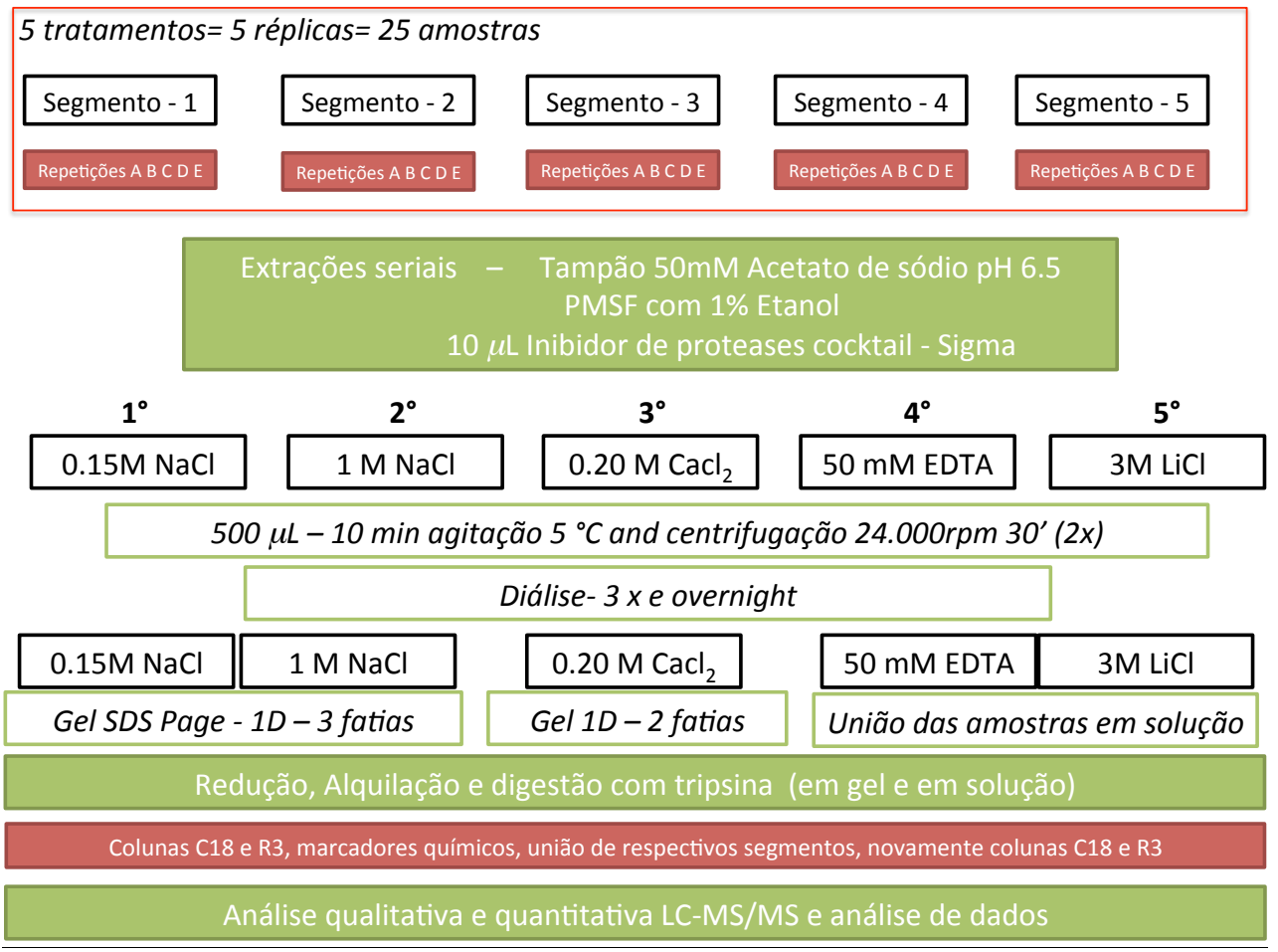

Figura 5. Esquema do experimento que foi realizado com os segmentos de raízes de cana de açúcar para o preparo e fracionamento das amostras para análise por shotgun em LC-MS/MS. 
Identificação e quantificação das proteínas pela fragmentação de peptídeos

A análise de LC-MS/MS dos segmentos das raízes de cana de açúcar foram realizadas em um espectrômetro de massas LTQ-Orbitrap (ThermoScientific) acoplado a uma fonte de íons em nanospray (NS Ion Source, ThermoScientific). A separação dos peptídeos foi realizada utilizando um sistema de cromatografia líquida - Ultimate 3000 nano-LC system (Dionex-ThermoScientific) equipado com uma coluna de RP-HPLC column $(75 \mu \mathrm{m} \times 15 \mathrm{~cm}$ ) empacotada com resina C18 (Magic C18 AQ $3 \mu \mathrm{m}$; Michrom BioResources) utilizando um gradiente linear de 95\% do solvente A (ácido fórmico $0,1 \%$ ) e $5 \%$ do solvente $B$ (de acetonitrila $98 \%$ e ácido fórmico $0,1 \%$ ) para $55 \%$ do solvente B com um tempo de corrida de $160 \mathrm{~min}$ com uma taxa de fluxo de $0,3 \mu \mathrm{L} / \mathrm{min}$. A aquisição de dados foi realizada a fim de obter uma alta resolução com um escaneamento do Mass Spectrometer em Fourier Transformation no espectrômetro de massas em uma resolução em média de 30.000 pela largura máxima ( $\mathrm{m} / \mathrm{z} 400$ ) seguida por eventos de MS/MS em um ion trap linear com os 5 íons mais intensos. O aumento da eficiência nos eventos de MS/MS, foi habilitado para excluir íons não atribuídos e de carga única pela triagem do modo de mudança de carga. A dissociação pela colisão induzida era desencadeada quando o precursor excedia 500 contagens de íons. A duração da exclusão dinâmica foi ajustada para 15 segundos. O tempo de acúmulo de íons foi definido para $300 \mathrm{~ms}$ (MS) e $50 \mathrm{~ms}$ (MS/MS).

Dados no formado. RAW foram exportados diretamente do programa Xcalibur, e a busca de proteínas foi realizada pela plataforma do Maxquant (http://www.maxquant.org/) contra uma base de dados de proteomas preditos pelo banco Uniprot (http://www.uniprot.org/), e utilizando para a montagem das proteínas o banco de dados das ESTs de cana de açúcar (http://sucest-fun.org/).

O critério de busca foi realizado da seguinte forma: 1) total especificidade triptica (clivagem depois de resíduos de lisina e arginina); 2) foram autorizadas clivagens perdidas; como a carbamidometilação de resíduos de cisteína foram definidos como uma modificação fixa; oxidação de metionina foi definido como modificação variável; 3) também foi considerada a marcação com dimetil entre as amostras com as 3 intensidades dos marcadores. A massa tolerante foi de $6 \mathrm{ppm}$ pelo precursor de íons e 0,5 Da por íons fragmentados. A taxa de falsos peptídeos descobertos 
(false discovery rate - FDR) foi de 5\% para o nível de peptídeos e a validação usando o número de hits das sequências de proteínas utilizando a base de dados reversa. Os resultados foram comparados com o banco de dados específico para cana de açúcar, e analisados com o auxílio do software Perseus (http://www.perseus-framework.org/) para a quantificação da abundância das proteínas (Cox e Mann 2008).

\section{Análise de dados}

Dados referentes a atividade enzimática, expressão de genes, sacarificação da biomassa e quantidade de proteínas foram analisados com o auxílio do software JMP 5.0.1 (Copyright@ 1989 2002 SAS Institute Inc.). Foi testado a homogeneidade de variância e em seguida realizado o teste paramétrico Anova - One-way seguido do teste a posteriori de Tukey, considerando significativo o valor de $\mathrm{P}<0,05$.

Nas análises de dados da proteômica, das 1082 proteínas encontradas em todas as amostras, foi realizado um filtro inicial de valores válidos para cada proteína encontrada ao menos em 3 réplicas experimentais. Após este processo, foi realizado outro filtro normalizando a presença e ausência das proteínas de acordo com o segmento 3 em cada corrida, pois nas corridas havia proteínas que não foram identificadas para a mesma amostra. Para tanto, o segmento 3 foi colocado em dois grupos de amostras para ser o segmento comparativo entre duas corridas no equipamento LC-MS/MS (desenho experimental de marcadores Figura 4). Após essa primeira filtragem, restaram 525 proteínas que foram identificadas e normalizadas.

Destas 525 proteínas consideradas nas análises, foram selecionadas as relacionadas a síntese e degradação da parede celular e as de PCD (morte celular programada). A quantificação relativa destas proteínas foi determinada com base na razão entre os segmentos de raiz subsequente $(1 / 2,2 / 3,3 / 4$ e $4 / 5)$ conforme descrito no desenho experimental realizado (Figura 4). Os termos de ontologia genética para cada sequencia foram obtidos junto ao Blast2GO com a apresentação dos principais termos dos processos biológicos, componente celular e função 
molecular de cada proteína, e quando enzima, comparada junto ao Kegg para obter o E.C. (Enzyme code) e o nome da enzima homóloga.

Para quantificar as proteínas ao longo dos segmentos foi utilizado o software Maxquant, que opera calculando as razões normalizadas entre as intensidades das amostras marcadas referentes as mesmas proteínas identificadas. Para realizar as quantificações relativas entre as razões foram utilizadas as razões normalizadas, calculadas e ajustadas pelo programa entre os segmentos de raiz. A razão foi calculada para os segmentos na seguinte forma: $2 / 1,3 / 2,3 / 4$ e 4/5 (proporção entre a quantificação de uma dada proteína no segmento $\mathrm{n}$ em relação à sua abundância no segmento $n-1)$. Devido ao tipo de marcação escolhida entre as amostras foi necessário que algumas das razões fossem invertidas no sentido de formar um gradiente de razões ao longo da análise, sendo assim as razões $2 / 1$ e $3 / 2$ foram invertidas $(1 / x)$ para que se tornassem equivalentes a $1 / 2$ e 2/3. A análise de dados dessas razões de cada proteína entre os segmentos foi realizada pelo teste paramétrico Anova - One-way considerando significativos valores de $\mathrm{P}<0,05$.

A partir desses dados que foram significativos pelo teste Anova, foi realizada uma outra normalização com o intuito de deixar as razões transformadas para melhor compreender a sua abundância relativa entre os segmentos. Quando negativos, os valores das razões expressam que as proteínas diminuíam ao longo dos segmentos e quando os valores são positivos expressam um aumento nas proteínas ao longo dos segmentos. Para ajustar os valores de forma a poder avaliar as variações ao longo dos 5 segmentos, os dados de razão foram submetidos a seguinte operação: diferença entre segmentos $=(R-1) *-1$. Onde $R$ é a razão entre dois segmentos. Estes dados estão apresentados nas tabelas de proteínas de PCD e de parede celular.

A partir dessas razões normalizadas foi possível analisar os padrões de variação das proteínas em cada segmento de raiz. Para isso foram construídos gráficos representativos, onde foi considerado que o segmento 1 da raiz seria a base relativa de todos os outros dados, sendo este considerado o valor 0 . A partir do segmento 1, havia a informação proporcional dos segmentos (dada pela razão) para cada proteína. Para isso, os dados do segmento 2 eram a os valores correspondentes a razão 1/2, uma vez que 1 era o valor 0 . Para o segmento 3 , foi somado o valor 
do segmento $1 / 2$ e $2 / 3$, que corresponde ao que ocorreu entre os dois segmentos, o valor do segmento 4 foi somado as razões, 1/2,2/3 e 3/4 e o segmento 5 foi realizada a somatória de todos as razões. Desta forma cumulativa foi possível avaliar se as proteínas estavam aumentando de concentração entre segmentos ou se estavam reduzindo a concentração, baseados no segmento 1 (conforme Figura 6).

Foram realizados gráficos de cluster (heatmap) para todas as proteínas encontradas. Todas as análises e gráficos foram construídos com o auxilio do software Perseus (http://www.perseusframework.org/) (Cox e Mann 2008), versão 1.5.0.0. Para a construção do heatmap os dados foram transformados em $\log _{2}$ seguido de Z-score de acordo com as instruções do tutorial de análise proteômica do Perseus.

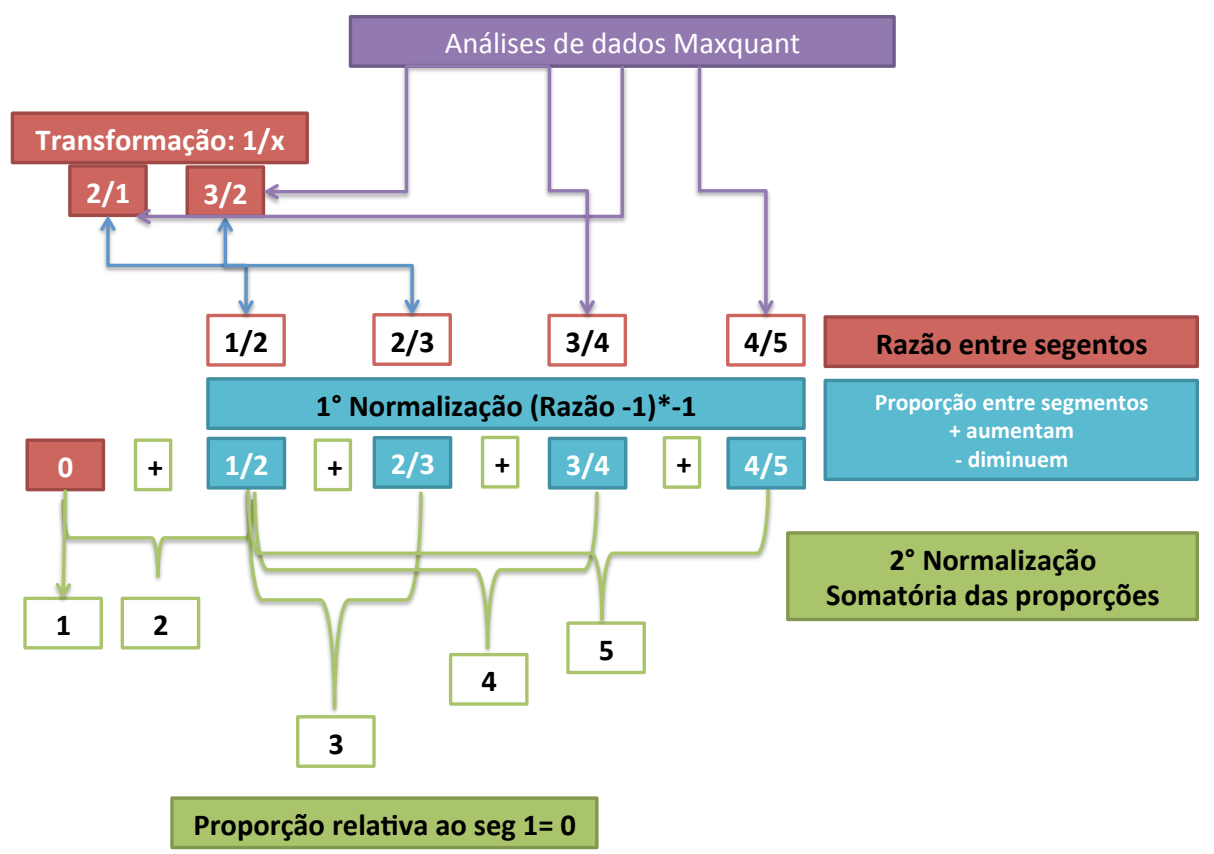

Figura 6. Delineamento experimental utilizado nas análises de proteômica quantitativa a partir das razões normalizadas obtidas pelo software Maxquant.

\section{RESULTADOS}

\section{Determinação da proporção de aerênquima em cada segmentos}

A porcentagem de aerênquima foi determinada entre os segmentos de raízes de cana de açúcar como é mostrado na Figura 7. Pode ser observado que nos segmentos 1 e 2 não há a formação de aerênquima, seguido da presença desta estrutura a partir do segmento 3. A fim de 
minimizar os efeitos da variabilidade ao longo dos segmentos, o número amostral dos cortes foi de 3 a 5 por indivíduo, com réplicas amostrais biológicas compostas de 8 indivíduos coletados em dois lotes de plantas. Foi observado que em raízes de cana de açúcar a porcentagem de aerênquima varia entre $10 \%$ e $30 \%$ nos segmentos 3 a 5.

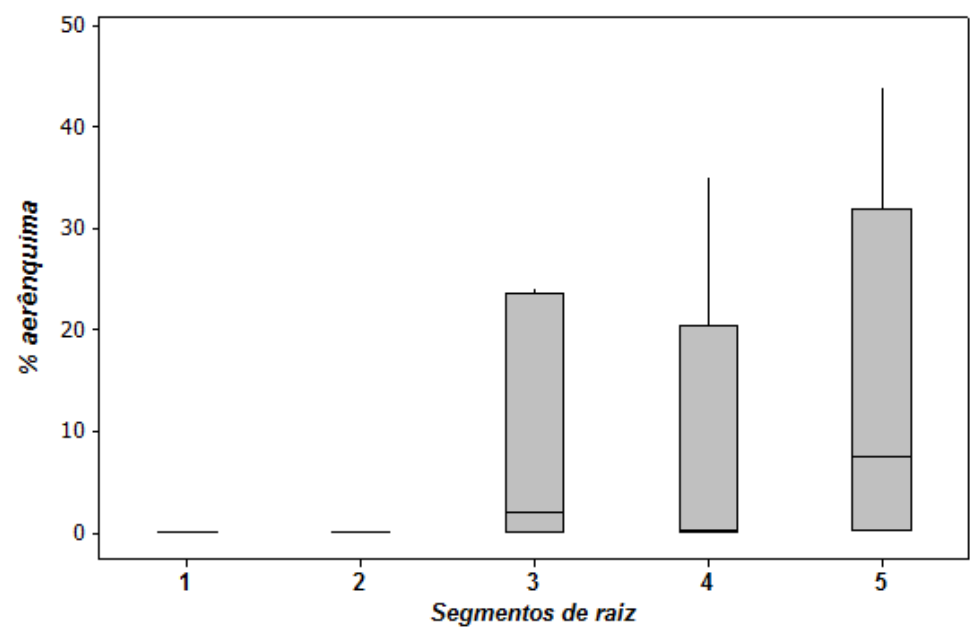

Figura 7. Distribuição dos dados correspondentes a porcentagem de aerênquima (área da secção transversal) no córtex de raízes de cana de açúcar em diferentes segmentos do ápice (1) para a base (5) (n=8).

\section{Proteínas solúveis e identificação das hidrolases de parede celular}

A concentração de proteínas apresentou diferenças significativas apenas no segmento 1 com a maior concentração de proteínas em relação a todos os outros segmentos $(P<0,0001)$, conforme observado na Figura 8.

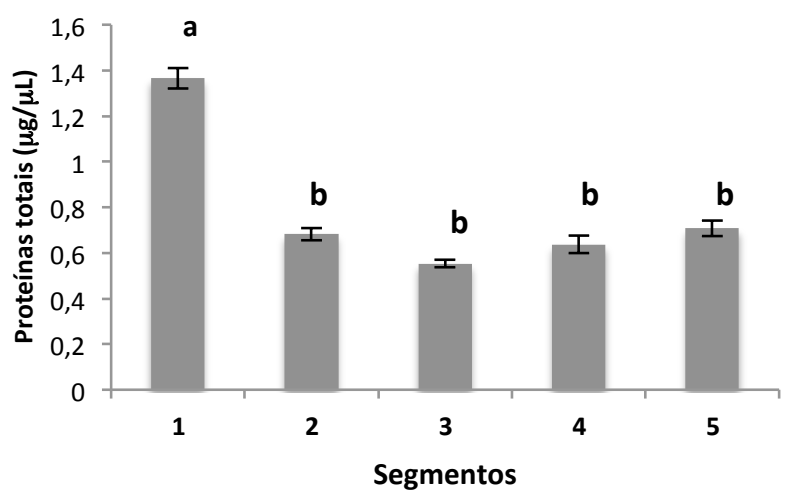

Figura 8. Proteínas solúveis totais extraídas com tampão Mcllvaine $(\mathrm{pH} 5,0)$ para análise da atividade enzimática dos segmentos (1 a 5) das raízes de cana de açúcar. Barras representam a média aritmética \pm erro padrão da média $(n=5)$ e letras representam diferença significativa entre a quantidade de proteínas dos segmentos pelo teste de Tukey $(P<0.05)$. 
Para os ensaios enzimáticos foram utilizados substratos sintéticos que são apresentados na Tabela 2. A maioria dos substratos utilizados é para exo-enzimas, pois o 4-nitrofenol (composto que reage com o carbonato de cálcio em meio alcalino e resulta na coloração a ser quantificada a 405 $\mathrm{nm}$ ) é ligado a uma molécula de monossacarídeo, formando uma ligação glicosídica clivável por exo-hidrolases. Como o reconhecimento se dá através do açúcar, a clivagem indica a ação específica da hidrolase sobre monossacarídeos presentes nos terminais não redutores de poli e oligossacarídeos.

Neste trabalho foram feitas tentativas de incubar os extratos enzimáticos dos segmentos com polissacarídeos com o objetivo de verificar a ação de endo-enzimas sobre arabinoxilano, galactomanano e xiloglucano. No entanto, em nenhum dos ensaios se verificou qualquer indício de ação enzimática e por isto tais resultados não são mostrados.

No entanto, um substrato que pode indicar atividade de endo-enzima sobre fragmentos de celulose é o B-CEL ( $\beta$-celobiose). Este substrato possui mais de um açúcar ligado pelo carbono 4 à molécula de 4-nitrofenil (duas glicoses $\beta-1,4$ ligadas) que pode ser utilizada para testar a presença de possíveis celobiohidrolases (exo- $\beta-1-4$ glucanase) ou endo- $\beta$-1,4-glucanases. 0 resultado demonstrou a presença de atividade de celulase no ensaio com o extrato de raiz para este substrato (Figura 10). Além da celulase, outras enzimas podem estar atuando na hidrólise sobre o substrato B-CEL, notadamente xiloglucanases e mananases que podem reconhecer a ligação $\beta$-1-4 entre duas glucoses. A atividade B-CEL específica coincidiu com a atividade sobre B-GLC, o que parece realmente indicar atividades complementares de hidrolases sobre oligossacarídeos oriundos da celulose.

A presença da atividade de $\alpha$-gal (Figura 10) pode indicar a hidrólise de galactoses ligadas na forma $\alpha$, que possivelmente no tecido estaria associada à hidrólise de polissacarídeos do tipo galactomanano. Porém, em cana de açúcar já foi observado que há uma quantidade muito baixa de manose na parede celular (De Souza et al. 2013). Portanto, uma vez que a ação das $\alpha$ galactosidases solúveis é muito observada no ciclo celular, esta enzima pode estar atuando em outras vias metabólicas, como por exemplo a hidrólise de rafinose. 
Atividades de $\alpha$-arabinosidases (nas formas furanosídicas e piranosídicas) e de $\beta$ galactosidases foram detectadas ao longo dos segmentos da raiz (Figura 9). Esta última, bem como a forma piranosídica da arabinose, apresentaram um padrão de evolução da atividade com elevação ou pico no segmento 3. Nestes casos é possível que haja associação com ramificações neutras de pectinas (arabinanos e galactanos). Já a atividade sobre a forma furanosídica de arabinose só aumentou no segmento 5 , podendo estar relacionada com a desramificação de arabinoxilanos.

Analisados em conjunto, os resultados de atividade indicam que atividade geral de exoglicosil hidrolases e de uma celulase (B-CEL) nos segmentos das raízes de cana, estas aumentam gradativamente até o segmento 3 (Figura 9), segmento este que é o primeiro a apresentar evidências da presença de aerênquima (Figura 7).

\section{Expressão gênica}

Durante o desenvolvimento, além da formação do aerênquima que foi caracterizada como tendo iniciado provavelmente no segmento 3 e progredindo até o segmento 5 (Figura 7), as raízes de cana desenvolvem, ao mesmo tempo, outros processos. Enquanto o meristema apical é responsável pela produção de novas células, apresentando intensa atividade de divisão e expansão celular (segmentos 1 e 2), o desenvolvimento do sistema vascular ocorre principalmente nos segmentos 2 e 3 . Ainda que o foco principal deste trabalho tenha sido a formação do aerênquima e em particular a produção de hidrolases de polissacarídeos, alguns aspectos dos padrões de expressão evidenciaram possíveis correlações com os outros processos mencionados acima.

Transcritos referentes à celulose sintase (SCQGRT1044A07.g) apresentaram o mesmo padrão ao longo dos segmentos (Figura 10), indicando que as células da raiz mantêm a produção de celulose constante em toda a raiz. O perfil de expressão não permite atribuir tal atividade a qualquer um dos processos em curso na raiz (divisões celulares no meristema apical, formação do aerênquima e produção de tecidos vasculares). 


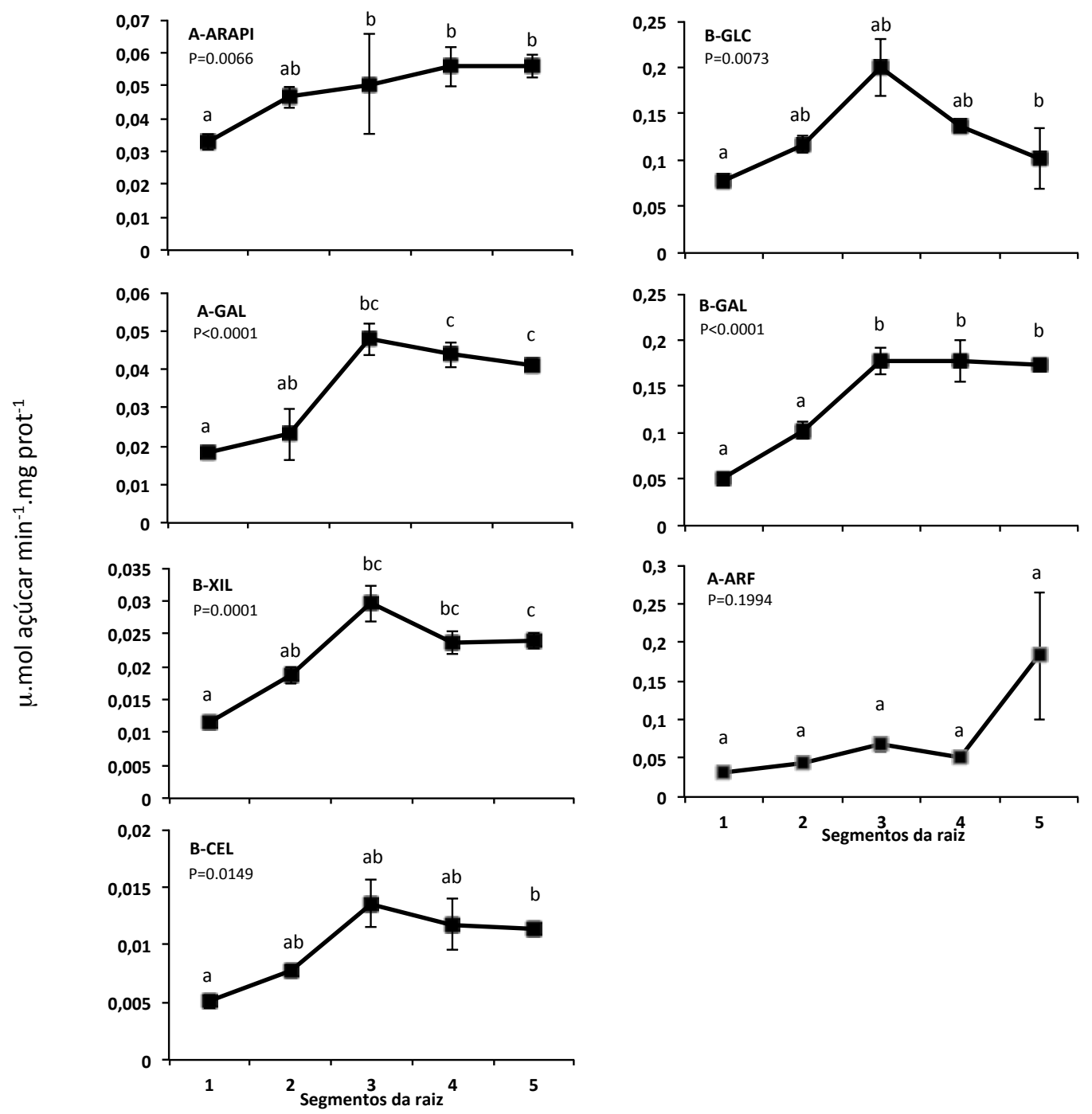

Figura 9. Atividades específicas ( $\mu . \mathrm{mol}$ açúcar $\min ^{-1} \mathrm{mg} \cdot \operatorname{prot}^{-1}$ ) de glicosil hidrolases de parede celular presentes no extrato protéico total de diferentes segmentos de raízes de cana de açúcar empregando substratos de 4-nitrofenil (siglas dos PNPs ver Tabela 2). Barras representam a média \pm erro padrão da média $(n=4)$ letras representam diferença estatisticamente significativa da atividade entre os segmentos pelo teste de Tukey $(P<0,05)$.

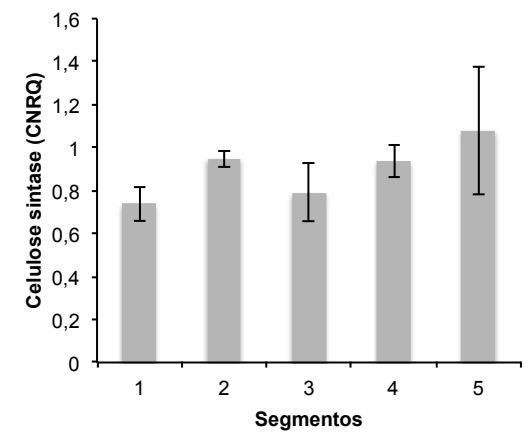

Figura 10. Perfil de expressão diferencial do gene celulose sintase nos segmentos (1 a 5) de raízes de cana de açúcar. Dados representam média e o erro padrão $(n=5)$. Não houve significância pelo teste ANOVA-Tuckey $(P<0,05)$. 
Considerando que o processo de morte celular programada (PCD) ocorre em paralelo à formação do aerênquima, sendo provavelmente evento essencial no processo, alguns dos genes sabidamente relacionados à PCD foram acompanhados no sentido de identificar o estágio em que PCD ocorreu na raiz. Neste sentido, foram analisados os padrões de expressão de dois genes que codificam para proteínas sensoras de $\mathrm{Ca}^{2+}$ que podem indicar o início de $\mathrm{PCD}$ e ter alguma relação com a iniciação (talvez ser um dos primeiros eventos) da formação do aerênquima. Conforme observado na Figura 11, a partir do segmento 2 até o 4 houve um aumento no acúmulo de transcritos referentes ao gene CBL (Calcineurin B Like - SCCCLB1004G05.g), em relação ao segmento

1. Contudo, no segmento 5 o acúmulo é menor, com níveis similares ao observado no segmento 2 .

O perfil transcricional de CAM (calmodulina - SCCCLR2003G10.g) apresentou o mesmo padrão de CBL (Figura 11).
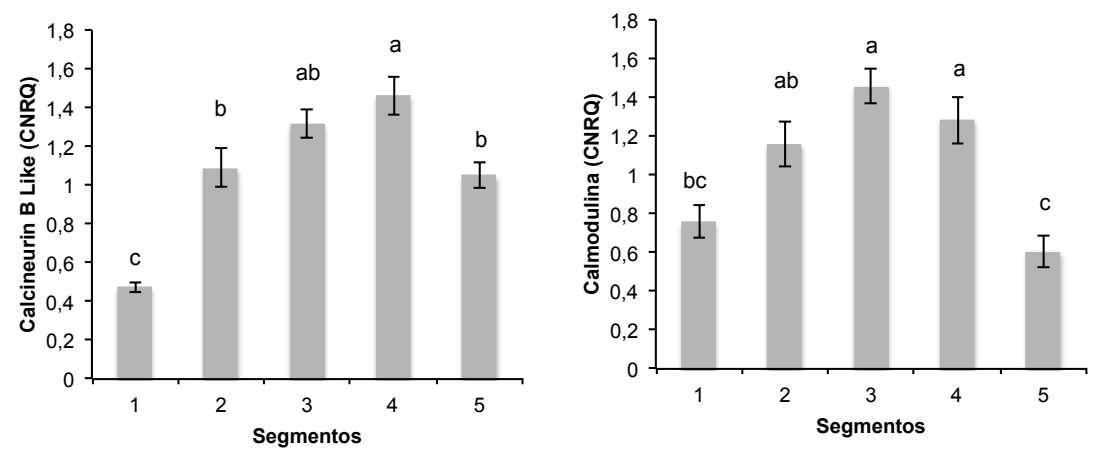

Figura 11. Perfil de expressão diferencial de genes relacionados ao metabolismo de cálcio (Calcineurina e Calreticulina) nos segmentos ( 1 a 5 ) de raízes de cana de açúcar. Dados representam a média e o erro padrão $(n=5)$. Letras diferentes representam significância pelo teste ANOVA-Tuckey $(P<0.05)$.

Visando observar as variações em expressão gênica que pudessem estar relacionadas diretamente à formação do aerênquima, genes associados com a hidrólise de lignina e polissacarídeos foram avaliados nos 5 segmentos isolados.

Os padrões de expressão de genes que codificam para lacases (lacase 1 - SCACSB1039F01.g e lacase 2 - SCCCSD1090D07.g) demonstram aumento no acúmulo de transcritos principalmente no segmento 2 (Figura 12). Lacase 1 apresentou um pico no segmento 2 e posteriormente se manteve constante. Por outro lado, a lacase 2 apresentou um aumento nos níveis do transcrito persistente até os segmentos 2 e 3, decaindo nos segmentos 4 e 5 e atingindo níveis similares aos observados 
no segmento 1 (Figura 12). Isso sugere que a lignina presente no tecido possa ser alvo de hidrólise enzimática.
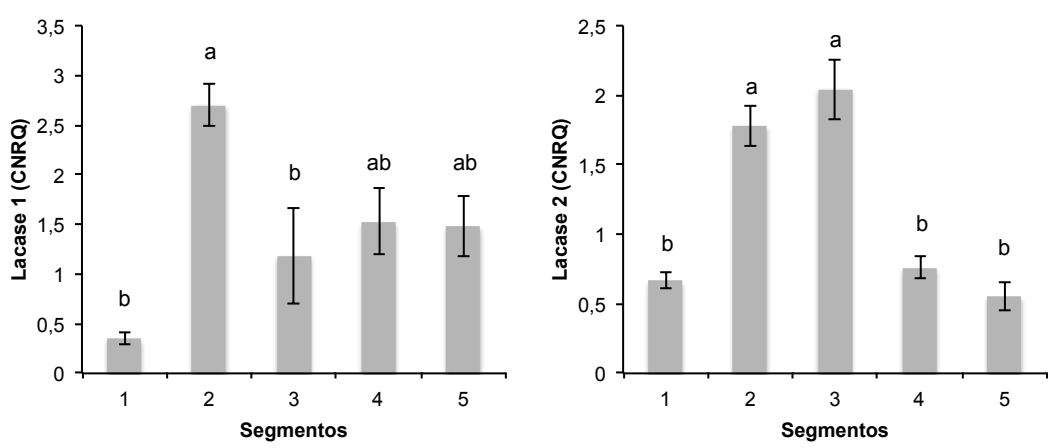

Figura 12. Perfil de expressão diferencial de genes relacionados à hidrólise de lignina (lacases) nos segmentos (1 a 5) de raízes de cana de açúcar. Dados representam média e o erro padrão $(n=5)$. Letras diferentes representam significância pelo teste ANOVA-Tuckey $(P<0.05)$.

No que diz respeito aos transcritos referentes às enzimas que atuam sobre xiloglucano, empregamos quatro pares de iniciadores para amplificação de XTHs, desenhados a partir da sequência de 4 ESTs distintas (XTH1 - SCEQRT2101A02.g, XTH2 - SCQSRT2034B07.g, XTH3 SCBGLR1023F11.g e XTH4 - SCACSB1036D01.g) (Figura 13). A enzima xiloglucano endotransglicosilase/hidrolase (XTH) tem a capacidade de clivar o polissacarídeo (atividade de xiloglucano endo-hidrolase - XEH) ou reagrupar as cadeias de xiloglucano (atividade de xiloglucano endo-transglicosilase - XET). Empregando os iniciadores XTH1 e 2 (ref. aos SAS SCEQRT2101A02.g e SCQSRT2034B07.g) foi observado o mesmo padrão de acúmulo de transcritos, sendo maior e significativo no segmento 1 em relação aos demais (Figura 13). Porém, resultados de alinhamento múltiplo sugerem que estas não se tratam do mesmo gene. Estas duas XTH podem estar relacionadas aos processos de divisão celular e expansão celular, pois no segmento 1 é onde estes processos estão ocorrendo com maior intensidade, pois trata-se da região que contém o meristema apical da raiz. Além disso, estas XTHs poderiam também estar relacionadas à formação do aerênquima, pois nesta etapa de expansão celular é requerida para início das modificações teciduais características deste evento (Kawai et al. 1998).

O emprego dos iniciadores XTH3 demonstraram que o transcrito alvo tem o mesmo padrão ao longo de todos os segmentos não sendo possível atribuir a expressão deste transcrito a eventos específicos na raiz. O perfil de expressão de XTH4 apresentou consonância com a formação do 
aerênquima uma vez que aumentou gradativamente do segmento 2 até o segmento 5 . No entanto, também apresentou alto nível de expressão no segmento 1 (Figura 13).
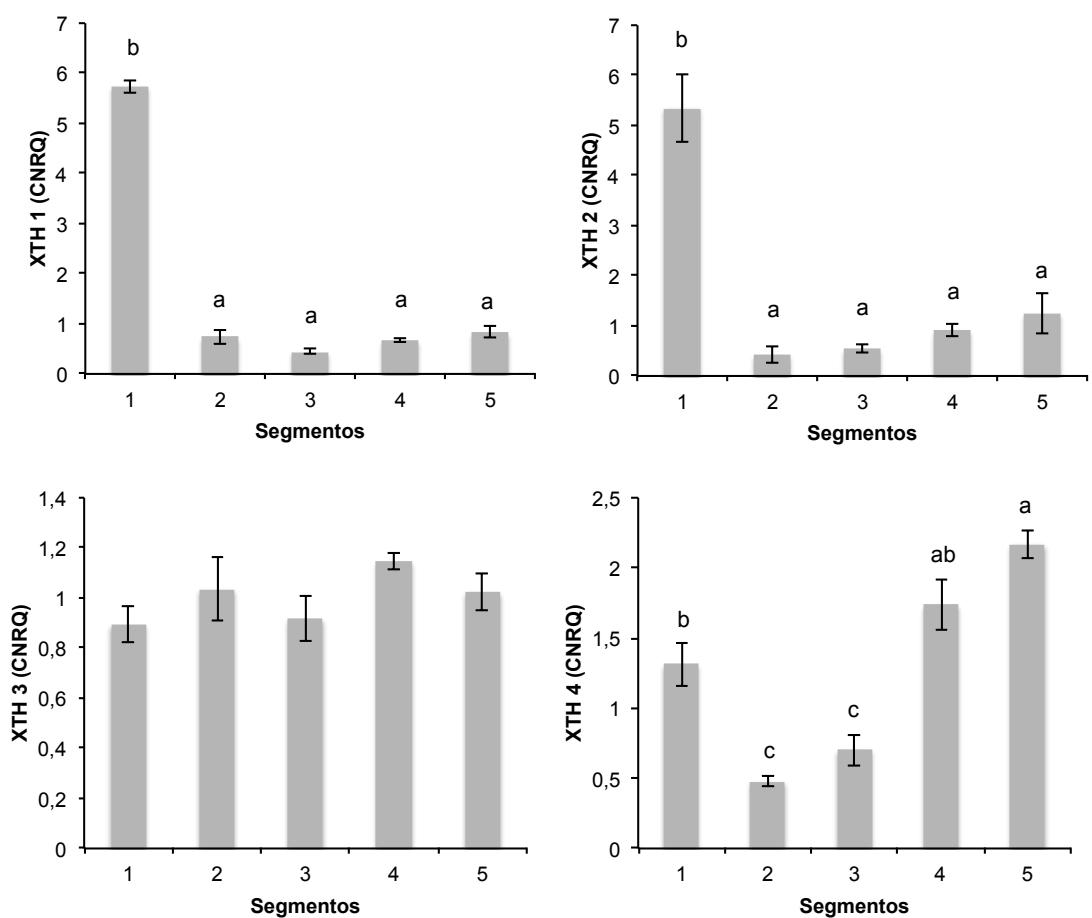

Figura 13. Perfil de expressão diferencial dos genes de xiloglucano endo-transglicosilase/hidrolase (XTH) nos segmentos (1 a 5) de raízes de cana de açúcar. Dados representam média e o erro padrão $(n=5)$. Letras diferentes representam significância pelo teste ANOVA-Tuckey $(P<0,05)$.

Além das XTH e da celulose sintase (Figuras 13 e 10), outra classe de proteínas que participa nos processos de crescimento, relacionada à expansão celular, é a das expansinas (Figura 14). Todos os transcritos referentes a expansinas analisados (EXP1 - SCQSRT1036C01.g; EXP2 SCVPRT2077B02.g; EXP3 - SCRURT2011A12.g; EXP4 - SCVPRT2075H10.g) apresentaram o mesmo padrão ao longo da raiz, com maiores níveis no segmento 1 e 5 . Estas quatro expansinas foram checadas quanto a sua similaridade entre si e os resultados de alinhamento múltiplo sugerem que não se tratam do mesmo gene. Os padrões de variação de EXP1 e EXP2 são similares ao padrão observado, por exemplo, para XTH4 (Figura 13), com alta expressão no segmento 1 e expressão crescente entre os segmentos 2 e 5 (Figura 14). Já os genes EXP3 e EXP4 apresentaram um padrão ligeiramente distinto, com um decrescimento a partir do segmento 1 até o 4 e um aumento no segmento 5 (Figura 14). 

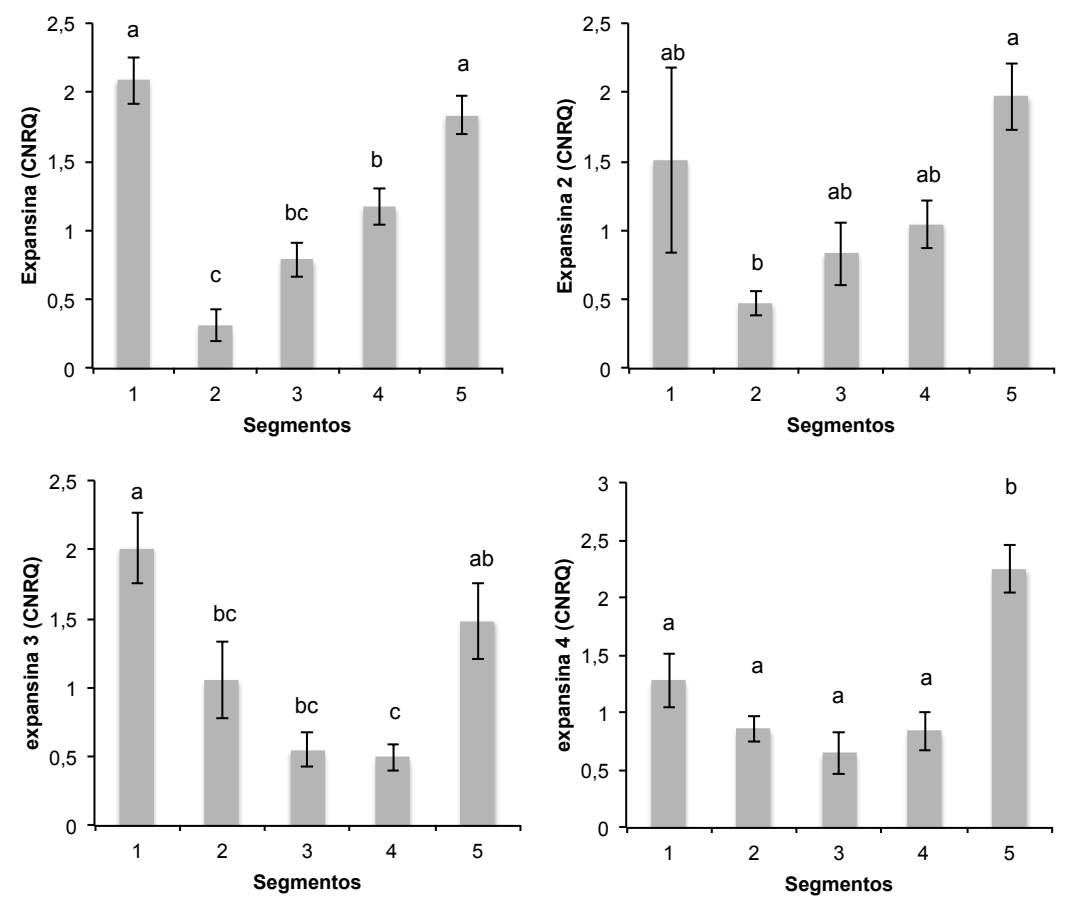

Figura 14. Perfil de expressão diferencial dos genes que codificam para expansinas nos segmentos (1 a 5$)$ de raízes de cana de açúcar. Dados representam média e o erro padrão $(n=5)$. Letras diferentes representam significância pelo teste ANOVA-Tuckey $(P<0,05)$.

A transcrição de enzimas que atacam as pectinas foi avaliado através de medidas de expressão dos genes correspondentes a duas endo-poligalacturonases (EPG1 - SCEZRT2016H09.g e EPG2 - SCAGRT2038D08.g). Estes genes apresentaram padrões distintos de expressão entre os segmentos, embora (Figura 15). Enquanto EPG1 apresentou níveis crescentes em direção ao segmento 5, o PG2 acumulou-se nos segmentos 2 e 3, reduzindo seus níveis nos segmentos subsequentes.

Para os transcritos correspondentes às outras pectinases, sequências estas na sua maioria anotadas como pectinas acetil esterases (iniciadores pec ac 1 e 2, desenhados com base nas ESTs SCQGAM1045B09.g e SCJLFL3013D11.g) houve uma tendência geral nessas hidrolases de pectina serem maiores a partir do segmento 2 (Figura 15). Os resultados para a expressão gênica das hidrolases que atacam as pectinas (endo-poligalacturanases e pectinas acetil esterases) sugerem que as pectinas são inicialmente desacetiladas anteriormente ao ataque pelas endo-hidrolases. 

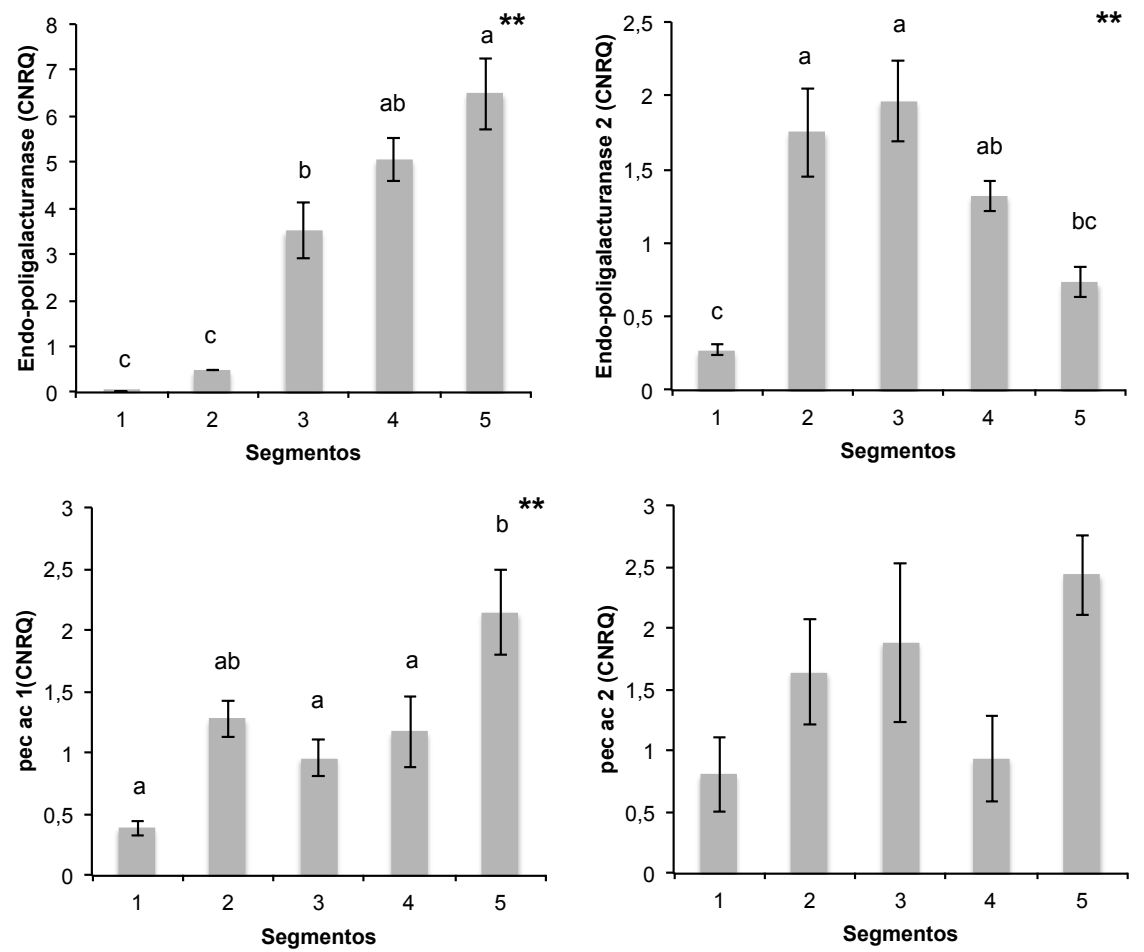

Figura 15. Perfil de expressão diferencial dos genes relacionados a enzimas de degradação de pectinas nos segmentos ( 1 a 5 ) de raízes de cana de açúcar. Dados representam média e o erro padrão $(n=5)$. Letras diferentes representam significância pelo teste ANOVA-Tuckey $(\mathrm{P}<0.05)$. ** não há homogeneidade.

Além da $\alpha$-arabinofuranosidase clivar substituições de arabinoses do arabinoxilanos, ela também pode estar relacionada com a hidrólise de ramificações neutras (arabinanos) do ramnogalacturanano 1 (RG-1). O padrão transcricional observado para o gene que codifica para a $\alpha$ arabinofuranosidase (SCQSRT1034D03.g) demonstrou um nível constante de expressão entre os segmentos 1 e 2 e um maior acúmulo de transcritos nos segmentos 3, 4 e 5 (Figura 16). Nas raízes de cana de açúcar, a $\beta$-galactosidase apresentou um padrão semelhante de expressão gênica em relação à $\alpha$-arabinofuranosidase, com menores níveis de transcritos no segmento 1 em relação aos demais, sendo que no segmento 2 e 5 a tendência foi de maior expressão (Figuras 17 e 16). Para a $\alpha$-galactosidase (SCQSRT2034G08.g) é demonstrado o mesmo padrão que o observado para $\beta$ galactosidase (Figura 17). A expressão e a atividade observadas para as $\beta$-galactosidase está relacionada a hidrolise das ramificações com galactanos presentes em RG-1. 


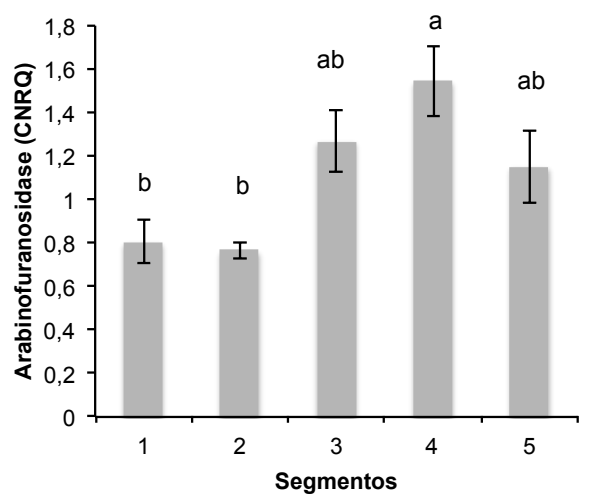

Figura 16. Perfil de expressão diferencial do gene de arabinofuranosidase nos segmentos (1 a 5) de raízes de cana de açúcar. Dados representam média e o erro padrão $(n=5)$. Letras diferentes representam significância pelo teste ANOVA-Tuckey $(\mathrm{P}<0.05)$.
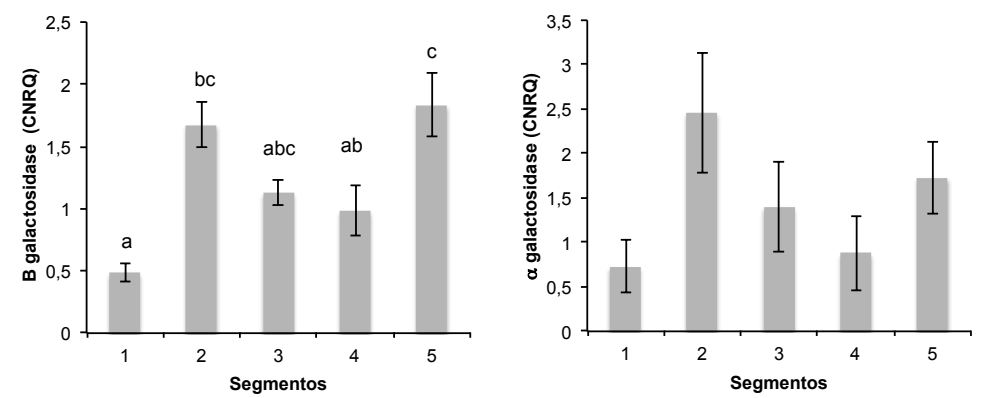

Figura 17. Perfil de expressão diferencial dos genes que codificam para $\alpha$ - e $\beta$-galactosidases nos segmentos (1 a 5) de raízes de cana de açúcar. Dados representam média e o erro padrão $(n=5)$. Letras diferentes representam significância pelo teste ANOVA-Tuckey $(p<0.05)$.

Foram quantificadas as expressões de dois genes que codificam para $\beta-1,3$ glucosidases (SCJLRT1023E06.g e SCCCRT2004C04.g), responsáveis pela hidrólise de $\beta$-glucanos ou calose, e o padrão de expressão observado para ambas foi o mesmo, sendo os níveis de transcritos menores no primeiro segmento, aumentando no segundo e mantendo-se constantes ao longo dos demais segmentos (Figura 18). 

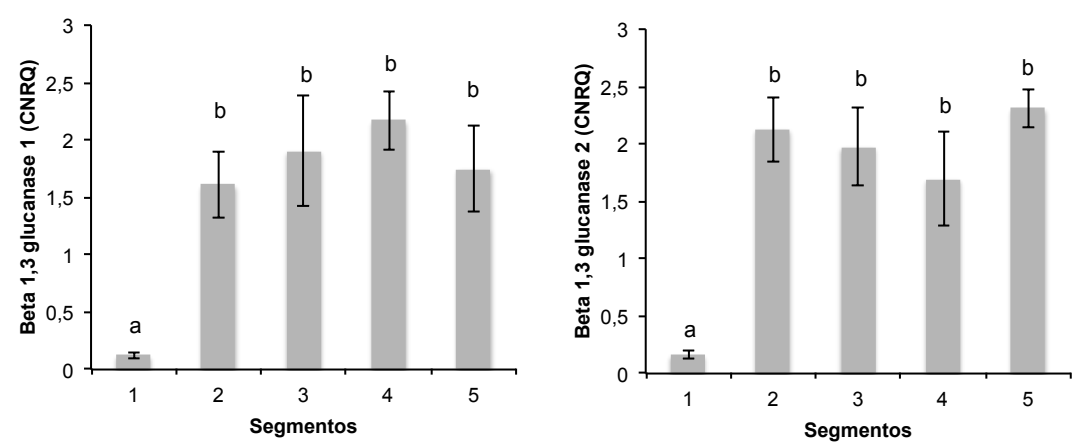

Figura 18. Perfil de expressão diferencial dos genes relacionados a enzimas de degradação de $\beta$-1,3-glucano (calose) nos segmentos (1 a 5) de raízes de cana de açúcar. Dados representam média e o erro padrão ( $n=5)$. Letras diferentes representam significância pelo teste ANOVA-Tuckey $(P<0.05)$. ** não há homogeneidade.

Foi observado também um aumento nos níveis de transcritos que correspondem a uma celulase (SCEQRT1024F11.g) e uma $\beta-1,4$ glucosidase (SCVPRT2073A02.g) no segmento 2 em relação aos demais segmentos (Figura 19). Estes dois genes estão relacionados à hidrolise de glucanos $\beta-1,4$ ligados, como a celulose.
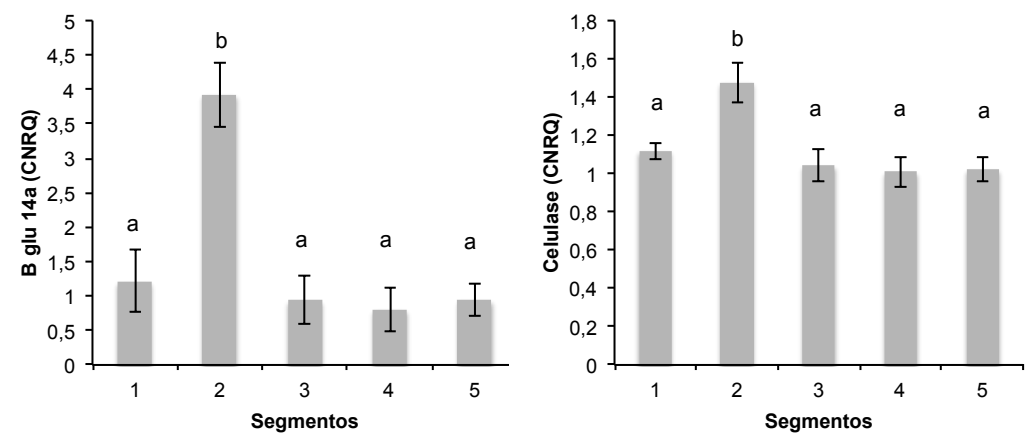

Figura 19. Perfil de expressão diferencial dos genes relacionados a degradação de celulose (celulase e $\beta$ - 1,4 glicosidase) nos segmentos ( 1 a 5) de raízes de cana de açúcar. Dados representam média e o erro padrão $(n=5)$. Letras diferentes representam significância pelo teste ANOVA-Tuckey $(P<0.05)$.

Três classes de enzimas em plantas são identificadas por degradar xilano: endo- $\beta$-xilanases, as $\beta$-xilosidases e as $\alpha$-arabinofuranosidases. As duas primeiras são responsáveis por clivar especificamente as ligações na cadeia de principal de xilano e a última remove as substituições de arabinoses de cadeia lateral do xilano ou de oligossacarídeos de arabinoxilanos, além de participar da hidrólise de pectinas, como descrito anteriormente (Figura 16). Nos segmentos de raízes de cana de açúcar, transcritos referentes a $\beta$-xilanase (SCJLRT1020A08.g) apresentaram maiores níveis de transcritos para todos os outros segmentos exceto para o primeiro segmento (Figura 20). Já o 
padrão transcricional observado para o gene que codifica para a $\alpha$-arabinofuranosidase (SCQSRT1034D03.g) demonstra maior acúmulo de transcritos nos segmentos 3, 4 e 5 (Figura 16). Observando esses dados transcricionais referentes a xilanases e arabinofuranosidases é possível sugerir que o arabinoxilano das raízes de cana de açúcar também esteja sendo modificado ao longo dos segmentos.

A $\alpha$-xilanase, apresenta o mesma padrão de transcritos da $\beta$-xilanase, porém está relacionada a modificações nas xiloses do xiloglucano (Figura 20). Na cana de açúcar é observado baixas concentrações desse polissacarídeo, entretanto durante a formação do aerênquima foi observado um aumento de xiloglucano no córtex das raízes ao longo dos segmentos (Leite, 2013) e esta enzima pode estar relacionada a essas modificações observadas no xiloglucano que interage fortemente com a celulose que também está sendo modificada.
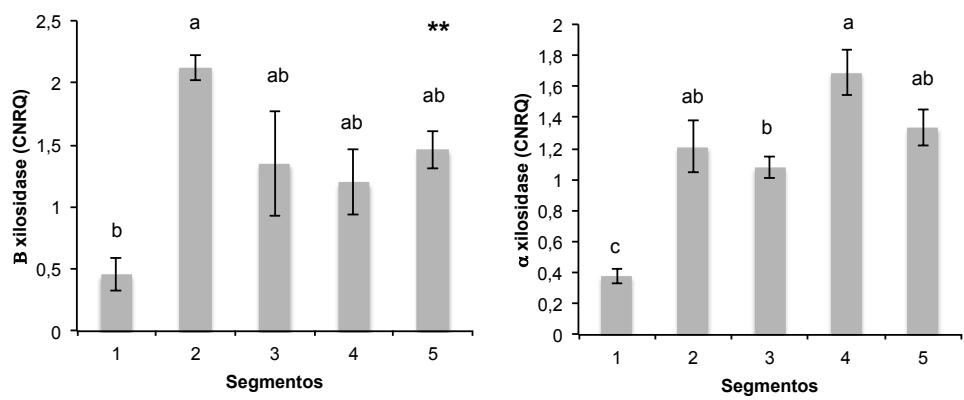

Figura 20. Perfil de expressão diferencial dos genes que codificam para $\alpha$ - e $\beta$-xilanases nos segmentos (1 a 5 ) de raízes de cana de açúcar. Dados representam média e o erro padrão $(n=5)$. Letras diferentes representam significância pelo teste ANOVA-Tuckey $(\mathrm{P}<0.05)$. ** não há homogeneidade.

\section{Quantificação das proteínas para a proteômica}

A fim de determinar a concentração de proteínas que foi utilizada na análise de proteômica, todas as extrações envolvendo os diferentes solventes foram quantificadas. Na Figura 21 é possível observar que, dentre as frações extraídas, as frações iniciais de $\mathrm{NaCl}$ são mais abundantes em proteínas do que os passos subsequentes: $\mathrm{CaCl}_{2}$, EDTA e LiCl. Entre os segmentos há uma diferença significativa do primeiro em relação aos demais no que diz respeito às proteínas totais extraídas com $\mathrm{NaCl}$. Isto é o esperado, pois esta região da raiz está o meristema apical, região 
de intensa atividade metabólica e síntese de proteínas, o que contribui para o maior número rendimento nesse segmento. Já na extração com EDTA, o segmento 3 apresenta maior rendimento e difere dos demais. Contudo, foi observado que a extração com EDTA e LiCl resulta em baixo rendimento em relação aos demais métodos (menos de 1 ug de proteína) e portanto esses extratos foram agrupados para serem analisadas conjuntamente. Sendo assim, após a junção das amostras de EDTA e LiCl, quantificou-se novamente o conteúdo de proteínas (Figura 22).

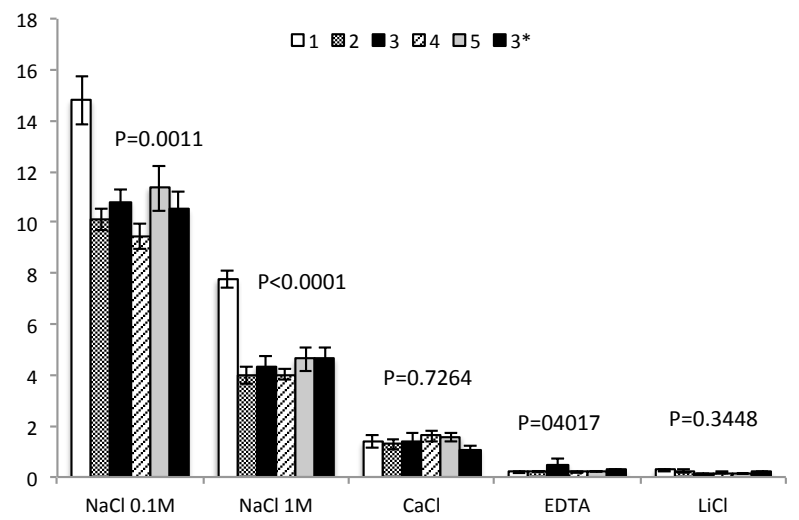

Figura 21. Conteúdo total de proteínas de todas frações extraídas sequencialmente dos segmentos das raízes de cana de açúcar. Valores de $P$ representam o teste ANOVA comparando os segmentos em cada extração $(n=5)$. O segmento $3^{*}$ representa uma segunda extração do mesmo segmento para compor a quantificação das proteínas pelo método de dimetilação, explicado em material e métodos.

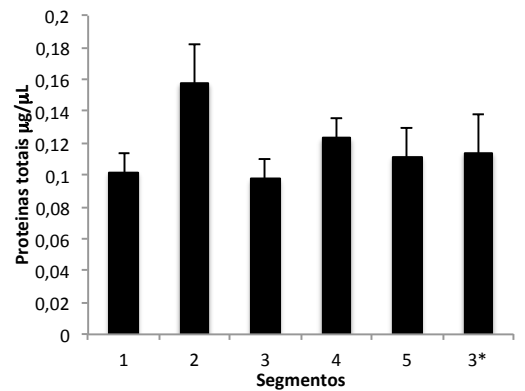

Figura 22. Conteúdo total de proteínas das frações extraídas sequencialmente dos segmentos das raízes de cana de açúcar. Frações de EDTA e LiCl foram unidas e quantificadas novamente, o segmento 3* representa uma segunda extração do mesmo segmento para compor a quantificação das proteínas pelo método de dimetilação, explicado em material e métodos.

\section{Análise das proteínas identificadas}

Após a análise de todas as extrações de proteínas e réplicas biológicas dos segmentos das raízes de cana de açúcar no software Maxquant, foram identificadas 1084 proteínas (Anexo 2). Destas, 113 foram relacionadas à síntese, degradação e modificação da parede celular de acordo 
com a ontologia genética obtida pelo banco de dados do Blast2GO (Anexo 2). Ao todo foram identificadas 34 glicosil hidrolases ( $3 \mathrm{GH} 18,7 \mathrm{GH} 3,5 \mathrm{GH} 1,2 \mathrm{GH} 28,1 \mathrm{GH} 31,11 \mathrm{GH} 17,5 \mathrm{GH} 38$ ) e outras enzimas e proteínas acessórias relacionadas às modificações da parede celular durante a formação do aerênquima como: 5 lacases, 7 expansinas, 1 pectinesterase, 2 poligalacturanases, 3 endo-1,3-1,4- $\beta$-glucanases, $2 \beta$-xilosidases, $3 \alpha$-galactosidases, 3 arabinofuranosidases, $2 \alpha$ glucosidases e 2 celulose-sintases (Anexo 2).

Devido a limitação de reprodutibilidade na técnica de proteômica de amostras complexas, foi realizado um filtro manual (conforme análise de dados Figura 6) das réplicas de amostragem que identificou apenas 525 proteínas que foram distribuídas em um heatmap com o valor das razões obtidas entre os segmentos (Anexo 3). Este conjunto de proteínas (que muitas vezes excluiu parte das enzimas relacionadas a parede celular) foi considerado tanto para a análise daquelas que podem estar envolvidas à morte celular programada quanto para as proteínas relacionadas à degradação e síntese de parede celular. A quantificação, obtida pelo método de marcação por dimetilação, foi realizada pela razão relativa entre os segmentos 1 para 2,2 para 3, 3 para 4 e 4 para 5, formando uma escala gradativa a favor do desenvolvimento da raiz, bem como da formação do aerênquima radicular.

Após essa análise explanatória foi necessário selecionar deste total de 525 proteínas aquelas de interesse tanto para analisar a PCD quanto modificações na parede celular durante a formação do aerênquima. Neste sentido, foram selecionadas 35 proteínas relacionadas à parede celular (Tabela 4 e Anexo 4) e 83 proteínas relacionadas à PCD (Anexo 5). Em relação as proteínas de parede celular foi realizado alguns cálculos de normalização com o intuito de apresentar da melhor forma os dados obtidos (Tabela 4), contudo os valores absolutos estão expressos no Anexo 4. Para as proteínas de $P C D$, o mesmo foi realizado porém os valores encontram-se na mesma tabela no Anexo 5.

Destas proteínas relacionadas a parede celular, algumas apresentam a mesma anotação embora sejam referentes à ESTs distintas (Tabela 4), estas foram re-anotadas com o auxilio do Blast2GO com a busca no Uniprot, NCBI e Kegg. As buscas dos termos ontogeneticos (Go-Terms) 
são apresentados na Tabela 4 e Anexos 4 e 5 com as respectivas proteínas e nome do SAS do Sucest.

Com o intuito de compreender melhor as diferenças entre as proporções (razões calculadas entre segmentos) das proteínas ao longo dos segmentos de raiz, foi realizada uma normalização nos dados de razão onde o segmento 1 foi considerado com o valor 0 e todos os outros foram relativizados em relação ao segmento anterior (Figura 23). Sendo assim foi possível observar que para algumas glicosil hidrolases o padrão de variação ao longo dos segmentos foi semelhante.

Foram identificadas 5 proteínas da família GH1 (possivelmente relacionadas com atividade de $\beta$-glucosidase) ainda que apenas 3 apresentassem valor significativo para o cálculo das razões entre os segmentos (Tabela 4). A proteína pertencente à família GH1 (ref. ao SAS SCEQHR1082B01.g) apresentou menor quantidade relativa entre a razão 1/2 representando que do segmento 1 para o 2 teve uma redução na concentração de proteínas. Em seguida há um aumento da proporção de GH1 em relação ao segmento 2 para os demais segmentos até o 5 verificado pelo aumento exponencial das razões entre 2/3, 3/4 e 4/5 (Tabela 4 e Figura 23). A GH1 (ref. ao SAS SCCCCL3001B10.b) também reduziu a proporção de proteínas do segmento 2 em relação ao 1 e reduziu a concentração de proteínas ao longo dos segmentos. A outra GH1 (ref. ao SAS SCAGLR1021F11.g) mostrou um aumento do segmento 1 para o 2 sendo constante entre 2, 3 e 5 e reduzindo a proporção no segmento 5 (Figura 23).

No que diz respeito as glicosil hidrolases da família GH17, na qual estão situadas as proteínas identificadas como $\beta-1,3$ glucanases e que podem hidrolisar o $\beta$-glucano, foram encontradas 6 proteínas, sendo que 3 delas apresentaram diferenças significativas. Duas GH17 (ref. aos SAS SCEZHR1088G11.g e SCEQRT1025C10.g) apresentaram menor abundância do segmento 1 para os demais ao longo de todas as razões entre os segmentos, enquanto que outra enzima da família (ref. ao SAS SCJFRT1008G05.g) tornou-se mais abundante a partir do segmento 3 em relação para os demais (Tabela 4 e Figura 23). Duas GH17 que foram encontradas nos segmentos e não tiveram diferenças significativas apresentaram uma tendência de maior acúmulo ao longo dos segmentos enquanto que outra foi de diminuição ao longo dos segmentos (Tabela 4). Contudo ao 
realizar o alinhamento de sequencias foi observado que há grande similaridade entre essas GH17, podendo estas fazerem parte da mesma proteína.

Apesar de apresentar apenas duas endo-1,3(4) $\beta$-glucanases, que são conhecidas como liquenases e degradam exclusivamente $\beta$-glucanano, apenas uma dessas proteínas apresentou diferenças significativas (ref. ao SAS SCVPRT2081E09.g) com maior abundância no segmento 2 em relação ao segmento 1 , aumentando também gradativamente a razão até o 4 , em seguida de diminuindo sua razão no 4/5 que corresponde a diminuição da abundância da proteína no quinto segmento, que segue o mesmo padrão de algumas GH17 (Figura 23), a outra liquenase (SCCCLR2C01H02.g) apesar de não ser significativa $(P=0,083)$ mostra um padrão diferenciado de proporção relativa entre segmentos, permanece constante a expressão do segmento 1 ao 3 , diminui no quatro e volta a ser igual aos demais no quinto segmento (Figura 23).

As xilosidases e arabinofuranosidases que são agrupadas na família GH3 apresentam um perfil muito similar, todas tornando-se mais abundantes na transição do primeiro para o segundo segmento. Apenas metade dessas enzimas da família GH3 prosseguiram em seu padrão crescente entre as razões dos segmentos 2/3 (ref. aos SAS SCAGRT2037A11.g; SCCCRT1002G03.g e SCEQLR1093F09.g) reduzindo as razões entre os segmentos subsequentes. As demais GH3 reduziram a quantidade a partir da razão 3/4 (Tabela 4 e Figura 23). Entre as enzimas cuja identificação sugere se tratem de $\alpha$-arabinofuranosidases ou $\beta$-xilosidase (ref. aos SAS SCCCCL4009F05.g e SCQSRT1034D03.g), foi observado um aumento no segmento 2 em relação ao 1, seguido de uma redução em todos os segmentos (Tabela 4 e Figura 23).

A GH18 (probable chitinase or xylanase inibitor - SCMCCL6051E03.g) apresentou um padrão bimodal de quantidade relativa entre os segmentos com maiores níveis em $1 / 2$ e $3 / 4$ e menores em $2 / 3$ e 4/5. Ou seja, sua ocorrência aumenta nos segmentos 2 e 4 e reduz em 3 e 5 (Tabela 4 e Figura 23). Duas $\beta$-galactosidases (ref. aos SAS SCCCCL6004H07.g e SCEPRT2044F09.g) apresentam esse mesmo padrão bimodal apresentado pela GH18, com níveis aumentados em 1/2 e 3/4. Contudo, uma terceira $\beta$-galactosidase (SCCCCL4001H11.g) apresentou padrão distinto das razões, sendo crescente ao longo dos segmentos e reduzindo no quinto (4/5) (Tabela 4 e Figura 23). 
As proteínas relacionadas a expansão celular (expansinas) também apresentaram esse mesmo padrão, porém não apontaram diferenças significativas (Tabela 4). Duas expansinas foram identificadas e mostram padrões distintos entre si, uma delas (ref. ao SAS SCCCCL4006H09.g) foi maior apenas no segmento 1 decaindo drasticamente nos demais, enquanto a outra expansina (ref. ao SAS SCSGLV1004F11.g) apresentou um redução na quantidade relativa apenas a partir do segmento 3, aumentando novamente no segmento 5 (Tabela 4), esta ultima apresenta o mesmo padrão dos transcritos de expansina que aumentam no segmento 1 e 5 (Figura 14).

As proteínas fasciclin-like arabinogalactan (proteoglicanos que muitas vezes são glicosiladas com estruturas de arabinogalactanos do tipo II) apresentaram maiores níveis no segmento 2 em relação ao 1 reduzindo entre os outros segmentos (Tabela 4).

A família de enzimas que teve mais proteínas encontradas e significativas foi a GH3 (relacionadas às xilosidases e arabinofuranosidases), onde a maioria apresentou o mesmo padrão ao longo dos segmentos (Figura 23). Já para a família GH1 que contempla as beta-glicosidases, apresenta maiores proporções ao longo dos segmentos enquanto que outra apresenta menor proporção no segmento 2. O que é possível concluir observando todos os dados é que há um aumento relativo nos níveis de glicosil hidrolases de parede celular a partir do segmento 2, o que persiste entre os segmentos 3 e 4 . De acordo com suas atividades enzimáticas e seus padrões de ocorrência, estas podem estar atuando na modificação da parede ao longo da formação do aerênquima (Tabela 4 e Figura 23). 
Tabela 4. Valores normalizados das razões entre as proteínas de parede celular encontradas nos diferentes segmentos das raizes de cana de açúcar. Valores representam a mediana entre 5 réplicas amostrais e valores de $P$ significativos são apresentados em negrito $(P>0,05)$ obtidos pelo software de montagem e quantificaçao Maxquant e de estatistica Perseus. Termos GO foram obtidos com as ferramentas do software Blast2GO. Valores negativos representam diminuiu a concentraçao alo longo do segmento de a para o $\mathrm{b}(\mathrm{a} / \mathrm{b})$ valores positivos representam que aumentou a concetração ao longo dos segmentos de a para $\mathrm{b}$.

\begin{tabular}{|c|c|c|c|c|c|c|c|c|c|c|}
\hline SAS - Sucest & Nome da proteína, espécie (banco de dados) & $\operatorname{seg} 1 / 2$ & $\begin{array}{l}\text { erença entr } \\
\text { seg } 2 / 3\end{array}$ & $\begin{array}{l}\text { os segmen } \\
\text { seg } 3 / 4\end{array}$ & $\operatorname{seg} 4 / 5$ & $\begin{array}{l}\text { ANOVA P- } \\
\text { value }\end{array}$ & GO processo biológico & GO componente celular & GO função molecular & informações do kegg \\
\hline 1 SCQSRT2034G08.g & Alpha-galactosidase(UNIPROT) & 0.243 & 0.329 & 0.272 & -0.432 & 0.353 & $\begin{array}{l}\text { fintra-Golgi vesicle-mediated transport; root hair elongation; starch } \\
\text { biosynthetic process }\end{array}$ & $\begin{array}{l}\text { apoplast; plant-type cell } \\
\text { wall; vacuole }\end{array}$ & alpha-galactosidase activity & $\begin{array}{l}\text { alpha-galactosidase } \\
\text { [EC:3.2.1.22];E3.2.1.22B }\end{array}$ \\
\hline 2 SCQSRT1034D03.g & Alpha-L-arabinofuranosidase(UNIPROT) & 0.708 & 0.439 & 0.198 & -0.101 & 0.000 & $\begin{array}{l}\text { glucuronoxylan metabolic process; L-arabinose metabolic process; xylan } \\
\text { biosynthetic process; xylan catabolic process }\end{array}$ & $\begin{array}{l}\text { apoplast;plant-type cell } \\
\text { wall;;vacuole }\end{array}$ & $\begin{array}{l}\text { alpha-N-arabinofuranosidase } \\
\text { activity;xylan 1,4-beta- } \\
\text { xylosidase activity }\end{array}$ & $\begin{array}{l}\text { alpha- } \mathrm{N}- \\
\text { arabinofuranosidase } \\
\text { [EC:3.2.1.55];E3.2.1.55 }\end{array}$ \\
\hline 3 SCEQRT1025C10.g & $\begin{array}{l}\text { beta-1,3-glucanase Glycosyl hydrolases family } \\
17 \text { (UNIPROT) }\end{array}$ & 0.782 & 0.282 & 0.052 & 0.083 & 0.000 & $\begin{array}{l}\text { anatomical structure form. involved in morphogenesis;carbohydrate } \\
\text { metabolic processorgan development;organelle organization;post- } \\
\text { embryonic development; }\end{array}$ & $\begin{array}{l}\text { anchored to plasma } \\
\text { membrane;plant-type cell wall }\end{array}$ & $\begin{array}{l}\text { hydrolase activity, hydrolyzing } \\
\text { 0-glycosyl compounds }\end{array}$ & \\
\hline 4 SCEZHR1088G11.g & $\begin{array}{l}\text { beta-1,3-glucanase Glycosyl hydrolases family } \\
17 \text { (UNIPROT) }\end{array}$ & 0.532 & -0.111 & -0.107 & -0.157 & 0.004 & $\begin{array}{l}\text { asymmetric cell division; auxin polar transport; carbohydrate metabolic } \\
\text { process; cellular response to organic substance; cellular response to } \\
\text { oxygen-containing compound; regulation of cell size; regulation of } \\
\text { meristem growth; root morphogenesis }\end{array}$ & $\begin{array}{l}\text { anchored to plasma } \\
\text { membrane;endoplasmic } \\
\text { reticulum;nucleus;plant-type cell } \\
\text { wall;plasmodesma }\end{array}$ & $\begin{array}{l}\text { glucan endo-1,3-beta-D- } \\
\text { glucosidase activity }\end{array}$ & \\
\hline 5 SCJFRT1008G05.g & $\begin{array}{l}\text { beta-1,3-glucanase Glycosyl hydrolases family } \\
\text { 17(UNIPROT) }\end{array}$ & 0.034 & 0.498 & 0.288 & 0.100 & 0.020 & $\begin{array}{l}\text { carbohydrate metabolic process; regulation of innate immune response; } \\
\text { regulation of programmed cell death;response to bacterium; response to } \\
\text { cold }\end{array}$ & $\begin{array}{l}\text { anchored to plasma } \\
\text { membrane;apoplast;plant-type } \\
\text { cell wall;;plasmodesma;vacuole }\end{array}$ & $\begin{array}{l}\text { beta-glucosidase } \\
\text { activity;cellulase } \\
\text { activity;protein binding }\end{array}$ & \\
\hline 6 SCRFAM2071E02.g & $\begin{array}{l}\text { beta-1,3-glucanase Glycosyl hydrolases family } \\
17 \text { (UNIPROT) }\end{array}$ & 0.144 & 0.167 & 0.043 & 0.234 & 0.241 & $\begin{array}{l}\text { carbohydrate metabolic process; cell communication; regulation of cellular } \\
\text { process; regulation of gene expression, epigenetic; response to organic } \\
\text { substance; response to oxygen-containing compound }\end{array}$ & $\begin{array}{l}\text { anchored to plasma } \\
\text { membrane;cell wall;cytoplasmic } \\
\text { part;nucleus;plasmodesma }\end{array}$ & $\begin{array}{l}\text { hydrolase activity, hydrolyzing } \\
\text { O-glycosyl compounds }\end{array}$ & \\
\hline 7 SCRFLR1055B07.g & $\begin{array}{c}\text { beta-1,3-glucanase Glycosyl hydrolases family } \\
17 \text { (UNIPROT) }\end{array}$ & -0.431 & 0.022 & -0.160 & -0.157 & 0.278 & cytokinin mediated signaling pathway & plasma membrane & & \\
\hline 8 SCRURT2006B10.g & $\begin{array}{l}\text { beta-1,3-glucanase Glycosyl hydrolases family } \\
17 \text { (UNIPROT) }\end{array}$ & 0.037 & 0.079 & 0.174 & 0.195 & 0.605 & $\begin{array}{l}\text { carbohydrate metabolic process; gene silencing; multicellular organismal } \\
\text { development; organelle organization }\end{array}$ & $\begin{array}{l}\text { anchored to membrane;cell } \\
\text { wall;plasma } \\
\text { membrane;plasmodesma }\end{array}$ & $\begin{array}{l}\text { hydrolase activity, hydrolyzing } \\
\text { O-glycosyl compounds }\end{array}$ & \\
\hline 9 ScCCCL4001H11.g & Beta-galactosidase(UNIPROT) & 0.707 & 0.258 & 0.230 & -0.047 & 0.000 & $\begin{array}{l}\text { alcohol biosynthetic process; carbohydrate metabolic process;catabolic } \\
\text { process; cell wall biogenesis; developmental cell growth; developmental } \\
\text { growth involved in morphogenesis; hydrogen peroxide metabolic process; } \\
\text { plant-type cell wall modification; regulation of biological process }\end{array}$ & $\begin{array}{l}\text { apoplast; cytosol;plant-type cell } \\
\text { wall;plasmodesma;vacuolar } \\
\text { membrane }\end{array}$ & $\begin{array}{l}\text { beta-galactosidase } \\
\text { activity; carbohydrate binding }\end{array}$ & \\
\hline 10 ScCCCL6004H07.g & Beta-galactosidase(UNIPROT) & 0.179 & -0.674 & 0.678 & 0.018 & 0.000 & $\begin{array}{l}\text { biological regulation; carbohydrate metabolic process; cellular } \\
\text { biosynthetic process; ;cellular process involved in reproduction; plant-type } \\
\text { cell wall organization }\end{array}$ & $\begin{array}{l}\text { apoplast;plant-type cell } \\
\text { wall;plasmodesma;vacuolar } \\
\text { membrane }\end{array}$ & beta-galactosidase activity & \\
\hline 11 SCEPRT2044F09.g & Beta-galactosidase(UNIPROT) & 0.101 & -0.457 & 0.650 & -0.160 & 0.000 & $\begin{array}{l}\text { carbohydrate metabolic process; cellular cation homeostasis; cellular } \\
\text { modified amino acid biosynthetic process; divalent metal ion transport; } \\
\text { hydrogen peroxide catabolic process; plant-type cell wall biogenesis; plant- } \\
\text { type cell wall modification; polyamine catabolic process; regulation of } \\
\text { meristem growth; response to karrikin; root hair elongation }\end{array}$ & $\begin{array}{l}\text { apoplast; cytosol;plant-type cell } \\
\text { wall;plasmodesma;vacuolar } \\
\text { membrane }\end{array}$ & beta-galactosidase activity & \\
\hline 12 ScCCCL4009F05.g & $\begin{array}{l}\text { Beta-xylosidase/alpha-L-arabinofuranosidase (GH } \\
\text { family 3)(UNIPROT) }\end{array}$ & 0.536 & -0.011 & -0.043 & -0.044 & 0.000 & $\begin{array}{l}\text { arabinan catabolic process; response to arsenic-containing substance;seed } \\
\text { coat development; xylan catabolic process }\end{array}$ & $\begin{array}{l}\text { apoplast; chloroplast;plant-type } \\
\text { cell wall; ;lasmodesma;vacuolar } \\
\text { membrane }\end{array}$ & $\begin{array}{l}\text { alpha-N-arabinofuranosidase } \\
\text { activity;yylan 1,4-beta- } \\
\text { xylosidase activity }\end{array}$ & $\begin{array}{l}\text { beta-D-xylosidase } 4 \\
{[\text { [EC:3.2.1.37]; } Y Y L 4}\end{array}$ \\
\hline 13 SCQSAM1030G04.g & $\begin{array}{l}\text { Beta-xylosidase/alpha-L-arabinofuranosidase (GH } \\
\text { family 3)(UNIPROT) }\end{array}$ & -0.420 & -0.108 & -0.039 & -0.095 & 0.279 & $\begin{array}{l}\text { arabinan catabolic process; response to arsenic-containing substance; } \\
\text { seed coat development; xylan catabolic process }\end{array}$ & $\begin{array}{l}\text { apoplast; chloroplast;plant-type } \\
\text { cell wall;plasmodesma; vacuolar } \\
\text { membrane }\end{array}$ & $\begin{array}{l}\text { alpha-N-arabinofuranosidase } \\
\text { activity;yylan 1,4-beta- } \\
\text { xylosidase activity }\end{array}$ & \\
\hline
\end{tabular}




\section{Continuação Tabela 4.}

\begin{tabular}{|c|c|c|c|c|c|c|c|c|c|c|}
\hline SAS- Sucest & Nome da proteína, espécie (banco de dados) & $\operatorname{seg} 1 / 2^{D i}$ & $\begin{array}{l}\text { erença entit } \\
\text { seg } 2 / 3\end{array}$ & $\begin{array}{l}\text { os segmen } \\
\text { seg } 3 / 4\end{array}$ & seg $4 / 5$ & $\begin{array}{l}\text { ANOVA P- } \\
\text { value }\end{array}$ & GO processo biológico & GO componente celular & GO função molecular & informações do kegg \\
\hline 14 SCCCLR2C01H02.g & $\begin{array}{c}\text { Endo-1,3;1,4-beta-D-glucanase OS=Zea mays } \\
\text { PE=1 SV=1 (UNIPROT) }\end{array}$ & -0.208 & -0.001 & -0.328 & 0.304 & 0.083 & $\begin{array}{l}\text { glycolysis;Golgi organization;hyperosmotic response;response to cadmium } \\
\text { ion;response to salt stress;response to temperature stimulus; water } \\
\text { transport }\end{array}$ & $\begin{array}{l}\text { apoplast;;ytosol;nucleus;plasma } \\
\text { membrane }\end{array}$ & hydrolase activity & $\begin{array}{c}\text { carboxymethylenebutenol } \\
\text { dase } \\
\text { [EC:3.1.1.45];;3.1.1.4.45 }\end{array}$ \\
\hline 15 SCVPRT2081E09.g & $\begin{array}{l}\text { Endo-1,3(4)-beta-glucanase 1;Endo-1,4-beta- } \\
\text { glucanase 1; Endo-1,3-beta-glucanase } \\
\text { 1;Laminarinase-1; (UNIPROT) }\end{array}$ & 0.409 & 0.243 & 0.186 & -0.118 & 0.052 & $\begin{array}{l}\text { amino acid import; cell wall macromolecule catabolic process;endoplasmic } \\
\text { reticulum unfolded protein response;:ER to Golgi vesicle-mediated } \\
\text { transport;:N-terminal protein myristoylation }\end{array}$ & & $\begin{array}{l}\text { glucan endo-1,3-beta- } \\
\text { glucanase activity, C-3 } \\
\text { substituted reducing } \\
\text { group; } \text { glucan endo-1,4-beta- } \\
\text { glucanase activity, } \mathrm{C}-3 \\
\text { substituted reducing group }\end{array}$ & \\
\hline 16 ScCCCL4006H09.g & Expansin(UNIPROT) & -0.387 & 0.077 & -0.251 & -0.163 & 0.746 & $\begin{array}{l}\text { cell growth; developmental growth involved in morphogenesis; plant-type } \\
\text { cell wall modification; sexual reproduction; trichoblast differentiation }\end{array}$ & $\begin{array}{l}\text { extracellular region; Golgi } \\
\text { apparatus; plant-type cell wall; } \\
\text { plasmodesma }\end{array}$ & & \\
\hline 17 SCSGLV1004F11.g & Expansin(UNIPROT) & 0.057 & -0.243 & 0.019 & 0.203 & 0.195 & $\begin{array}{l}\text { organelle organization; plant-type cell wall loosening; plant-type cell wall } \\
\text { modification involved in multidimensional cell growth; regulation of } \\
\text { stomatal movement; response to gibberellin stimulus; response to red } \\
\text { light; syncytium formation; unidimensional cell growth }\end{array}$ & $\begin{array}{l}\text { chloroplast; cytosol;extracellular } \\
\text { region;plant-type cell } \\
\text { wall;plasmodesma }\end{array}$ & $\begin{array}{l}\text { structural constituent of cell } \\
\text { wall }\end{array}$ & \\
\hline 18 SCEPLR1051B04.g & Fasciclin-like arabinogalactan protein(UNIPROT) & 0.172 & -0.034 & 0.155 & -0.046 & 0.265 & $\begin{array}{l}\text { alcohol biosynthetic process; cell growth; cellular component organization; } \\
\text { plant-type cell wall organization or biogenesis; regulation of hormone } \\
\text { levels;shoot system development; single-organism transport; steroid } \\
\text { biosynthetic process; trichoblast differentiation }\end{array}$ & $\begin{array}{l}\text { anchored to plasma } \\
\text { membrane;cell wall;vacuolar } \\
\text { membrane }\end{array}$ & & \\
\hline 19 SCQGRT1040D08.g & Fasciclin-like arabinogalactan protein(UNIPROT) & -1.209 & -0.195 & -1.255 & 0.267 & 0.471 & $\begin{array}{l}\text { alcohol biosynthetic process;biological regulation;secondary cell wall } \\
\text { biogenesis;steroid biosynthetic process; trichoblast differentiation }\end{array}$ & $\begin{array}{l}\text { anchored to plasma membrane; } \\
\text { Golgi apparatus; plant-type cell } \\
\text { wall; plasmodesma }\end{array}$ & & \\
\hline 20 SCQSLR1040G04.g & Fasciclin-like arabinogalactan protein(UNIPROT) & 0.510 & -0.365 & -0.159 & -0.138 & 0.007 & $\begin{array}{l}\text { acetyl-CoA metabolic process; brassinosteroid biosynthetic process; cell } \\
\text { growth; plant-type cell wall organization; regulation of meristem growth; } \\
\text { root development; secondary cell wall biogenesis; sterol biosynthetic } \\
\text { process }\end{array}$ & $\begin{array}{l}\text { anchored to plasma membrane; } \\
\text { cell wall; cytoplasmic part; } \\
\text { intracellular membrane-bounded } \\
\text { organelle }\end{array}$ & & \\
\hline 21 SCRFLR1034D04.g & Fasciclin-like arabinogalactan protein(UNIPROT) & 0.514 & -0.074 & -0.472 & -0.133 & 0.002 & $\begin{array}{l}\text { brassinosteroid biosynthetic process;cell growth;secondary cell wall } \\
\text { biogenesis;,trichoblast differentiation }\end{array}$ & $\begin{array}{l}\text { anchored to plasma } \\
\text { membrane; Golgi apparatus;plant- } \\
\text { type cell wall;plasmodesma }\end{array}$ & & \\
\hline 22 SCVPRZ2036F10.g & Fasciclin-like arabinogalactan protein(UNIPROT) & 0.402 & 0.045 & -0.158 & 0.027 & 0.198 & $\begin{array}{l}\text { acetyl-CoA metabolic process; brassinosteroid biosynthetic process;cell } \\
\text { growth; plant-type cell wall organization; regulation of meristem growth; } \\
\text { root development; secondary cell wall biogenesis; sterol biosynthetic } \\
\text { process }\end{array}$ & $\begin{array}{l}\text { anchored to plasma } \\
\text { membrane;cell wall;cytoplasmic } \\
\text { part;intracellular membrane- } \\
\text { bounded organelle }\end{array}$ & & \\
\hline 26 SCAGLR1021F11.g & Glycosyl hydrolase family 1(UNIPROT) & -0.584 & -0.474 & -0.282 & -0.177 & 0.000 & $\begin{array}{l}\text { carbohydrate metabolics ;cellular response to cold; defense response by } \\
\text { callose deposition in cell wall; defense response to fungus; induced } \\
\text { systemic resistance; negative regulation of defense response; response to } \\
\text { salt stress; response to symbiotic fungus }\end{array}$ & $\begin{array}{l}\text { apoplast ; chloroplast envelope; } \\
\text { cytosolic ribosome; endoplasmic } \\
\text { reticulum; ER body; Golgi } \\
\text { apparatus; membrane ;nucleus; } \\
\text { peroxisome; ;lant-type cell wall; } \\
\text { plasmodesma; vacuole }\end{array}$ & $\begin{array}{l}\text { beta-mannosidase } \\
\text { activity;cellobiose glucosidase } \\
\text { activity; copper ion } \\
\text { binding;fucosidase } \\
\text { activity;phosphatidic acid } \\
\text { binding;protease binding }\end{array}$ & $\begin{array}{c}\text { beta-glucosidase } \\
{[\text { [EC:3.2.1.21];E3.2.1.21 }}\end{array}$ \\
\hline 23 scCCCL3001B10.b & Glycosyl hydrolase family 1 (UNIPROT) & 0.492 & 0.077 & 0.032 & -0.276 & 0.000 & $\begin{array}{l}\text { carbohydrate metabolic process; cellular response to ethylene stimulus; } \\
\text { cellular response to iron ion;cellular response to nitric oxide; lignin } \\
\text { biosynthetic process; pollen tube growth; regulation of cellular process; } \\
\text { response to carbohydrate stimulus; response to other organism; response } \\
\text { to salt stress }\end{array}$ & $\begin{array}{l}\text { apoplast;chloroplast;cytosolic } \\
\text { ribosome;Golgi apparatus;plant- } \\
\text { type cell wall;plasmodesma }\end{array}$ & $\begin{array}{l}\text { beta-mannosidase } \\
\text { activity;cellobiose glucosidase } \\
\text { activity;coniferin beta- } \\
\text { glucosidase activity }\end{array}$ & $\begin{array}{l}\text { beta-glucosidase } \\
\text { [EC:3.2.1.21];bg|B }\end{array}$ \\
\hline 24 SCEQHR1082B01.g & Glycosyl hydrolase family 1(UNIPROT) & -0.681 & 0.463 & 0.341 & 0.167 & 0.000 & $\begin{array}{l}\text { carbohydrate metabolic process; ; lucosinolate metabolic process; pollen } \\
\text { tube growth; response to other organism; response to salt stress }\end{array}$ & $\begin{array}{l}\text { apoplast ; chloroplast; cytosolic } \\
\text { ribosome; Golgi apparatus; } \\
\text { membrane; plant-type cell wall; } \\
\text { plasmodesma }\end{array}$ & $\begin{array}{l}\text { beta-mannosidase } \\
\text { activity;cellobiose glucosidase } \\
\text { activity;esculin beta- } \\
\text { glucosidase } \\
\text { activity;thioglucosidase } \\
\text { activity }\end{array}$ & $\begin{array}{c}\text { beta-glucosidase } \\
\text { [EC:3.2.1.21];E3.2.1.21 }\end{array}$ \\
\hline 25 SCEQLB1066E08.g & Glycosyl hydrolase family 1 (UNIPROT) & 0.337 & -0.035 & -0.125 & 0.131 & 0.192 & $\begin{array}{l}\text { carbohydrate metabolic process; cellular component organization; cellular } \\
\text { response to ethylene stimuluss; iignin biosynthetic process; response to } \\
\text { carbohydrate stimulus }\end{array}$ & $\begin{array}{l}\text { apoplast;chloroplast;;ytosolic } \\
\text { ribosome;Golgi apparatus;plant- } \\
\text { type cell wall;plasmodesma }\end{array}$ & $\begin{array}{l}\text { beta-mannosidase } \\
\text { activity;cellobiose glucosidase } \\
\text { activity }\end{array}$ & $\begin{array}{l}\text { beta-glucosidase } \\
\text { [EC:3.2.1.21];bglB }\end{array}$ \\
\hline 26 SCJFLR1017E03.g & Glycosyl hydrolase family 1 (UNIPROT) & 0.300 & -0.093 & -0.129 & -0.083 & 0.168 & $\begin{array}{l}\text { carbohydrate metabolic process; cellular response to ethylene stimulus; } \\
\text { lignin biosynthetic process }\end{array}$ & $\begin{array}{l}\text { apoplast; chloroplast; cytosolic } \\
\text { ribosome; Golgi ipparatus; } \\
\text { membrane; plant-type cell wall; } \\
\text { plasmodesma }\end{array}$ & $\begin{array}{l}\text { beta-mannosidase } \\
\text { activity;cellobiose glucosidase } \\
\text { activity;coniferin beta- } \\
\text { glucosidase activity;esculin } \\
\text { beta-glucosidase activity }\end{array}$ & \\
\hline
\end{tabular}


Continuação Tabela 4.

\begin{tabular}{|c|c|c|c|c|c|c|c|c|c|c|c|}
\hline \multicolumn{2}{|r|}{ SAS - Sucest } & Nome da proteína, espécie (banco de dados) & \multicolumn{4}{|c|}{ Diferença entre os segmentos } & $\begin{array}{l}\text { ANOVA P- } \\
\text { value }\end{array}$ & GO processo biológico & GO componente celular & GO função molecular & informaçōes do kegg \\
\hline 27 & SCAGRT2037A11.g & $\begin{array}{l}\text { Glycosyl hydrolase family } 3 \text { protein } \\
\text { (Xylosidase)(UNIPROT) }\end{array}$ & 0.705 & seg $2 / 3$ & $\operatorname{seg} 3 / 4$ & $\operatorname{seg} 4 / 5$ & value & $\begin{array}{l}\text { arabinan catabolic process; regulation of meristem growth; response to } \\
\text { arsenic-containing substance; seed coat development; } x \text { ylan catabolic } \\
\text { process }\end{array}$ & $\begin{array}{l}\text { apoplast; chloroplast;plant-type } \\
\text { cell wall;plasmodesma;vacuolar } \\
\text { membrane }\end{array}$ & $\begin{array}{l}\text { alpha-N-arabinofuranosidase } \\
\text { activity;xylan 1,4-beta- } \\
\text { xylosidase activity }\end{array}$ & \\
\hline 28 & SCCCRT1002G03.g & $\begin{array}{l}\text { Glycosyl hydrolase family } 3 \text { protein } \\
\text { (Xylosidase)(UNIPROT) }\end{array}$ & 0.475 & 0.252 & -0.179 & -0.136 & 0.009 & $\begin{array}{l}\text { arabinan catabolic process; response to chemical stimulus; seed coat } \\
\text { development; xylan catabolic process }\end{array}$ & $\begin{array}{l}\text { apoplast;chloroplast;plant-type } \\
\text { cell wall;plasmodesma;vacuolar } \\
\text { membrane }\end{array}$ & $\begin{array}{l}\text { alpha-N-arabinofuranosidase } \\
\text { activity;xylan 1,4-beta- } \\
\text { xylosidase activity }\end{array}$ & $\begin{array}{l}\text { beta-D-xylosidase } 4 \\
{[\text { [EC:3.2.1.137];XYL4 }}\end{array}$ \\
\hline 29 & SCCCSB1003H06.g & $\begin{array}{l}\text { Glycosyl hydrolase family } 3 \text { protein } \\
\text { (Xylosidase)(UNIPROT) }\end{array}$ & 0.605 & -0.276 & 0.005 & -0.138 & 0.001 & $\begin{array}{l}\text { arabinan catabolic process; regulation of meristem growth; response to } \\
\text { arsenic-containing substance; seed coat development; xylan catabolic } \\
\text { process }\end{array}$ & $\begin{array}{l}\text { apoplast;chloroplast;plant-type } \\
\text { cell wall;plasmodesma;vacuolar } \\
\text { membrane }\end{array}$ & $\begin{array}{l}\text { alpha-N-arabinofuranosidase } \\
\text { activity;xylan 1,4-beta- } \\
\text { xylosidase activity }\end{array}$ & \\
\hline 30 & SCEZRZ3015A12.g & $\begin{array}{l}\text { Glycosyl hydrolase family } 3 \text { protein } \\
\text { (Xylosidase)(UNIPROT) }\end{array}$ & 0.590 & -0.249 & 0.055 & -0.091 & 0.001 & carbohydrate metabolic process & & $\begin{array}{l}\text { hydrolase activity, hydrolyzing } \\
\text { 0-glycosyl compounds }\end{array}$ & $\begin{array}{l}\text { beta-D-xylosidase } 4 \\
{[\text { [EC:3.2.1.1.37];XYL4 }}\end{array}$ \\
\hline 31 & SCEQLR1093F09.g & glycosyl hydrolase family 3 protein(UNIPROT) & 0.220 & 0.123 & -0.013 & -0.432 & 0.001 & carbohydrate metabolic process & & $\begin{array}{l}\text { hydrolase activity, hydrolyzing } \\
\text { O-glycosyl compounds }\end{array}$ & $\begin{array}{l}\text { beta-glucosidase } \\
\text { [EC:3.2.1.21]; bglX }\end{array}$ \\
\hline 32 & SCEZLB1007A09.g & glycosyl hydrolase family 3 protein(UNIPROT) & 0.272 & -0.014 & 0.235 & 0.108 & 0.500 & $\begin{array}{l}\text { carbohydrate metabolic process;cell wall organization or } \\
\text { biogenesis;cellular }\end{array}$ & $\begin{array}{l}\text { anchored to membrane; cytosol; } \\
\text { extracellualar region; plant-type cell } \\
\text { wall; plasma membrane; } \\
\text { plasmodesma; vacuole }\end{array}$ & $\begin{array}{l}\text { xylan 1,4-beta-xylosidase } \\
\text { activity }\end{array}$ & $\begin{array}{l}\text { beta-glucosidase } \\
\text { [EC:3.2.1.21];bg|X }\end{array}$ \\
\hline 33 & SCCCCL2001B11.b & $\begin{array}{l}\text { Glycosyl hydrolases family } 18 \text { (probable chitinase } \\
\text { or xylanase inibitor)(UNIPROT) }\end{array}$ & 0.311 & -0.021 & 0.275 & -0.039 & 0.019 & carbohydrate metabolic process & & $\begin{array}{l}\text { hydrolase activity, hydrolyzing } \\
\text { O-glycosyl compounds }\end{array}$ & $\begin{array}{c}\text { chitinase } \\
{[E C: 3.2 .1 .14] ; E 3.2 .1 .14}\end{array}$ \\
\hline 34 & SCCCCL4003F09.g & $\begin{array}{l}\text { Glycosyl hydrolases family } 18 \text { (probable chitinase } \\
\text { or xylanase inibitor)(UNIPROT) }\end{array}$ & 0.235 & -0.004 & 0.164 & -0.231 & 0.662 & $\begin{array}{l}\text { carbohydrate metabolic process;cellular process;response to abiotic } \\
\text { stimulus;response to stress;single-organism process }\end{array}$ & & $\begin{array}{l}\text { hydrolase activity, hydrolyzing } \\
\text { O-glycosyl compounds }\end{array}$ & $\begin{array}{c}\text { chitinase } \\
{[E C: 3.2 .1 .14] ; E 3.2 .11 \cdot 14}\end{array}$ \\
\hline 35 & SCLRT1020A08.g & $\begin{array}{l}\text { Probable alpha-glucosidase Os0600675700 } \\
\text { OS=Oryza sativa subsp. japonica } \\
\text { GN=0s06g0675700 PE=1 SV=1 (UNIPROT) }\end{array}$ & 0.331 & -0.098 & 0.310 & -0.259 & 0.613 & $\begin{array}{l}\text { plant-type cell wall biogenesis; plant-type cell wall organization; xylan } \\
\text { catabolic process; xyloglucan metabolic process }\end{array}$ & $\begin{array}{l}\text { apoplast; chloroplast; cytosol; } \\
\text { plant-type cell wall; plasmodesma; } \\
\text { vacuole }\end{array}$ & $\begin{array}{l}\text { alpha-N-arabinofuranosidase } \\
\text { activity;yylan 1,4-beta- } \\
\text { xylosidase activity;yyloglucan } \\
\text { 1,6-alpha-yylosidase activity }\end{array}$ & $\begin{array}{l}\text { alpha-glucosidase } \\
\text { [EC:3.2.1.20];malz }\end{array}$ \\
\hline
\end{tabular}




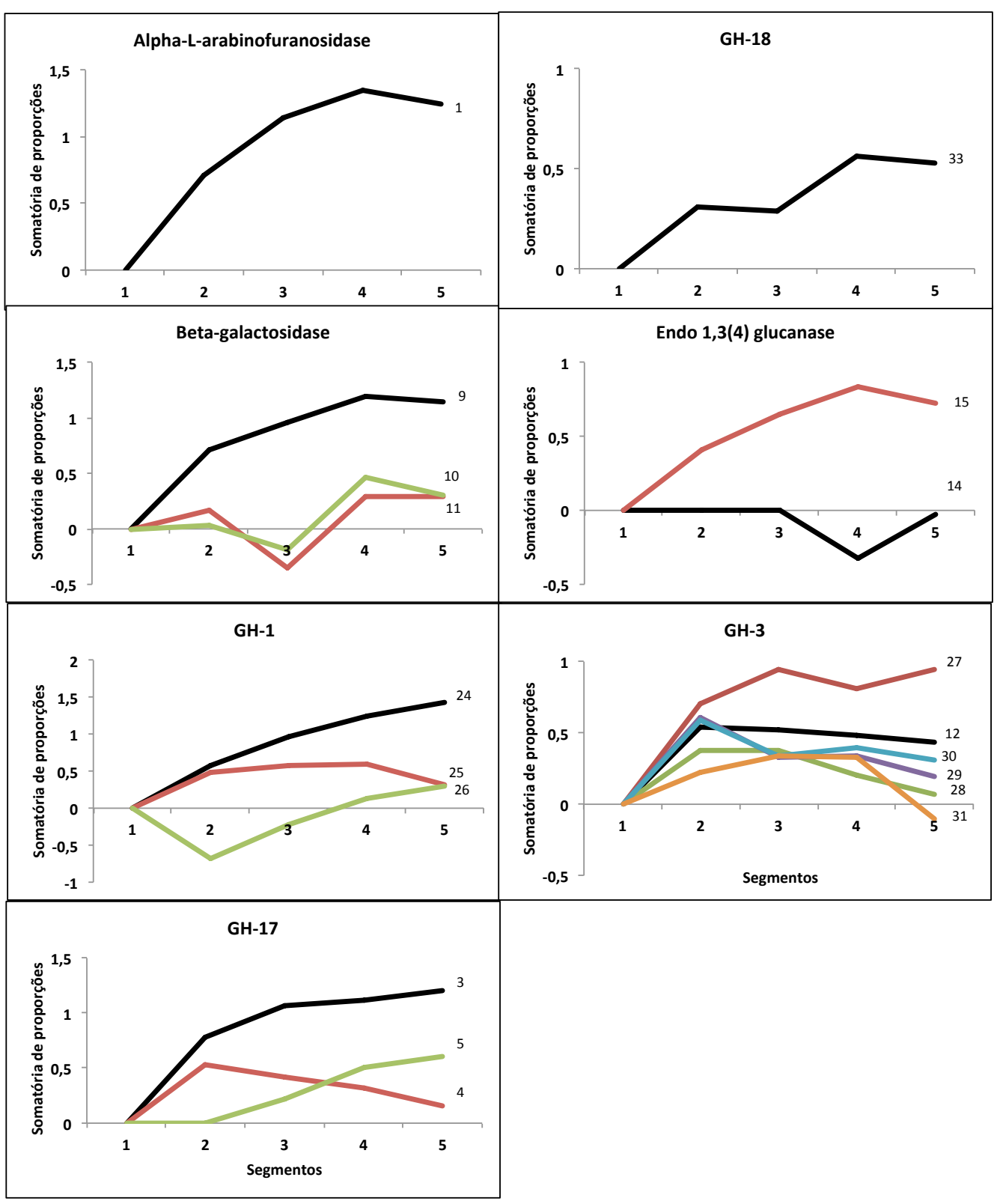

Figura 23. Principais mudanças cumulativas entre os segmentos de raízes de cana de açúcar durante a formação do aerênquima. Dados foram calculados para as proteínas de hidrólise da parede celular e normalizados a partir das razões obtidas a partir do segmento 1. Números em cada amostra representam as proteínas citadas na Tabela 4 . O segmento 1 passou a ser o controle sempre iniciando com 0 , quando positivo traduz que há aumento das enzimas entre os segmentos e quando negativo/diminui indica que houve redução da concentração dessas proteínas (Mediana de 5 indivíduos).

As proteínas supostamente relacionadas à PCD (83 proteínas) encontram-se listadas no Anexo 5, que foram selecionadas obtidas a partir de toda a literatura de PCD em plantas. Contudo apenas 4 classes dessas proteínas são mais estudadas em relação a PCD em plantas: calmodulinbinding protein, calreticulin, cytochrome $c$ e $b$ e catepsin $B$. Sendo assim as calmodulinas e 
calreticulinas responsáveis pela primeira percepção da sinalização via cálcio e PCD em plantas, foram analisadas a distribuição das proteínas ao longo dos segmentos, sendo encontradas três calmodulinas (SCCCCL2001B01.b; SCVPLR1049C09.g) e 2 calreticulinas (SCSGST1072D03.g; SCEPLR1051D05.g) que apresentaram diferenças significativas. O padrão de ocorrência de calreticulinas e calmodulinas mostrou redução na proporção destas proteínas na transição do segmento 1 para o 2, sendo os níveis de uma calmodulina constante. Isso pode indicar que o processo de morte celular programada se inicia já nos primeiros segmentos, ou seja, nos estágios iniciais de formação do aerênquima. Citocromos c e b (SCUTLR1058A12.g e SCCCLR1001H04.g) e a catepsin B (SCCCLB1023F09.g) também são observados durante a morte celular programada, neste caso os dados também foram significativos, aumentando a quantidade relativa principalmente no segmento 2 (Figura 24).

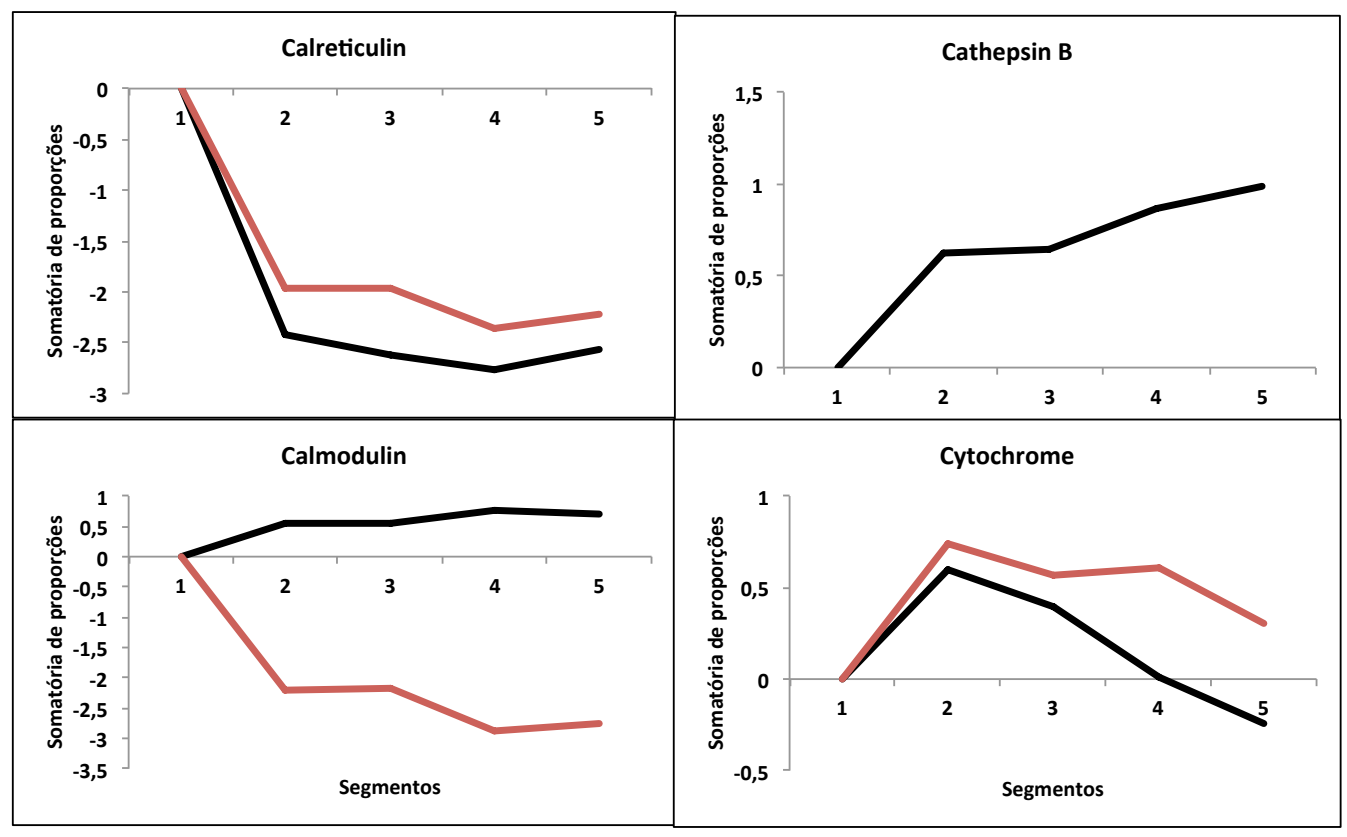

Figura 24. Principais mudanças cumulativas entre os segmentos de raízes de cana de açúcar durante a formação do aerênquima. Dados foram calculados para as proteínas relacionadas a morte celular programada (PCD) e normalizados a partir das razões obtidas a partir do segmento 1 . O segmento 1 passou a ser o controle sempre iniciando com 0 , quando positivo traduz que há aumento das enzimas entre os segmentos e quando negativo/diminui indica que houve redução da concentração dessas proteínas (Mediana de 5 indivíduos).

Outras proteínas que podem estar relacionadas à PCD foram observadas ao longo dos segmentos, como ATP synthase subunit $\alpha$, cystein protease, cytochrome $b$ e $c$, enolases, heat shock proteins, proteínas relacionadas ao metabolismo de jasmonato (jasmonate e jasmonic acid), 
ascorbate peroxidase e superoxide dismutase, sugerindo que PCD está ocorrendo ao longo dos segmentos (Anexo 5). Diversas dessas proteínas elencadas nessa análise foram descritas em trabalhos que relacionaram fatores externos, como alagamento e seca na indução da PCD e formação de aerênquima (Kaufmann e Hengartner 2001, Ahsan et al. 2007, Swidzinski et al. 2004, Hashiguchi et al. 2009, Komatsu et al. 2009, Nanjo et al. 2010).

\section{Sacarificação dos segmentos de raiz}

Visto que as paredes celulares são modificadas ao longo da formação do aerênquima, para quantificar a suscetibilidade dos polissacarídeos à hidrólise enzimática foram realizados ensaios de sacarificação nos diferentes segmentos de raízes de cana de açúcar. Os resultados mostraram que o pré-tratamento com $\mathrm{NaOH}$, em relação ao pré-tratamento com água quente, resulta em maior acessibilidade às enzimas do coquetel, visto que houve maior liberação de açúcares em todos segmentos e maior acesso dessas hidrolases à celulose (Figura 25). Dentre as amostras pré-tratadas com água quente, os segmentos 1 e 2 apresentaram maior sacarificação em relação aos demais, devido a maior solubilidade dos polissacarídeos presentes nestes segmentos. Já nos segmentos prétratados com $\mathrm{NaOH}$ foi visto que há uma diminuição no poder de sacarificação principalmente no 1 em relação aos demais (Figura 25).

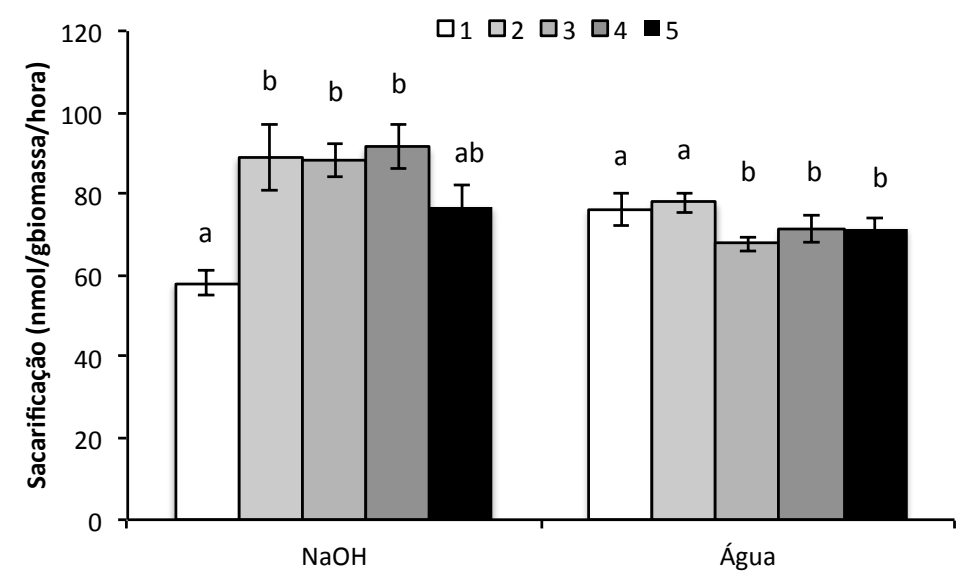

Figura 25. Sacarificação em diferentes pré-tratamentos ( $\mathrm{NaOH}$ e água) nos segmentos (1 a 5) das raízes de cana de açúcar. Dados representam média e o erro padrão $(n=5)$. Letras diferentes representam significância pelo teste ANOVA-Tuckey $(p<0,05)$ entre segmentos em cada pré-tratamento, valor de $\mathrm{P}$ para $\mathrm{NaOH}=0,003$ e água $=0,002$. 


\section{DISCUSSÃO}

Recentemente, estudos que abordam uma ampla variedade dados, que avaliam desde aspectos relacionados ao padrão transcricional até o perfil de produção de proteínas vêm sendo intensificados. No caso dos estudos mais aprofundados em proteômica, o principal objetivo é chegar a conclusões a respeito da dinâmica do metabolismo protéico (Nelson et al. 2014). Neste sentido, este trabalho teve como principal objetivo estudar os mesmos elementos supracitados (expressão gênica, proteômica e atividade enzimática) referentes às glicosil hidrolases de parede celular e proteínas relacionadas à morte celular programada que possivelmente participam do processo de formação do aerênquima em raízes de cana de açúcar.

Considerando a teoria de que nas plantas há módulos de degradação da parede celular e que estes módulos podem ocorrer da mesma forma dependendo do tecido em que estão localizados (Grandis et al. 2014), os dados deste trabalho vem mostrar que no aerênquima de raízes de cana de açúcar ocorre o mesmo processo quando comparado com a mobilização de parede celular de reserva, amadurecimento de frutos, interação planta-microrganismo e abscisão foliar. Todos esses processos levam a modificação celular, utilizando a hidrolise da parede. Os módulos que compõe esses processos são: (1) percepção de um sinal, (2) separação celular, (3) expansão celular, (4) PCD, (5) hidrólise ou afrouxamento de hemiceluloses e celulose, (6) hidrólise de celulose (ver Grandis et al. 2014 em anexo).

Os dados obtidos nesse estudo mostram que muitos desses módulos foram verificados através da análise de expressão gênica e de proteínas de algumas hidrolases, bem como a atividade de algumas glicosil hidrolases, principalmente de pectinases, que possibilitou a compreensão das modificações nos polissacarídeos da parede durante a formação do aerênquima observadas por Leite (2013).

A formação do aerênquima ocorre centripetamente no córtex das raízes de cana de açúcar (Leite, 2013), se iniciando entre o segundo e o terceiro centímetro da raiz a partir do ápice e concluindo-se no quinto centímetro. (Figuras 2 e 7). As proporções de ocupação do córtex pelos 
espaços abertos pelo aerênquima observadas neste trabalho corroboram os dados produzidos por Leite (2013), que reportou a porcentagem de cerca de 19\% de aerênquima no córtex no terceiro segmento de raiz, totalizando $40 \%$ quinto centímetro. O que foi observado neste e nos demais estudos que envolvem aerênquima em cana de açúcar (Tetsushi e Karim 2007; Begum et al. 2013) é que não ocorre indução a formação do mesmo por fatores ambientais (como ocorrem em raízes de milho), sendo um processo muito similar ao de formação do aerênquima em arroz, considerado constitutivo, isto é, faz parte do desenvolvimento da raiz (Webb e Armstrong 1983; Jackson et al. 1985).

\section{Percepção do sinal e morte celular programada}

Antes da formação do aerênquima, postula-se que inicialmente há uma sinalização via etileno para que, na sequência, ocorra um aumento citosólico de $\mathrm{Ca}^{2+}$ para acionar a PCD (Kawai et al. 1998; Morgan e Drew 2004). Proteínas responsivas a cálcio, requeridas para a sinalização, sofrem alterações conformacionais após interação com este íon, ativando as suas respectivas respostas à montante (Harmon et al. 2001, DeFalco et al. 2010) levando à ativação de toda a cascata de sinalização para PCD e consequente à formação do aerênquima. A partir dos dados de expressão gênica, foi observado um aumento no acúmulo de transcritos referentes a essas proteínas a partir do segmento 2 (Figura 11).

Dentre as proteínas cuja expressão foi quantificada, duas destas codificam para uma calmodulin-binding protein que apresentaram perfis opostos. Uma delas possui acúmulo de proteínas que se mantem constante entre os segmentos enquanto a outra apresenta redução ao longo dos segmentos. Transcritos referentes calreticulin aumentaram após o segmento 1 , indicando que possa estar relacionado com as proteínas que permaneceram constantes ao longo dos segmentos, ou ainda devido a diminuição dessas proteínas há a sinalização para que haja a transcrição de novas proteínas (Figura 11). Quando se fala em transcritos, a sinalização é muito rápida e pode ser que muitas vezes seja até instantânea (short-term) para que mRNAs sejam ativados e transcritos, enquanto que para as proteínas o aumento de expressão é de longa duração 
(long-term) (Buchanan et al. 2000) fazendo com que a correlação entre transcritos e proteínas seja de difícil análise. O relevante no caso das duas proteínas mencionadas acima, assim como a presença de outras proteínas como o cytochrome $b$ e $c$ e a cathepsin $B$, é que tanto os transcritos como as proteínas foram encontrados ao longo dos segmentos o que sugere que a sua presença esteja relacionada com o processo de morte celular programada (Figura 11 e Anexo 5).

Outro indicio de que esteja ocorrendo PCD é a fragmentação de DNA (Reed 2000; Gunawardena et al., 2001a) que pode ser inferido pela técnica de Terminal deoxynucleotidyl transferase dUTP nick end labeling (TUNEL). Esta técnica foi utilizada por Leite (2013) e confirmou a existência de PCD nos segmentos de raiz de cana de açúcar, que se inicia a partir do segmento 2, com um ligeiro aumento na quantidade até o $4^{\circ}$ segmento. $O$ aumento do número de transcritos referentes à proteínas ligantes à cálcio no segmento 2 corrobora a intensificação de $P C D$ no mesmo segmento de raiz visto pela fragmentação dos núcleos. Além destes transcritos, dados do presente trabalho também sugerem um aumento da expressão de outras proteínas relacionadas à PCD a partir do segmento 2 (Figura 24 e Anexo 5), o que indica que parte dos módulos estão ocorrendo (Grandis et al. 2014). Outra evidência de PCD também obtida por Leite (2013) foi obtida através de análises por microscopia de transmissão, onde foi evidenciado o colapso das células, incluindo a degradação de organelas e desaparecimento do citoplasma nas regiões de aerênquima.

Assim, os dados obtidos no presente trabalho acrescentam mais uma dimensão que sugere fortemente que PCD ocorra ao mesmo tempo em que o aerênquima se forma em cana de açúcar. Uma série de proteínas que poderia estar também relacionada com a PCD durante a formação do aerênquima encontra-se no Anexo 5. Estas ainda terão que ser estudadas com maior profundidade a fim de verificar se há correlação ou não com $P C D$, mas pelo que se conhece da literatura (Kaufmann e Hengartner 2001, Ahsan et al. 2007, Swidzinski et al. 2004, Hashiguchi et al. 2009, Komatsu et al. 2009, Nanjo et al. 2010, Rahji et al. 2011) é provável que sim.

O processo de PCD ocorre em paralelo com modificações em pectinas, hemiceluloses e celulose, durante os módulos de separação celular, expansão e degradação de polissacarídeos. Porém, até o momento, em cana de açúcar não se sabia quais hidrolases de parede celular 
poderiam estar relacionadas com o processo de modificação nas paredes celulares que, segundo Leite (2013) e Grandis et al., (2014) acaba gerando um compósito formado por parede modificada e que aparentemente dá sustentação às cavidades formadas pelo aerênquima nas raízes .

\section{Glicosil hidrolases nas modificações da parede celular durante a formação do}

\section{aerênquima}

Apesar da maioria dos trabalhos tratar a formação de aerênquima lisígeno como um processo que leva à degradação completa da parede celular (Kawase 1974, 1979, Gunawardena et al. 2001b, Morgan e Drew 2004), os dados deste trabalho acoplados aos dados de microscopia de transmissão e anticorpos monoclonais para polissacarídeos de parede celular (Leite 2013) apontam para uma modificação da composição e da arquitetura da parede celular e não de uma completa degradação da parede. Em outras palavras, fica cada vez mais claro que as transformações na parede têm também a função de gerar uma estrutura física que deve exercer um papel biológico importante na condução de gases através dos espaços de ar encontrados no aerênquima.

Levando-se em conta as glicosil hidrolases de parede celular citadas nos trabalhos de Jackson e Armstrong (1999) (expansinas, celulases, XTH e pectinases), a hipótese deste trabalho é de que haveria uma ordem de ataque das glicosil hidrolases à parede celular, no intuito de facilitar o acesso aos polissacarídeos. Esta sequência se iniciaria com a degradação de pectinas da lamela media. Dentre os trabalhos que suportam essa hipótese está o de Gunawardena et al. (2001b), que verificou a modificação de pectinas em uma fase muito precoce da morte celular em raízes de milho, assim como Leite (2013), que também observou que as pectinas presentes nas junções triangulares desapareciam ao longo da formação do aerênquima de cana. Neste contexto, foi observado que o padrão de expressão de genes que codificam para pectinases segue positivamente a formação do aerênquima. Este é o caso dos transcritos de endo-poligalacturonase e da $\beta$ galactosidase cujos acúmulos se iniciam a partir do segmento 2 e se eleva linearmente até o segmento 5 (Figuras 15 e 17). 
Os dados referentes à atividade enzimática indicam também uma degradação inicial das pectinas que aumenta até o segmento 3 observado pelo aumento da atividade específica dos substratos: $\alpha$-arapi, $\alpha$-arf e $\beta$-gal. Essas atividades sugerem ataque a arabinanos e galactanos presentes nas pectinas (Figura 9). Na proteômica não foi observado um aumento de endopoligalacturanases ao longo dos segmentos que corroborasse a degradação de homogalacturonanos. Contudo, foi observada a presença pontual delas, que foram removidas da análise por causa das restrições adotadas. Por isto, as endopoligalacturonases são apenas listadas como proteínas totais encontradas nas raízes (Anexo 2).

Já os transcritos e proteínas referentes às enzimas responsáveis pela remoção de cadeias laterais das pectinas, como é o caso das $\beta$-galactosidases e a $\alpha$-arabinofuranosidases (Tabela 4 e Figura 23), acumularam-se nos segmentos 2 e 4 e uma das proteínas de $\beta$-galactosidase aumenta linearmente a partir do segmento 2 (Figura 23). Foi identificada também uma tendência de acúmulo de transcritos e de proteínas ao longo dos segmentos de uma $\alpha$-galactosidase e uma $\alpha$ glucosidase, que podem estar envolvidas no processo de degradação de outros polissacarídeos de parede, como galactomananos e xiloglucanos respectivamente (Tabela 4). Observando o conjunto de dados que convergem para degradação de pectinas juntamente com dados de composição da parede (Leite 2013), é possível inferir que a degradação das pectinas está diretamente envolvida no processo de formação de aerênquima nas raízes de cana de açúcar, bem como na separação das células como proposto na teoria dos módulos (Grandis et al. 2014).

Por ser muito solúvel, o $\beta$-glucano é conhecido como um polissacarídeo de transição, sintetizado em tecidos em alongamento e que desaparece quando o alongamento celular diminui (Carpita 1996, Kim et al. 2000). Contudo existem controvérsias, já que o $\beta$-glucano pode ser depositado na parede contribuindo para o afrouxamento e permitindo a expansão celular (Buckeridge et al. 2004). Portanto, é possível que a retirada do $\beta$-glucano da parede celular durante a formação do aerênquima possa tornar a parede mais rígida e menos acessível a outras glicosil hidrolases. Isso é observado no perfil dos genes e de proteínas que evidenciam um maior nível de glicosil hidrolases que atacam esse polissacarídeo entre os segmentos 2 e 3 (Figuras 18 e 19 e 
Tabela 4). Posteriormente à retirada do $\beta$-glucano (Leite 2013) a formação do aerênquima é concluída, sendo este polissacarídeo aquele cuja variação melhor se relaciona temporalmente com a formação do aerênquima.

O padrão de expressão de genes que codificam para $\beta$-1,3-glucanase (GH17) (Figura 18), como também pela presença de proteínas que correspondem às endo-1,3;1,4 $\beta$-glucanase elevada no segmento 2 (Tabela 4 e Figura 23) sugerem possível ataque ao à calose e ao $\beta$-glucano na parede celular desses segmentos. Conforme observado por Leite (2013), no quinto segmento de raiz não foi verificada a presença de $\beta$-glucano. Visto que a família de GH17 contém enzimas distintas mas com uma estrutura de alta similaridade: $\beta-1,3$ glucanases e $\beta-1,3 ; 1,4$ glucanases (Lashbrook et al. 1994), que sugere que estas possuem um ancestral comum. A $\beta-1,3$ glucanase é uma proteína abundante encontrada nas plantas superiores e é encontrada no desenvolvimento, fertilização, mobilização de reservas do endosperma, na divisão celular (Stone e Clarke 1992), como resposta ao ataque de patógenos (Bucher et al. 2001) e relacionada a degradação de calose (Worrall et al. 1992). Ainda alguns estudos sobre calose (um $\beta-1,3$ glucano) mostram a importância desse polissacarídeo na capacidade de transferência de substâncias intracelulares através dos plasmodesmos. Portanto, a degradação de calose pode ser um indício de que a comunicação entre as células formadoras do aerênquima esteja aumentando. De fato, genes que codificam para enzimas da classe GH17 têm sido demonstrado participar ativamente do processo de tráfego intercelular em Arabidopsis (Levy et al. 2007, Simpson et al. 2009).

A presença de proteínas relacionados às enzimas $\beta-1,3 ; 1,4$ glucanases, encontradas também nos segmentos de raiz (Tabela 4 e Figuras 23) e que degradam o $\beta-1,3 ; 1,4$ glucano durante o alongamento de tecidos vegetativos em gramináceas (Cosgrove 1999, Hoj e Fincher 1995), sugere que as enzimas produzidas possivelmente estão relacionadas a expansão celular das raízes. Sendo assim, devido a esses diversos processos nos quais a família GH17 parece participar, pode-se sugerir que os membros dessa família encontrados nos segmentos de cana de açúcar participem da formação do aerênquima. 
Como a região da raiz em estudo compreende principalmente uma região meristemática (segmento 1), seguida de uma região em desenvolvimento, visto ainda pela presença de grande quantidade de $\beta$-glucanos e enzimas da família GH17, onde a formação dos tecidos ocorre concomitantemente com a formação do aerênquima lisígeno, foi observado um padrão semelhante de transcritos de celulose sintase nos 5 segmentos indicando que há parede ainda em formação (Figura 10). Outra evidência que corrobora esta hipótese é detecção de alta expressão de transcritos de expansinas no segmento 1 (Figura 14) e entre as proteínas a expansina é observada sendo constante entre os segmentos (Tabela 4). O padrão de expressão de genes que codificam para expansinas foi de acúmulo no primeiro segmento, decaindo no segundo e seguido de um aumento marcante do terceiro segmento em diante. As expansinas podem estar atuando, neste caso, no afrouxamento e na expansão da parede celular, etapa requerida para que haja o ataque de glicosil hidrolases à parede, e que é outra etapa da teoria de módulos (Grandis et al. 2014). Em outros processos, como o amadurecimento de frutos, tem sido observada a regulação positiva da expressão de genes de expansinas em resposta ao etileno, promovendo a extensibilidade da parede (Rose et al. 2000). Entretanto, nas raízes de cana de açúcar as oscilações nos níveis da proteína correspondente não foram estatisticamente significativas, evidenciando um possível descontinuidade entre os processos de expressão gênica e tradução (Figura 14 e Tabela 4).

A expressão de genes que codificam para XTH também foi observada ao longo dos segmentos, mostrando três padrões transcricionais. Dois transcritos de XTH acumularam-se mais marcadamente no segmento 1 , possivelmente por esta ser uma região de intensa divisão, diferenciação e expansão celular. Outro transcrito referente também à XTH apresentou níveis constantes ao longo de todos os segmentos. Por último, foi avaliado o padrão transcricional de um gene que codifica para uma XTH com sequência primária com alta similaridade à identificada no trabalho de aerênquima em raízes de milho (Rajhi et al. 2011). Em cana de açúcar tal transcrito apresentou forte acúmulo do segmento 2 até o 5 (Figura 13), mas na análise proteômica não foi identificada nenhuma XTH, possivelmente pela dificuldade de extração dessa proteína. 
As proteínas de XTH compõem o grupo de genes da subfamilia GH16 de acordo com a classificação do CAZy (Carbohydrate-Active enZymes - Cantarel et al., 2009) e apresentam uma grande diversidade de substratos específicos como membros de ligações $\beta$ - 1,3 ou $\beta-1,4$ de vários glucanos e galactanos, porém bem distantes da família de celulases GH7 (Michel et al. 2001, Eklof, 2010) e mais próximas das hidrolases de bactérias e fungos $\beta-1,3 ; 1,4$-glucanos CRH (para Congo Red Hypersensitive) relacionados com quitina, $\beta-1,6$ - e $\beta-1,3-$ glucanos (Cabib et al. 2008). Devido a essa similaridade entre as familias de proteínas, duas das endo 1,3;1,4 beta-glucanase foram observadas.

Leite (2013) observou aumento de deposição de xiloglucano e arabinoxilanos no córtex durante a formação do aerênquima, sugerindo o requerimento de enzimas como a XTH. Por outro lado, a quantidade de xiloglucano em cana-de-açúcar é relativamente baixa por se tratar de uma parede celular do tipo II (Carpita 1996, De Souza et al. 2013) dados apontam que gramíneas apresentam aproximadamente $5 \%$ de xiloglucano, enquanto que arabinoxilanos e $\beta$ - glucanos são dominantes (Hoffman et al. 2005, Cavalier et al. 2008, Fincher 2009, Hsieh e Harris 2009). Assim, é possível especular que a quantidade de XTH necessária para remodelar este carboidrato seja igualmente baixa e daí o padrão de expressão gênica ser visível enquanto o de expressão de proteínas não o ser. Mais especificamente, é possível que os níveis de XTH sejam baixos o suficiente para não ultrapassar o limiar de dectecção do espectrômetro, ou ainda não apresentar uma sequência de peptideos que tenha identificação com o banco de dados e com as análises realizadas.

XTH e expansinas são conhecidas como proteínas associadas à expansão da parede celular em plantas (Rose et al. 2002, 2000). No caso da formação do aerenquima em cana verifica-se que a expansão celular ocorre inicialmente, já entre os segmentos 1 e 2, sendo possível que os padrões de expressão gênica e de proteínas observados estejam diretamente relacionados ao processo de expansão celular que, segundo Grandis et al. (2014) seria mais um dos módulos funcionais que antecede a formação do aerenquima em raízes de cana.

A parede de cana de açúcar possui em sua composição também arabinoxilanos, os quais ocorrem em maiores proporções em relação a todas as outras hemiceluloses (De Souza et al. 2013). 
Sabe-se que diferenças na estrutura fina dos arabinoxilanos podem influenciar no modo de ação das enzimas (Buckeridge e De Souza, 2014), onde a redução de substituições com radicais acetil, ácidos ferúlicos, arabinose e ácido glucurônico diminuem a acessibilidade aos polissacarídeos além de requerer menor quantidade de enzimas para sua completa hidrólise (Mortimer et al. 2010). Sendo assim, possíveis modificações nas ramificações dos arabinoxilanos, sugeridas pela detecção de glicosil hidrolases específicas para estes polissacarídeos, podem estar diretamente correlacionados com a degradação de algumas ramificações e da mudança estrutural das paredes, contribuindo na formação no aerênquima das raízes de cana de açúcar. A presença de transcritos das xilosidases (Figura 23) e proteínas relacionadas à modificação/degradação como xilosidases e $\alpha$-arabinofuranosidases da família GH3 (Tabela 4 e Figura 23) foram verificadas ao longo dos segmentos, com padrão de acúmulo a partir do segmento 2. Essas enzimas são capazes de hidrolisar tanto L-Ara and D-Xyl presentes tanto em hemiceluloses como pectinas, sendo consideradas como enzimas bifuncionais (Montes et al. 2008). Um aumento destas atividades enzimáticas foi observado principalmente no segmento 3 , além do aumento de transcritos de $\beta$ xilosidase no segmento 2 (Figura 9). Já o transcrito de $\alpha$-arabinofuranosidase acumula-se a partir do segmento 3 (Figura 16) coincidindo com pico de deteç̧ão da proteína (segmentos 3 e 4) e atividade enzimática (Figura 9) correspondentes.

Em conjunto esses dados apontam para a degradação e uma possível modificação do arabinoxilano presente na parede. Foi observado que há um aumento nos xilanos mais aderidos a parede ao longo dos segmentos, enquanto que alguns dos arabinoxilanos foram degradados (Leite 2013), o que corrobora os dados de transcrição, proteínas e atividade reportados neste trabalho. A presença de expressão de um provável inibidor de xilanases (GH18), cuja proteína expressa aumenta gradativamente ao longo dos segmentos em direção ao segmento 4 (Tabela 4, Figura 23) sugere que a atividade enzimática sobre arabinoxilanos possa ser controlada através da inibição dessas hidrolases.

No presente trabalho, o padrão de transcritos de celulase e de uma $\beta$-1,4-glucosidase evidenciaram acúmulo no segundo segmento, permanecendo constantes nos demais (Figura 19). 
Contudo a celulose foi um dos componentes da parede cuja proporção mais aumentou ao longo dos segmentos, possivelmente não só pelo desenvolvimento do cilindro vascular, como também em razão da deposição de celulose ao redor do espaços de ar formados no tecido (Leite 2013). Na análise proteômica também foram identificadas glicosil hidrolases da família GH1 na qual estão inseridas as $\beta$-glucosidases (Tabela 4), que podem estar agindo no ataque à celulose na parede, como visto por Kawase $(1974,1979)$ em células corticais do estame de girassol tratadas com celulase. Contudo essas celulases podem estar agindo apenas na modificação da parede, participando da formação de compósitos de parede celular contendo celulose, (Leite 2013). Isto contraria o que se esperava com base na literatura, onde a celulose é dita ser completamente degradada (Horton e Osborne 1967, Drew et al. 1979, Subbaiah e Sachs 2003). Em aerênquima de cana, a celulose pode estar sendo travada pela produção de lignina que impede o acesso a essas cadeias de glicose. Estas medidas não puderam ser feitas e portanto este hipótese carece de verificação.

No entanto, foi observada a expressão de genes que codificam para lacases a partir do segmento 2, o que indica que pode ter havido modificações nas ligninas nos tecidos do córtex e também do cilindro vascular, possivelmente travando a parede em pontos específicos e impedindo a ação de outras glicosil hidrolases (Figura 12 e Anexo 2). Esta hipótese tem que ser considerada com parcimônia, uma vez que o a função da lacase ainda não foi demonstrada claramente. Várias linhas de pesquisa sugerem o seu envolvimento na biossíntese de lignina, principalmente em estudos com lignificação em madeira. Outros baseiam-se na sua capacidade em oxidar precursores de lignina e a sua localização na parede celular durante a lignificação do xilema (Davin et al. 1992, Driouich et al. 1992, Sterjiades et al. 1992, Bao et al. 1993, McDougall e Morrison 1996, Ranocha et al. 2002). Contudo será necessário quantificar a lignina nos segmentos para verificar se o teor de lignina muda ao longo da raiz.

Visto que foram alteradas algumas das hemiceluloses pela expressão de transcritos e proteínas de parede e também houve aumento a expansão celular (Figuras 14 e 13, Tabela 4), observado microscopicamente por Leite (2013) e pela transcrição de XTH e expansinas observadas 
neste trabalho, é possível especular que a teoria modular empregada para as hemiceluloses nos diferentes processos fisiológicos de modificações da parede das plantas se aplica para a formação de aerênquima lisígeno em cana de açúcar. Contudo os dados de aumento de celulase não resultam em degradação de celulose como é suposto que aconteça (Figura 19). O que parece haver é somente um rearranjo da celulose com o auxilio dessas enzimas, o que contribui para a formação um compósito de celulose junto aos xilanos e xiloglucano (Leite 2013). Este processo resulta na formação dos espaços de ar, que dividem as células vivas do córtex com as células que morreram para a formação do aerênquima (Figura 7).

Os dados deste trabalho mostram que as glicosil hidrolases são sintetizadas principalmente entre os segmentos 2 a 3 . É relevante salientar que o aerênquima é resultado da remoção seletiva de grupos específicos de células do córtex, logo as glicosil hidrolases atacam apenas as células-alvo e são todas produzidas antes mesmo da formação completa do aerênquima. Isso pode ser resultado da composição da parede celular especificamente dessas células, que devem possuir polissacarídeos modificados que permitem o acesso dessas enzimas. Neste contexto, a fim de verificar a suscetibilidade das paredes (ao longo dos segmentos de raiz) ao ataque das glicosil hidrolases, foi realizado um experimento de sacarificação da biomassa dos segmentos de raiz.

\section{Acessibilidade das glicosil hidrolases à arquitetura da parede celular dos segmentos de}

\section{raiz}

Com a finalidade de verificar a suscetibilidade da parede celular destes segmentos de raiz à ação das glicosil hidrolases estudadas neste trabalho, foram efetuados ensaios de sacarificação, utilizando coquetéis enzimáticos contendo diversas hidrolases. Estes foram aplicados à parede celular após pré-tratamentos com água quente e com álcali (Figura 25). Os resultados de sacarificação mostraram que o pré-tratamento com $\mathrm{NaOH}$ possibilita a hidrólise com maior facilidade do que o pré-tratamento com água quente. Diante da maior concentração de celulose nos segmentos 3, 4 e 5 (Leite 2013) foi possível obter uma maior sacarificação pela presença de maiores quantidades de glicose no material oriundo destes segmentos. A maior sacarificação com o 
pré tratamento com o álcali se dá possivelmente devido ao maior acesso a parede celular obtido após a retirada de ésteres de acetila e ácido ferúlico (Silva 2005, Crivellari 2012, De Souza 2011, De Souza et al. 2013), o que aumenta o acesso das xilanases aos xilanos e assim abre caminho para a hidrólise da celulose e xiloglucano, principalmente do segmento 2 ao 4 (Figura 25).

Neste contexto, polissacarídeos e alguns carboidratos mais solúveis estão presentes principalmente nos primeiros segmentos das raízes de cana de açúcar (segmentos 1 e 2), o que faz com que o tratamento com água seja mais efetivo para verificar a sacarificação do que o tratamento com $\mathrm{NaOH}$. Neste sentido, polissacarídeos de parede celular como as pectinas mais ramificadas e o $\beta$-glucano estão em maior quantidade nesses segmentos iniciais (Leite 2013). No segmento 1 essa proporção é maior por se tratar de uma região meristemática com alta taxa de divisão celular, necessitando de maior quantidade de sacarose livre para o desenvolvimento, visto pelo aumento da proteína invertase neste segmento (Tabela 4). Já no que diz respeito ao $\beta$ glucano, apesar de característico de paredes do tipo II como um polissacarídeo de transição (Carpita 1996, Kim et al. 2000), reforçamos a conclusão de Leite (2013) que a degradação deste polissacarídeo é concomitante com a formação do aerênquima. Este não é degradado no cilindro vascular e nas diferentes distâncias do ápice analisadas, inclusive onde os tecidos já estão completamente desenvolvidos.

Integrando os dados dos dois pré-tratamentos realizados é possível inferir o que pode estar ocorrendo entre as glicosil hidrolases estudas com a composição da parede das raízes de cana. Ao solubilizar esses polissacarídeos em água (o que simula uma condição da planta in vivo) as hidrolases do coquetel têm maior acesso a parede e outros componentes nos segmentos 1 e 2 principalmente, reduzindo nos demais segmentos, pois o acesso aos polissacarídeos foi reduzido. Entretanto, quanto o acesso a esses polissacarídeos foi facilitado com o pré-tratamento de $\mathrm{NaOH}$ foi visto uma maior sacarificação nos segmentos que antes não eram acessíveis pelo método de água quente.

Todavia, quando o pré-tratamento é realizado com $\mathrm{NaOH}$, que remove esses polissacarídeos mais solúveis durante o processo, é visto que nos segmentos 1 e 5 a sacarificação é 
menor em relação aos segmentos 2, 3 e 4 (Figura 25). O decréscimo na sacarificação pode estar relacionado à maior concentração de pectinas fortemente aderidas a celulose e consequentemente a uma menor ação das enzimas nesse segmento, como visto em Lionetti et al. (2010). Estes autores observaram que a redução na concentração de certas pectinas da parede celular leva à maior sacarificação de biomassa de plantas transgênicas de Arabidopsis modificadas, devido ao fato dessas pectinas estarem bloqueando o acesso das glicosil hidrolases a outros polissacarídeos (Lionetti et al. 2010).

No segmento 5, a menor sacarificação pode estar relacionada à formação de um compósito de celulose e hemiceluloses (arabinoxilano e xiloglucano) (Leite 2013), que estaria influenciando no acesso da enzima à celulose. Já nos demais segmentos vimos que a sacarificação é maior, pois a partir do segmento 1 as pectinas passam a ser removidas do tecido (observado principalmente pela expressão gênica das pectinases, e por dados de composição da parede celular), dando espaço para as glicosil hidrolases agirem. Isso indica que as hipóteses sobre a existência de uma ação sequencial das enzimas (De Souza et al. 2012), e da consequente existência de módulos nos quais polissacarídeos específicos são atacados (Grandis et al. 2014) são possivelmente válidas para a formação do aerênquima em cana de açúcar, pois para ter acesso à celulose, arabinoxilano e xiloglucano a pectina e os $\beta$-glucanos precisam ser removidos.

\section{CONCLUSÕES E PERSPECTIVAS}

Apesar da maioria dos trabalhos tratar a formação de aerênquima lisígeno como degradação completa da parede celular (Kawase 1974, 1979, Gunawardena et al. 2001b, Morgan e Drew, 2004), os dados de glicosil hidrolases e proteínas relacionadas a PCD encontradas neste trabalho, acoplados aos dados de microscopia de transmissão e anticorpos monoclonais para polissacarídeos de parede celular (Leite 2013), apontam para uma modificação da composição e da arquitetura da parede celular e não de uma completa degradação da parede durante a formação do aerênquima lisígeno em raízes de cana de açúcar. 
Neste trabalho foi observado que glicosil hidrolases são produzidas nas raízes de cana de açúcar e estas atacam a parede celular, degradando principalmente as pectinas, pelo aumento da expressão de pectinases, endo-poligalacturanases, $\beta$-galactosidases, a-arabinosidases, seguido da degradação de $\beta$-glucano pela expressão de transcritos e proteínas de $\beta-1,3$ glicosidases e $\beta-1,4$ glucosidases. Modificações na estrutura de xilanos, arabinoxilanos e celulose também são sugeridas devido ao fato do aumento das glicosil hidrolases: $\beta$-xilosidase, a-arabinosidases, XTH e celulases ao longo dos segmentos de raiz.

Estes dados suportam a hipótese de que as plantas modificam a parede celular em diversas situações (como a formação de aerênquima) por seus próprios sistemas enzimáticos. O mesmo processo deve ocorrer para o aerênquima nas raízes onde os módulos são ativados endogenamente, resultando em alterações nas paredes (Grandis et al. 2014). Neste contexto, este trabalho vem contribuir com dados referentes às glicosil hidrolases produzidas pelas plantas, a fim de que, conhecendo quais hidrolases estão envolvidas nesses processos de modificação das paredes, seja possivel utilizá-las biotecnologicamente.

Os dados de sacarificação apontam que modificações da arquitetura da parede impostas pelas plantas impedem o ataque de suas próprias glicosil hidrolases, dificultando o acesso a celulose. Barreiras como a recalcitrância da biomassa podem ser rompidas, no intuito de modificar a produção de determinadas glicosil hidrolases e também de implementar modificações nos polissacarídeos da parede, dando acesso aos açúcares fermentáveis que estão disponiveis na parede celular, utilizando o pré-tratamento biológico proposto por Grandis e colaboradores (2014), sem utilizar grandes quantidades de energia para executar pré-tratamentos industriais, que gera alto custo e grandes quantidades de efluentes indesejáveis do ponto de vista ambiental. 


\section{REFERÊNCIAS BIBLIOGRÁFICAS}

Ahsan N, Lee DG, Lee SH, Lee KW, Bahk J, Lee BH. 2007. A proteomic screen and identification Waterlogging-regulated proteins in tomato roots. Plant Soil 295: 37-51.

Alcântara PHN, Dietrich SMC, Buckeridge MS. 1999. Xyloglucan mobilisation and purification of a (XLLG/XLXG) specific $\beta$-galactosidase from cotyledons of Copaifera langsdorffii. Plant Physiol. Biochem. 37: 653-663.

Arber A. 1920. Water Plants: A Study of Aquatic Angiosperms. Cambridge University Press, Cambridge.

Arikado H, Adachi Y. 1955. Anatomical and ecological responses of barley and some forage crops to the flooding treatment. Bulletin Faculty Agriculture, Mie University Tsu Mie 11: 1-29.

Arikado H. 1954. Different responses of soybean plants to an excess of water with special reference to anatomical observations. Proc. Crop Sci. Soc. Jpn. 23: 28-36.

Armstrong W, Drew MC. 2002. Root growth and metabolism under oxygen deficiency. In: Waisel Y, Eshel A and Kafkafi U, eds. Plant roots: the hidden half, 3rd edn. New York: Marcel Dekker, 729-761.

Armstrong W. 1979. Aeration in higher plants. Adv. Bot. Res. 7: 225-332.

Bao W, O'Malley DM, Whetten R \& Sederoff RR. 1993. A laccase associated with lignification in loblolly pine xylem. Science 260: 636-638.

Begum MK, Alam MR, Islam MS. 2013. Adaptive mechanisms of sugarcane genotypes under flood stress condition. World Journal of Agricultural Sciences 1: 056-064.

Boersema PJ, Raijmakers R, Lemeer S, Mohammed S, Heck AJR. 2009. Multiplex peptide stable isotope dimethyl labeling for quantitative proteomics. Nature Protocols 4: 484-494.

Bouranis DL, Chorianopoulou SN, Siyiannis VF, Protonotarios VE, Hawkesford MJ. 2003. Aerenchyma formation in roots of maize during sulphate starvation. Planta 217: 382-391.

Bradford MM. 1976. A rapid and sensitive method for the quantitation of microgram quantities of protein utilizing the principle of protein-dye binding. Anal Biochem. 72: 248-54.

Buchanan BB, Gruissen W, Jones RL. 2000. Biochemistry and molecular biology of plants. Charper 18. Signal perception and transduction p. 931-936. American Society of Plant Physiologists. 1367p.

Bucher GL, Tarina C, Heinlein M, Di Serio F, Meins Jr F, Iglesias VA. 2001. Local expression of enzymatically active class I beta-1,3-glucanase enhances symptoms of TMV infection in tobacco, Plant J. 28: 361-369.

Buckeridge MS, Rocha DC, Reid JSG, Dietrich SMC. 1992. Xyloglucan structure and post-germinative metabolism in seeds of Copaifera langsdorffii from savanna and forest populations. Physiologia Plantarum 86: 145-151.

Buckeridge MS, Rayon C, Urbanowicz B, Tiné MAS, Carpita NC. 2004. Mixed Linkage $(1 \rightarrow 3),(1 \rightarrow 4)-\beta-D-$ Glucans of grasses. Cereal Chemistry 81: 115-127.

Buckeridge MS. 2010. Seed cell wall storage polysaccharides: models to understand cell wall biosynthesis and degradation. Plant Physiol 154: 1-7.

Bush DS. 1995. Calcium relulation in plant cells and its role in signaling. Annual Review of plant physiology and Plant molecular biology. 103: 7-13. 
Borderies G, Jamet E, Lafitte C, Rossignol M, Jauneau A, Boudart G, Monsarrat B, Esquerré-Tugayé MT, Boudet A \& Pont-Lezica R. 2003. Proteomics of loosely bound cell wall proteins of Arabidopsis thaliana cell suspension cultures: A critical analysis. Electrophoresis 24: 3421-3432.

Buckeridge MS, De Souza AP. 2014. Breaking the Glycomic Code of Cell Wall Polysaccharides May Improve Second-Generation Bioenergy Production from Biomass. BioEnergy Research. DOI: 10.1007/s12155-014-9460-6.

Cabib E, Farkas V, Kosik O, Blanco N, Arroyo J, McPhie P. 2008. Assembly of the yeast cell wall Crh1p and Crh2p act as transglycosyl- ases in vivo and in vitro. J Biol Chem 283: 29859-29872.

Campbell R \& Drew MC. 1983. Election microscopy of gas space (aerenchyma) formation in adventitious roots of Zea mays L. subjected to oxygen shortage. Planta 157: 350-357.

Cantarel BL, Coutinho PM, Rancurel C, Bernard T, Lombard V, Henrissat B. 2009. The CarbohydrateActive EnZymes database (CAZy): an expert resource for glycogenomics. Nucleic Acids Res 37: D233-D238.

Carpita NC, McCann MC. 2008. Maize and sorghum: genetic resources for the bioenergy grasses. Trends Plant Science 13: 415-420.

Cavalari AA. 2009 Modificações da parede celular de frutos do mamoeiro (Carica Papaya). Tese de Doutorado em Biologia Vegetal - Universidade Estadual de Campinas.

Cavalier DM, Lerouxel O, Neumetzler L, Yamauchi K, Reinecke A, Freshour G, Zabotina OA, Hahn MG, Burgert I, Pauly M, et al. 2008. Disrupting two Arabidopsis thaliana xylosyltransferase genes results in plants deficient in xyloglucan, a major primary cell wall component. Plant Cell 20: 1519-1537.

Colmer TD. 2003. Long-distance transport of gases in plants: a perspective on internal aeration and radial oxygen loss from roots, Plant Cell Environ. 26: 17-36.

Cosgrove DJ. 1999. Enzymes and other agents that enhance cell wall extensibility, Annu. Rev. Plant Physiol. Plant Mol. Biol. 50: 391-417.

Cox J, Mann M. 2008. MaxQuant enables high peptide identification rates, individualized p.p.b.-range mass accuracies and proteome-wide protein quantification. Nat Biotechnol. 26: 1367-72.

Crivellari AC. 2012. Caracterização estrutural das hemiceluloses de paredes celulares de cana-de-açúcar. Dissertação entregue a Universidade de São Paulo.

Davin LB, Bedgar DL, Katayama T \& Lewis NG. 1992. On the stereospecific synthesis of pinoresinol in Forsythia suspensa from its achiral precursor, coniferyl alcohol. Phytochemistry. 31: 3869-3874.

De Souza AP, Grandis A, Leite DCC, Buckeridge MS. 2013. Sugarcane as a Bioenergy Source: History, Performance, and Perspectives for Second-Generation Bioethanol. BioEnergy Research 7: 24-35.

De Souza AP. 2011. Mecanismos fotossintéticos e relação fonte-dreno em cana-de-açúcar cultivada em atmosfera enriquecida de $\mathrm{CO}_{2}$. Tese de Doutorado pelo Instituto de Biociências da Universidade de São Paulo. 208p.

De Souza AP, Leite DCC, Pattathil S, Hahn MG, Buckeridge MS. 2013. Composition and structure of sugarcane cell wall polysaccharides: implications for second generation bioethanol. BioEnergy Research 6: 564-579.

DeFalco TA, Bender KW, Snedden WA. 2010. Breaking the code: Ca2+ sensors in plant signalling. Biochem J 425: 27-40 
Delong A, Calderon-Urrea A, Dellaporta SL. 1993. Sex determination gene TASSELSEED2 of maize encodes a short-chain alcohol dehydrogenase required for stage-specific floral organ abortion. Cell 74: 757-768.

Drew M. 1997. Oxygen deficiency and root metabolism. Annual Review of Plant Physiology and Plant Molecular Biology. 48:223-250.

Drew MC, He CJ \& Morgan PW. 1989. Decreased ethylene biosynthesis, and induction of aerenchyma, by nitrogen or phosphate starvation in adventitious roots of Zea mays L. Plant Physiol 91:266-271.

Feiz L, Irshad M, Pont-Lezica RF, Canut H \& Jamet E. 2006. Evaluation of cell wall preparations for proteomics: a new procedure for purifying cell walls from Arabidopsis hypocotyls Plant Methods. $p$ 2:10.

Drew MC, He CJ, Morgan PW. 2000.Programmed cell death and aerenchyma formation in roots. Tends in Plant Science. 5: 124-127.

Drew MC, Jackson MB, Giffard S. 1979. Ethylene-Promoted Adventitious Rooting and Development of Cortical Air Spaces (Aerenchyma) in Roots May Be Adaptive Responses to Flooding in Zea mays L. Planta 147: 83-88.

Driouich A, Laine AC, Vian B, Faye L. 1992. Characterization and localization of laccase forms in stem and cell cultures of sycamore. Plant J. 2: 13-24.

Eklof JM. 2010. Glycoside hydrolase family 16. CAZypedia. http://www. cazypedia.org (April 21, 2010)

Evans DE. 2003. Aerenchyma formation. New Phytologist, 161: 35-49.

Fagerstedt KW. 2010. Programmed Cell Death and Aerenchyma Formation Under Hypoxia. In: S. Mancuso and S. Shabala (eds.), Waterlogging Signalling and Tolerance in Plants, 99 Springer-Verlag Berlin Heidelberg.

Fan DF, Maclachlan GA. 1966. Control of cellulase activity by indoleacetic acid. Can J Bot 44: 1025-1034.

Fincher GB. 2009. Revolutionary times in our understanding of cell wall biosynthesis and remodeling in the grasses. Plant Physiol 149: 27-37

Fortes F, Castilho RF, Catisti R, Carnieri EGS, Vercesi A. 2001. Ca2+ induces a cyclosporin A- insensitive permeability transition pore in isolated potato tuber mitochondria mediated by reactive oxygen species. J Bioenerg Biomembr 33: 43-51.

Gilbert H. 2014. Developing Novel Enzyme Repertoires for the Efficient Deconstruction of Plant Biomass Tailored for the Bioenergy Industry. In: M. C. McCann et al. (eds.), Plants and BioEnergy, Advances in Plant Biology 4 p.197-209.

Gòmez LD, Whitehead C, Barakate A, Halpin C, McQueen-Mason SJ. 2010. Automated saccharification assay for determination of digestibility in plant materials. Biotechnology for Biofuels, 3-23. doi:10.1186/1754-6834-3-23.

Gòmez LM, Steele-King CG, McQueen-Mason SJ. 2008. Sustainable liquid biofuels from biomass: the writing's on the walls. New Phytologist. 178: 473-485.

Grandis A, de Souza AP, Tavares EQP, Buckeridge MS. 2014. Using Natural Plant Cell Wall Degradation Mechanisms to Improve Second Generation Bioethanol. In: M. C. McCann et al. (eds.), Plants and BioEnergy, Advances in Plant Biology 4 p.211-230. 
Gunawardena A, Lan H, Pearce DM, Jackson MB, Hawes CR \& Evans DE. 2001a. Characterization of programmed cell death during aerenchyma formation induced by ethylene or hypoxia in roots of maize (Zea mays L.). Planta 212: 205-214.

Gunawardena A, Pearce DM, Jackson MB, Hawes CR \& Evans DE. 2001b. Rapid changes in cell wall pectic polysaccharides are closely associated with early stages of Aerenchyma formation, aspatially localized form of programmed cell death in roots of maize (Zea mays L.) promoted by ethylene. Plant, Cell \& Environment 24: 1369-1375.

Harmon AC, Gribskov M, Gubrium E, Harper JF. 2001. The CDPK superfamily of protein kinases. New Phytol 151: 175-183

Hashiguchi A, Sakata K, Komatsu S. 2009. Proteome analysis of early-stage soybean seedlings under flooding stress. J. Proteome Res. 8: 2058-2069.

He CJ, Morgan PW, Drew MC. 1996a. Transduction of an ethylene signal is required for cell death and lysis in the root cortex of maize during aerenchyma formation induced by hypoxia. Plant Physiology 112: 463-472.

He CJ, Pinlayson SA, Drew MC, Jordan WR, Morgan PW. 1996b. Ethylene biosynthesis during aerenchyma formation in roots of Zea mays subjected to mechanical impedance and hypoxia. Plant Physiol 112: 1679-1685.

Hellemans J, Mortier G, De Paepe A, Speleman F, Vandesompele J. 2007. qBase relative quantification framework and software for management and automated analysis of real-time quantitative PCR data. Genome Biol. 8(2):R19.

Henry C M, Deacon JW. 1981. Natural (non-pathogenic) death of the cortex of wheat and barley seminal roots, as evidenced by nuclear staining with acridine orange. Plant and Soil 60: 255-274.

Drew MC. 1979. Properties of roots which influence rates of absorption. In: The Soil Root Interface (Ed. by J. L. Harley \& R. Scott Russell) pp. 21-38. Academic Press, London.

Hoffman M, Jia ZH, Pena MJ, Cash M, Harper A, Blackburn AR, Darvill A, York WS. 2005. Structural analysis of xyloglucans in the primary cell walls of plants in the subclass Asteridae. Carbohydr Res 340: 1826-1840.

Hoj PB, Fincher GB. 1995. Molecular evolution of plant beta-glucan endo-hydrolases, Plant J. 7: 367-379.

Horton RF, Osborne DJ. 1967. Senescence, abscission and cellulase activity in Phaseolus vulgaris. Nature 214: 1086-1088.

Hsieh YSY, Harris PJ. 2009. Xyloglucans of monocotyledons have diverse structures. Molecular Plant 2: 943-965

Iskandar HM, Simpson RS, Casu RE, Bonnett GD, Maclean DJ, Manners JM. 2004. Comparison of Reference Genes for Quantitative Real-Time Polymerase Chain Reaction Analysis of Gene Expression in Sugarcane. Plant Molecular Biology Reporter 22: 325-337.

Jackson MB, Armstrong W. 1999. Formation of aerenchyma and the processes of plant ventilation in relation to soil flooding and submergence. Plant Biology 1: 274-287.

Jackson MB, Fenning TM, Jenkins W. 1985. Aerenchyma (gas-space) formation in adventitious roots of rice (Oryza sativa L.) is not controlled by ethylene or small partial pressures of oxygen. Journal of Experimental Botany 36: 1566-1572.

Johansen DA. 1940. Plant microtechnique. Mc Graw Hill, New York. 
Justin SHFW, Armstrong W. 1991. Evidence for the involvement of ethene in aerenchyma formation in adventitious roots of rice (Oryza sativa L.). New Phytologist 118: 49-62.

Kaufmann, S.H., Hengartner, M.O., 2001. Programmed cell death: alive and well in the new millennium. Trends Cell Biol. 11: 526- 534.

Kawai M, Samarajeewa PK, Barrero RA, Nishiguchi M, Uchimiya H. 1998. Cellular dissection of the degradation pattern of cortical cell death during aerenchyma formation of rice roots. Planta 204: 277-287.

Kawase M. 1974. Aerenchyma development is often associated with a radial enlargement of cortical cells. Physiol Plant 31: 29-38.

Kawase M. 1979. Role of cellulase in aerenchyma development in sunflower. Am J Bot 66: 183-190.

Keegstra K. 2010. Plant Cell Walls. Plant Physiology, 154: 483-486.

Kim JB, Olek AT, Carpita NC. 2000. Cell wall and membrane-associated exo-beta-D-glucanases from developing maize seedlings. Plant Physiol 123: 471-86.

Komatsu S, Yamamoto R, Nanjo Y, Mikami Y, Yunokawa H, Sakata K. 2009. A comprehensive analysis of the soybean genes and proteins expressed under flooding stress using transcriptome and proteome techniques. J. Proteome Res. 8: 4766-4778.

Kong FJ, Oyanagi A, Komatsu S. 2010. Cell wall proteome of wheat roots under flooding stress using gelbased and LC MS/MS-based proteomics approaches. Biochim. Biophys. Acta 1804: 124- 136.

Konings H, Verschuren G. 1980. Formation of aerenchyma in roots of Zea mays in aerated solutions, and its relation to nutrient supply. Physiologia Plantarum 49: 265-270.

Laan P, Clement J, Blom C. 1991. Growth and development of Rumex roots as affected by hypoxic and anoxic conditions. Plant and Soil 136:145-151.

Laan P, Smolders A, Blom C, Armstrong W. 1989. The relative roles of internal aeration radial oxygen losses, iron exclusion and nutrient balance in flood tolerance of Rumex. Acta Botanica Neerlandica species. 38: 131-145.

Lam E, Kato N, Lawton M. 2001. Programed cell death, mitochondria and the plant hypersensitive response. Nature 411: 848-853.

Lashbrook CC, Gonzalez-Bosch C, Bennett AB. 1994. Two divergent endo-beta-1,4-glucanase genes exhibit overlapping expression in ripening fruit and abscising flowers, Plant Cell 6: 1485-1493.

Leite DCC. 2013. Modificações da parede celular durante a formação de aerênquima em raízes de canade-açúcar. Tese de dissertação entregue a Universidade de São Paulo.

Levy A, Erlanger M, Rosenthal M, Epel BL. 2007. A plasmodesmata-associated beta-1,3-glucanase in Arabidopsis. The plant Journal, 49: 669-682.

Lima DU, Santos, HP, Tiné MA, Molle FD, Buckeridge MS. 2001. Patterns of expression of cell wall related genes in sugar cane. Genetics and Molecular Biology 24: 191-198.

Lionetti V, Francocci F, Ferrari S, Volpi C, Bellincampi D, Galletti R, D’Ovidio R, De Lorenzo G, Cervone F. 2010. Engineering the cell wall by reducing de-methyl-esterified homogalacturonan improves saccharification of plant tissues for bioconversion. PNAS. 107: 616-621.

Laemmli UK. 1970. Cleavage of structural proteins during the assembly of the head of bacteriophage T4. Nature 227: 680-685. 
McDougall GJ, Morrison IM. 1996. Extraction and partial purification of cell wall-associated coniferyl alcohol oxidase from developing xylem of Sitka spruce. Holzforschung. 50: 549-553.

Michel G, Chantalat L, Duee E, Barbeyron T, Henrissat B, Kloareg B, Dideberg O. 2001. The kcarrageenase of $P$. carrageenovora features a tunnel-shaped active site: a novel insight in the evolution of clan-B glycoside hydrolases. Structure 9: 513-525

Mittler R, Lam E. 1995. In situ detection of nDNA fragmentation during the diferentiation of tracheary elements in higher plants. Plant Physiology 108:489-493.

Mochizuki T, Takahashi U, Shimamura S, Fukuyama M. 2000. Secondary aerenchyma formation in hypocotyl in summer leguminous crops. Jpn. J. Crop Sci. 69: 69-73.

Montes RAC, Ranocha P, Martinez Y, Minic Z, Jouanin L, Marquis M, Saulnier L, Fulton LM, Cobbett CS, Bitton F, Renou JP, Jauneau A, Goffner D. 2008. Cell Wall Modifications in Arabidopsis Plants with Altered a-L-Arabinofuranosidase Activity. Plant Physiol 147: 63-77.

Morgan PW, Drew, MC. 2004. Plant Cell Death and cell differentiation. In: Plant Cell Death Processes, Elsevier, INC. p.19-36.

Mortimer JC, Miles GP, Brown DM, Zhang Z, Segura MP, Weimar T, Yu X, Seffen KA, Stephens E, Turner SR, Dupree P. 2010. Absence of branches from xylan in Arabidopsis gux mutants reveals potential for simplification of lignocellulosic biomass. PNAS 107: 17409-14.

Nanjo Y, Skultety, L, Ashraf Y, Komatsu S. 2010. Comparative proteomic analysis of early-stage soybean seedlings responses to flooding by using gel and gel-free techniques. J. Proteome Res. 9: 39894002.

Nelson CJ, Li L, Millar AH. 2014. Quantitative analysis of protein turnover in plants. Proteomics 14: 579592.

Nishiuchi S, Yamauchi T, Takahashi H, Kotula L, Nakazono M. 2012. Mechanisms for coping with submergence and waterlogging in rice. Rice 5, 2.

Pauly M, Keegstra K. 2008. Cell-wall carbohydrates and their modification as a resource for biofuels. Plant J. 54(4):559-68.

Pennell RI, Lamb C. 1997. Programed cell death in plants. Plant Cell 9:1157-1168.

Ragauskas AJ, Williams CK, Davison BH, Britovsek G, Cairney J, Eckert CA, Frederick WJ, Hallet JP, Leak DJ, Liotta CL, et al. 2006. The path forward for biofuels and biomaterials. Science 311: 484-489.

Rahji I, Yamauchi T, Takahashi H, Nishiuchi S, Shiono K, Watanabe R, Mliki A, Nagamura Y, Tsutsumi N, Nishizawa NK, Nakazono M. 2011. Identification of genes expressed in maize root cortical cells during lysigenous aerenchyma formation using laser microdissection and microarray analyses. New Phytol 190: 351-368

Neuhoff V, Stamm R, Eibl H. et al. 1985. Clear background and highly sensitive protein staining with Coomassie Blue dyes in polyacrylamide gels: A systematic analysis. Electrophoresis 6: 427-448.

Ranocha P, Chabannes M, Chamayou S, Danoun S, Jauneau A, Boudet AM \& Goffner D. 2002. Laccase Down-Regulation Causes Alterations in Phenolic Metabolism and Cell Wall Structure in Poplar. Plant Physiol. 129: 145-155.

Reed JC. 2000. Mechanisms of apoptosis. Am J. Pathol. 157: 1415-1430. 
Rose JKC, Braam J, Fry SC, Nishitani K. 2002. The XTH family of enzymes involved in xyloglucan endotransglucosylation and endohydrolysis: current perspectives and a new unifying nomenclature. Plant Cell Physiol 43: 1421-1435.

Rose JKC, Cosgrove DJ, Albersheim P, Darvill AG \& Bennett AB. 2000. Detection of expansin proteins and activity during tomato fruit ontogeny. Plant Physiol. 123: 1583-1592.

Saab IN, Sachs MM. 1996. A flooding-induced xyloglucan endotransglycosylase homolog in maize is responsive to ethylene and associated with aerenchyma. Plant Physiol. 112: 385-391.

Sanders D, Brownlee C, Harper JF. 1999. Communication with calcium. The plant Cell. 11: 691-706.

Saraswati R, Matoh T, Sekiya J. 1992. Nitrogen fixation of Sesbania rostrata: contribution of stem nodules to nitrogen acquisition. Soil Sci. Plant Nutr. 38: 775-780.

Schussler EE, Borkhsenious ON, Longstreth DJ. 1997. Formation of root aerenchyma involves cell death in Sagittaria lancifolia. Plant Physiol 14: 456-456.

Seago JL Jr, Marsh LC, Stevens KJ, Soukup A, Votrubova O, Enstone DE. 2005. A re-examination of the root cortex in wetland flowering plants with respect to aerenchyma. Annals of Botany 96: 565-579.

Selvendran RR, O'Neil MA. 1987. Isolation and analysis of cell walls from plant material. Methods Biochem. Anal. 32:25-153.

Shevchenko A, Tomas H, Havlis J, Olsen JV, Mann M. 2006. In-gel digestion for mass spectrometric characterization of proteins and proteomes. Nature protocols 6: 2856- 2860.

Shevchenko A, Wilm M, Vorm O, Mann M. 1996. Mass spectrometric sequencing of proteins from silver stained polyacrylamide gels. Anal. Chem. 68: 850-858.

Silva AM. 2005. Caracterização da parede celular de Saccharrum officinarum L. (cana-de-açúcar) e Brachiaria decumbens Stapf (braquiária). 2005. Tese de Doutorado em Biologia Celular e Estrutural. Universidade Estadual de Campinas. 105p.

Simpson C, Thomas C, Findlay K, Bayer E, Maule AJ. 2009. An Arabidopsis GPI-anchor plasmodesmal neck protein with callose binding activity and potential to regulate cell-to-cell trafficking. The Plant Cell, 21: 581-594.

Smith J. Muldoon E. \& Lamport D. 1984. Isolation of extensin precursors by direct elution of intact tomato cell suspension cultures. Phytochemistry. 23:1233-1239.

Soccol CR, Vandenberghe LPS, Medeiros ABP, Karp SG, Buckeridge MS, Ramos LP, Pitarelo AP, FerreiraLeitão V, Gottschalk LMF, Ferrara MA. 2010. Bioethanol from lignocelluloses: Status and perspectives in Brazil. Bioresource Technology 101: 4820-4825.

Sterjiades R, Dean JFD, Eriksson KEL. 1992. Laccase from sycamore maple (Acer pseudoplatanus) polymerizes monolignols. Plant Physiol. 99: 1162-1168.

Stone BA, Clarke AE. 1992. Chemistry and biology of (1,3)-beta-glucans, La Trobe University Press, Victoria, Australia.

Subbaiah CC, Sachs MM. 2003. Molecular and cellular adaotations of maize to flooding stress. Annals of Botany. 90:119-127.

Swidzinski, JA, Leaver, CJ, Sweetlove, LJ. 2004. A proteomic analysis of plant programmed cell death. Phytochemistry 65: 1829-1838. 
Tetsushi H, Karim A. 2007. Flooding Tolerance of Sugarcane in Relation to Growth. South Pacific Studies $28, \mathrm{n} 1$.

Trewavas AJ, Malho R. 1998. Ca2+ signalling in plant cells: The big network! Curr. Opin. Plant Biol. 1: 428-433.

Trought MCT, Drew MC. 1980. The development of waterlogging damage in young wheat plants in anaerobic solution cultures. Journal of Experimental Botany 31: 1573-1580.

Vettore AL, Silva FR, Kemper EL, Arruda P. 2001. The libraries that made SUCEST. Genet. Mol. Biol. vol.24 no.1-4.

Vidal BC. 1977. Acid glycosaminoglycans and endochondral ossification: micro espectrophotometric evaluation and macromolecular orientation. Cell Molecular Biology 22: 45-64.

Virolainen E, Blokhina O, Fagerstedt KV. 2002. $\mathrm{Ca}^{2+}$ induced high amplitude swelling and cytochrome C release from wheat (Triticum aestivumL.) mitochondria under anoxic stress. Annals of Botany 90:509-516.

Visser EJW, Bögemann GM. 2006. Aerenchyma formation in the wetland plant Juncus effusus is independent of ethylene. New Phytologist 171:305-314.

Visser EJW, Voesenek LACJ, Vartapetian BB, Jackson MB. 2003. Flooding and plant growth. Annals of Botany 91: 107-109.

Walker BA, Pate JS, Kuo J. 1983. Nitrogen fixation by nodulated roots of Viminaria juncea (Schrad, \& Wendl.) Hoffmans. (Fabaceae) when submerged in water. Aust. J. Plant Physiol. 10, 409-421.

Webb J, Armstrong W. 1983. The effects of anoxia and carbohydrates on the growth and viability of rice, pea and pumpkin roots. J Exp Bot 34: 579-603.

Wingren A, Galbe M, Zacchi G. 2003. Techno-economic evaluation of producing ethanol from softwood: comparison of SSF and SHF and identification of bottlenecks. Biotechnology Progress 19: 11091117.

Worrall D, Hird DL, Hodge R, Paul W, Draper J, Scott R. 1992. Premature dissolution of the microsporocyte callose wall causes male sterility in transgenic tobacco, Plant Cell 4: 759-771.

Yukiyoshi K, Karahara I. 2014. Role of ethylene signalling in the formation of constitutive aerenchyma in primary roots of rice. AoB Plants. 24;6. pii: plu043. doi: 10.1093/aobpla/plu043.

Voigt J. 1985. Extraction by lithium chloride of hydroxyproline-rich glycoproteins from intact cells of Chlamydomonasreinhardii. Planta. 164:379-389. 
ANEXOS

Anexo 1. Oligonucleotídeos específicos das enzimas hidrolíticas de parede celular de raízes de cana de açúcar e suas respectivas especificações para a construção ( $\mathrm{Tm}$ = temperatura de melting, Esses iniciadores foram selecionados para a análise de expressão gênica por PCR em tempo real e foram sintetizados pela Invitrogen ${ }^{\circledR}$.

\begin{tabular}{|c|c|c|c|c|c|c|}
\hline $\begin{array}{l}\text { Sigla do } \\
\text { Iniciador }\end{array}$ & SAS & $\begin{array}{l}\text { Enzima } \\
\text { correspondente }\end{array}$ & Iniciador Forward & Iniciador Reverse & $\begin{array}{c}\text { Tm } \\
\text { forward }\end{array}$ & $\begin{array}{c}\mathrm{tm} \\
\text { reverse }\end{array}$ \\
\hline alfa gal1 & SCEQRT2025H02.g & alfa galactosidase & TGTACCGGCATTGCATCCTG & AACCGGCGAGGTGGTACAAA & 57.9 & 59.3 \\
\hline alfa gal2 & SCQSRT2034G08.g & alfa galactosidase & TCCCCATTCACACAGCGAGA & ACACGGACATGCAGCCAAAA & 58.6 & 58 \\
\hline alfa xil1 & SCJLRT1020A08.g & alfa xilosidase & GCTCGACGTCGTTGACCAGT & GGTGGAACCCGAAAGACCAG & 59.7 & 58.1 \\
\hline Arabin & SCQSRT1034D03.g & Arabinosidase & GGAACGCTGCTACCCTTGGA & GGCCAAGACGCGAACTGTCT & 59.7 & 60.2 \\
\hline beta xil1 & SCCCRT1002G03.g & beta xilosidase & GCCACGGCATCACAATCAGA & ACGTACCAGCCGCCTTTCAA & 58.1 & 59.5 \\
\hline beta glc1 & SCCCRT1002A11.g & beta glicosidase & СTCACTCTCCAGCCGCTGAC & TGTGCTGCTGTTGTTGCTTGA & 60.1 & 58.1 \\
\hline beta glc2 & SCCCRT1C05G04.g & beta glicosidase & ACGCCATGGGTGTTCTGACA & ACGTTGACCCTCGTTGACAGC & 59.4 & 59.9 \\
\hline beta glc3 & SCCCRT2004C04.g & beta glicosidase & GAGCGCGTCGAAGAGGTTCT & CAGCTTCTCGCAGGGCTACA & 59.6 & 59.6 \\
\hline beta glc5 & SCJLRT1020A08.g & beta glicosidase & CGACCTCCGCTACTCCATCA & CCCTTGCGAACGGGTAGAAC & 58.6 & 58.3 \\
\hline beta glc6 & SCJLRT1023E06.g & beta glicosidase & CGAAGTGCCTCTCCGTCTCA & TCGTCGACACCTTCGTCTCC & 58.9 & 58.8 \\
\hline beta $g \mid c 7$ & SCVPRT2073A02.g & beta glicosidase & СCTGCTAGCGTTGGGGAGAG & AGTCACCATGGAGGCCCAAG & 60 & 59.7 \\
\hline B13glc1 & SCCCRT2004A03.g & beta 13 glicanase & GGACGCGATCGAGAACTCCT & ACCATCGCGTCGAAGAGGTT & 59 & 58.9 \\
\hline B13glc2 & SCEQRT1026E05.g & beta 13 glicanase & GAATGCCACCGCCAGGTAGT & CAGGGGACGAGACGGAGAAG & 60 & 59.3 \\
\hline B13glc3 & SCEQRT2028C06.g & beta 13 glicanase & TGGAGTGCATCGCCGTAGTC & CCGGCTGGTTGGTAGTTGGT & 59.5 & 60 \\
\hline B13glc4 & SCJLRT1020F11.g & beta 13 glicanase & CAGGCGTACCCTTCCGTCTC & ACACCGACGTCGTCACCTTG & 59.8 & 59.8 \\
\hline B13glc5 & SCCCRT1002F03.g & beta 13 glicanase & ACCACACGTACGCCATCCTG & CGTCGTCCACGAAGAAGGTG & 59.8 & 58 \\
\hline cel1 & SCEQRT1024F11.g & Celulase & GAGTTCGCCGACAAGTACCG & GAGGAGCTCGTCGTGGTAGC & 58.1 & 59.7 \\
\hline cel2 & SCEQRT2028C06.g & Celulase & GATCAGGCTCCACGACAGCA & CTGGAGCAAGGCGTGGACTT & 59.6 & 60.2 \\
\hline cel3 & SCJLRT1023A03.g & Celulase & GCCGAAACCAACCACGTAGC & TGGTACTGCGGCCCAAACTT & 59.2 & 59.7 \\
\hline cel4 & SCJFRT1005B11.g & Celulase & GGGAGGAGCGTGTGGGTATG & GCAGCTCTGCCCATTGTTGA & 60.1 & 58.4 \\
\hline celsint1 & SCQGRT1045D11.g & celulose sintase & TCCGCCGGATTGCTGTCTAT & GGGGTGGTCCACAGGTTGAA & 58.7 & 59.8 \\
\hline celsint2 & SCQGRT1044A07.g & celulose sintase & GTCCACATGACCAGCGATGC & TCTTGGGCTGGGAGTTCGTC & 58.9 & 59.4 \\
\hline $\exp 1$ & SCJFRT2055E11.b & Expansina & GCCGCAGCCACGAGCTAATA & GGTGGCGAACCAAGTCATCC & 60.1 & 58.7 \\
\hline $\operatorname{exp2}$ & SCMCRT2107D08.g & Expansina & GCTGACGGTGACCTTCCACA & CGTCGCCGTTCTCGTACTCC & 59.8 & 60 \\
\hline $\exp 3$ & SCQSRT1034D12.g & Expansina & GCACGCCGCTCTTCAACAAT & GGAGTTTGGCGGGCAGAAAT & 59 & 58.5 \\
\hline exp4 & SCQSRT1036C01.g & Expansina & GTTGGCGTACTCCACCAGCA & CGGGGGCTCACTGTCAACTT & 60.1 & 59.9 \\
\hline $\operatorname{exp5}$ & SCVPRT2075H10.g & Expansina & CCGGGGAGGCAGTACTTGAG & GATCTGGGGAAGCACGGCTA & 59.8 & 59.3 \\
\hline exp6 & SCRURT2011A12.g & Expansina & CTGCGGCCAGTGCTACAAGA & AAGTTGGTGGCGGTGATGGT & 60.1 & 59.7 \\
\hline $\exp 7$ & SCVPRT2077B02.g & Expansina & CAGCGTCCCTTCTCGTCGAT & CACATCCCTTGCCTCCCTTG & 59.2 & 58.3 \\
\hline Fucosil & SCEQRT1031G07.g & Fucosiltransferase & СCTCCTTCTGCGGGAACATC & TCTTCTGCGACGAGGACCAG & 57.9 & 58.9 \\
\hline Bgal1 & SCCCRT1002C07.g & Betagalactosidase & CGTTCATCGCCACCAGCTAC & TCCCTCAGGTGACCCCATTT & 58.5 & 58.4 \\
\hline Bgal2 & SCEPRT2044F09.g & Betagalactosidase & CGGCCCTCGAAGTCGTACTG & CCGGCTCCATCCACTATCCA & 59.9 & 58.9 \\
\hline gal1 & SCEQRT2025H02.g & Galactosidase & GGCGTCATATGCTGGACCTG & GGTCATGCCACCATTGCCTA & 58.2 & 57.8 \\
\hline gal2 & SCQSRT2034G08.g & Galactosidase & ATGAGTGCGCCCATAGGTCA & GGCCACTCAGCAACAACAGG & 58.8 & 59.1 \\
\hline
\end{tabular}




\section{Continuação Anexo 1.}

\begin{tabular}{|c|c|c|c|c|c|c|}
\hline $\begin{array}{l}\text { número } \\
\text { Iniciador }\end{array}$ & SAS & Enzima & Iniciador Forward & Inicicador Reverse & $\begin{array}{c}\mathrm{Tm} \\
\text { forward }\end{array}$ & $\begin{array}{c}\text { tm } \\
\text { reverse }\end{array}$ \\
\hline lich1 & SCCCRT2004C04.g & Lichenase & CGCGTCGAAGAGGTTCTGGT & TCAGCTACGCGCTCTTCACG & 59.6 & 59.8 \\
\hline lich2 & SCEQRT1026E05.g & Lichenase & TGGCTGGGAGGATCTTCTGC & AACCTGGACGCGCTCATCTC & 59.4 & 59.8 \\
\hline lich3 & SCJLRT1023E06.g & Lichenase & AGCGCGTCGAAGAGGTTCTG & CCGCTGCTCTGCAACGTCTA & 59.8 & 59.9 \\
\hline lich4 & SCJLRT1020F11.g & Lichenase & CCGTCTCCTTCCGCTACGTG & CCGACGTCGTCACCTTGATG & 59.9 & 58.1 \\
\hline Man & SCJLRT1020C03.g & Mananases & AATTCCGCCTCAGGAGTGGAC & AATTCCGCCTCAGGAGTGGAC & 59.3 & 59.7 \\
\hline pec ac 1 & SCQGAM1045B09.g & pectina acetil esterase & TCCCCCAGAACGAGGTGAAA & CTCCTGGCACCAAAATGTTCCTT & 58.4 & 58 \\
\hline pec ac2 & SCJLFL3013D11.g & pectina acetil esterase & CCGTATCCCTGCAACCCAACT & GGCGAGGTGTGATCCCTCATT & 59.6 & 59.4 \\
\hline pec1 & SCAGRT2038D08.g & pectina methyl esterase & GCACCAAGCTCCTCCCTGAA & GCCGGGTTACCACTTCCAGA & 59.8 & 59.4 \\
\hline pec2 & SCJFRZ2027H04.g & pectina methyl esterase & GCGTTCAAGTGGCACCTCAG & CCGTCGAGGCAGGTGTTCT & 59 & 59.7 \\
\hline pec3 & SCQSLB1052E07.g & pectina methyl esterase & AACGCGCTCTCCCTCTACGA & ACGAACGAGAACCCCGTGTC & 60.5 & 59.6 \\
\hline poli1 & SCEZRT2016H09.g & Poligalacturonase & CAGCAACGATGTGCAGGTCA & CGTCCCGGACTCGATGGATA & 58.3 & 58.3 \\
\hline poli2 & SCEPFL3083G08.g & Poligalacturonase & GTTGCCGGTCATCCAGAACA & GCGGCTTTGTCAGGGACATT & 57.8 & 58.4 \\
\hline xth1 & SCEQRT3C03E06.g & XTH & GACCCCACCAAGGACTTCCA & CTGATCGGCATCTCGTCCAC & 59.3 & 57.8 \\
\hline xth2 & SCEQRT2101A02.g & XTH & CAACTCCACGCGCAAGTACC & GACGTCAGGTAGAAGGAGGTGACA & 58.9 & 59.7 \\
\hline xth3 & SCQSRT2034B07.g & XTH & CTTCTACCTGTCGTCGCAGAACTC & GTCCGGTTGCCCAGGAACT & 58.9 & 60.2 \\
\hline Feruloil & SCCCLB1004H01.g & feruloil esterase & CCGGGGCTACTACGGGAAC & GAGGACGGAAAGCCCATCAG & 60 & 57.9 \\
\hline lac1 & SCACSB1039F01.g & Lacase & TGGCCATGGCAATCTCCTCT & CGTGTCACGTTCGCCATTGT & 59.9 & 58.5 \\
\hline lac2 & SCACSB1123H10.g & Lacase & CGGCTGCTCCTTCTCCTCTC & СCTCTTCACCGGCGTCTCTT & 59.7 & 59.3 \\
\hline lac3 & SCCCSD1090D07.g & Lacase & GGTGGAATGCAGACGTGGAG & GGCTGGCCGTTAATGGTGTT & 58.3 & 58.5 \\
\hline Ilaxyl & SCJLRT1020A08.g & Alfa xilosidase & GAGCTCTGCAGTCGCTGGAT & CACCAGCTCCCACAGGTACA & 59.6 & 59.2 \\
\hline II man & SCJLRT1020C03.g & Mananase & ACAACAGGCAAGGCCCCTAA & TGGTGGTGCAGAAGCTTGAAA & 59.4 & 57.4 \\
\hline Ilbglu13a & SCEQRT1026E05.g & Beta glicosidase & GACTCCСССTCССТCTCCAT & GCAGAGCTCGACGACAGTGAA & 60.4 & 59.3 \\
\hline Ilb13gluB & SCEQRT2028C06.g & Beta glicosidase & ATGGTGCGCTGCCAGATTTA & GCTTCGCCTTCTCCATTCCA & 57,4 & 57.7 \\
\hline Ilb13gluC & SCJLRT1020F11.g & Beta glicosidase & СTCCTCGGGGTCTTTGCATC & TGCCGTTCGACTTGTGCAT & 57.9 & 57.7 \\
\hline Ilxet & SCBGLR1023F11.g & XTH & CGCTGCACAAGAGAGGAGGA & GCCACCACCACCACCATTC & 59.3 & 59.2 \\
\hline Ilcel & SCUTFL1057D12.g & Celulase & GTAGGCGAGCGAGGAGAGGA & AGGACGAAGGCGACGAAGAG & 60.6 & 59.1 \\
\hline
\end{tabular}


Anexo 2. Total de proteínas (1082) encontradas nas raízes de cana. Numeros de peptídeos e de proteínas bem como o peso molecular e o tamanho das sequencias encontradas a partir da busca no banco de dados do Sucest. Montagem realizada pelo software Maxquant.

\begin{tabular}{|c|c|c|c|c|c|c|c|}
\hline & Sucest & nome proteina & espécie & $\mathrm{N}$ proteinas & Peptideos & Peso mol. & $\begin{array}{l}\text { Tamanho } \\
\text { sequencia }\end{array}$ \\
\hline 1 & SCRLLB2031B03.g & \begin{tabular}{|l} 
(3R)-hydroxymyristoyl-[acyl carrier protein] dehydratase \\
\end{tabular} & & 4 & 1 & 15.2 & 165 \\
\hline 2 & SCJFRT1058F10.g & (P41345) Ferredoxin-NADP reductase, root isozyme & & 6 & 4 & 15.486 & 148 \\
\hline 3 & SCCCLR1C05H04.g & (Q00351) Xyl3 precursor & & 4 & 6 & 34.528 & 319 \\
\hline 4 & SCCCRT1002B11.g & (Q40007) Putative $32.7 \mathrm{kDa}$ jasmonate-induced protein & & 1 & 4 & 59.853 & 517 \\
\hline 5 & SCRFLR1012E03.g & (Q42553) Isopentenyl-diphosphate delta-isomerase II & & 1 & 2 & 45.249 & 408 \\
\hline 6 & SCCCRZ2001A01.g & $10 \mathrm{kDa}$ chaperonin OS & Arabidopsis thaliana & 1 & 2 & 11.932 & 108 \\
\hline 7 & SCMCLR1125D12.g & $116 \mathrm{kDa}$ U5 small nuclear ribonucleoprotein component & Gallus gallus & 2 & 2 & 46.615 & 434 \\
\hline 8 & SCRLAM1013H08.g & Elongation factor Tu GTP-binding domain protein 2 & & 2 & 4 & 12.793 & 115 \\
\hline 9 & SCEPAM2055H02.g & 13S globulin seed storage protein 1 OS & Fagopyrum esculentum & 1 & 3 & 39.045 & 353 \\
\hline 10 & SCEQRT1028B06.g & $14 \mathrm{kDa}$ proline-rich protein DC2.15 OS & Daucus carota & 2 & 4 & 27.926 & 248 \\
\hline 11 & SCCCCL4011G09.g & 14-3-3 protein & & 1 & 2 & 23.346 & 213 \\
\hline 12 & SCCCLR1022D05.g & 14-3-3-like protein GF14-6 OS & Zea mays & 3 & 3 & 15.676 & 142 \\
\hline 13 & SCRUFL1017E10.b & 14-3-3-like protein GF14-6 OS & Zea mays & 3 & 13 & 36.235 & 334 \\
\hline 14 & SCCCRZ1001D02.g & 14-3-3-like protein GF14-C OS & Oryza sativa subsp. japonica & 1 & 5 & 23.82 & 219 \\
\hline 15 & SCCCLR1048F12.g & 14-3-3-like protein GF14-D OS & Oryza sativa subsp. japonica & 4 & 5 & 17.704 & 166 \\
\hline 16 & SCCCLR1C01F03.g & $14.5 \mathrm{kDa}$ translational inhibitor protein (p14.5) & & 1 & 2 & 24.994 & 222 \\
\hline 17 & SCCCCL3001G11.b & 2-dehydro-3-deoxyphosphooctonate aldolase & & 6 & 5 & 11.991 & 104 \\
\hline 18 & SCCCLR1065G03.g & $26 \mathrm{~S}$ protease regulatory subunit $7 \mathrm{OS}$ & Oryza sativa subsp. japonica & 6 & 1 & 16.582 & 150 \\
\hline 19 & SCCCCL4006C07.g & $26 \mathrm{~S}$ protease regulatory subunit 8 homolog $\mathrm{A} O \mathrm{OS}$ & Arabidopsis thaliana & 1 & 5 & 19.32 & 174 \\
\hline 20 & SCEQRT1025A07.g & 26S proteasome non-ATPase regulatory subunit 1 OS & Mus musculus GN & 1 & 2 & 20.429 & 199 \\
\hline 21 & SCCCRZ1004C09.g & 26S proteasome non-ATPase regulatory subunit 13 & & 1 & 1 & 9.3192 & 88 \\
\hline 22 & SCCCLR1048F08.g & $26 \mathrm{~S}$ proteasome non-ATPase regulatory subunit 14 & Zea mays & 1 & 3 & 26.317 & 251 \\
\hline 23 & SCEZRZ1015F05.g & 26S proteasome non-ATPase regulatory subunit 2 OS & Rattus norvegicus GN & 1 & 7 & 30.035 & 279 \\
\hline 24 & SCCCLR1072B10.g & 26S proteasome non-ATPase regulatory subunit 6 & & 1 & 2 & 19.858 & 180 \\
\hline 25 & SCCCLR1065E09.g & 3-dehydroquinate synthase OS & & 1 & 1 & 16.793 & 169 \\
\hline 26 & SCCCCL3080E11.g & 3-hydroxyisobutyryl-CoA hydrolase-like protein 3 OS & Arabidopsis thaliana & 1 & 3 & 27.583 & 254 \\
\hline 27 & SCSGLR1045F04.g & 3-isopropylmalate dehydrogenase & & 3 & 3 & 18.583 & 166 \\
\hline 28 & SCEQLR1007G01.g & 3-N-debenzoyl-2-deoxytaxol N-benzoyltransferase OS & Taxus canadensis & 3 & 1 & 12.487 & 122 \\
\hline 29 & SCJFRZ1005C03.g & 3-N-debenzoyl-2-deoxytaxol N-benzoyltransferase OS & Taxus canadensis & 18 & 5 & 15.268 & 136 \\
\hline 30 & SCRLAD1101G08.g & 4-coumarate-CoA ligase & & 1 & 3 & 38.516 & 363 \\
\hline 31 & SCACLR1126F04.g & $40 \mathrm{~S}$ ribosomal protein S10 OS & Oryza sativa subsp. japonica & 24 & 12 & 11.409 & 103 \\
\hline 32 & SCCCLR2C01F11.g & 40S ribosomal protein S10 OS & Oryza sativa subsp. japonica & 2 & 1 & 21.989 & 204 \\
\hline 33 & SCAGLR1021C06.g & $40 \mathrm{~S}$ ribosomal protein S11 & & 2 & 2 & 34.56 & 306 \\
\hline 34 & SCCCLR1C01C07.g & $40 \mathrm{~S}$ ribosomal protein $\mathrm{S} 12$ & & 1 & 8 & 63.751 & 582 \\
\hline 35 & SCCCLR1024D10.g & $40 \mathrm{~S}$ ribosomal protein $\mathrm{S} 13$ & & 1 & 3 & 21.315 & 194 \\
\hline 36 & SCCCLR1C03A02.g & $40 \mathrm{~S}$ ribosomal protein S14 OS & Zea mays & 2 & 28 & 41.434 & 364 \\
\hline 37 & SCCCLR2C02A08.g & $40 \mathrm{~S}$ ribosomal protein S15 & & 2 & 2 & 45.146 & 404 \\
\hline 38 & SCCCRZ2C01G03.g & 40 S ribosomal protein S15a-1 OS & Arabidopsis thaliana & 5 & 6 & 17.69 & 159 \\
\hline 39 & SCCCLR2002A05.g & $40 \mathrm{~S}$ ribosomal protein S16 & & 1 & 10 & 46.311 & 419 \\
\hline 40 & SCCCRZ2002C12.g & 40S ribosomal protein S18 OS & Arabidopsis thaliana & 2 & 11 & 36.979 & 337 \\
\hline 41 & SCCCLR1001H01.g & $40 \mathrm{~S}$ ribosomal protein $\mathrm{S} 18$ & & 1 & 2 & 65.428 & 587 \\
\hline 42 & SCVPLB1020B05.g & 40S ribosomal protein S19 OS & Oryza sativa subsp. japonica & 1 & 7 & 29.259 & 274 \\
\hline 43 & SCCCLR2001F07.g & $40 \mathrm{~S}$ ribosomal protein S20 OS & Oryza sativa subsp. japonica & 4 & 17 & 68.464 & 621 \\
\hline 44 & SCCCCL3080D07.g & $40 \mathrm{~S}$ ribosomal protein $\mathrm{S} 20$ & & 2 & 11 & 55.669 & 503 \\
\hline 45 & SCACLR2007B02.g & $40 \mathrm{~S}$ ribosomal protein S23 (S12) & & 2 & 30 & 102.2 & 906 \\
\hline 46 & SCAGLR2018G06.g & $40 \mathrm{~S}$ ribosomal protein S24-1 OS & Arabidopsis thaliana & 1 & 1 & 18.366 & 175 \\
\hline 47 & SCJLLR1054C12.g & 40 S ribosomal protein S24-1 OS & Arabidopsis thaliana & 1 & 5 & 26.48 & 245 \\
\hline 48 & SCCCLR2C02E06.g & 40 S ribosomal protein S26 OS & Oryza sativa subsp. japonica & 1 & 4 & 79.857 & 717 \\
\hline 49 & SCCCLR1C07D10.g & $40 \mathrm{~S}$ ribosomal protein S28 OS & Zea mays & 1 & 4 & 51.497 & 493 \\
\hline 50 & SCCCCL3001F09.g & $40 \mathrm{~S}$ ribosomal protein S3-3 OS & Arabidopsis thaliana & 2 & 8 & 33.047 & 299 \\
\hline 51 & SCBGLR1047A12.g & $40 \mathrm{~S}$ ribosomal protein S3a OS & Oryza sativa subsp. japonica & 1 & 3 & 24.173 & 222 \\
\hline 52 & SCCCCL3080E05.g & $40 \mathrm{~S}$ ribosomal protein $\mathrm{S} 4$ & & 7 & 7 & 16.832 & 149 \\
\hline 53 & SCVPRZ2036B07.g & 40S ribosomal protein $\mathrm{S4}$ & & 1 & 2 & 16.767 & 150 \\
\hline 54 & SCEZLB1009E10.g & $40 \mathrm{~S}$ ribosomal protein $\mathrm{S} 6 \mathrm{OS}$ & Asparagus officinalis & 1 & 2 & 23.566 & 203 \\
\hline 55 & SCCCRZ2002D10.g & $40 \mathrm{~S}$ ribosomal protein $\mathrm{S} 8$ & & 10 & 6 & 20.554 & 180 \\
\hline 56 & SCSGLR1045A06.g & 40S ribosomal protein SA (p40) & & 3 & 6 & 32.379 & 298 \\
\hline 57 & SCCCST1001H07.g & 40S ribosomal protein SA OS & Vitis vinifera & 3 & 1 & 15.915 & 141 \\
\hline 58 & SCAGLR1064H08.g & $41 \mathrm{kDa}$ chloroplast nucleoid DNA binding protein (CND41) & & 1 & 11 & 49.394 & 435 \\
\hline 59 & SCCCRZ2C03A09.g & 5-methyltetrahydropteroyltriglutamate--homocysteine & Catharanthus roseus & 2 & 3 & 41.938 & 386 \\
\hline 60 & SCCCCL4015F02.g & Vitamin-B12-independent methionine synthase isozyme & & 4 & 8 & 23.863 & 208 \\
\hline 61 & SCCCCL3140E08.g & 5-phosphoribosyl-5-aminoimidazole synthetase & & 2 & 2 & 18.511 & 178 \\
\hline 62 & SCCCRT1003G09.g & 6-phosphofructokinase & & 2 & 4 & 20.29 & 184 \\
\hline 63 & SCQSLR1040E09.g & 6-phosphogluconate dehydrogenase, decarboxylating OS & Synechococcus elongatus & 1 & 4 & 50.516 & 463 \\
\hline 64 & SCJFRZ1005F06.g & 6,7-dimethyl-8-ribityllumazine synthase (DMRL synthase) & & 1 & 1 & 19.91 & 189 \\
\hline 65 & SCACLR1036B11.g & 60S acidic ribosomal protein $\mathrm{PO} O \mathrm{OS}$ & Zea mays & 1 & 1 & 15.488 & 147 \\
\hline 66 & SCCCHR1003C05.g & 60S acidic ribosomal protein P2A OS & Zea mays & 1 & 2 & 55.37 & 517 \\
\hline 67 & SCEQSD2074C06.g & 60S acidic ribosomal protein P3 OS & Zea mays & 1 & 4 & 17.373 & 157 \\
\hline 68 & SCEPRZ1010E07.g & 60S ribosomal protein L10-1 OS & Oryza sativa subsp. japonica & 1 & 1 & 19.833 & 189 \\
\hline 69 & SCCCLR1C05G05.g & 60S ribosomal protein L10a-1 OS & Arabidopsis thaliana & 2 & 5 & 10.77 & 98 \\
\hline 70 & SCSGLR1045F12.g & 60S ribosomal protein L11 60S ribosomal protein L11 & & 1 & 11 & 50.563 & 447 \\
\hline 71 & SCCCLR1C01C09.g & 60S ribosomal protein L12-1 & & 1 & 10 & 56.205 & 518 \\
\hline 72 & SCCCCL3003G05.b & 60S ribosomal protein L13-2 (Cold-induced protein C24B) & & 1 & 13 & 28.968 & 256 \\
\hline 73 & SCRFLR1012C07.g & 60S ribosomal protein L13a-4 & & 3 & 8 & 43.013 & 384 \\
\hline 74 & SCBGLR1120F10.g & 60S ribosomal protein L17 OS & Zea mays & 1 & 3 & 107.52 & 967 \\
\hline 75 & SCBFLR1046F11.g & 60S ribosomal protein L18-3 OS & Arabidopsis thaliana & 4 & 3 & 17.253 & 151 \\
\hline 76 & SCJFLR1013D01.g & 60S ribosomal protein L18a & & 2 & 2 & 36.136 & 331 \\
\hline 77 & SCQGLR2025D05.g & 60S ribosomal protein L18a & & 2 & 4 & 21.254 & 188 \\
\hline 78 & SCUTLR1058F06.g & 60S ribosomal protein L18a & & 1 & 2 & 61.964 & 546 \\
\hline 79 & SCVPLB1019D09.g & 60S ribosomal protein L19-1 (Protein EMBRYO DEFECTIVE & & 1 & 7 & 55.66 & 500 \\
\hline 80 & SCVPLR2027H04.g & 60S ribosomal protein L2 (L8) (Ribosomal protein TL2) & & 1 & 3 & 19.423 & 175 \\
\hline 81 & SCCCLR1C02E07.g & 60S ribosomal protein $\mathrm{L} 22-2$ & & 1 & 1 & 33.135 & 324 \\
\hline 82 & SCUTLR1037D09.g & $60 \mathrm{~S}$ ribosomal protein $\mathrm{L} 24 \mathrm{OS}$ & Hordeum vulgare & 2 & 2 & 13.375 & 122 \\
\hline
\end{tabular}


Continuaçao Anexo 2.

\begin{tabular}{|c|c|c|c|c|c|c|c|}
\hline 83 & SCCCLR2C01D05.g & 60S ribosomal protein L26-1 & & 1 & 9 & 48.891 & 427 \\
\hline 84 & SCBGLR1023G09.g & $60 \mathrm{~S}$ ribosomal protein $\mathrm{L} 27-3 \mathrm{OS}$ & Arabidopsis thaliana & 2 & 1 & 41.925 & 381 \\
\hline 85 & SCCCLR1C05C08.g & 60S ribosomal protein L27-3 OS & Arabidopsis thaliana & 5 & 3 & 20.648 & 194 \\
\hline 86 & SCCCLR2003G02.g & $60 \mathrm{~S}$ ribosomal protein $\mathrm{L} 3$ & & 3 & 4 & 25.262 & 224 \\
\hline 87 & SCUTLR2023C08.g & $60 \mathrm{~S}$ ribosomal protein $\mathrm{L} 30 \mathrm{OS}$ & Zea mays & 2 & 7 & 67.393 & 611 \\
\hline 88 & SCAGLR2033B10.g & $60 S$ ribosomal protein L31 & & 2 & 8 & 41.154 & 386 \\
\hline 89 & SCCCLR1C07F11.g & 60S ribosomal protein L32-1 & & 1 & 2 & 60.127 & 547 \\
\hline 90 & SCCCRZ2004F07.g & 60S ribosomal protein L34 OS & Nicotiana tabacum & 1 & 1 & 32.082 & 291 \\
\hline 91 & SCCCRZ2C01A11.g & $60 S$ ribosomal protein L34 & & 1 & 1 & 20.489 & 197 \\
\hline 92 & SCBFLR1039F03.g & 60S ribosomal protein L35a-3 OS & Arabidopsis thaliana & 4 & 2 & 10.737 & 93 \\
\hline 93 & SCCCRZ2002C01.g & 60S ribosomal protein $\mathrm{L} 37 \mathrm{a}$ & & 1 & 1 & 14.54 & 131 \\
\hline 94 & SCCCLR2C02C11.g & 60S ribosomal protein $\mathrm{L} 38$ & & 2 & 2 & 13.579 & 127 \\
\hline 95 & SCCCRZ1001C08.g & 60S ribosomal protein L4-1 (L1) & & 3 & 2 & 9.6229 & 86 \\
\hline 96 & SCEQLR1091D05.g & 60S ribosomal protein L5-1 OS & Oryza sativa subsp. japonica & 1 & 2 & 20.207 & 181 \\
\hline 97 & SCUTLR1037F12.g & 60 ribosomal protein L5-1 OS & Oryza sativa subsp. japonica & 1 & 2 & 35.924 & 321 \\
\hline 98 & SCCCLR1048A09.g & $60 \mathrm{~S}$ ribosomal protein $\mathrm{L} 5$ & & 1 & 2 & 17.093 & 158 \\
\hline 99 & SCCCCL3080C04.g & 60S ribosomal protein L6-3 & & 3 & 4 & 24.77 & 219 \\
\hline 100 & SCEQLB1063E01.g & 60S ribosomal protein L6-3 & & 1 & 1 & 34.39 & 314 \\
\hline 101 & SCCCLR2004C07.g & 60 s ribosomal protein L7-4 OS & Arabidopsis thaliana & 17 & 5 & 15.406 & 136 \\
\hline 102 & SCCCRZ2001H04.g & 60 r ribosomal protein L7A & & 2 & 3 & 20.62 & 195 \\
\hline 103 & SCVPLR1028C12.g & $60 S$ ribosomal protein L7A & & 3 & 1 & 20.581 & 182 \\
\hline 104 & SCCCLR1069A12.g & 60S ribosomal protein L9 OS & Oryza sativa subsp. japonica & 3 & 3 & 25.583 & 250 \\
\hline 105 & SCVPCL6046C02.g & $A B C$ transporter & & 1 & 3 & 23.999 & 226 \\
\hline 106 & SCRFLR1012H05.g & Actin-1 OS & Oryza sativa subsp. japonica & 3 & 5 & 37.08 & 339 \\
\hline 107 & SCEZLR1009B09.g & Actin-1 & & 1 & 1 & 13.573 & 131 \\
\hline 108 & SCQSLR1018C05.g & Actin-2 Actin-2 & & 1 & 3 & 108.84 & 963 \\
\hline 109 & SCCCRZ1001E09.g & Actin-7 OS & Arabidopsis thaliana & 3 & 7 & 44.222 & 407 \\
\hline 110 & SCCCLR1069D05.g & Actin-7 & & 2 & 5 & 25.885 & 240 \\
\hline 111 & SCBGLR1095G03.g & Actin-depolymerizing factor 3 OS & Zea mays & 3 & 2 & 20.06 & 179 \\
\hline 112 & SCACLR1057G08.g & Activator of $90 \mathrm{kDa}$ heat shock protein ATPase homolog 1 & & 1 & 3 & 42.633 & 381 \\
\hline 113 & SCQGRZ3013E03.g & Acyl-[acyl-carrier-protein] desaturase, chloroplastic OS & Oryza sativa subsp. japonica & 2 & 3 & 20.505 & 196 \\
\hline 114 & SCAGRT2037F12.g & Acyl-CoA-binding protein OS & Ricinus communis & 1 & 2 & 66.597 & 605 \\
\hline 115 & SCEQRT1031B11.g & Acyl-coenzyme $A$ oxidase 3 , peroxisomal OS & Arabidopsis thaliana & 1 & 6 & 17.52 & 156 \\
\hline 116 & SCACLR1057G05.g & Acyl-coenzyme A oxidase 4, peroxisomal OS & Arabidopsis thaliana & 1 & 3 & 69.168 & 631 \\
\hline 117 & SCCCLB1004H08.g & Adenosine kinase 2 OS & Arabidopsis thaliana & 4 & 4 & 33.719 & 298 \\
\hline 118 & SCCCLR1C04E01.g & Adenosylhomocysteinase & & 1 & 4 & 26.377 & 238 \\
\hline 119 & SCCCLR1024H08.g & Adenylate kinase B OS & Oryza sativa subsp. japonica & 2 & 2 & 19.71 & 176 \\
\hline 120 & SCCCCL4007F09.g & adenylosuccinate lyase & & 4 & 2 & 16.91 & 149 \\
\hline 121 & SCCCLR1024H05.g & ADP,ATP carrier protein 2, mitochondrial OS & Zea mays & 1 & 6 & 23.18 & 211 \\
\hline 122 & SCQGLR1019A07.g & ADP,ATP carrier protein 2, mitochondrial OS & Zea mays & 3 & 6 & 14.28 & 133 \\
\hline 123 & SCJFFL3C06D10.b & Agmatine deiminase OS & Arabidopsis thaliana & 2 & 4 & 22.966 & 211 \\
\hline 124 & SCCCRT1002C05.g & Alanine aminotransferase $2 \mathrm{OS}$ & Panicum miliaceum & 1 & 1 & 24.89 & 240 \\
\hline 125 & SCCCLR1024G01.g & Alanyl-tRNA synthetase & & 1 & 3 & 42.057 & 408 \\
\hline 126 & SCEPRZ1008B12.g & Alba-like protein C9orf23 homolog & & 4 & 2 & 26.825 & 237 \\
\hline 127 & SCCCRZ2001F10.g & Aldehyde dehydrogenase family 2 member B7 & Arabidopsis thaliana & 1 & 3 & 23.211 & 226 \\
\hline 128 & SCRUAD1134G06.g & Aldose 1-epimerase; Galactose mutarotase; Type-1 & & 1 & 1 & 24.992 & 248 \\
\hline 129 & SCCCLR2004B02.g & Aldose reductase OS & Hordeum vulgare & 1 & 1 & 8.6121 & 79 \\
\hline 130 & SCRLLR1038C12.g & Allene oxide cyclase 3 , chloroplastic OS & Arabidopsis thaliana & 1 & 2 & 26.132 & 251 \\
\hline 131 & SCAGLR1043E04.g & Allene oxide synthase 2 OS & Oryza sativa subsp. japonica & 2 & 4 & 22.504 & 206 \\
\hline 132 & SCCCCL6004H11.g & Alpha-amylase type A isozyme OS & Hordeum vulgare & 1 & 1 & 26.566 & 230 \\
\hline 133 & SCEQRT2025H02.g & Alpha-galactosidase & & 1 & 3 & 20.589 & 205 \\
\hline 134 & SCQSRT2034G08.g & Alpha-galactosidase & & 1 & 5 & 18.056 & 173 \\
\hline 135 & SCUTLR1037C07.g & Alpha-galactosidase & & 2 & 3 & 38.318 & 346 \\
\hline 136 & SCQSRT1034D03.g & Alpha-L-arabinofuranosidase & & 1 & 3 & 59.313 & 516 \\
\hline 137 & SCACLR1036F01.g & Alpha-L-fucosidase 2 OS & Arabidopsis thaliana & 1 & 1 & 23.795 & 226 \\
\hline 138 & SCBFLR1083E01.g & Alpha-mannosidase (GH family 38) & & 1 & 6 & 77.596 & 723 \\
\hline 139 & SCBGLR1003C11.g & Alpha-mannosidase (GH family 38) & & 1 & 3 & 23.024 & 216 \\
\hline 140 & SCJFRZ3C01G05.g & Alpha-mannosidase (GH family 38) & & 1 & 3 & 92.321 & 887 \\
\hline 141 & SCJLRT1020C03.g & Alpha-mannosidase (GH family 38) & & 1 & 9 & 50.996 & 467 \\
\hline 142 & SCMCCL6051E03.g & Alpha-mannosidase (GH family 38) & & 1 & 4 & 104.56 & 962 \\
\hline 143 & SCCCRZ2002F09.g & Alpha-soluble NSF attachment protein OS & Solanum tuberosum & 4 & 5 & 45.72 & 427 \\
\hline 144 & SCRFFL5039E01.g & Alpha-xylosidase OS & Arabidopsis thaliana & 2 & 5 & 32.855 & 302 \\
\hline 145 & SCCCRZ1003D03.g & Aminoacylase-1 (N-acyl-L-amino-acid amidohydrolase) & & 2 & 3 & 36.806 & 337 \\
\hline 146 & SCQGLR2032D01.g & Aminoacylase-1 ( $\mathrm{N}$-acyl-L-amino-acid amidohydrolase) & & 5 & 15 & 120.63 & 1110 \\
\hline 147 & SCCCRZ2003A07.g & Aminopeptidase M & & 1 & 4 & 64.22 & 558 \\
\hline 148 & SCJFRT2059E04.g & Aminopeptidase M & & 2 & 10 & 103.87 & 948 \\
\hline 149 & SCJLLR1054G06.g & Aminopeptidase N; Alpha-aminoacylpeptide hydrolase & & 3 & 16 & 65.994 & 598 \\
\hline 150 & SCCCRT1002H01.g & Aminosugars metabolism & & 2 & 3 & 64.121 & 585 \\
\hline 151 & SCEZLB1008B10.g & Aminosugars metabolism & & 8 & 9 & 96.119 & 873 \\
\hline 152 & SCEZLB1009H05.g & Aminosugars metabolism & & 7 & 14 & 49.687 & 451 \\
\hline 153 & SCJFRZ2015D10.g & Aminosugars metabolism & & 1 & 4 & 16.866 & 177 \\
\hline 154 & SCCCRZ1C02F12.g & Annexin & & 3 & 5 & 75.297 & 689 \\
\hline 155 & SCCCRZ2004A11.g & Annexin & & 3 & 7 & 27.666 & 245 \\
\hline 156 & SCSBST3098G08.g & Annexin & & 2 & 4 & 67.457 & 633 \\
\hline 157 & SCEQLR1007C02.g & AP-1 complex subunit beta-1; & & 1 & 1 & 55.257 & 499 \\
\hline 158 & SCAGLR1043B02.g & AP-2 complex subunit mu; Mu2-adaptin; & & 7 & 8 & 32.635 & 291 \\
\hline 159 & SCAGLR2033E03.g & aquaporin & Saccharum officinarum & 4 & 32 & 111.32 & 980 \\
\hline 160 & SCQGLR1041H04.g & Aquaporin PIP2-1 OS & Zea mays & 1 & 7 & 42.167 & 388 \\
\hline 161 & SCCCLR1024C03.g & Aquaporin TIP1-1 OS & Zea mays & 3 & 3 & 21.183 & 191 \\
\hline 162 & SCJFRT1010C08.g & Aquaporin TIP2-1 (Tonoplast intrinsic protein 2-1) & & 1 & 11 & 23.729 & 217 \\
\hline 163 & SCBGRT1052E01.g & Aquaporin TIP2-3; Tonoplast intrinsic protein 2-3; & & 2 & 4 & 29.424 & 276 \\
\hline 164 & SCEPCL6023H11.g & ARC (armadillo/beta-catenin repeat family protein) & & 1 & 3 & 85.202 & 782 \\
\hline 165 & SCEPRZ1009G01.g & Arf & & 5 & 3 & 30.587 & 279 \\
\hline 166 & SCCCCL3004C10.b & Aspartate aminotransferase; AspAT; Transaminase A & & 1 & 7 & 38.487 & 372 \\
\hline 167 & SCRLRZ3042B09.g & Aspartic proteinase nepenthesin-1 OS & Nepenthes gracilis & 1 & 5 & 39.626 & 372 \\
\hline
\end{tabular}


Continuaçao Anexo 2.

\begin{tabular}{|c|c|c|c|c|c|c|c|}
\hline 168 & SCBGLR1120C11.g & Aspartic proteinase nepenthesin-1; Nepenthesin-l; & & 3 & 2 & 22.206 & 200 \\
\hline 169 & SCQGSB1083B11.g & Aspartic proteinase nepenthesin-1; Nepenthesin-I; & & 1 & 1 & 66.291 & 595 \\
\hline 170 & SCVPRZ2038B09.g & Aspartic proteinase nepenthesin-1; Nepenthesin-l; & & 1 & 4 & 85.913 & 792 \\
\hline 171 & SCAGHR1018H09.g & Aspartic proteinase nepenthesin-2 OS & Nepenthes gracilis & 1 & 10 & 41.73 & 400 \\
\hline 172 & SCQSRZ3038G01.g & Aspartic proteinase nepenthesin-2 OS & Nepenthes gracilis & 1 & 2 & 26.99 & 252 \\
\hline 173 & SCRFLR2038B01.g & Aspartic proteinase nepenthesin-2; Nepenthesin-II; & & 1 & 10 & 68.461 & 629 \\
\hline 174 & SCVPLR1049D04.g & Aspartic proteinase nepenthesin-2; Nepenthesin-II; & & 2 & 4 & 74.789 & 684 \\
\hline 175 & SCCCRZ2002H06.g & Aspartic proteinase oryzasin 1 precursor (EC 3.4.23.-) & & 1 & 6 & 60.508 & 554 \\
\hline 176 & SCJFRZ2027C07.g & Aspartic proteinase precursor (EC 3.4.23.-) & & 1 & 6 & 59.769 & 544 \\
\hline 177 & SCJFRT2057C03.g & Aspartyl-tRNA synthetase, cytoplasmic OS & Schizosaccharomyces pombe & 13 & 12 & 49.276 & 447 \\
\hline 178 & SCRLLR1038E12.g & ATP phosphoribosyl transferase 1 & & 2 & 6 & 47.578 & 439 \\
\hline 179 & SCACSB1038B04.g & ATP synthase subunit alpha, mitochondrial ATP & & 5 & 12 & 49.768 & 456 \\
\hline 180 & SCCCLB1004B02.g & ATP synthase subunit alpha, mitochondrial & & 2 & 4 & 101.58 & 908 \\
\hline 181 & SCCCRZ2001D06.g & ATP synthase subunit beta, mitochondrial; & & 1 & 10 & 25.314 & 228 \\
\hline 182 & SCVPRT2077G09.g & ATP synthase subunit $d$, mitochondrial OS & Arabidopsis thaliana & 1 & 2 & 23.208 & 206 \\
\hline 183 & SCUTLR1015G10.g & ATP-dependent Clp protease ATP-binding subunit & Solanum lycopersicum & 4 & 8 & 29.854 & 264 \\
\hline 184 & SCVPLR2027A11.g & Auxin-induced in root cultures protein 12 ; & & 2 & 2 & 41.035 & 380 \\
\hline 185 & SCRFLR1012D12.g & auxin & & 29 & 6 & 21.83 & 191 \\
\hline 186 & SCCCCL3003D11.b & B2 protein & & 2 & 15 & 49.745 & 462 \\
\hline 187 & SCCCCL4015F12.g & Basic 7S globulin; SBg7S & & 2 & 3 & 24.396 & 214 \\
\hline 188 & SCQSRT2031A09.g & benzothiadiazole-induced protein-like & Oryza sativa Japonica Group & 2 & 3 & 39.696 & 356 \\
\hline 189 & SCJLRT1022G03.g & beta-1,3-glucanase Glycosyl hydrolases family 17 & & 3 & 13 & 35.498 & 334 \\
\hline 190 & SCCCRT2004A03.g & beta-1,3-glucanase Glycosyl hydrolases family 17 & & 2 & 19 & 45.097 & 419 \\
\hline 191 & SCEQRT1025C10.g & beta-1,3-glucanase Glycosyl hydrolases family 17 & & 1 & 2 & 25.549 & 223 \\
\hline 192 & SCEQRT1026E05.g & beta-1,3-glucanase Glycosyl hydrolases family 17 & & 5 & 4 & 28.887 & 266 \\
\hline 193 & SCEZHR1088G11.g & beta-1,3-glucanase Glycosyl hydrolases family 17 & & 1 & 8 & 36.915 & 334 \\
\hline 194 & SCJFRT1008G05.g & beta-1,3-glucanase Glycosyl hydrolases family 17 & & 1 & 1 & 54.096 & 471 \\
\hline 195 & SCQSRT2031D12.g & beta-1,3-glucanase Glycosyl hydrolases family 17 & & 2 & 5 & 68.701 & 621 \\
\hline 196 & SCRFAM2071E02.g & beta-1,3-glucanase Glycosyl hydrolases family 17 & & 2 & 3 & 33.642 & 301 \\
\hline 197 & SCRFLR1055B07.g & beta-1,3-glucanase Glycosyl hydrolases family 17 & & 1 & 7 & 65.202 & 581 \\
\hline 198 & SCRURT2006B10.g & beta-1,3-glucanase Glycosyl hydrolases family 17 & & 1 & 2 & 79.89 & 734 \\
\hline 199 & SCVPAM1059E12.g & beta-1,3-glucanase Glycosyl hydrolases family 17 & & 1 & 4 & 43.409 & 408 \\
\hline 200 & SCUTAM2089E05.g & beta-amylase & Zea mays & 1 & 2 & 41.119 & 388 \\
\hline 201 & SCCCST3006A04.g & Beta-fructofuranosidase 1 OS & Zea mays & 2 & 3 & 29.327 & 263 \\
\hline 202 & SCCCCL4001H11.g & Beta-galactosidase & & 2 & 16 & 110.68 & 1003 \\
\hline 203 & SCCCCL6004H07.g & Beta-galactosidase & & 2 & 3 & 59.127 & 535 \\
\hline 204 & SCEPRT2044F09.g & Beta-galactosidase & & 1 & 2 & 70.254 & 627 \\
\hline 205 & SCACLR2007C03.g & Beta-like / RACK (Receptor for activated C-kinase) & & 1 & 5 & 41.314 & 366 \\
\hline 206 & SCEZRT2017A05.g & Beta-ureidopropionase OS & Dictyostelium discoideum & 2 & 6 & 30.965 & 285 \\
\hline 207 & SCQSRT1035F11.g & Beta-ureidopropionase OS & Dictyostelium discoideum & 2 & 8 & 46.003 & 437 \\
\hline 208 & SCCCCL4009F05.g & Beta-xylosidase/alpha-L-arabinofuranosidase (GH family 3 ) & & 1 & 2 & 53.886 & 481 \\
\hline 209 & SCQSAM1030G04.g & Beta-xylosidase/alpha-L-arabinofuranosidase (GH family 3 ) & & 2 & 3 & 23.626 & 206 \\
\hline 210 & SCCCRZ1C01F02.g & Bicarbonate (HCO3-) transporter (HCO3_cotransp) & & 1 & 11 & 72.504 & 660 \\
\hline 211 & SCEQRT1028H06.g & Bifunctional nitrilase/nitrile hydratase NIT4 OS & Oryza sativa subsp. japonica & 1 & 6 & 50.767 & 464 \\
\hline 212 & SCACSB1035G04.g & Bifunctional nitrilase/nitrile hydratase NIT4B OS & Nicotiana tabacum & 1 & 6 & 56.118 & 502 \\
\hline 213 & SCCCLR1075F03.g & Bifunctional purple acid phosphatase 26 OS & Arabidopsis thaliana & 1 & 2 & 61.814 & 558 \\
\hline 214 & SCEQLR1091F02.g & Bifunctional purple acid phosphatase 26 OS & Arabidopsis thaliana & 2 & 3 & 48.005 & 442 \\
\hline 215 & SCCCRT1004C05.g & Blue copper protein OS & Pisum sativum & 3 & 5 & 47.92 & 444 \\
\hline 216 & SCAGLR2018C03.g & Blue copper protein; & & 1 & 4 & 33.476 & 309 \\
\hline 217 & SCJFRT2055C03.g & Blue copper protein; & & 1 & 3 & 113.11 & 1028 \\
\hline 218 & SCAGLB2046F01.g & Bowman-Birk type bran trypsin inhibitor precursor & & 1 & 3 & 60.4 & 535 \\
\hline 219 & SCEPLR1051F11.g & Brefeldin A-inhibited guanine nucleotide-exchange protein & & 1 & 2 & 94.955 & 840 \\
\hline 220 & SCRFLR1012F12.g & caffeic acid 3-O-methyltransferase & & 1 & 5 & 35.169 & 323 \\
\hline 221 & SCCCLR1069B09.g & caffeoyl-CoA 3-O-methyltransferase & & 3 & 9 & 126.2 & 1150 \\
\hline 222 & SCJFRZ2010H06.g & caffeoyl-CoA 3-O-methyltransferase & & 1 & 13 & 72.85 & 673 \\
\hline 223 & SCJFRZ2025A01.g & Calcium-dependent protein kinase $2 \mathrm{OS}$ & Arabidopsis thaliana & 1 & 5 & 35.391 & 324 \\
\hline 224 & SCEPRZ1009A12.g & calcium-related & & 4 & 7 & 25.044 & 224 \\
\hline 225 & SCRULR1020G01.g & Calcium/calmodulin-dependent serine/threonine-protein & Oryza sativa subsp. japonica & 7 & 10 & 64.782 & 601 \\
\hline 226 & SCJLHR1028B09.g & Calmodulin OS & Hordeum vulgare & 1 & 3 & 52.13 & 504 \\
\hline 227 & SCCCCL2001B01.b & calmodulin-binding protein & & 3 & 8 & 29.808 & 272 \\
\hline 228 & SCCCCL3001F05.g & calmodulin-binding protein & & 2 & 13 & 68.825 & 632 \\
\hline 229 & SCVPLR1049C09.g & calmodulin-binding protein & & 2 & 5 & 39.861 & 380 \\
\hline 230 & SCCCLR1070F12.g & calnexin & & 4 & 3 & 29.915 & 280 \\
\hline 231 & SCMCST1051F07.g & Calreticulin OS & Oryza sativa subsp. japonica & 2 & 2 & 18.938 & 167 \\
\hline 232 & SCSGST1072D03.g & Calreticulin OS & Oryza sativa subsp. japonica & 1 & 13 & 44.418 & 400 \\
\hline 233 & SCSBRZ3125A08.g & Calreticulin-3 OS & Arabidopsis thaliana & 1 & 1 & 31.415 & 285 \\
\hline 234 & SCACLR1036E03.g & calreticulin & & 1 & 1 & 65.064 & 600 \\
\hline 235 & SCEPLR1051D05.g & calreticulin & & 1 & 27 & 92.895 & 843 \\
\hline 236 & SCCCLR1C02F11.g & Carbon fixation & & 3 & 4 & 35.155 & 344 \\
\hline 237 & SCCCRZ1001B08.g & Carbon fixation & & 3 & 21 & 54.514 & 485 \\
\hline 238 & SCCCRZ1002E05.g & Carbon fixation & & 4 & 7 & 50.201 & 429 \\
\hline 239 & SCQSLR1090G03.g & Carbon fixation & & 1 & 4 & 8.2513 & 69 \\
\hline 240 & SCRLSB1044F02.g & Carbon fixation & & 1 & 1 & 20.504 & 198 \\
\hline 241 & SCCCLB1C03G10.g & Carboxyvinyl-carboxyphosphonate phosphorylmutase & & 2 & 8 & 47.836 & 438 \\
\hline 242 & SCCCLR1001E08.g & Carboxyvinyl-carboxyphosphonate phosphorylmutase & & 1 & 2 & 24.532 & 220 \\
\hline 243 & SCCCCL4017C03.g & casein kinase & & 1 & 7 & 54.838 & 510 \\
\hline 244 & SCCCRZ2002F06.g & Casein kinases & & 2 & 4 & 20.069 & 183 \\
\hline 245 & SCEPRZ1009H01.g & Catalase isozyme $1 \mathrm{OS}$ & Zea mays & 1 & 4 & 40.212 & 357 \\
\hline 246 & SCCCLR1048H09.g & Catalase isozyme 3 OS & Zea mays & 1 & 2 & 27.536 & 260 \\
\hline 247 & SCCCLB1023F09.g & Cathepsin B (Fragment) & & 2 & 1 & 21.721 & 204 \\
\hline 248 & SCCCRZ2C04F03.g & Cation efflux family (Cation_efflux) & & 1 & 1 & 42.37 & 393 \\
\hline 249 & SCCCRZ1003A10.g & Cell division control protein 48 homolog E OS & Arabidopsis thaliana & 2 & 2 & 25.479 & 229 \\
\hline 250 & SCCCLR1076E03.g & Cell elongation protein DIMINUTO OS & Arabidopsis thaliana & 2 & 2 & 12.365 & 116 \\
\hline 251 & SCCCCL5071D07.g & cell wall invertase & & 1 & 6 & 45.622 & 414 \\
\hline 252 & SCCCRT2002B02.g & cell wall invertase & & 1 & 3 & 39.87 & 350 \\
\hline
\end{tabular}


Continuaçao Anexo 2.

\begin{tabular}{|c|c|c|c|c|c|c|c|}
\hline 253 & SCSGSB1008E01.g & cell wall invertase & & 1 & 3 & 14.492 & 137 \\
\hline 254 & SCVPRT3086D06.g & cell wall invertase & & 2 & 3 & 36.301 & 332 \\
\hline 255 & SCACAD1035F09.g & Cellulose synthase (CesA) & & 1 & 1 & 23.592 & 221 \\
\hline 256 & SCSGHR1071F01.g & Cellulose synthase (CesA) & & 3 & 3 & 14.446 & 130 \\
\hline 257 & SCCCLR1C03G09.g & chalcone isomerase $\mathrm{A}$ & & 2 & 14 & 61.388 & 554 \\
\hline 258 & SCEPAM1053F09.g & Chalcone--flavonone isomerase $2 \mathrm{OS}$ & Chrysanthemum morifolium & 6 & 2 & 12.235 & 119 \\
\hline 259 & SCMCAM2080D01.b & Chalcone--flavonone isomerase OS & Gentiana triflora & 1 & 3 & 36.362 & 337 \\
\hline 260 & SCVPRT2078D02.g & Chaperonin CPN60-1, mitochondrial OS & Zea mays & 1 & 9 & 39.663 & 362 \\
\hline 261 & SCCCRZ1003A03.g & chaperonin & & 2 & 3 & 68.171 & 617 \\
\hline 262 & SCRFHR1006G03.g & Chemocyanin precursor (Basic blue protein) (Plantacyanin) & & 3 & 6 & 15.392 & 134 \\
\hline 263 & SCRFRZ3055F03.g & Chemocyanin precursor (Basic blue protein) (Plantacyanin) & & 3 & 4 & 18.07 & 175 \\
\hline 264 & SCQGRT3044B10.g & Chitinase 2 OS & Tulipa bakeri & 2 & 4 & 20.969 & 189 \\
\hline 265 & SCEQLB1067D10.g & chitinase & & 1 & 17 & 40.502 & 372 \\
\hline 266 & SCJLRT1020F06.g & chitinase & & 1 & 11 & 30.79 & 277 \\
\hline 267 & SCQSRT1036B10.g & chitinase & & 3 & 2 & 26.191 & 246 \\
\hline 268 & SCSBFL4014A04.g & Choline transporter-like protein $2 \mathrm{OS}$ & Dictyostelium discoideum GN & 3 & 2 & 14.419 & 135 \\
\hline 269 & SCJFRZ2025G05.g & chorismate mutase & & 4 & 10 & 121.56 & 1091 \\
\hline 270 & SCCCLR1C06B07.g & Chorismate synthase 1, chloroplast precursor (EC 4.2.3.5) & & 1 & 10 & 41.809 & 384 \\
\hline 271 & SCCCCL5004D04.g & Cinnamoyl CoA reductase (CCR) & & 1 & 3 & 69.455 & 640 \\
\hline 272 & SCCCCL2001A05.b & Citrate cycle (TCA cycle) & & 2 & 8 & 37.166 & 326 \\
\hline 273 & SCCCCL3001B09.b & Citrate cycle (TCA cycle) & & 1 & 12 & 38.389 & 351 \\
\hline 274 & SCCCCL4004G06.g & Citrate cycle (TCA cycle) & & 1 & 2 & 44.493 & 392 \\
\hline 275 & SCCCCL7C03F06.g & Citrate cycle (TCA cycle) & & 2 & 5 & 39.348 & 342 \\
\hline 276 & SCCCLR1022D04.g & Citrate cycle (TCA cycle) & & 2 & 3 & 52.226 & 465 \\
\hline 277 & SCCCLR1024D12.g & Citrate cycle (TCA cycle) & & 1 & 9 & 44.634 & 416 \\
\hline 278 & SCCCLR1C06C11.g & Citrate cycle (TCA cycle) & & 1 & 1 & 23.038 & 212 \\
\hline 279 & SCEZRZ1012A01.g & Citrate cycle (TCA cycle) & & 1 & 23 & 101.66 & 893 \\
\hline 280 & SCJLRZ1024A01.g & Citrate cycle (TCA cycle) & & 6 & 3 & 29.456 & 270 \\
\hline 281 & SCUTLR1058B04.g & Citrate cycle (TCA cycle) & & 1 & 11 & 40.634 & 366 \\
\hline 282 & SCVPLR2012F11.g & Citrate cycle (TCA cycle) & & 6 & 6 & 16.213 & 145 \\
\hline 283 & SCCCCL3001C03.g & Citrate synthase 4 , mitochondrial OS & Arabidopsis thaliana & 20 & 6 & 16.288 & 157 \\
\hline 284 & SCCCCL3003F11.b & Citrate synthase, glyoxysomal; GCS; & & 2 & 5 & 22.842 & 204 \\
\hline 285 & SCCCRZ2002F04.g & Clathrin heavy chain & & 3 & 8 & 40.164 & 368 \\
\hline 286 & SCJFRZ2011F04.g & Coatomer subunit beta-2; Beta-coat protein 2; Beta-COP 2 & & 1 & 1 & 38.209 & 347 \\
\hline 287 & SCBFLR1026E07.g & Coatomer subunit gamma-2 OS & Oryza sativa subsp. japonica & 1 & 14 & 43.381 & 401 \\
\hline 288 & SCQGLR1041H02.g & Copper methylamine oxidase; Primary amine oxidase & & 1 & 2 & 33.149 & 317 \\
\hline 289 & SCMCRT2103A12.g & Cortical cell-delineating protein OS & Zea mays & 1 & 1 & 48.806 & 449 \\
\hline 290 & SCAGLB1070B12.g & Crooked neck-like protein 1; Crooked neck homolog; hCrn & & 1 & 12 & 26.396 & 232 \\
\hline 291 & SCEQRT1025E03.g & $\begin{array}{l}\text { Cystatin-1 precursor (Cystatin I) (Corn kernel cysteine } \\
\text { proteinase inhibitor) }\end{array}$ & & 1 & 6 & 24.535 & 210 \\
\hline 292 & SCCCLR1022B11.g & cysteine protease 1 precursor [Zea mays](NCBI) & & 3 & 3 & 17.008 & 146 \\
\hline 293 & SCCCRZ2001D03.g & Cysteine proteinase 2 OS & Zea mays & 2 & 6 & 54.373 & 507 \\
\hline 294 & SCCCRZ3002G10.g & Cysteine proteinase inhibitor $8 \mathrm{OS}$ & Oryza sativa subsp. japonica & 2 & 6 & 50.331 & 464 \\
\hline 295 & SCMCRT2087B02.g & $\begin{array}{l}\text { Cysteine proteinase inhibitor 8; Oryzacystatin-8; } \\
\text { Oryzacystatin VIII; OC-VIII; }\end{array}$ & & 1 & 1 & 46.198 & 435 \\
\hline 296 & SCCCCL4C01F09.g & Cytochrome b-c1 complex subunit 6; & & 3 & 16 & 43.966 & 391 \\
\hline 297 & SCCCLR1001H04.g & Cytochrome b-c1 complex subunit 7; & & 1 & 7 & 61.876 & 567 \\
\hline 298 & SCUTST3087D11.g & Cytochrome b-c1 complex subunit Rieske, mitochondrial; & & 1 & 13 & 48.538 & 444 \\
\hline 299 & SCQGLR2025G04.g & Cytochrome b5 & & 1 & 5 & 66.459 & 607 \\
\hline 300 & SCUTLR2023F06.g & Cytochrome c OS & Oryza sativa subsp. japonica & 2 & 1 & 26.214 & 254 \\
\hline 301 & SCCCLR1080A05.g & Cytochrome c oxidase subunit 6B OS & Schizosaccharomyces pombe & 1 & 2 & 66.134 & 620 \\
\hline 302 & SCUTLR1058A12.g & Cytochrome c1-1, heme protein, mitochondrial; & & 3 & 16 & 42.299 & 395 \\
\hline 303 & SCQSRT1036G12.g & Cytochrome P450 704C1 OS & Pinus taeda & 2 & 1 & 43.588 & 383 \\
\hline 304 & SCEQRT1026G11.g & $\begin{array}{l}\text { Cytosol aminopeptidase (EC 3.4.11.1) (Leucine } \\
\text { aminopeptidase) }\end{array}$ & & 2 & 5 & 17.187 & 151 \\
\hline 305 & SCJFST1011D09.g & DAG protein, chloroplastic; & & 2 & 9 & 48.487 & 452 \\
\hline 306 & SCCCLR1024D04.g & DCN1-like protein 2; & & 1 & 2 & 69.223 & 655 \\
\hline 307 & SCEZLR1031B12.g & DEAD-box ATP-dependent RNA helicase 27 & & 1 & 7 & 56.528 & 514 \\
\hline 308 & SCCCCL7C03C05.g & Delta-1-pyrroline-5-carboxylate dehydrogenase 12A1, & Arabidopsis thaliana & 5 & 3 & 19.103 & 186 \\
\hline 309 & SCRFLR1012G11.g & development & & 1 & 3 & 47.699 & 458 \\
\hline 310 & SCAGRT2041G07.g & dihydrolipoamide S-acetyltransferase & & 2 & 5 & 108.15 & 988 \\
\hline 311 & SCCCCL4011F04.g & $\begin{array}{l}\text { Dihydrolipoyllysine-residue acetyltransferase component } \\
\text { of pyruvate dehydrogenase complex }\end{array}$ & & 1 & 1 & 53.566 & 475 \\
\hline 312 & SCJFRZ2013A05.g & Dipeptidyl peptidase family member 6 OS & Caenorhabditis elegans & 2 & 1 & 16.584 & 175 \\
\hline 313 & SCCCLB1003G10.g & dirigent-like protein & & 2 & 6 & 50.31 & 461 \\
\hline 314 & SCCCRT3002G10.g & dirigent-like protein & & 2 & 9 & 56.736 & 509 \\
\hline 315 & SCEQRT1027C01.g & dirigent-like protein & & 6 & 3 & 21.868 & 199 \\
\hline 316 & SCEQRT2028C09.g & dirigent-like protein & & 1 & 9 & 29.622 & 273 \\
\hline 317 & SCUTAD1032E08.g & dirigent-like protein & & 2 & 8 & 74.46 & 680 \\
\hline 318 & SCJLRT1021D04.g & dirigent-like protein & & 1 & 9 & 42.387 & 374 \\
\hline 319 & SCJLRT3078H06.g & dirigent-like protein & & 2 & 12 & 38.467 & 358 \\
\hline 320 & SCQGRT3045E03.g & dirigent-like protein & & 3 & 16 & 48.708 & 431 \\
\hline 321 & SCRURT3064D10.g & dirigent-like protein & & 1 & 1 & 29.433 & 268 \\
\hline 322 & SCSGRT2065E10.g & DNA catabolism & & 1 & 2 & 46.455 & 425 \\
\hline 323 & SCAGLR1064G04.g & DNA repair & & 1 & 1 & 40.696 & 375 \\
\hline 324 & SCCCRZ1002B09.g & DnaJ-related protein ZMDJ1 & & 2 & 23 & 51.635 & 475 \\
\hline 325 & SCEQRT2027H04.g & $\begin{array}{l}\text { Dolichyl-diphosphooligosaccharide--protein } \\
\text { glycosyltransferase } 48 \text { kDa subunit }\end{array}$ & & 1 & 2 & 34.056 & 307 \\
\hline 326 & SCAGLR1043C02.g & drought and cold response & & 2 & 8 & 28.916 & 263 \\
\hline 327 & SCCCCL4006G06.g & Drought and cold response & & 3 & 9 & 29.342 & 266 \\
\hline 328 & SCJFLR1013A09.g & drought and cold response & & 1 & 1 & 86.018 & 765 \\
\hline 329 & SCQGLR1062E12.g & drought and cold response & & 3 & 23 & 60.307 & 549 \\
\hline 330 & SCCCRT1002E04.g & Dynamin-2A OS & Arabidopsis thaliana & 1 & 4 & 59.825 & 533 \\
\hline 331 & SCVPCL6064A09.g & E3 ubiquitin-protein ligase BRE1-like 1 & & 1 & 8 & 27.951 & 253 \\
\hline 332 & SCRFLR1034C04.g & E3 ubiquitin-protein ligase LRSAM1 & & 2 & 5 & 56.481 & 493 \\
\hline
\end{tabular}


Continuaçao Anexo 2.

\begin{tabular}{|c|c|c|c|c|c|c|c|}
\hline 333 & SCCCCL3003A04.b & E3 ubiquitin-protein ligase RGLG2 OS & Arabidopsis thaliana & 1 & 2 & 32.386 & 298 \\
\hline 334 & SCCCRZ1004D08.g & E3 ubiquitin-protein ligase RGLG2; RING domain ligase 2 & & 1 & 1 & 27.532 & 253 \\
\hline 335 & SCCCCL3004F01.b & Elongation factor 1-alpha OS & Zea mays & 2 & 4 & 49.017 & 457 \\
\hline 336 & SCEQLR1050G05.g & Elongation factor 1-beta OS & Oryza sativa subsp. japonica & 1 & 2 & 45.76 & 416 \\
\hline 337 & SCQSST1040E11.g & Elongation factor 1-beta OS & Oryza sativa subsp. japonica & 2 & 5 & 84.91 & 773 \\
\hline 338 & SCCCLR1048B12.g & Elongation factor 1-gamma 2 OS & Oryza sativa subsp. japonica & 3 & 2 & 22.949 & 206 \\
\hline 339 & SCEQLR1050E07.g & Elongation factor 1-gamma $2 \mathrm{OS}$ & Oryza sativa subsp. japonica & 2 & 3 & 50.844 & 456 \\
\hline 340 & SCSBFL1107A09.g & Elongation factor 1-gamma 2 OS & Oryza sativa subsp. japonica & 1 & 5 & 41.526 & 385 \\
\hline 341 & SCCCLR1072F05.g & Elongation factor 2 OS & Beta vulgaris & 1 & 4 & 28.115 & 244 \\
\hline 342 & SCCCLR2C01H02.g & Endo-1,3;1,4-beta-D-glucanase OS & Zea mays & 1 & 5 & 48.072 & 437 \\
\hline 343 & SCVPRT2081E09.g & Endo-1,3(4)-beta-glucanase 1 & & 1 & 1 & 35.822 & 331 \\
\hline 344 & SCUTLR2030G02.g & endo-1,4-beta-glucanase Glycosyl hydrolase family 9 & & 1 & 12 & 20.057 & 181 \\
\hline 345 & SCCCCL3005G07.b & Endoplasmin homolog OS & Arabidopsis thaliana & 4 & 11 & 35.989 & 347 \\
\hline 346 & SCCCLR1068D10.g & Endoplasmin homolog; GRP94 homolog; & & 2 & 4 & 39.081 & 366 \\
\hline 347 & SCJFLR1073H09.g & enolase 1 [Zea mays](NCBI) & & 2 & 2 & 40.047 & 377 \\
\hline 348 & SCCCRZ1002F06.g & Enolase 2 OS & Zea mays & 2 & 12 & 93.12 & 810 \\
\hline 349 & SCCCLR1070G05.g & Enolase-phosphatase E1 ( & & 3 & 3 & 28.17 & 257 \\
\hline 350 & SCCCCL7C01H04.g & Epoxide hydrolase 2 OS & Homo sapiens & 5 & 4 & 38.214 & 348 \\
\hline 351 & SCCCLR1072D09.g & Epsilon-COP & & 9 & 10 & 46.067 & 420 \\
\hline 352 & SCUTLR2023A03.g & Esterase precursor (Early nodule-specific protein homolog) & & 1 & 4 & 37.577 & 330 \\
\hline 353 & SCRFLR1055F03.g & ET01-like protein 1; Ethylene overproducer 1-like protein & & 2 & 4 & 57.237 & 527 \\
\hline 354 & SCCCLR1072G07.g & Eukaryotic initiation factor $4 \mathrm{~A}-3 \mathrm{OS}$ & Oryza sativa subsp. japonica & 2 & 3 & 27.679 & 248 \\
\hline 355 & SCRFLR1012B11.g & Eukaryotic initiation factor iso-4F subunit p82-34 OS & Triticum aestivum & 2 & 9 & 70.283 & 629 \\
\hline 356 & SCCCCL4005C02.g & Eukaryotic translation initiation factor 2 subunit 3 OS & Rattus norvegicus & 1 & 10 & 61.449 & 559 \\
\hline 357 & SCCCCL6005C02.g & Eukaryotic translation initiation factor 2 subunit alpha OS & Schizosaccharomyces pombe & 1 & 4 & 53.117 & 501 \\
\hline 358 & SCQGLR1019B10.g & Eukaryotic translation initiation factor 3 subunit 9 & & 10 & 14 & 47.085 & 436 \\
\hline 359 & SCSGAD1006A07.g & Eukaryotic translation initiation factor 3 subunit G OS & Xenopus tropicalis & 2 & 3 & 45.655 & 402 \\
\hline 360 & SCSFAM1075C08.g & Eukaryotic translation initiation factor 3 subunit I OS & Arabidopsis thaliana & 1 & 2 & 37.435 & 338 \\
\hline 361 & SCCCLR1C10C03.g & Eukaryotic translation initiation factor 3 subunit J & & 4 & 12 & 61.595 & 568 \\
\hline 362 & SCCCLR1001G08.g & Eukaryotic translation initiation factor $5 \mathrm{OS}$ & Zea mays & 5 & 35 & 93.883 & 843 \\
\hline 363 & SCSBFL5022C12.g & Eukaryotic translation initiation factor $5 \mathrm{~A}$ OS & Zea mays & 5 & 16 & 46.719 & 411 \\
\hline 364 & SCCCLR1070E06.g & Eukaryotic translation initiation factor $5 \mathrm{~A}-1 / 2$ (elF-5A $1 / 2$ ) & & 1 & 5 & 21.504 & 195 \\
\hline 365 & SCACLV1022D02.g & exoglucanase & & 1 & 2 & 72.762 & 666 \\
\hline 366 & SCJLRT1018C07.g & Exosome complex exonuclease RRP42 & & 12 & 4 & 22.52 & 203 \\
\hline 367 & SCCCCL3120E05.g & Expansin & & 4 & 11 & 75.779 & 659 \\
\hline 368 & SCCCCL4006H09.g & Expansin & & 1 & 2 & 27.807 & 250 \\
\hline 369 & SCCCLR1065A10.g & Expansin & & 2 & 9 & 62.706 & 582 \\
\hline 370 & SCEPRT2043B01.g & Expansin & & 2 & 3 & 71.144 & 619 \\
\hline 371 & SCSGLV1004F11.g & Expansin & & 2 & 3 & 21.12 & 195 \\
\hline 372 & SCJLRZ1019F12.g & Expansin & & 1 & 2 & 45.433 & 411 \\
\hline 373 & SCQGAM2029E05.g & Exportin-4; Exp4 & & 1 & 9 & 41.327 & 380 \\
\hline 374 & SCCCCL4007A08.g & F-box/LRR-repeat protein 15 & & 1 & 5 & 36.128 & 333 \\
\hline 375 & SCCCLR1072G10.g & F24J8.10 protein & & 1 & 1 & 32.218 & 303 \\
\hline 376 & SCVPRZ2036H04.g & Farnesyl pyrophosphate synthetase & & 1 & 14 & 48.104 & 454 \\
\hline 377 & SCEPLR1030C10.g & Fasciclin-like arabinogalactan protein 16; & & 1 & 4 & 23.81 & 227 \\
\hline 378 & SCCCCL7001H04.g & Fasciclin-like arabinogalactan protein & & 1 & 13 & 46.848 & 435 \\
\hline 379 & SCEPLR1051B04.g & Fasciclin-like arabinogalactan protein & & 4 & 3 & 10.243 & 92 \\
\hline 380 & SCQGRT1040D08.g & Fasciclin-like arabinogalactan protein & & 2 & 6 & 34.545 & 320 \\
\hline 381 & SCQSLR1040G04.g & Fasciclin-like arabinogalactan protein & & 1 & 6 & 59.01 & 549 \\
\hline 382 & SCRFLR1034D04.g & Fasciclin-like arabinogalactan protein & & 1 & 5 & 68.999 & 626 \\
\hline 383 & SCVPRZ2036F10.g & Fasciclin-like arabinogalactan protein & & 3 & 10 & 51.792 & 472 \\
\hline 384 & SCEQRT1028D11.g & Fatty acid oxidation complex subunit alpha; & & 7 & 11 & 45.965 & 417 \\
\hline 385 & SCCCRZ2C01H04.g & Ferritin-1, chloroplastic OS & Zea mays & 1 & 3 & 35.912 & 327 \\
\hline 386 & SCSFHR1046G01.g & FK506-binding protein 2-1 precursor (EC 5.2.1.8) & & 5 & 4 & 17.584 & 165 \\
\hline 387 & SCVPRT2081D11.g & Flavoprotein wrbA (Trp repressor-binding protein) & & 1 & 5 & 30.533 & 284 \\
\hline 388 & SCEZRZ1012E05.g & Formamidase OS & Methylophilus methylotrophus GI & 1 & 1 & 28.275 & 271 \\
\hline 389 & SCJLRZ1021E10.g & Fructokinase-2 OS & \begin{tabular}{|c|} 
Zea mays \\
\end{tabular} & 3 & 5 & 58.472 & 522 \\
\hline 390 & SCRFLR1012E06.g & Fructokinase & & 4 & 4 & 22.65 & 210 \\
\hline 391 & SCCCCL4011H08.g & Fructose and Mannose Metabolism & & 2 & 6 & 32.021 & 297 \\
\hline 392 & SCCCLR1048B08.g & Fructose and Mannose Metabolism & & 1 & 6 & 16.837 & 158 \\
\hline 393 & SCEPRZ1009B12.g & Fructose and Mannose Metabolism & & 4 & 8 & 93.492 & 843 \\
\hline 394 & SCJLFL3019C04.g & Fructose and Mannose Metabolism & & 1 & 2 & 50.778 & 462 \\
\hline 395 & SCCCCL3120C03.g & Fructose-bisphosphate aldolase cytoplasmic isozyme OS & Oryza sativa subsp. japonica & 3 & 2 & 17.434 & 154 \\
\hline 396 & SCCCRZ2001F03.g & Fructose-bisphosphate aldolase, cytoplasmic isozyme OS & Zea mays & 1 & 2 & 47.131 & 444 \\
\hline 397 & SCSGRT2066A01.g & fumarylacetoacetase & & 3 & 1 & 12.955 & 128 \\
\hline 398 & SCVPCL6043F04.g & Fumarylacetoacetate hydrolase domain-containing protein & Dictyostelium discoideum & 2 & 21 & 61.099 & 559 \\
\hline 399 & SCRLLB2031A09.g & FUS-interacting serine-arginine-rich protein 1 & & 2 & 5 & 24.333 & 204 \\
\hline 400 & SCCCRZ1001D04.g & Galactose metabolism & & 1 & 21 & 46.031 & 412 \\
\hline 401 & SCEQRT1026G06.g & Galactose metabolism & & 1 & 5 & 23.475 & 206 \\
\hline 402 & SCCCAM2C06F04.g & Galactosyltransferase & & 2 & 1 & 15.728 & 133 \\
\hline 403 & SCCCLR1C07B06.g & Gamma-glutamyl hydrolase & & 2 & 7 & 24.564 & 216 \\
\hline 404 & SCQGLR2025D03.g & gamma-glutamylcysteine synthetase 1 & & 2 & 18 & 36.063 & 336 \\
\hline 405 & SCJFRT1012G05.g & Gamma-glutamyltranspeptidase $1 \mathrm{OS}$ & Schizosaccharomyces pombe & 1 & 4 & 12.5 & 111 \\
\hline 406 & SCBFRZ2018D11.g & Gamma-interferon-inducible lysosomal thiol reductase OS & Homo sapiens & 1 & 5 & 41.807 & 370 \\
\hline 407 & SCQSRT3055D04.g & GDSL esterase/lipase 5 OS & Arabidopsis thaliana & 1 & 3 & 56.595 & 526 \\
\hline 408 & SCCCCL7001H09.g & GDSL esterase/lipase At5g45910 OS & Arabidopsis thaliana & 1 & 20 & 65.953 & 608 \\
\hline 409 & SCCCRZ1002D12.g & GDSL esterase/lipase At5g45910 OS & Arabidopsis thaliana & 1 & 1 & 42.553 & 385 \\
\hline 410 & SCVPRT2083D11.g & Germin-like protein 8-13 OS & Oryza sativa subsp. japonica & 1 & 2 & 87.178 & 801 \\
\hline 411 & SCCCRT1C01G07.g & Germin-like protein 8-5 OS & Oryza sativa subsp. japonica & 5 & 3 & 29.727 & 263 \\
\hline 412 & SCJFRT1058A06.g & Germin-like protein subfamily T member 1 precursor & & 1 & 1 & 24.741 & 223 \\
\hline 413 & SCJLRT2050A02.g & GLABRA2 expression modulator & & 2 & 6 & 35.794 & 326 \\
\hline 414 & SCCCLB1024G12.g & Glucosidase 2 subunit beta precursor & & 6 & 10 & 56.837 & 514 \\
\hline 415 & SCCCLR2C03C10.g & glucosyltransferase & & 1 & 3 & 39.003 & 348 \\
\hline 416 & SCJFRZ2007H09.g & Glutamate decarboxylase $1 \mathrm{OS}$ & Arabidopsis thaliana & 2 & 27 & 42.603 & 385 \\
\hline 417 & SCCCCL3080H03.g & Glutamate dehydrogenase OS & Zea mays & 1 & 1 & 43.336 & 381 \\
\hline
\end{tabular}


Continuaçao Anexo 2.

\begin{tabular}{|c|c|c|c|c|c|c|c|}
\hline 418 & SCJFLR1013F02.g & Glutamine synthetase cytosolic isozyme 1-1 & & 2 & 3 & 41.236 & 368 \\
\hline 419 & SCCCRZ1004H06.g & Glutaredoxin & & 1 & 2 & 18.487 & 167 \\
\hline 420 & SCCCRT1003F01.g & Glutathione reductase, cytosolic; GRase; GR & & 1 & 3 & 29.49 & 264 \\
\hline 421 & SCAGFL1089C03.g & Glutathione S-transferase 1 OS & Zea mays & 1 & 4 & 18.394 & 172 \\
\hline 422 & SCCCLR1001A07.g & Glutathione S-transferase 3 OS & Zea mays & 2 & 10 & 23.394 & 209 \\
\hline 423 & SCJLRT1021D09.g & Glutathione S-transferase 4 OS & Zea mays & 2 & 7 & 134.3 & 1232 \\
\hline 424 & SCQSLB1049C04.g & Glutathione S-transferase 6, chloroplast precursor & & 1 & 4 & 22.672 & 208 \\
\hline 425 & SCCCCL3002A02.b & Glutathione S-transferase DHAR1, mitochondrial OS & Arabidopsis thaliana & 2 & 2 & 51.264 & 468 \\
\hline 426 & SCVPLR2012H12.g & glutathione S-transferase GST 12 & & 2 & 6 & 16.72 & 148 \\
\hline 427 & SCJLST1027D09.g & Glutathione S-transferase; GST class-phi & & 1 & 3 & 15.09 & 134 \\
\hline 428 & SCACLR2014B06.g & glutathione S-transferase & & 1 & 8 & 45.1 & 405 \\
\hline 429 & SCCCCL3002C09.b & glutathione S-transferase & & 3 & 4 & 64.073 & 568 \\
\hline 430 & SCCCLR1072B04.g & Glyceraldehyde-3-phosphate dehydrogenase, cytosolic 1 & Zea mays & 1 & 9 & 49.54 & 435 \\
\hline 431 & SCBFRZ2050G03.g & Glycine cleavage system $\mathrm{H}$ protein, mitochondrial & Flaveria pubescens & 1 & 1 & 17.609 & 156 \\
\hline 432 & SCCCLR1022F10.g & glycine metabolism & & 3 & 3 & 72.373 & 673 \\
\hline 433 & SCCCRZ1004F05.g & glycolysis & & 2 & 15 & 33.856 & 295 \\
\hline 434 & SCEPRZ3047F05.g & glycolysis & & 3 & 7 & 30.668 & 286 \\
\hline 435 & SCCCLR1001E06.g & Glycolysis/Gluconeogenesis & & 2 & 3 & 18.334 & 171 \\
\hline 436 & SCCCLR1079B06.g & Glycolysis/Gluconeogenesis & & 1 & 3 & 68.512 & 606 \\
\hline 437 & SCCCRZ1001C05.g & Glycolysis/Gluconeogenesis & & 2 & 4 & 20.868 & 191 \\
\hline 438 & SCJFLR1013B03.g & Glycolysis/Gluconeogenesis & & 1 & 3 & 20.336 & 184 \\
\hline 439 & SCJFRZ3C01H09.g & Glycoside hydrolase family 28 protein (polygalacturonase) & & 1 & 3 & 25.504 & 239 \\
\hline 440 & SCJFRZ2029F03.g & $\begin{array}{l}\text { Glycoside hydrolase family } 31 \text { (alpha-glucosidase or alpha- } \\
\text { xylosidase) }\end{array}$ & & 3 & 1 & 20.813 & 196 \\
\hline 441 & SCAGLR1021F11.g & Glycosyl hydrolase family 1 & & 2 & 3 & 17.241 & 153 \\
\hline 442 & SCCCCL3001B10.b & Glycosyl hydrolase family 1 & & 3 & 5 & 19.647 & 176 \\
\hline 443 & SCEQHR1082B01.g & Glycosyl hydrolase family 1 & & 1 & 1 & 11.198 & 97 \\
\hline 444 & SCEQLB1066E08.g & Glycosyl hydrolase family 1 & & 2 & 4 & 64.674 & 612 \\
\hline 445 & SCJFLR1017E03.g & Glycosyl hydrolase family 1 & & 1 & 2 & 20.847 & 192 \\
\hline 446 & SCAGRT2037A11.g & Glycosyl hydrolase family 3 protein (Xylosidase) & & 1 & 6 & 26.85 & 239 \\
\hline 447 & SCCCRT1002G03.g & Glycosyl hydrolase family 3 protein (Xylosidase) & & 1 & 1 & 17.127 & 148 \\
\hline 448 & SCCCSB1003H06.g & Glycosyl hydrolase family 3 protein (Xylosidase) & & 1 & 2 & 56.748 & 536 \\
\hline 449 & SCEZRZ3015A12.g & Glycosyl hydrolase family 3 protein (Xylosidase) & & 1 & 2 & 15.931 & 157 \\
\hline 450 & SCEQLR1093F09.g & glycosyl hydrolase family 3 protein & & 2 & 2 & 18.29 & 174 \\
\hline 451 & SCEZLB1007A09.g & glycosyl hydrolase family 3 protein & & 1 & 52 & 105.63 & 940 \\
\hline 452 & SCRURT2008D11.g & glycosyl hydrolase family 3 protein & & 3 & 2 & 13.027 & 127 \\
\hline 453 & SCCCCL2001B11.b & $\begin{array}{l}\text { Glycosyl hydrolases family } 18 \text { (probable chitinase or } \\
\text { xylanase inibitor) }\end{array}$ & & 3 & 13 & 33.511 & 324 \\
\hline 454 & SCCCCL4003F09.g & $\begin{array}{l}\text { Glycosyl hydrolases family } 18 \text { (probable chitinase or } \\
\text { xylanase inibitor) }\end{array}$ & & 1 & 9 & 24.867 & 228 \\
\hline 455 & SCEZLB1007H04.g & $\begin{array}{l}\text { Glycosyl transferase family } 8 \text { (lipopolysaccharide } \\
\text { biosynthesis) }\end{array}$ & & 2 & 4 & 74.162 & 679 \\
\hline 456 & SCQSRT2036H09.g & Glycylpeptide N-tetradecanoyltransferase 1 OS & Arabidopsis thaliana & 2 & 2 & 56.317 & 503 \\
\hline 457 & SCVPCL6041A10.g & Glycylpeptide N-tetradecanoyltransferase 1 & & 1 & 7 & 49.099 & 445 \\
\hline 458 & SCBFST3133F03.g & GTP-binding protein YPTM1 & & 1 & 2 & 112.72 & 1023 \\
\hline 459 & SCJFRZ2013H05.g & $\begin{array}{l}\text { Haloacid dehalogenase-like hydrolase domain-containing } \\
\text { protein } 3\end{array}$ & & 1 & 4 & 64.937 & 591 \\
\hline 460 & SCRFLR2038F04.g & Heat shock $70 \mathrm{kDa}$ protein $4 \mathrm{~L}$ OS & Mus musculus & 1 & 2 & 33.834 & 307 \\
\hline 461 & SCCCLR1080E07.g & Heat shock 70 kDa protein, mitochondrial; & & 1 & 3 & 20.461 & 190 \\
\hline 462 & SCCCRZ1002G01.g & Heat shock cognate $70 \mathrm{kDa}$ protein $2 \mathrm{OS}$ & Solanum lycopersicum & 2 & 12 & 60.003 & 559 \\
\hline 463 & SCCCLR1075E09.g & Heat shock protein 81-1 OS & Oryza sativa subsp. japonica & 1 & 2 & 44.207 & 399 \\
\hline 464 & SCJLLR1011E03.g & Heat shock protein 81-1 OS & Oryza sativa subsp. japonica & 2 & 4 & 19.785 & 203 \\
\hline 465 & SCCCLR2C02F10.g & Heat shock protein 81-3 OS & Oryza sativa subsp. japonica & 1 & 1 & 17.673 & 172 \\
\hline 466 & SCUTST3084B04.g & Heat stress transcription factor B-1 OS & Oryza sativa subsp. japonica & 1 & 2 & 60.974 & 567 \\
\hline 467 & SCSGAM2103F11.g & Heparanase-like protein 1; & & 2 & 2 & 16.063 & 150 \\
\hline 468 & SCEQRT2092B03.g & Heparanase-like protein 2; & & 1 & 2 & 20.737 & 187 \\
\hline 469 & SCMCAM2084F02.g & Hexokinase-5 OS & Oryza sativa subsp. japonica & 1 & 5 & 18.747 & 176 \\
\hline 470 & SCAGAM2124E02.g & Hexokinase-6 OS & Oryza sativa subsp. japonica & 1 & 1 & 71.466 & 639 \\
\hline 471 & SCJFRT2059G11.g & histidinol dehydrogenase & & 1 & 4 & 33.904 & 324 \\
\hline 472 & SCBFRZ2018H11.g & Histone H1 OS & Solanum pennellii PE & 1 & 14 & 45.517 & 422 \\
\hline 473 & SCACFL8019G10.g & Histone $\mathrm{H} 1 \mathrm{OS}$ & Zea mays & 1 & 3 & 19.368 & 180 \\
\hline 474 & SCJFRZ2010B03.g & Histone $\mathrm{H} 1 \mathrm{OS}$ & Zea mays & 1 & 4 & 22.86 & 205 \\
\hline 475 & SCCCLR1001C03.g & Histone H2A OS & Petroselinum crispum & 1 & 11 & 34.065 & 315 \\
\hline 476 & SCQGLR1062G09.g & Histone H2B.2 OS & Oryza sativa subsp. japonica & 2 & 17 & 46.468 & 440 \\
\hline 477 & SCVPLB1017H05.g & Histone H3.2 OS & Triticum aestivum & 3 & 13 & 39.573 & 357 \\
\hline 478 & SCJFRZ2006G04.g & Histone $\mathrm{H} 3.3 \mathrm{OS}$ & Vitis vinifera & 1 & 23 & 64.166 & 592 \\
\hline 479 & SCJLLR2020B06.g & Histone $\mathrm{H} 4 \mathrm{OS}$ & Silene latifolia & 1 & 2 & 22.694 & 207 \\
\hline 480 & SCRFHR1009A01.g & Horcolin OS & Hordeum vulgare & 1 & 2 & 60.16 & 545 \\
\hline 481 & SCRURT3064B04.b & Horcolin OS & Hordeum vulgare & 2 & 3 & 34.087 & 321 \\
\hline 482 & SCEZST3147B03.g & hypothetical protein & Oryza sativa Japonica Group & 1 & 2 & 55.434 & 513 \\
\hline 483 & SCSGRZ3061F11.g & hypothetical protein & Zea mays & 3 & 26 & 57.676 & 532 \\
\hline 484 & SCJLRT1014F08.g & hypothetical protein OsI_12184 & Oryza sativa Indica & 9 & 26 & 74.957 & 686 \\
\hline 485 & SCAGRT2041F12.g & hypothetical protein SORBIDRAFT_01g027670 & Sorghum bicolor & 7 & 31 & 92.942 & 816 \\
\hline 486 & SCQGLB1029D12.g & hypothetical protein SORBIDRAFT_02g007160 & Sorghum bicolor & 1 & 2 & 48.036 & 465 \\
\hline 487 & SCEQRT1024B11.g & hypothetical protein SORBIDRAFT_02g010830 & Sorghum bicolor & 1 & 1 & 29.58 & 271 \\
\hline 488 & SCBGAM1092D06.g & hypothetical protein SORBIDRAFT_03g013250 & Sorghum bicolor & 1 & 14 & 75.685 & 705 \\
\hline 489 & SCCCLB1001G04.g & hypothetical protein SORBIDRAFT_03g027650 & Sorghum bicolor & 1 & 12 & 66.528 & 604 \\
\hline 490 & SCJLRT1014G09.g & hypothetical protein SORBIDRAFT_05g004770 & Sorghum bicolor & 1 & 1 & 22.201 & 207 \\
\hline 491 & SCCCRT1003E03.g & hypothetical protein SORBIDRAFT_05g004770 & Sorghum bicolor & 3 & 2 & 14.572 & 133 \\
\hline 492 & SCJFRT1059C11.g & hypothetical protein SORBIDRAFT_06g022840 & Sorghum bicolor & 1 & 5 & 131.58 & 1187 \\
\hline 493 & SCCCLR1C04C04.g & hypothetical protein SORBIDRAFT_06g028280 & Sorghum bicolor & 3 & 3 & 55.35 & 490 \\
\hline 494 & SCBFRZ2046F03.g & hypothetical protein SORBIDRAFT_07g009530 & Sorghum bicolor & 1 & 1 & 46.768 & 426 \\
\hline 495 & SCQSRT1034A12.g & hypothetical protein SORBIDRAFT_07g022290 & Sorghum bicolor & 1 & 2 & 46.034 & 414 \\
\hline 496 & SCEZRZ3095DD08.g & hypothetical protein SORBIDRAFT_08g000440 & Sorghum bicolor & 3 & 5 & 57.402 & 543 \\
\hline 497 & SCAGFL1089C05.g & hypothetical protein SORBIDRAFT_08g018710 & Sorghum bicolor & 1 & 1 & 58.236 & 511 \\
\hline
\end{tabular}


Continuaçao Anexo 2.

\begin{tabular}{|c|c|c|c|c|c|c|c|}
\hline 498 & SCCCRZ1C01A05.g & Importin alpha 2 subunit (NLS receptor) & & 1 & 2 & 64.009 & 578 \\
\hline 499 & SCCCCL3003D06.b & Importin subunit alpha-1b & & 1 & 8 & 75.119 & 683 \\
\hline 500 & SCQSRT1036H06.g & Importin subunit beta-1 (Karyopherin subunit beta-1) & & 1 & 6 & 65.929 & 602 \\
\hline 501 & SCUTLR2030A05.g & Importin-beta2 & & 1 & 2 & 90.88 & 820 \\
\hline 502 & SCCCRZ1002H11.g & Indole-3-glycerol phosphate synthase, chloroplastic OS & Arabidopsis thaliana & 1 & 3 & 63.607 & 601 \\
\hline 503 & SCBFLR1026E02.g & inositol kinase & & 3 & 11 & 52.889 & 496 \\
\hline 504 & SCCCCL3120F08.b & Inositol phosphatases & & 2 & 3 & 45.279 & 403 \\
\hline 505 & SCCCLR1C02F07.g & Inositol-3-phosphate synthase OS & Zea mays & 1 & 4 & 17.517 & 161 \\
\hline 506 & SCCCRT3007D01.g & Intracellular ribonuclease LX OS & Solanum lycopersicum & 2 & 3 & 21.972 & 201 \\
\hline 507 & SCCCCL4017A09.g & Isocitrate dehydrogenase [NADP], chloroplastic & Medicago sativa & 1 & 2 & 17.813 & 164 \\
\hline 508 & SCCCLR1C04G09.g & Isocitrate dehydrogenase [NADP], chloroplastic & Medicago sativa & 2 & 5 & 39.642 & 366 \\
\hline 509 & SCVPLB1020E05.g & $\begin{array}{l}\text { isoflavone reductase/pinoresinol reductase (lignan } \\
\text { biosynthesis) }\end{array}$ & & 3 & 12 & 59.065 & 553 \\
\hline 510 & SCCCLR1001A04.g & Jasmonate-induced protein homolog & & 1 & 8 & 45.672 & 407 \\
\hline 511 & SCBGRT3075F07.g & Jasmonate & & 4 & 26 & 53.332 & 484 \\
\hline 512 & SCJLRZ1024A04.g & Jasmonate & & 2 & 6 & 20.82 & 182 \\
\hline 513 & SCCCCL4013D09.g & jasmonic acid & & 1 & 9 & 63.894 & 587 \\
\hline 514 & SCCCRT1001E01.g & jasmonic acid & & 1 & 14 & 44.496 & 398 \\
\hline 515 & SCJFRT1007H07.g & jasmonic acid & & 19 & 6 & 33.13 & 303 \\
\hline 516 & SCSBHR1052D02.g & jasmonic acid & & 1 & 6 & 44.545 & 396 \\
\hline 517 & SCUTLR2030B03.g & jasmonic acid & & 1 & 5 & 21.064 & 188 \\
\hline 518 & SCCCLR1024E10.g & Ketol-acid reductoisomerase, chloroplastic OS & Oryza sativa subsp. japonica & 1 & 15 & 33.825 & 311 \\
\hline 519 & SCCCLR1076C03.g & Ketol-acid reductoisomerase, chloroplastic & & 1 & 2 & 71.821 & 645 \\
\hline 520 & SCCCLR1078H05.g & Kynurenine formamidase OS & & 2 & 7 & 119.42 & 1043 \\
\hline 521 & SCCCLR1072E07.g & L-ascorbate peroxidase 1 , cytosolic OS & Oryza sativa subsp. japonica & 1 & 3 & 45.077 & 408 \\
\hline 522 & SCEQRT2096D11.g & laccase-like protein & & 2 & 2 & 27.428 & 246 \\
\hline 523 & SCMCRT2087D02.g & laccase-like protein & & 1 & 4 & 68.037 & 640 \\
\hline 524 & SCQSAD1056B07.b & laccase-like protein & & 1 & 30 & 98.503 & 881 \\
\hline 525 & SCSBAD1050H03.b & laccase-like protein & & 1 & 1 & 20.572 & 189 \\
\hline 526 & SCVPST1060D08.g & laccase-like protein & & 2 & 8 & 46.155 & 417 \\
\hline 527 & SCCCST1002D07.g & Lactoylglutathione lyase OS & Oryza sativa subsp. japonica & 3 & 7 & 21.74 & 204 \\
\hline 528 & SCQGRT1042E05.g & Lactoylglutathione lyase; Methylglyoxalase & & 2 & 4 & 13.705 & 119 \\
\hline 529 & SCRUHR1076B12.g & lactoylglutlactoylglutathione lyase (glyoxalase I) & & 1 & 4 & 23.881 & 213 \\
\hline 530 & SCBGLR1023A04.g & Lamin-like protein OS & Arabidopsis thaliana & 3 & 5 & 20.949 & 187 \\
\hline 531 & SCJLRZ1024H09.g & Late embryogenesis abundant protein Lea14-A OS & Gossypium hirsutum & 4 & 6 & 20.868 & 185 \\
\hline 532 & SCSGST1072B08.g & Leucine aminopeptidase 2 , chloroplastic & & 1 & 2 & 27.508 & 245 \\
\hline 533 & SCCCLR1048G02.g & Leucyl-tRNA synthetase, cytoplasmic OS & & 5 & 43 & 84.452 & 766 \\
\hline 534 & SCSBFL5014H12.g & Lipoxygenase 2 OS & Oryza sativa subsp. japonica & 6 & 8 & 89.097 & 851 \\
\hline 535 & SCBFLR1026B05.g & LL-diaminopimelate aminotransferase, chloroplastic & & 3 & 9 & 36.72 & 343 \\
\hline 536 & SCACLR2029D05.g & LOC100285305 precursor & Zea mays & 1 & 2 & 23.627 & 222 \\
\hline 537 & SCJLLR1054F05.g & Luminal-binding protein $2 \mathrm{OS}$ & Zea mays & 1 & 2 & 54.909 & 495 \\
\hline 538 & SCSFST3076G09.g & Luminal-binding protein 3 OS & Zea mays & 2 & 8 & 14.547 & 136 \\
\hline 539 & SCMCLR1053H06.g & lysyl-tRNA synthetase & & 1 & 4 & 21.957 & 207 \\
\hline 540 & SCMCST1055F02.g & lysyl-tRNA synthetase & & 1 & 1 & 28.445 & 263 \\
\hline 541 & SCCCLR1072A12.g & Malate dehydrogenase, chloroplastic & & 2 & 9 & 37.527 & 344 \\
\hline 542 & SCCCLR1024D03.g & Malate dehydrogenase, cytoplasmic OS & Zea mays & 1 & 4 & 24.201 & 222 \\
\hline 543 & SCCCCL4004C11.g & Malate dehydrogenase, mitochondrial OS & Fragaria ananassa GN & 1 & 5 & 88.905 & 860 \\
\hline 544 & SCCCRZ1002H10.g & Mavicyanin & & 1 & 4 & 13.488 & 122 \\
\hline 545 & SCUTLR2030F05.g & Mediator of RNA polymerase II transcription subunit 32 & & 1 & 2 & 43.806 & 384 \\
\hline 546 & SCRFLR1055B01.g & Methionine aminopeptidase 2B OS & Arabidopsis thaliana & 2 & 5 & 16.646 & 153 \\
\hline 547 & SCEZRZ1012F05.g & Methylenetetrahydrofolate reductase 1; ZmMTHFR1 & & 1 & 2 & 37.208 & 360 \\
\hline 548 & SCVPLR1049C03.g & Methylmalonate-semialdehyde dehydrogenase [acylating] & & 2 & 5 & 61.702 & 558 \\
\hline 549 & SCQGST1031A07.g & Microtubule-associated protein TORTIFOLIA1 OS & Arabidopsis thaliana & 1 & 1 & 27.423 & 249 \\
\hline 550 & SCEQLR1092H08.g & $\begin{array}{l}\text { Mitochondrial import inner membrane translocase subunit } \\
\text { Tim10 }\end{array}$ & & 2 & 1 & 20.166 & 183 \\
\hline 551 & SCVPRT2074F03.g & Mitochondrial import receptor subunit TOM7-1 OS & Solanum tuberosum & 1 & 4 & 54.416 & 477 \\
\hline 552 & SCCCLR1067D05.g & $\begin{array}{l}\text { Voltage-dependent anion-selective channel protein; VDAC; } \\
\text { POM } 36\end{array}$ & & 1 & 3 & 37.268 & 337 \\
\hline 553 & SCCCCL3002B06.b & Mitochondrial outer membrane protein porin OS & Oryza sativa subsp. japonica & 2 & 3 & 58.029 & 523 \\
\hline 554 & SCJFLR1074A12.g & $\begin{array}{l}\text { Mitochondrial outer membrane protein porin; Voltage- } \\
\text { dependent anion-selective channel protein; VDAC }\end{array}$ & & 2 & 8 & 57.883 & 529 \\
\hline 555 & SCCCLR1022A05.g & Mitochondrial-processing peptidase subunit alpha OS & Solanum tuberosum & 2 & 6 & 27.58 & 254 \\
\hline 556 & SCJLRT1021G03.g & Mitochondrial-processing peptidase subunit alpha OS & Solanum tuberosum & 1 & 3 & 27.968 & 254 \\
\hline 557 & SCCCLR2001H12.g & MND1-interacting protein 1 OS & Arabidopsis thaliana & 1 & 5 & 24.013 & 223 \\
\hline 558 & SCCCLR1079D10.g & Monodehydroascorbate reductase OS & Solanum lycopersicum & 1 & 2 & 33.511 & 321 \\
\hline 559 & SCQSRT2036A12.g & Monodehydroascorbate reductase OS & Solanum lycopersicum & 2 & 2 & 14.731 & 140 \\
\hline 560 & SCQSRT2031F03.g & Monodehydroascorbate reductase, chloroplastic OS & Arabidopsis thaliana & 1 & 6 & 48.892 & 445 \\
\hline 561 & SCAGLB1070D03.g & morphogenesis & & 1 & 10 & 40.52 & 359 \\
\hline 562 & SCCCRZ2C04B02.g & N metabolism & & 1 & 3 & 70.132 & 637 \\
\hline 563 & SCRLAM1013H01.g & $\mathrm{N}$-carbamoylputrescine amidase OS & Oryza sativa subsp. japonica & 2 & 3 & 46.552 & 407 \\
\hline 564 & SCACLR1057E10.g & $\begin{array}{l}\text { NADH dehydrogenase [ubiquinone] } 1 \text { beta subcomplex } \\
\text { subunit } 7\end{array}$ & & 1 & 12 & 36.207 & 334 \\
\hline 565 & SCQGLR1085G12.g & $\begin{array}{l}\text { NADH-ubiquinone oxidoreductase } 24 \mathrm{kDa} \text { subunit, } \\
\text { mitochondrial OS }\end{array}$ & Arabidopsis thaliana & 1 & 12 & 59.672 & 532 \\
\hline 566 & SCCCCL3120A08.b & NADP-dependent D-sorbitol-6-phosphate dehydrogenase & & 1 & 6 & 111.86 & 978 \\
\hline 567 & SCEPCL6019E04.g & NADP-dependent malic enzyme OS & Populus trichocarpa & 2 & 7 & 18.42 & 169 \\
\hline 568 & SCCCLR1048A08.g & NADP-dependent malic enzyme, chloroplastic OS & Oryza sativa subsp. japonica & 2 & 2 & 60.669 & 570 \\
\hline 569 & SCCCCL3001E04.b & NADP-dependent malic enzyme, chloroplastic OS & Zea mays & 1 & 10 & 57.917 & 510 \\
\hline 570 & SCJFRZ1007F04.g & NADPH-ferrihemoprotein reductase & & 1 & 3 & 52.431 & 487 \\
\hline 571 & SCBGLR1047D05.g & $\begin{array}{l}\text { Nascent polypeptide-associated complex subunit alpha-like } \\
\text { protein 1; }\end{array}$ & & 2 & 9 & 67.152 & 612 \\
\hline 572 & SCCCRZ1001E04.g & $\begin{array}{l}\text { Nascent polypeptide-associated complex subunit alpha-like } \\
\text { protein } 3\end{array}$ & & 3 & 18 & 59.164 & 528 \\
\hline 573 & SCUTLR1037C05.g & Nectarin-1; Superoxide dismutase [Mn]; & & 1 & 2 & 93.789 & 839 \\
\hline 574 & SCVPRZ2036E02.g & Nectarin-1; Superoxide dismutase [Mn]; & & 1 & 3 & 13.163 & 119 \\
\hline
\end{tabular}


Continuaçao Anexo 2.

\begin{tabular}{|c|c|c|c|c|c|c|c|}
\hline 575 & SCEQRT1030F10.g & $\begin{array}{l}\text { Nicotinamide mononucleotide adenylyltransferase 1; NMN } \\
\text { adenylyltransferase } 1\end{array}$ & & 1 & 7 & 29.983 & 277 \\
\hline 576 & SCCCLB1001H03.g & NIT2 nitrilase & & 1 & 3 & 46.976 & 431 \\
\hline 577 & SCQGLR1085E12.g & Nitrile-specifier protein 5 OS & Arabidopsis thaliana & 1 & 2 & 77.055 & 687 \\
\hline 578 & SCQSAM2047D12.g & Nodulation receptor kinase OS & Medicago truncatula & 1 & 10 & 36.516 & 347 \\
\hline 579 & SCQGHR1014E03.g & Nodulin-like protein & & 1 & 3 & 96.738 & 877 \\
\hline 580 & SCACLR2029H09.g & Non-specific lipid-transfer protein-like protein At2g13820 & Arabidopsis thaliana & 1 & 3 & 26.832 & 247 \\
\hline 581 & SCCCCL3001E03.b & Non-specific lipid-transfer protein-like protein At2g13820 & Arabidopsis thaliana & 1 & 2 & 48.366 & 449 \\
\hline 582 & SCEQSD1074D10.g & Non-specific lipid-transfer protein-like protein At5g64080 & Arabidopsis thaliana & 1 & 2 & 28.794 & 265 \\
\hline 583 & SCCCLR2001E08.g & Non-symbiotic hemoglobin; Hbt; ZEAmp GLB1 & & 2 & 4 & 26.697 & 237 \\
\hline 584 & SCAGRT2042G05.g & NPL4-like protein & & 3 & 9 & 41.943 & 392 \\
\hline 585 & SCCCCL2001A02.b & Nuclear migration protein nudC OS & Gallus gallus & 1 & 1 & 56.243 & 490 \\
\hline 586 & SCEQLB1065E01.g & Nuclear migration protein nudC & & 2 & 10 & 67.046 & 618 \\
\hline 587 & SCCCCL4002F10.g & nuclear mRNA splicing, via spliceosome & & 1 & 3 & 44.318 & 423 \\
\hline 588 & SCEPLB1044C02.g & nuclear mRNA splicing, via spliceosome & & 2 & 3 & 47.684 & 432 \\
\hline 589 & SCCCLR1070G02.g & Nuclear transport factor $2 \mathrm{OS}$ & Oryza sativa subsp. japonica & 1 & 10 & 68.003 & 615 \\
\hline 590 & SCJLLR1033D04.g & Nucleolar GTP-binding protein 2 & & 2 & 10 & 24.24 & 219 \\
\hline 591 & SCQGAM2030C12.g & Nucleoside diphosphate kinase 1 OS & Saccharum officinarum & 2 & 1 & 13.326 & 125 \\
\hline 592 & SCBGHR1061C01.g & Nucleoside diphosphate kinase IV, & & 2 & 2 & 21.723 & 205 \\
\hline 593 & SCCCRZ1C01H06.g & Nucleoside-triphosphatase OS & Pisum sativum & 1 & 3 & 40.372 & 363 \\
\hline 594 & SCJFRZ2014F02.g & Nucleoside-triphosphatase OS & Pisum sativum & 5 & 11 & 52.849 & 463 \\
\hline 595 & SCQSLR1018E09.g & Nucleosome assembly protein 1-like 1-A OS & Xenopus laevis & 2 & 2 & 34.908 & 336 \\
\hline 596 & SCEPLR1030F01.g & Nucleosome assembly protein 1-like 1 & & 2 & 11 & 38.925 & 358 \\
\hline 597 & SCCCLR2004A05.g & nucleosome assembly & & 1 & 12 & 85.163 & 770 \\
\hline 598 & SCACLR1127E10.g & Nucleotide metabolism & & 1 & 4 & 103.06 & 930 \\
\hline 599 & SCBFLR1083E03.g & Nucleotide metabolism & & 1 & 2 & 46.399 & 417 \\
\hline 600 & SCBGLR1120D04.g & Nucleotide metabolism & & 2 & 4 & 65.85 & 603 \\
\hline 601 & SCJFRZ2027B03.g & Nucleotide metabolism & & 1 & 11 & 55.16 & 487 \\
\hline 602 & SCRLLR1109F10.g & Nucleotide metabolism & & 2 & 2 & 26.393 & 239 \\
\hline 603 & SCJFRT1061G09.g & Nucleotide pyrophosphatase/phosphodiesterase & & 1 & 5 & 26.645 & 250 \\
\hline 604 & SCQGAM2026C05.g & Nudix hydrolase 3 OS & Arabidopsis thaliana & 1 & 12 & 34.339 & 302 \\
\hline 605 & SCEQRT1029E10.g & O-methyltransferase ZRP4 (OMT) & & 2 & 7 & 66.7 & 584 \\
\hline 606 & SCEQRT1027F02.g & O-methyltransferase ZRP4 OS & Zea mays & 1 & 1 & 15.996 & 139 \\
\hline 607 & SCEPCL6020A07.g & Obg-like ATPase 1; GTP-binding protein 9 & & 5 & 22 & 83.022 & 767 \\
\hline 608 & SCEZRZ1014C04.g & Osmotin-like protein OS & Solanum lycopersicum & 2 & 3 & 29.933 & 286 \\
\hline 609 & SCUTLR1037F02.g & Osmotin-like protein OS & Solanum lycopersicum & 2 & 9 & 36.424 & 346 \\
\hline 610 & SCCCLR1024G02.g & Oxysterol-binding protein & & 1 & 14 & 35.437 & 326 \\
\hline 611 & SCVPRT2075D04.g & Patatin-2-Kuras 1 OS & Solanum lycopersicum & 2 & 2 & 68.771 & 640 \\
\hline 612 & SCJFRT1009B01.g & patatin-like protein & & 2 & 18 & 71.417 & 675 \\
\hline 613 & SCJFRT1058C05.g & Patellin-5 OS & Arabidopsis thaliana & 1 & 5 & 21.786 & 191 \\
\hline 614 & SCCCRZ2002C11.g & Patellin-5 & & 1 & 4 & 36.532 & 352 \\
\hline 615 & SCQSRT1036D03.g & Pathogenesis-related protein 1 OS & Asparagus officinalis & 1 & 2 & 14.761 & 134 \\
\hline 616 & SCEZLB1010C02.g & Pathogenesis-related protein PRB1-3 OS & Hordeum vulgare & 4 & 10 & 37.116 & 350 \\
\hline 617 & SCCCRT3003E05.g & Pathogenesis-related protein PRMS OS & Zea mays & 1 & 2 & 64.211 & 595 \\
\hline 618 & SCCCLR1066G06.g & Pentose and Glucuronate interconversions & & 1 & 22 & 66.132 & 630 \\
\hline 619 & SCEQRT1030G05.g & Pentose phosphate pathway & & 1 & 2 & 23.671 & 225 \\
\hline 620 & SCJFRT1008E10.g & Pentose phosphate pathway & & 1 & 2 & 43.36 & 390 \\
\hline 621 & SCUTLR1037G10.g & Pentose phosphate pathway & & 7 & 4 & 16.418 & 157 \\
\hline 622 & SCCCLR2001G06.g & Peptidyl-prolyl cis-trans isomerase OS & Zea mays & 1 & 3 & 28.499 & 261 \\
\hline 623 & SCCCRZ2002A08.g & Peptidyl-prolyl cis-trans isomerase OS & Zea mays & 1 & 3 & 24.15 & 231 \\
\hline 624 & SCCCLR1C01H02.g & Peptidyl-prolyl cis-trans isomerase TLP20 & & 1 & 16 & 44.386 & 403 \\
\hline 625 & SCEQLB1067H09.g & Peptidylprolyl isomerase (EC 5.2.1.8) & & 1 & 4 & 30.323 & 283 \\
\hline 626 & SCCCLB1022G03.g & Periodic tryptophan protein 1 homolog & & 2 & 21 & 42.129 & 400 \\
\hline 627 & SCAGRT3049F04.g & peroxidase & & 2 & 11 & 67.632 & 619 \\
\hline 628 & SCBFLR1083H12.g & peroxidase & & 2 & 1 & 41.363 & 375 \\
\hline 629 & SCBFRZ2017C11.g & peroxidase & & 1 & 2 & 28.543 & 256 \\
\hline 630 & SCBGHR1058E08.g & peroxidase & & 3 & 10 & 46.818 & 427 \\
\hline 631 & SCBGRT3013B02.g & peroxidase & & 1 & 3 & 46.121 & 412 \\
\hline 632 & SCCCAD1001C08.g & peroxidase & & 1 & 11 & 59.986 & 546 \\
\hline 633 & SCCCCL2001D02.b & peroxidase & & 1 & 2 & 35.501 & 320 \\
\hline 634 & SCCCCL3002E11.b & peroxidase & & 1 & 3 & 52.656 & 472 \\
\hline 635 & SCCCCL3002F08.b & peroxidase & & 1 & 2 & 65.142 & 592 \\
\hline 636 & SCCCCL3003B02.b & peroxidase & & 2 & 14 & 83.663 & 760 \\
\hline 637 & SCCCCL4008H04.g & peroxidase & & 2 & 4 & 51.295 & 463 \\
\hline 638 & SCCCCL4012A01.g & peroxidase & & 1 & 2 & 17.803 & 171 \\
\hline 639 & SCCCCL7037A10.g & peroxidase & & 5 & 3 & 28.288 & 251 \\
\hline 640 & SCCCCL7C05F08.g & peroxidase & & 2 & 1 & 31.252 & 298 \\
\hline 641 & SCCCLB1004B09.g & peroxidase & & 1 & 10 & 22.908 & 217 \\
\hline 642 & SCCCLR1C05G08.g & peroxidase & & 1 & 2 & 16.147 & 153 \\
\hline 643 & SCCCRT1001G12.g & peroxidase & & 1 & 2 & 28.324 & 253 \\
\hline 644 & SCCCST3005E08.g & peroxidase & & 1 & 2 & 37.976 & 342 \\
\hline 645 & SCEPAM2056G07.g & peroxidase & & 1 & 1 & 28.3 & 256 \\
\hline 646 & SCEPRZ1011A06.g & peroxidase & & 1 & 1 & 23.158 & 205 \\
\hline 647 & SCEQRT1024D03.g & peroxidase & & 2 & 3 & 27.702 & 243 \\
\hline 648 & SCEQRT1024F02.g & peroxidase & & 2 & 1 & 15.024 & 133 \\
\hline 649 & SCEQRT1026F09.g & peroxidase & & 1 & 2 & 42.714 & 390 \\
\hline 650 & SCEQRT1028D12.g & peroxidase & & 1 & 2 & 24.032 & 238 \\
\hline 651 & SCEQRT1028H09.g & peroxidase & & 2 & 2 & 11.174 & 113 \\
\hline 652 & SCEQRT2030A04.g & peroxidase & & 2 & 1 & 11.044 & 107 \\
\hline 653 & SCEZRT2019F10.g & peroxidase & & 2 & 2 & 26.41 & 239 \\
\hline 654 & SCJFLR1035D02.g & peroxidase & & 1 & 6 & 16.226 & 152 \\
\hline 655 & \begin{tabular}{|l|} 
SCJFLR1035D05.g \\
\end{tabular} & peroxidase & & 3 & 2 & 32.375 & 280 \\
\hline 656 & SCJFRZ2013F04.g & peroxidase & & 2 & 7 & 65.095 & 600 \\
\hline 657 & SCRFRZ3054A09.g & peroxidase & & 1 & 6 & 41.653 & 383 \\
\hline 658 & SCJLLR1107D08.g & peroxidase & & 1 & 1 & 13.819 & 137 \\
\hline
\end{tabular}


Continuaçao Anexo 2.

\begin{tabular}{|c|c|c|c|c|c|c|c|}
\hline 659 & SCRLAD1042E05.g & peroxidase & & 2 & 7 & 57.37 & 512 \\
\hline 660 & SCRURT3064C05.g & peroxidase & & 1 & 2 & 55.811 & 488 \\
\hline 661 & SCSBRZ2021C03.g & peroxidase & & 1 & 1 & 62.129 & 571 \\
\hline 662 & SCSFCL6068C11.g & peroxidase & & 1 & 6 & 41.092 & 364 \\
\hline 663 & SCSGRT2062D07.g & peroxidase & & 2 & 4 & 61.561 & 532 \\
\hline 664 & SCSGRT2063H01.g & peroxidase & & 2 & 3 & 38.95 & 352 \\
\hline 665 & SCUTHR1063E12.g & peroxidase & & 1 & 5 & 67.884 & 616 \\
\hline 666 & SCVPLB1020D03.g & peroxidase & & 1 & 1 & 15.461 & 147 \\
\hline 667 & SCVPRZ2035F03.g & peroxidase & & 2 & 2 & 28.437 & 279 \\
\hline 668 & SCEPRZ1009H12.g & $\begin{array}{l}\text { Peroxiredoxin- } 2 \mathrm{~F} \text {, mitochondrial; Peroxiredoxin IIF; } \\
\text { Thioredoxin reductase } 2 \mathrm{~F} \text {; }\end{array}$ & & 1 & 2 & 31.779 & 290 \\
\hline 669 & SCCCLR1048D07.g & phenylalanine ammonia-lyase(PAL) & & 1 & 4 & 51.343 & 462 \\
\hline 670 & SCJFLR1017B11.g & phenylalanine ammonia-lyase(PAL) & & 1 & 6 & 49.306 & 452 \\
\hline 671 & SCJLRT1013C01.g & phenylalanine ammonia-lyase(PAL) & & 1 & 4 & 76.327 & 675 \\
\hline 672 & SCMCRT2105F08.g & Phosphate carrier protein, mitochondrial; & & 1 & 3 & 26.993 & 244 \\
\hline 673 & SCSFRT2072C08.g & Phosphatidylglycerol/phosphatidylinositol transfer protein & Aspergillus oryzae & 1 & 3 & 33.315 & 301 \\
\hline 674 & SCCCCL3001F10.b & Phosphoenolpyruvate carboxylase 1 & & 1 & 10 & 29.51 & 261 \\
\hline 675 & SCJLST1025D02.g & Phosphoglycerate kinase, cytosolic OS & Triticum aestivum & 1 & 1 & 50.56 & 463 \\
\hline 676 & SCAGLR1043E06.g & Phospholipase D alpha 1 OS & Zea mays & 2 & 2 & 33.034 & 325 \\
\hline 677 & SCQSLR1040D12.g & Phytochrome & & 2 & 2 & 8.9607 & 83 \\
\hline 678 & SCVPRZ2040D09.g & $\begin{array}{l}\text { Plant invertase/pectin methylesterase inhibitor or } \\
\text { Pectinesterase }\end{array}$ & & 2 & 4 & 51.58 & 465 \\
\hline 679 & SCQSRT1035E09.g & Pleckstrin homology domain-containing family A member & & 1 & 7 & 38.105 & 355 \\
\hline 680 & SCBGLR1023H10.g & Polyadenylate-binding protein 2 OS & Arabidopsis thaliana & 1 & 4 & 18.521 & 172 \\
\hline 681 & SCBFRT1067F03.g & Polyamine oxidase OS & Zea mays & 3 & 4 & 89.053 & 790 \\
\hline 682 & SCQGSB1143H12.g & Polyamine oxidase OS & Zea mays & 1 & 1 & 48.411 & 439 \\
\hline 683 & SCJFRZ1007G02.g & Polyamine oxidase; & & 1 & 4 & 72.728 & 651 \\
\hline 684 & SCVPLR2019B03.g & Polygalacturonase inhibitor 1 OS & Oryza sativa subsp. japonica & 3 & 4 & 26.591 & 252 \\
\hline 685 & SCCCFL4119D10.g & Polygalacturonase QRT3 OS & Arabidopsis thaliana & 2 & 2 & 29.515 & 247 \\
\hline 686 & SCEPAM1051D07.g & Polyphenol oxidase, chloroplastic OS & Malus domestica & 2 & 6 & 54.576 & 480 \\
\hline 687 & SCEZLB1007D07.g & Polyphenol oxidase, chloroplastic OS & Malus domestica & 2 & 2 & 20.076 & 178 \\
\hline 688 & SCEZRZ1016D05.g & Polyphenol oxidase, chloroplastic OS & Malus domestica & 1 & 2 & 76.292 & 713 \\
\hline 689 & SCVPLB1016F07.g & Polyphenol oxidase, chloroplastic OS & Malus domestica & 1 & 4 & 41.56 & 380 \\
\hline 690 & SCSGLR1045A10.g & Polyphenol oxidase, chloroplastic & & 2 & 10 & 68.376 & 627 \\
\hline 691 & SCCCLR1C07C07.g & POT family (PTR2) & & 1 & 2 & 52.677 & 487 \\
\hline 692 & SCCCLR1070C10.g & PP2A inhibitor & & 1 & 3 & 54.039 & 477 \\
\hline 693 & SCCCLR1080G12.g & Pre-mRNA-processing factor 19 homolog 2 OS & Arabidopsis thaliana & 1 & 3 & 19.795 & 199 \\
\hline 694 & SCCCLR1C07G02.g & PREDICTED: ras-related protein RABH1b-like & Brachypodium distachyon & 2 & 1 & 21.407 & 199 \\
\hline 695 & SCMCRT2102D05.g & Prefoldin subunit 6 (Protein Ke2) & & 1 & 3 & 34.435 & 306 \\
\hline 696 & SCUTLR1037C03.g & Proactivator polypeptide; Saposin-A; Protein A & & 1 & 2 & 15.661 & 144 \\
\hline 697 & SCCCLR1048G11.g & Probable $26 \mathrm{~S}$ proteasome non-ATPase regulatory subunit 3 & & 1 & 3 & 48.558 & 444 \\
\hline 698 & SCBGLR1114F09.g & Probable ADP-ribosylation factor GTPase-activating protein & & 1 & 11 & 62.86 & 581 \\
\hline 699 & SCJFRZ1006B05.g & Probable aldehyde dehydrogenase & & 1 & 10 & 29.532 & 256 \\
\hline 700 & SCMCCL6059G10.g & Probable aldehyde oxidase 2 OS & Oryza sativa subsp. japonica & 2 & 8 & 42.443 & 387 \\
\hline 701 & SCJLRT1020A08.g & Probable alpha-glucosidase Os06g0675700 OS & Oryza sativa subsp. japonica & 1 & 2 & 32.77 & 294 \\
\hline 702 & SCSGCL6072E02.g & Probable alpha-glucosidase Os06g0675700 OS & Oryza sativa subsp. japonica & 1 & 8 & 57.348 & 523 \\
\hline 703 & SCEQRT2098D07.g & Probable ATP synthase $24 \mathrm{kDa}$ subunit, mitochondrial OS & Arabidopsis thaliana & 2 & 1 & 24.382 & 221 \\
\hline 704 & SCSGLR1045G11.g & $\begin{array}{l}\text { Probable calcium-binding protein CML7 (Calmodulin-like } \\
\text { protein 7) }\end{array}$ & & 1 & 20 & 48.496 & 456 \\
\hline 705 & SCCCRT2002H05.g & Probable cytochrome $\mathrm{c}$ biosynthesis protein & & 1 & 6 & 39.35 & 347 \\
\hline 706 & SCCCSD1002H05.g & Probable disease resistance protein At5g66910 OS & Arabidopsis thaliana & 3 & 7 & 111.96 & 1022 \\
\hline 707 & SCCCCL3005E06.b & Probable fructose-bisphosphate aldolase 3, & Arabidopsis thaliana & 2 & 4 & 23.749 & 225 \\
\hline 708 & SCCCCL4011D07.g & Probable glutathione S-transferase GSTU1 & & 1 & 3 & 28.756 & 274 \\
\hline 709 & SCCCCL3120D03.g & Probable glutathione S-transferase; Auxin-induced & & 2 & 2 & 52.506 & 487 \\
\hline 710 & SCEPLR1051D01.g & Probable glycerophosphoryl diester phosphodiesterase 1 & Arabidopsis thaliana & 1 & 3 & 25.33 & 230 \\
\hline 711 & SCJFRT1010B06.g & Probable inactive purple acid phosphatase 1 OS & Arabidopsis thaliana & 1 & 29 & 83.405 & 749 \\
\hline 712 & SCEZRZ1014E01.g & Probable inactive purple acid phosphatase 27 OS & Arabidopsis thaliana & 2 & 9 & 34.718 & 315 \\
\hline 713 & SCVPCL6044H09.g & Probable methionine aminopeptidase 1 (EC 3.4.11.18) & & 1 & 5 & 36.029 & 336 \\
\hline 714 & SCJLLR1054C07.g & Probable mitochondrial-processing peptidase subunit beta & Arabidopsis thaliana & 1 & 2 & 44.653 & 399 \\
\hline 715 & SCJFLR1074A06.g & Probable nucleoredoxin 1-1 OS & Oryza sativa subsp. japonica & 1 & 29 & 78.519 & 698 \\
\hline 716 & SCVPLR1028G12.g & Probable nucleoredoxin 1-1 OS & Oryza sativa subsp. japonica & 1 & 15 & 52.672 & 480 \\
\hline 717 & SCEZLR1031F07.g & Probable peptidyl-prolyl cis-trans isomerase; & & 2 & 2 & 35.001 & 335 \\
\hline 718 & SCCCRZ2C01F01.g & $\begin{array}{l}\text { Probable phospholipid hydroperoxide glutathione } \\
\text { peroxidase } 6 \text {, mitochondrial OS }\end{array}$ & Arabidopsis thaliana & 2 & 9 & 45.592 & 421 \\
\hline 719 & SCBGLR1023B11.g & Probable polyamine oxidase 4 & & 1 & 8 & 52.536 & 478 \\
\hline 720 & SCSBSD2029A05.g & Probable prefoldin subunit 3 OS & Arabidopsis thaliana & 3 & 10 & 66.542 & 594 \\
\hline 721 & SCCCLR1C01A02.g & Probable protein disulfide-isomerase A6 OS & Medicago sativa & 1 & 1 & 27.569 & 272 \\
\hline 722 & SCCCLR1077B12.g & Probable protein disulfide-isomerase A6; P5; & & 1 & 1 & 25.026 & 239 \\
\hline 723 & SCAGRT2039C06.g & Probable RNA 3-terminal phosphate cyclase-like protein & Arabidopsis thaliana & 1 & 2 & 13.58 & 126 \\
\hline 724 & SCEPLB1043F04.g & Probable small nuclear ribonucleoprotein F; & & 2 & 2 & 41.591 & 397 \\
\hline 725 & SCCCLR1076F06.g & Probable small nuclear ribonucleoprotein G; & & 3 & 4 & 35.173 & 317 \\
\hline 726 & SCSGFL1081H08.g & Probable succinyl-CoA ligase [GDP-forming] subunit alpha & Oryza sativa subsp. japonica & 1 & 13 & 41.49 & 376 \\
\hline 727 & SCBFST3136C07.g & Profilin-A & & 2 & 2 & 32.103 & 305 \\
\hline 728 & SCEQRT1033H09.g & Prohibitin-2 & & 2 & 4 & 23.361 & 228 \\
\hline 729 & SCCCCL4009H11.g & prohibitin2 & Zea mays & 1 & 21 & 75.304 & 678 \\
\hline 730 & SCCCLB1023A12.g & Proline iminopeptidase (EC 3.4.11.5) & & 1 & 1 & 17.421 & 170 \\
\hline 731 & SCBFRZ3006A04.g & Protease 2 OS & Escherichia coli & 1 & 4 & 39.119 & 350 \\
\hline 732 & SCJLRT1018H05.g & Protease 2; Protease II; Oligopeptidase B & & 1 & 1 & 18.606 & 177 \\
\hline 733 & SCVPRT2080B07.g & Protease inhibitor & & 1 & 3 & 38.057 & 379 \\
\hline 734 & SCCCCL3140C10.g & Protease inhibitors & & 1 & 2 & 41.964 & 390 \\
\hline 735 & SCJLRT2051G07.g & Protease inhibitors & & 2 & 3 & 12.211 & 116 \\
\hline 736 & SCVPRT2073B04.g & Protease inhibitors & & 2 & 11 & 53.511 & 477 \\
\hline 737 & SCQSLR1018D04.g & Proteasome component & & 1 & 5 & 57.908 & 542 \\
\hline
\end{tabular}


Continuaçao Anexo 2.

\begin{tabular}{|c|c|c|c|c|c|c|c|}
\hline 738 & SCEPLB1041G09.g & Proteasome subunit alpha type-1 & & 1 & 9 & 46.048 & 429 \\
\hline 739 & SCSBAM1085E11.g & Proteasome subunit alpha type- 3 OS & Oryza sativa subsp. japonica & 1 & 4 & 26.555 & 256 \\
\hline 740 & SCSGLR1045C03.g & Proteasome subunit alpha type- 3 OS & Oryza sativa subsp. japonica & 1 & 3 & 18.282 & 167 \\
\hline 741 & SCVPLR2019H10.g & Proteasome subunit alpha type-3 OS & Oryza sativa subsp. japonica & 2 & 7 & 52.853 & 483 \\
\hline 742 & SCEQHR1080E08.g & Proteasome subunit alpha type-4-2 OS & Oryza sativa subsp. japonica & 1 & 3 & 34.032 & 306 \\
\hline 743 & SCAGLR2026H05.g & Proteasome subunit alpha type- 5 OS & Oryza sativa subsp. japonica & 1 & 1 & 73.126 & 657 \\
\hline 744 & SCCCLR1001B04.g & Proteasome subunit alpha type- 6 & & 1 & 11 & 40.533 & 355 \\
\hline 745 & SCJFRZ2010D05.g & Proteasome subunit alpha type-7-A & & 1 & 7 & 29.264 & 264 \\
\hline 746 & SCACLR2007D12.g & Proteasome subunit beta type-1 OS & Oryza sativa subsp. japonica & 1 & 2 & 60.845 & 545 \\
\hline 747 & SCBGLR1002D03.g & Proteasome subunit beta type-1 OS & Oryza sativa subsp. japonica & 2 & 3 & 63.972 & 572 \\
\hline 748 & SCCCLR1048G12.g & Proteasome subunit beta type- 2 ; & & 1 & 4 & 39.275 & 386 \\
\hline 749 & SCCCLR1001C09.g & Proteasome subunit beta type- 3 ; & & 3 & 3 & 27.159 & 249 \\
\hline 750 & SCCCCL3120F07.g & Proteasome subunit beta type- 4 & & 2 & 3 & 41.125 & 380 \\
\hline 751 & SCCCLR1C02B03.g & Proteasome subunit beta type-5-A OS & Arabidopsis thaliana & 1 & 3 & 102.74 & 923 \\
\hline 752 & SCCCLR1068D08.g & Proteasome subunit beta type-7-A OS & Arabidopsis thaliana & 1 & 3 & 96.999 & 880 \\
\hline 753 & SCCCLR2001A02.g & Protein CutA 1, chloroplastic OS & Oryza sativa subsp. japonica & 3 & 6 & 29.521 & 282 \\
\hline 754 & SCJFRZ2009A01.g & Protein DEHYDRATION-INDUCED 19 homolog 2 OS & Oryza sativa subsp. japonica & 1 & 4 & 42.6 & 380 \\
\hline 755 & SCCCLR1077G10.g & Protein disulfide isomerase A6 precursor (EC 5.3.4.1) & & 1 & 2 & 37.488 & 347 \\
\hline 756 & SCCCLR1048G04.g & Protein disulfide-isomerase OS & Zea mays & 3 & 3 & 21.719 & 203 \\
\hline 757 & SCQSST1040D05.g & Protein FAM136A & & 1 & 2 & 48.118 & 427 \\
\hline 758 & SCJFRZ3C01D12.g & Protein grpE; HSP-70 cofactor & & 1 & 5 & 28.865 & 259 \\
\hline 759 & SCJFLR1013F08.g & Protein IN2-1 & & 2 & 2 & 22.579 & 215 \\
\hline 760 & SCJLRZ1027G11.g & Protein IN2-1 & & 1 & 3 & 33.334 & 293 \\
\hline 761 & SCQSAM2100C08.g & Protein mago nashi homolog OS & Oryza sativa subsp. japonica & 1 & 1 & 35.869 & 321 \\
\hline 762 & SCCCLR2001B09.g & Protein MEMO1 (Mediator of ErbB2-driven cell motility 1) & & 2 & 1 & 8.49 & 79 \\
\hline 763 & SCCCST3006H10.g & Protein RER1A (AtRER1A) & & 1 & 9 & 39.472 & 376 \\
\hline 764 & SCCCLR2001H02.g & Protein TOPLESS & & 2 & 4 & 69.631 & 645 \\
\hline 765 & SCJFRT2057H05.g & Protein transport protein Sec16B OS & Oryctolagus cuniculus & 1 & 3 & 39.2 & 351 \\
\hline 766 & SCUTLR1058A05.g & Protein transport protein Sec24-like CEF OS & Arabidopsis thaliana & 1 & 2 & 72.981 & 667 \\
\hline 767 & SCCCCL4015D05.g & Protein transport protein sec31 & & 1 & 2 & 18.598 & 174 \\
\hline 768 & SCCCCL3140C07.g & Protein VERNALIZATION INSENSITIVE 3 & & 1 & 3 & 23.783 & 217 \\
\hline 769 & SCJFRZ2015A08.g & Protein VERNALIZATION INSENSITIVE 3 & & 1 & 2 & 38.724 & 352 \\
\hline 770 & SCJFRT2055H11.g & Puromycin-sensitive aminopeptidase; PSA & & 1 & 2 & 27.838 & 260 \\
\hline 771 & SCVPRZ2043H01.g & Purple acid phosphatase 2 OS & Ipomoea batatas GN & 1 & 2 & 52.967 & 482 \\
\hline 772 & SCCCLR1066F03.g & Purple acid phosphatase; Zinc(II) purple acid phosphatase & & 1 & 2 & 73.298 & 645 \\
\hline 773 & SCEPRZ1010G06.g & Putative 6-phosphogluconolactonase (Fragment) & & 2 & 1 & 19.66 & 188 \\
\hline 774 & SCQGLB1038F04.g & Putative acetolactate synthase & & 3 & 2 & 33.174 & 324 \\
\hline 775 & SCQSLB1052F09.g & putative acetyl transferase & & 2 & 5 & 37.251 & 332 \\
\hline 776 & SCCCCL3001A05.g & Putative aconitate hydratase, cytoplasmic OS & Oryza sativa subsp. japonica & 2 & 13 & 80.221 & 698 \\
\hline 777 & SCCCLR1065F02.g & Putative aconitate hydratase, cytoplasmic OS & Oryza sativa subsp. japonica & 1 & 2 & 27.836 & 246 \\
\hline 778 & SCQSRT2031F11.g & Putative aldehyde oxidase-like protein OS & Oryza sativa subsp. japonica & 1 & 5 & 30.72 & 285 \\
\hline 779 & SCJFST1012D03.g & Putative beta-mannosidase & & 2 & 10 & 66.362 & 594 \\
\hline 780 & SCAGLR1064E01.g & putative carboxymethylenebutenolidase & & 2 & 3 & 33.84 & 310 \\
\hline 781 & SCCCLR1024F02.g & Putative DNA repair protein RAD23-4 & & 1 & 12 & 68.921 & 625 \\
\hline 782 & SCBGHR1061E10.g & putative extensin & & 1 & 2 & 19.355 & 172 \\
\hline 783 & SCBFLR1026E04.g & Putative glucose-6-phosphate 1-epimerase OS & Cenchrus ciliaris & 2 & 1 & 18.984 & 179 \\
\hline 784 & SCJFRT1058A12.g & Putative peroxisomal-coenzyme $\mathrm{A}$ synthetase OS & Schizosaccharomyces pombe & 1 & 32 & 73.301 & 664 \\
\hline 785 & SCCCLR1048C11.g & Putative protein TPRXL & & 1 & 32 & 107.31 & 956 \\
\hline 786 & SCCCCL3001E09.b & putative SnRK1-interacting protein 1 & & 2 & 4 & 21.341 & 197 \\
\hline 787 & SCRFLR2034C11.g & Putative steroid-binding protein 2; AtMP2 & & 1 & 1 & 15.847 & 144 \\
\hline 788 & SCJFRZ2031H09.g & Putative steroid-binding protein 3; AtMP3 & & 1 & 1 & 35.399 & 338 \\
\hline 789 & SCCCRT1004D01.g & Putative wall-associated protein kinase & & 3 & 27 & 84.607 & 782 \\
\hline 790 & SCCCRZ2C03E07.g & $\begin{array}{l}\text { Pyrophosphate-energized vacuolar membrane proton } \\
\text { pump }\end{array}$ & & 1 & 2 & 45.22 & 408 \\
\hline 791 & SCCCCL4011D12.g & Pyruvate decarboxylase isozyme 2 OS & Oryza sativa subsp. indica & 2 & 4 & 72.626 & 637 \\
\hline 792 & SCCCCL1002D10.b & Pyruvate dehydrogenase E1 component subunit alpha-1, & Arabidopsis thaliana & 1 & 4 & 43.063 & 399 \\
\hline 793 & SCCCLR1065E04.g & Pyruvate dehydrogenase E1 component subunit beta OS & Staurastrum punctulatum & 1 & 3 & 37.502 & 334 \\
\hline 794 & SCJLRT1023A07.g & pyruvate dehydrogenase 2 & Zea mays & 1 & 2 & 37.489 & 350 \\
\hline 795 & SCEZLB1006G09.g & Pyruvate kinase, cytosolic isozyme OS & Nicotiana tabacum & 1 & 7 & 84.96 & 756 \\
\hline 796 & SCCCLR2C01A06.g & R-gene & & 1 & 3 & 51.932 & 462 \\
\hline 797 & SCCCRT2002D03.g & R-genes transduction & & 1 & 3 & 43.079 & 381 \\
\hline 798 & SCEPLB1043E09.g & Rab GDP dissociation inhibitor alpha (Rab GDI alpha) & & 1 & 2 & 26.375 & 239 \\
\hline 799 & SCCCLR1001G12.g & Rab GDP dissociation inhibitor alpha & Zea mays & 1 & 2 & 38.344 & 366 \\
\hline 800 & SCCCLR1075B02.g & Rab & & 2 & 2 & 25.881 & 263 \\
\hline 801 & SCCCRZ2002A07.g & Rab & & 3 & 3 & 21.648 & 196 \\
\hline 802 & SCEQLR1007G11.g & RAN GTPase-activating protein $2 \mathrm{OS}$ & Arabidopsis thaliana & 1 & 1 & 23.131 & 213 \\
\hline 803 & SCEQRT2028E03.g & Ran & & 2 & 4 & 67.562 & 628 \\
\hline 804 & SCQSRT2033A11.g & Ras GTPase-activating protein-binding protein 1 OS & Pongo abelii & 1 & 5 & 50.97 & 477 \\
\hline 805 & SCCCLR1C07D08.g & ras-related protein Rab7 & Zea mays & 1 & 2 & 25.546 & 243 \\
\hline 806 & SCSGRZ3062A12.g & Receptor Ser/Thr kinase-unclassified & & 1 & 2 & 29.854 & 281 \\
\hline 807 & SCCCLR1072H06.g & receptor Ser/Thr kinase & & 1 & 6 & 38.077 & 342 \\
\hline 808 & SCCCRZ1C01H05.g & receptor Ser/Thr kinase & & 1 & 2 & 18.719 & 179 \\
\hline 809 & SCVPAM2064B04.g & Receptor-like protein kinase FERONIA OS & Arabidopsis thaliana & 1 & 1 & 14.138 & 134 \\
\hline 810 & SCMCSB1116D02.g & Phosphoenolpyruvate carboxylase 2; Short & & 4 & 3 & 27.695 & 257 \\
\hline 811 & SCRUAD1061B04.g & RecName:Arginine/serine-rich protein 45 & & 2 & 10 & 64.88 & 574 \\
\hline 812 & SCEPLB1041F10.g & RecName:BAG family molecular chaperone regulator 7 & & 1 & 32 & 99.41 & 890 \\
\hline 813 & SCJFRT1060F07.g & RecName:Basic proline-rich protein & & 3 & 3 & 44.051 & 401 \\
\hline 814 & SCJLAM2093F08.g & RecName:Basic proline-rich protein & & 1 & 7 & 44.755 & 397 \\
\hline 815 & SCCCRZ2002D08.g & RecName:DNA ligase 1; AltName:DNA ligase I; & & 1 & 2 & 45.473 & 412 \\
\hline 816 & SCAGLR2011D03.g & RecName:Glycoprotein gp2; AltName:Glycoprotein X & & 1 & 3 & 88.801 & 810 \\
\hline 817 & SCCCLR2001A08.g & RecName:Glycoprotein gp2; AltName:Glycoprotein X & & 1 & 5 & 19.954 & 187 \\
\hline 818 & SCSGLR1084C03.g & RecName:Glycoprotein gp2; AltName:Glycoprotein X & & 1 & 3 & 30.989 & 280 \\
\hline 819 & SCUTLR2023H05.g & RecName:Glycoprotein gp2; AltName:Glycoprotein X & & 3 & 6 & 21.672 & 202 \\
\hline 820 & SCJFHR1032A01.g & RecName:Mediator of RNA polymerase II transcription & & 1 & 1 & 15.058 & 139 \\
\hline 821 & SCCCLR1065D07.g & RecName:Mucin-5AC; Short & & 1 & 3 & 21.571 & 194 \\
\hline
\end{tabular}


Continuaçao Anexo 2.

\begin{tabular}{|c|c|c|c|c|c|c|c|}
\hline 822 & SCCCLR1048C07.g & RecName:Outer envelope pore protein $16-3$, & & 1 & 1 & 19.121 & 175 \\
\hline 823 & SCRURT3061D09.g & RecName:Pre-mRNA-splicing factor cwc-22 & & 1 & 2 & 50.151 & 436 \\
\hline 824 & SCEQRT1026F05.g & RecName:Probable carboxylesterase 2 & & 1 & 2 & 38.303 & 338 \\
\hline 825 & SCSGLR1045C09.g & RecName:Probable RNA polymerase II transcription factor & & 1 & 2 & 41.248 & 370 \\
\hline 826 & SCJFRT2057H11.g & RecName:Putative lipid-transfer protein DIR1 & & 1 & 2 & 14.204 & 135 \\
\hline 827 & SCBGLR1118F05.g & RecName:Putative protein TPRXL & & 1 & 3 & 26.309 & 235 \\
\hline 828 & SCCCST3001E10.g & \begin{tabular}{|l|} 
RecName:Putative protein TPRXL \\
\end{tabular} & & 1 & 2 & 21.056 & 187 \\
\hline 829 & SCQSLB1052E10.g & RecName:Putative uncharacterized protein & & 3 & 3 & 24.145 & 233 \\
\hline 830 & SCEZLB1007D12.g & RecName:Rapid alkalinization factor; Short & & 1 & 2 & 35.443 & 324 \\
\hline 831 & SCJFRZ2014G08.g & RecName:Rapid alkalinization factor; Short & & 1 & 3 & 22.078 & 193 \\
\hline 832 & SCEQAM2038F09.g & RecName:Serine-rich adhesin for platelets; & & 1 & 2 & 22.662 & 222 \\
\hline 833 & SCCCCL4014C12.g & RecName:Serine/arginine repetitive matrix protein 1 & & 1 & 2 & 32.14 & 287 \\
\hline 834 & SCJFLR1074F10.g & RecName:Serine/arginine repetitive matrix protein 2; & & 1 & 1 & 21.912 & 203 \\
\hline 835 & SCEZRT3069B05.g & RecName:Serine/arginine repetitive matrix protein 2 & & 2 & 2 & 49.024 & 463 \\
\hline 836 & SCJFHR1031D08.g & RecName:Serine/arginine repetitive matrix protein 2 & & 1 & 4 & 68.384 & 626 \\
\hline 837 & SCSGLR1084A12.g & RecName:Serine/arginine repetitive matrix protein 2 & & 1 & 2 & 99.913 & 895 \\
\hline 838 & SCCCRZ2003B05.g & RecName:Translation initiation factor IF-2 & & 1 & 1 & 46.492 & 429 \\
\hline 839 & SCSFRT2069A03.g & RecName:Translation initiation factor IF-2 & & 1 & 2 & 13.799 & 130 \\
\hline 840 & SCCCCL3001H10.b & RecName:Translocon-associated protein subunit beta & & 1 & 2 & 93.965 & 854 \\
\hline 841 & SCSBFL4012F03.g & RecName:Uncharacterized protein C10orf95 & & 1 & 3 & 51.232 & 461 \\
\hline 842 & SCSFST1066G10.g & \begin{tabular}{|l|} 
RecName:Uncharacterized protein C10orf95 \\
\end{tabular} & & 1 & 2 & 49.818 & 454 \\
\hline 843 & SCCCLB1004F12.g & RecName:Uncharacterized protein LOC284861 & & 5 & 3 & 58.998 & 546 \\
\hline 844 & SCEQRT1028B12.g & RecName:Uncharacterized protein LOC284861 & & 1 & 11 & 82.138 & 748 \\
\hline 845 & SCEQRT2090E08.g & RecName:Uncharacterized protein LOC284861 & & 1 & 13 & 56.155 & 484 \\
\hline 846 & SCEQRT2091H09.g & RecName:Uncharacterized protein LOC284861 & & 1 & 4 & 16.6 & 160 \\
\hline 847 & SCEZLR1052E12.g & RecName:Uncharacterized protein LOC284861 & & 4 & 21 & 57.165 & 517 \\
\hline 848 & SCQGLR1019D06.g & RecName:Uncharacterized protein LOC284861 & & 1 & 3 & 93.505 & 834 \\
\hline 849 & SCCCLR2C01H04.g & RecName:UPF0317 protein KRH_21160 & & 1 & 3 & 54.354 & 478 \\
\hline 850 & SCCCCL3140C05.g & RecName:Vegetative cell wall protein gp1 & & 7 & 4 & 30.4 & 290 \\
\hline 851 & SCQSST3113G08.g & RecName:Vegetative cell wall protein gp1 & & 2 & 30 & 68.064 & 621 \\
\hline 852 & SCEQLB1064D04.g & RecName:Zinc finger protein ZAT1 & & 2 & 9 & 37.895 & 341 \\
\hline 853 & SCCCCL3140F04.g & regulation of DNA replication & & 23 & 7 & 16.257 & 151 \\
\hline 854 & SCBGLR1002A12.g & regulation of transcription, DNA-dependent & & 1 & 2 & 37.147 & 351 \\
\hline 855 & SCCCCL3001B04.b & regulation of transcription, DNA-dependent & & 1 & 2 & 44.362 & 400 \\
\hline 856 & SCCCCL3004H02.b & regulation of transcription, DNA-dependent & & 1 & 1 & 77.153 & 710 \\
\hline 857 & SCCCCL5003D05.g & regulation of transcription, DNA-dependent & & 1 & 4 & 40.684 & 354 \\
\hline 858 & SCCCLR1048A10.g & regulation of transcription, DNA-dependent & & 1 & 8 & 21.379 & 178 \\
\hline 859 & SCCCLR1066B09.g & regulation of transcription, DNA-dependent & & 2 & 3 & 78.636 & 765 \\
\hline 860 & SCCCLR2C03A06.g & regulation of transcription, DNA-dependent & & 4 & 4 & 20.231 & 179 \\
\hline 861 & SCCCRZ1004G10.g & regulation of transcription, DNA-dependent & & 1 & 2 & 31.382 & 281 \\
\hline 862 & SCQGLR1019B02.g & regulation of transcription, DNA-dependent & & 4 & 15 & 64.19 & 573 \\
\hline 863 & SCRULB1059F02.g & regulation of transcription, DNA-dependent & & 1 & 4 & 86.462 & 775 \\
\hline 864 & SCVPLR2019F03.g & regulation of transcription, DNA-dependent & & 1 & 6 & 32.996 & 298 \\
\hline 865 & SCBGST3105H08.g & Regulator of ribonuclease-like protein 2 OS & Arabidopsis thaliana & 1 & 4 & 20.598 & 190 \\
\hline 866 & SCQGLR1041A05.g & response to heat & & 1 & 3 & 20.935 & 194 \\
\hline 867 & SCCCLB1004D05.g & response to oxidative stress & & 1 & 5 & 19.461 & 182 \\
\hline 868 & SCCCLR1001E03.g & response to oxidative stress & & 1 & 7 & 21.168 & 197 \\
\hline 869 & SCEQRT2099G01.g & response to oxidative stress & & 1 & 3 & 75.921 & 686 \\
\hline 870 & SCAGRT2039E07.g & Reticuline oxidase-like protein OS & Arabidopsis thaliana & 1 & 1 & 11.775 & 109 \\
\hline 871 & SCAGLR1021B05.g & reversibly glycosylated polypeptide & & 1 & 2 & 19.054 & 188 \\
\hline 872 & SCBFFL5074C09.g & reversibly glycosylated polypeptide & & 1 & 1 & 33.418 & 287 \\
\hline 873 & SCRFLR1012F02.g & reversibly glycosylated polypeptide & & 2 & 3 & 19.425 & 171 \\
\hline 874 & SCBGRT1047G10.g & Rhicadhesin receptor; Germin-like protein; & & 1 & 1 & 29.746 & 272 \\
\hline 875 & SCEPRZ1009E05.g & Rho GTPase-activating protein 20 & & 1 & 6 & 43.488 & 387 \\
\hline 876 & SCMCRT2086F08.g & Ribonuclease 2; & & 2 & 3 & 16.546 & 153 \\
\hline 877 & SCUTRZ3070D05.g & Ribose-phosphate pyrophosphokinase 3 & & 1 & 1 & 38.418 & 358 \\
\hline 878 & SCCCLR1C04E09.g & Ribosomal protein L15 & & 1 & 2 & 57.676 & 523 \\
\hline 879 & SCBGFL5081F09.g & Ribosomal protein L25 (Fragment) & & 1 & 3 & 53.957 & 508 \\
\hline 880 & SCAGLR2033D11.g & Ribosomal protein L3 & & 1 & 10 & 41.695 & 377 \\
\hline 881 & SCJLLR1101C01.g & Ribosomal protein S7 & & 3 & 8 & 32.509 & 297 \\
\hline 882 & SCVPLR2005E09.g & Ribosomal protein S7 & & 1 & 8 & 44.414 & 392 \\
\hline 883 & SCCCRZ2001F06.g & ribosomal protein & & 1 & 1 & 31.014 & 281 \\
\hline 884 & SCCCLR2001B03.g & Ribosome biogenesis protein BRX1 homolog OS & Homo sapiens & 1 & 3 & 41.1 & 369 \\
\hline 885 & SCRLAM1008E06.g & Ribosome-binding protein 1; Ribosome receptor protein & & 4 & 19 & 103.17 & 936 \\
\hline 886 & SCEPAM1021C06.g & Ribosome-inactivating protein 9 OS & Zea mays & 2 & 7 & 27.267 & 265 \\
\hline 887 & SCRUFL1112F04.b & RNA stability & & 2 & 3 & 10.313 & 88 \\
\hline 888 & SCVPCL6038H06.g & RNA-binding protein Musashi homolog Rbp6 OS & Drosophila melanogaster & 1 & 3 & 50.334 & 459 \\
\hline 889 & SCCCCL4012A11.g & RSTK & & 2 & 2 & 26.263 & 237 \\
\hline 890 & SCCCLR2C02D03.g & RuBisCO large subunit-binding protein subunit alpha & Triticum aestivum & 3 & 7 & 108.87 & 996 \\
\hline 891 & SCCCRZ1004G05.g & RuBisCO large subunit-binding protein subunit beta & Pisum sativum & 2 & 7 & 31.891 & 287 \\
\hline 892 & SCUTLR1058B02.g & S-adenosylmethionine synthase 1 OS & Triticum monococcum & 1 & 3 & 25.367 & 235 \\
\hline 893 & SCJFRZ2028D05.g & S-formylglutathione hydrolase; AtSFGH; Esterase D & & 1 & 1 & 30.303 & 295 \\
\hline 894 & SCCCLR1079C11.g & Salt stress root protein RS1 OS & Oryza sativa subsp. japonica & 1 & 1 & 50.245 & 447 \\
\hline 895 & SCEQLR1050H09.g & Salt stress root protein RS1 OS & Oryza sativa subsp. japonica & 1 & 3 & 27.159 & 248 \\
\hline 896 & SCBGRT1053D07.g & Salutaridine reductase OS & Papaver bracteatum & 1 & 1 & 20.671 & 193 \\
\hline 897 & SCVPRZ2043E04.g & SBP (squamosa promoter binding protein) & & 1 & 3 & 35.736 & 337 \\
\hline 898 & SCCCRT1002E09.g & Serine carboxypeptidase 2 OS & Triticum aestivum & 1 & 6 & 40.497 & 362 \\
\hline 899 & SCEZLB1007G10.g & Serine carboxypeptidase 2 OS & Triticum aestivum & 1 & 3 & 27.451 & 253 \\
\hline 900 & SCJFRT1009C10.g & Serine carboxypeptidase II chains A and B (EC 3.4.16.6) & & 1 & 2 & 52.544 & 496 \\
\hline 901 & SCCCLR1024A12.g & Serine carboxypeptidase II-2 precursor (EC 3.4.16.6) & & 2 & 9 & 55.786 & 506 \\
\hline 902 & SCEZRZ3016H03.g & Serine carboxypeptidase II-3 OS & Hordeum vulgare & 2 & 10 & 39.144 & 364 \\
\hline 903 & SCCCRZ2C04H09.g & Serine carboxypeptidase-like 19 OS & Arabidopsis thaliana & 1 & 2 & 22.255 & 200 \\
\hline 904 & SCBFRZ2017A10.g & Serine carboxypeptidase-like OS & Oryza sativa subsp. japonica & 1 & 3 & 20.497 & 191 \\
\hline 905 & SCUTST3092B09.g & Serine/threonine-protein kinase SRPK1 OS & Mus musculus & 1 & 1 & 20.473 & 199 \\
\hline 906 & SCCCLR2003C11.g & Serine/threonine-protein phosphatase PP1 OS & Zea mays & 1 & 1 & 73.264 & 671 \\
\hline
\end{tabular}


Continuaçao Anexo 2.

\begin{tabular}{|c|c|c|c|c|c|c|c|}
\hline 907 & SCJFRZ2005C12.g & Serpin-ZXA (OrysaZxa) & & 1 & 3 & 20.059 & 176 \\
\hline 908 & SCACST3160C03.g & Serpin-ZXA OS & Oryza sativa subsp. japonica & 3 & 6 & 23.31 & 219 \\
\hline 909 & SCJLRT1015H07.g & Serpin & & 2 & 3 & 18.233 & 183 \\
\hline 910 & SCBFLR1083D11.g & Seryl-tRNA synthetase, cytoplasmic (EC 6.1.1.11) & & 2 & 2 & 23.439 & 223 \\
\hline 911 & SCCCLR1C01H05.g & Similar to Hordeum vulgare carboxypeptidase D & & 1 & 2 & 19.426 & 183 \\
\hline 912 & SCQSLR1061C03.g & Small nuclear ribonucleoprotein E OS & & 2 & 2 & 13.461 & 128 \\
\hline 913 & SCACLR1128F12.g & Small nuclear ribonucleoprotein Sm D1 & & 1 & 5 & 38.838 & 371 \\
\hline 914 & SCQSRT2035C10.g & Small nuclear ribonucleoprotein Sm D2 OS & & 1 & 1 & 18.176 & 168 \\
\hline 915 & SCUTLR2015F06.g & Small nuclear ribonucleoprotein Sm D3 & & 1 & 4 & 28.344 & 253 \\
\hline 916 & SCJFRZ1007C06.g & SNF1-related protein kinase catalytic subunit alpha KIN10 & Arabidopsis thaliana & 1 & 4 & 25.364 & 227 \\
\hline 917 & SCRLFL4028D02.g & Sodium/hydrogen exchanger family (Na_H_Exchanger) & & 1 & 8 & 97.395 & 885 \\
\hline 918 & SCCCLR2002G03.g & Soluble inorganic pyrophosphatase 1 , chloroplastic & & 2 & 5 & 45.602 & 427 \\
\hline 919 & SCBGAM1090F06.g & Soluble inorganic pyrophosphatase OS & Zea mays & 1 & 2 & 30.164 & 267 \\
\hline 920 & SCQGLB1029E02.g & Sphingoid long-chain bases kinase 1; LCB kinase 1 & & 1 & 9 & 34.644 & 323 \\
\hline 921 & SCCCLR1C06A01.g & Splicing factor 3B subunit $3 \mathrm{OS}$ & & 1 & 7 & 63.979 & 581 \\
\hline 922 & SCSGAD1007H09.g & Splicing factor $3 \mathrm{~B}$ subunit $3 \mathrm{OS}$ & & 5 & 9 & 39.564 & 362 \\
\hline 923 & SCMCRZ3067E12.g & Splicing factor 3B subunit 3 & & 1 & 3 & 23.609 & 212 \\
\hline 924 & SCEPRZ1011F02.g & Splicing factor, arginine/serine-rich 2 & & 1 & 9 & 42.85 & 391 \\
\hline 925 & SCVPLR1028D03.g & Staphylococcal nuclease domain-containing protein 1 & & 1 & 3 & 49.089 & 456 \\
\hline 926 & SCEQRT1029D09.g & Starch and sucrose metabolism & & 4 & 2 & 35.315 & 337 \\
\hline 927 & SCEQRT2027C10.g & Starch and sucrose metabolism & & 2 & 3 & 13.268 & 119 \\
\hline 928 & SCJFLR1035A02.g & Starch and sucrose metabolism & & 1 & 1 & 23.975 & 221 \\
\hline 929 & SCACSD2018E08.g & Stem $28 \mathrm{kDa}$ glycoprotein precursor & & 2 & 2 & 88.255 & 787 \\
\hline 930 & SCBFRZ2016G05.g & Stem-specific protein TSJT1 OS & Nicotiana tabacum & 2 & 5 & 26.864 & 245 \\
\hline 931 & SCCCLR1024C11.g & Stromal $70 \mathrm{kDa}$ heat shock-related protein & Pisum sativum & 2 & 3 & 23.918 & 223 \\
\hline 932 & SCUTSD2087C05.g & Subtilisin-chymotrypsin inhibitor-2B (Fragment) OS & Hordeum vulgare & 1 & 5 & 14.804 & 137 \\
\hline 933 & SCBGSD2049C12.g & Subtilisin-like protease OS & Arabidopsis thaliana & 1 & 2 & 42.964 & 421 \\
\hline 934 & SCCCCL2001A04.b & Subtilisin-like protease OS & Arabidopsis thaliana & 2 & 3 & 103.93 & 937 \\
\hline 935 & SCCCST1004B07.g & Subtilisin-like protease OS & Arabidopsis thaliana & 1 & 2 & 14.805 & 141 \\
\hline 936 & SCJFRT2057F01.g & Subtilisin-like protease OS & Arabidopsis thaliana & 1 & 3 & 19.252 & 184 \\
\hline 937 & SCQGLR2025F03.g & Subtilisin-like protease OS & Arabidopsis thaliana & 1 & 3 & 9.531 & 84 \\
\hline 938 & SCRFHR1007E04.g & Subtilisin-like protease OS & Arabidopsis thaliana & 1 & 1 & 55.337 & 513 \\
\hline 939 & SCRUFL3064H08.g & Subtilisin-like protease; Cucumisin-like serine protease; & & 2 & 2 & 57.103 & 508 \\
\hline 940 & SCRURT2009G03.g & Subtilisin-like protease; Cucumisin-like serine protease; & & 1 & 3 & 41.712 & 374 \\
\hline 941 & SCCCLR1001A05.g & sucrose synthase & & 1 & 4 & 26.199 & 240 \\
\hline 942 & SCCCRZ1002G07.g & sucrose synthase & & 1 & 2 & 35.663 & 316 \\
\hline 943 & SCEZLR1052C03.g & sucrose synthase & & 1 & 1 & 9.7101 & 88 \\
\hline 944 & SCEZSB1093D09.g & Sulfite oxidase OS & Arabidopsis thaliana & 1 & 2 & 46.759 & 426 \\
\hline 945 & SCCCCL3001F06.g & Sulfite oxidase; Moco-containing protein AtMCP & & 1 & 1 & 14.594 & 124 \\
\hline 946 & SCCCLR1024E11.g & Superoxide dismutase [Cu-Zn] 2 OS & Zea mays & 1 & 4 & 25.323 & 229 \\
\hline 947 & SCCCLR1048A06.g & superoxide dismutase & & 3 & 5 & 26.391 & 244 \\
\hline 948 & SCCCLR2C03D05.g & superoxide dismutase & & 1 & 2 & 51.743 & 478 \\
\hline 949 & SCCCRZ1C01D04.g & T-complex protein 1 subunit beta; TCP-1-beta; & & 1 & 1 & 35.647 & 320 \\
\hline 950 & SCCCCL4002B05.g & T-complex protein 1, epsilon subunit (TCP-1-epsilon) & & 1 & 5 & 28.234 & 274 \\
\hline 951 & SCCCCL4003F01.g & Tartrate-resistant acid phosphatase type 5 & & 1 & 2 & 30.702 & 290 \\
\hline 952 & SCEZLR1009F06.g & TCA & & 1 & 2 & 19.375 & 176 \\
\hline 953 & SCEZLB1013G07.g & Thaumatin-like protein OS & Arabidopsis thaliana & 1 & 1 & 44.164 & 414 \\
\hline 954 & SCAGLR1021H06.g & Thiol protease SEN102 OS & Hemerocallis sp. & 1 & 4 & 26.353 & 241 \\
\hline 955 & SCCCLR2001H09.g & Thioredoxin H-type OS & Triticum aestivum & 10 & 2 & 24.397 & 222 \\
\hline 956 & SCCCRZ2001C01.g & Thioredoxin $\mathrm{H}$-type OS & Triticum aestivum & 1 & 2 & 20.018 & 185 \\
\hline 957 & SCRFLB1054G11.g & Thioredoxin $\mathrm{H} 2-2 \mathrm{OS}$ & Oryza sativa subsp. japonica & 2 & 4 & 37.461 & 340 \\
\hline 958 & SCCCLR1066H08.g & Thioredoxin & & 1 & 3 & 27.888 & 245 \\
\hline 959 & SCRFLB1056D04.g & thioredoxin & & 1 & 1 & 15.744 & 143 \\
\hline 960 & SCCCHR1002F08.g & Thymus-specific serine protease; Serine protease 16; & & 1 & 3 & 93.429 & 848 \\
\hline 961 & SCJLRT1019E02.g & Thymus-specific serine protease; Serine protease 16; & & 2 & 4 & 21.982 & 210 \\
\hline 962 & SCCCLR1076H07.g & TIM21-like protein, mitochondrial OS & Bos taurus & 1 & 1 & 7.4624 & 68 \\
\hline 963 & SCCCLB1025H11.g & TOM1-like protein 2; Target of Myb-like protein 2 & & 1 & 2 & 21.278 & 198 \\
\hline 964 & SCRLAM1006C11.g & TOM1-like protein 2; Target of Myb-like protein 2 & & 1 & 2 & 25.392 & 241 \\
\hline 965 & SCCCRZ1004B05.g & Topless-related protein 1 OS & Arabidopsis thaliana & 1 & 3 & 40.754 & 372 \\
\hline 966 & SCEQRT2099E03.g & TPA: putative threonine aldolase family protein isoform 1 & Zea mays & 1 & 2 & 27.672 & 263 \\
\hline 967 & SCCCLR1024A05.g & Transaldolase OS & & 1 & 3 & 18.688 & 180 \\
\hline 968 & SCVPLB1018F09.g & Transcription factor BTF3 OS & & 1 & 1 & 19.904 & 188 \\
\hline 969 & SCAGLR2011E07.g & Transcription factor BTF3 & & 1 & 1 & 22.501 & 207 \\
\hline 970 & SCJFLR1073B11.g & Transcription factor BTF3 & & 1 & 8 & 37.485 & 345 \\
\hline 971 & SCUTRZ3071D08.g & Transcription factor Pur-alpha 1 OS & Arabidopsis thaliana & 1 & 3 & 16.723 & 155 \\
\hline 972 & SCCCCL3003A08.b & Transketolase, chloroplastic OS & Zea mays & 1 & 1 & 35.425 & 336 \\
\hline 973 & SCEZLR1031E10.g & Translationally-controlled tumor protein homolog OS & Zea mays & 1 & 2 & 22.504 & 204 \\
\hline 974 & SCQGLR2017B05.g & Transmembrane protein 214-A & & 1 & 4 & 20.49 & 189 \\
\hline 975 & SCRFLR2034G09.g & Triosephosphate isomerase, cytosolic OS & Zea mays & 2 & 2 & 11.978 & 110 \\
\hline 976 & SCMCST1051A04.g & Tripeptidyl-peptidase 2 OS & Homo sapiens & 1 & 6 & 37.96 & 352 \\
\hline 977 & SCQGRT1039H01.g & Tripeptidyl-peptidase 2; Tripeptidyl-peptidase II & & 1 & 2 & 53.173 & 463 \\
\hline 978 & SCRLAM1014G04.g & tRNA nucleotidyltransferase, mitochondrial & & 1 & 9 & 35.293 & 314 \\
\hline 979 & SCEZLB1010A08.g & tRNA pseudouridine synthase $1 \mathrm{OS}$ & & 2 & 2 & 21.433 & 192 \\
\hline 980 & SCEPAM1015B01.g & Tryptophanyl-tRNA synthetase (EC 6.1.1.2 & & 1 & 11 & 20.126 & 192 \\
\hline 981 & SCCCRZ2002C09.g & Tubulin alpha-1 chain OS & Eleusine indica & 1 & 3 & 23.604 & 217 \\
\hline 982 & SCEQRT2025E08.g & Tubulin alpha-2 chain (Alpha-2-tubulin) & & 1 & 2 & 15.324 & 153 \\
\hline 983 & SCCCCL3001C07.b & Tubulin alpha-3 chain OS & Hordeum vulgare & 1 & 2 & 79.275 & 725 \\
\hline 984 & SCCCLR1C07G05.g & Tubulin alpha- 6 chain OS & Zea mays & 1 & 3 & 42.812 & 400 \\
\hline 985 & SCVPLR1049D05.g & Tubulin beta- 3 chain OS & Oryza sativa subsp. japonica & 1 & 1 & 57.899 & 519 \\
\hline 986 & SCJLLR1054B02.g & Tubulin beta- 5 chain OS & Zea mays & 1 & 2 & 34.245 & 329 \\
\hline 987 & SCEZLB1009D02.g & U2 small nuclear ribonucleoprotein A; U2 snRNP-A & & 1 & 1 & 25.088 & 239 \\
\hline 988 & SCEZLR1031H11.g & U2 small nuclear ribonucleoprotein B & & 1 & 9 & 20.895 & 188 \\
\hline 989 & SCSGFL1083D09.g & U6 snRNA-associated Sm-like protein LSm2 OS & & 1 & 3 & 13.647 & 130 \\
\hline 990 & SCCCLR2002D01.g & U6 snRNA-associated Sm-like protein LSm3 & & 1 & 2 & 36.457 & 337 \\
\hline 991 & SCRLAM2051E04.g & U6 snRNA-associated Sm-like protein LSm5 OS & & 1 & 3 & 22.138 & 202 \\
\hline
\end{tabular}


Continuaçao Anexo 2.

\begin{tabular}{|c|c|c|c|c|c|c|c|}
\hline 992 & SCVPLR2027B10.g & U6 snRNA-associated Sm-like protein LSm6 & & 1 & 2 & 32.251 & 308 \\
\hline 993 & SCBGRT3075H03.g & Ubiquitin carboxyl-terminal hydrolase 12 OS & Arabidopsis thaliana & 1 & 5 & 50.318 & 466 \\
\hline 994 & SCCCCL2001C05.b & Ubiquitin fusion degradation protein 1 homolog & & 1 & 2 & 41.545 & 382 \\
\hline 995 & SCRLLR1131E01.g & Ubiquitin OS & Triticum aestivum & 1 & 9 & 36.224 & 327 \\
\hline 996 & SCEZLB1014D11.g & Ubiquitin thioesterase OTU1 & & 1 & 1 & 38.065 & 335 \\
\hline 997 & SCCCLB1004H02.g & Ubiquitin-activating enzyme E1 1 OS & Triticum aestivum & 1 & 4 & 44.727 & 424 \\
\hline 998 & SCCCLR1C07A06.g & Ubiquitin-conjugating enzyme E2 11 OS & Arabidopsis thaliana & 1 & 6 & 20.85 & 182 \\
\hline 999 & SCCCRZ2C04H01.g & Ubiquitin-conjugating enzyme E2 variant $1 \mathrm{C}$ OS & Arabidopsis thaliana & 1 & 3 & 16.601 & 148 \\
\hline 1000 & SCCCST2001G12.g & Ubiquitin-like domain-containing CTD phosphatase OS & Arabidopsis thaliana & 2 & 2 & 27.273 & 258 \\
\hline 1001 & SCAGRT3050B06.g & Ubiquitin-like protein SMT3 OS & Oryza sativa subsp. japonica & 3 & 25 & 39.753 & 355 \\
\hline 1002 & SCSFRT2068D06.g & Uclacyanin-2 OS & Arabidopsis thaliana & 1 & 2 & 19.787 & 193 \\
\hline 1003 & SCCCRZ2001D09.g & UDP-D-glucuronate decarboxylase & & 1 & 10 & 35.507 & 343 \\
\hline 1004 & SCJFLR1013H10.g & UDP-glucose dehydrogenase & & 1 & 1 & 45.05 & 403 \\
\hline 1005 & SCQGLR1019G02.g & UDP-glucose dehydrogenase & & 2 & 7 & 59.778 & 544 \\
\hline 1006 & SCJLRT2051F02.g & UDP-glucose pyrophosphorylase & & 1 & 2 & 25.771 & 228 \\
\hline 1007 & SCQGLR1062D04.g & UDP-glucose pyrophosphorylase & & 1 & 1 & 23.72 & 227 \\
\hline 1008 & SCEZAM2031D12.g & UDP-sugar pyrophosphorylase & & 1 & 1 & 39.505 & 348 \\
\hline 1009 & SCCCCL3002C05.b & Uncharacterized basic helix-loop-helix protein At1g06150 & Arabidopsis thaliana & 1 & 2 & 19.169 & 175 \\
\hline 1010 & SCCCLR1048C12.g & Uncharacterized glycosyltransferase At1g55740 & & 1 & 5 & 19.679 & 181 \\
\hline 1011 & SCBFRZ2017F08.g & Uncharacterized protein At2g17340 & & 6 & 19 & 48.016 & 423 \\
\hline 1012 & SCQGLR1085C12.g & Uncharacterized protein At2g34160 & & 1 & 9 & 66.952 & 597 \\
\hline 1013 & SCRLFL8053A03.g & Uncharacterized protein At2g39795, mitochondrial OS & Arabidopsis thaliana & 1 & 3 & 23.285 & 226 \\
\hline 1014 & SCCCCL4006D02.g & Uncharacterized protein At3g15000, mitochondrial OS & Arabidopsis thaliana & 1 & 4 & 43.306 & 402 \\
\hline 1015 & SCJLRT1021E02.g & Uncharacterized protein At3g48680, mitochondrial & & 1 & 1 & 44.025 & 399 \\
\hline 1016 & SCQSLB1052C11.g & Uncharacterized protein At4g06744 OS & Arabidopsis thaliana & 3 & 4 & 23.163 & 223 \\
\hline 1017 & SCMCST1057F02.g & Uncharacterized protein At4g06744; & & 2 & 2 & 56.071 & 514 \\
\hline 1018 & SCRULB1059D03.g & Uncharacterized protein At4g28440 OS & Arabidopsis thaliana & 4 & 3 & 24.734 & 246 \\
\hline 1019 & SCAGLR1064D02.g & Uncharacterized protein At5g01610 OS & Arabidopsis thaliana & 2 & 13 & 34.28 & 301 \\
\hline 1020 & SCCCCL1001B08.b & Uncharacterized protein At5g01610 OS & Arabidopsis thaliana & 1 & 3 & 60.5 & 532 \\
\hline 1021 & SCCCRT1004C12.g & Uncharacterized protein At5g01610 OS & Arabidopsis thaliana & 1 & 4 & 99.376 & 894 \\
\hline 1022 & SCEPAM2057B02.g & Uncharacterized protein At5g22580 OS & Arabidopsis thaliana & 1 & 5 & 37.592 & 340 \\
\hline 1023 & SCJFLR1035G04.g & Uncharacterized protein At5g39570 & & 1 & 4 & 42.787 & 394 \\
\hline 1024 & SCSGHR1072H03.g & Uncharacterized protein DDB_G0288155 OS & Dictyostelium discoideum & 3 & 6 & 70.154 & 637 \\
\hline 1025 & SCJLLR1054C04.g & Uncharacterized protein DDB_G0288155 OS & Dictyostelium discoideum & 2 & 10 & 23.764 & 200 \\
\hline 1026 & SCJLRT2049D12.g & uncharacterized protein LOC100276726 & Zea mays & 1 & 3 & 19.49 & 180 \\
\hline 1027 & SCBGFL4048C01.g & Uncharacterized protein Os08g0359500 OS & Oryza sativa subsp. japonica & 1 & 5 & 43.977 & 401 \\
\hline 1028 & SCVPLR2012D11.g & Uncharacterized protein YML050W OS & Saccharomyces cerevisiae & 2 & 4 & 18.861 & 173 \\
\hline 1029 & SCQGLB1038H08.g & Uncharacterized RNA-binding protein C23E6.01c & & 3 & 15 & 44.576 & 402 \\
\hline 1030 & SCQSST1038C02.g & undefined & & 2 & 6 & 80.454 & 737 \\
\hline 1031 & SCCCRZ2001C11.g & Universal stress protein A-like protein & & 4 & 15 & 104.45 & 929 \\
\hline 1032 & SCCCLR1066F11.g & UPF0160 protein MYG1, mitochondrial OS & Bos taurus & 1 & 2 & 21.415 & 206 \\
\hline 1033 & SCRFLR1055F07.g & UPF0424 protein OS & Dictyostelium discoideum & 1 & 5 & 77.211 & 690 \\
\hline 1034 & SCJLST1019C10.g & UPF0555 protein KIAA0776 & & 1 & 2 & 32.493 & 293 \\
\hline 1035 & SCSGLR1045A02.g & Urease (EC 3.5.1.5) (Urea amidohydrolase) & & 1 & 2 & 25.037 & 231 \\
\hline 1036 & SCAGLR1043D04.g & V-type proton ATPase catalytic subunit A OS & Daucus carota & 4 & 3 & 27.961 & 251 \\
\hline 1037 & SCQGRT1039F06.g & V-type proton ATPase subunit B 1; V-ATPase subunit B 1 & & 1 & 2 & 24.137 & 222 \\
\hline 1038 & SCVPRZ2039D07.g & V-type proton ATPase subunit C; V-ATPase subunit C & & 1 & 2 & 41.685 & 389 \\
\hline 1039 & SCCCLB1025B04.g & V-type proton ATPase subunit E OS & Citrus limon & 1 & 2 & 17.965 & 174 \\
\hline 1040 & SCEQLR1091F08.g & V-type proton ATPase subunit F OS & Arabidopsis thaliana & 4 & 3 & 38.952 & 395 \\
\hline 1041 & SCBGLR1082H03.g & V-type proton ATPase subunit G 1 OS & Nicotiana tabacum & 1 & 1 & 4.4131 & 39 \\
\hline 1042 & SCQSLR1018F01.g & Vacuolar protein sorting-associated protein 29 & & 2 & 4 & 52.97 & 475 \\
\hline 1043 & SCQGLR1086C02.g & Vacuolar-processing enzyme OS & Citrus sinensis & 2 & 3 & 33.736 & 305 \\
\hline 1044 & \begin{tabular}{|l} 
SCSFRT2072D01.g \\
\end{tabular} & Vacuolar-sorting receptor 1 precursor (AtVSR1) & & 1 & 2 & 48.951 & 431 \\
\hline 1045 & SCCCCL4008F12.g & Valyl-tRNA synthetase OS & Arabidopsis thaliana & 1 & 7 & 56.041 & 511 \\
\hline 1046 & SCBFLR1039G10.g & VAMP-like protein YKT61 OS & Arabidopsis thaliana & 3 & 4 & 45.327 & 416 \\
\hline 1047 & SCEQRT1033D01.g & vegetative storage protein (acid phosphatase) & & 1 & 5 & 23.852 & 225 \\
\hline 1048 & SCEQLB1067F01.g & vegetative storage protein & & 4 & 3 & 69.501 & 645 \\
\hline 1049 & SCJLRT1017E07.g & Vesicle-associated membrane protein 711 & & 1 & 13 & 39.285 & 345 \\
\hline 1050 & SCSGSB1009F10.g & Vesicle-associated membrane protein 725 OS & Arabidopsis thaliana & 1 & 18 & 121.03 & 1102 \\
\hline 1051 & SCJLST1022F12.g & Vesicle-fusing ATPase & & 1 & 10 & 71.176 & 648 \\
\hline 1052 & SCCCCL4009B07.g & Villin-2 & & 1 & 8 & 64.042 & 597 \\
\hline 1053 & SCCCCL4004D02.g & Villin-4 & & 2 & 13 & 94.441 & 851 \\
\hline 1054 & SCCCCL4005G09.g & Villin-4 & & 1 & 3 & 54.074 & 517 \\
\hline 1055 & SCCCLR1024E02.g & Water stress & & 1 & 10 & 84.244 & 762 \\
\hline 1056 & \begin{tabular}{|l} 
SCCCLR1067B04.g \\
\end{tabular} & Water stress & & 2 & 4 & 31.561 & 276 \\
\hline 1057 & SCCCLR1C01B10.g & Water stress & & 1 & 2 & 51.47 & 469 \\
\hline 1058 & \begin{tabular}{|l|} 
SCCCRT1002F07.g \\
\end{tabular} & Water stress & & 5 & 9 & 50.366 & 457 \\
\hline 1059 & SCCCRZ2002D07.g & Water stress & & 2 & 4 & 31.669 & 277 \\
\hline 1060 & SCEPRZ1010F04.g & Water stress & & 2 & 7 & 40.802 & 381 \\
\hline 1061 & SCJFRT1009F06.g & Water stress & & 2 & 6 & 37.215 & 335 \\
\hline 1062 & SCEZLB1010A03.g & Water stress & & 1 & 10 & 35.487 & 330 \\
\hline 1063 & SCJFRZ1007A10.g & Water stress & & 1 & 5 & 30.614 & 305 \\
\hline 1064 & SCILLR1033F07.g & Water stress & & 1 & 4 & 18.269 & 179 \\
\hline 1065 & SCSFRT2069E03.g & Water stress & & 1 & 5 & 44.774 & 409 \\
\hline 1066 & SCSGAD1143E07.g & Xaa-Pro aminopeptidase 1 OS & Bos taurus & 4 & 21 & 71.017 & 666 \\
\hline
\end{tabular}


Continuaçao Anexo 2.

\begin{tabular}{|c|c|c|c|c|c|c|c|}
\hline 1067 & SCCCAM1002E08.g & Xaa-Pro aminopeptidase 1 OS & Rattus norvegicus & 1 & 1 & 22.864 & 215 \\
\hline 1068 & SCCCFL1001E01.g & Xylem cysteine proteinase 2 OS & Arabidopsis thaliana & 2 & 15 & 77.514 & 716 \\
\hline 1069 & SCCCCL3140B03.g & Xylose isomerase & & 1 & 1 & 18.92 & 181 \\
\hline 1070 & SCRURT2012C09.g & Zeamatin OS & Zea mays & 1 & 3 & 24.084 & 216 \\
\hline 1071 & SCCCLB1002C04.g & zinc finger protein/alfin-like & & 1 & 5 & 21.335 & 201 \\
\hline 1072 & SCCCCL3003B06.b & & & 2 & 11 & 39.421 & 364 \\
\hline 1073 & SCCCST2001A03.g & & & 1 & 6 & 29.801 & 263 \\
\hline 1074 & SCEPAM1021H07.g & & & 7 & 9 & 22.95 & 218 \\
\hline 1075 & SCEPAM2055E11.g & & & 1 & 7 & 32.151 & 299 \\
\hline 1076 & SCEQAM2039A03.g & & & 1 & 2 & 46.776 & 414 \\
\hline 1077 & SCEQRT2096H01.g & & & 1 & 2 & 19.539 & 188 \\
\hline 1078 & SCEZLR1052D03.g & & & 4 & 7 & 51.075 & 449 \\
\hline 1079 & SCQSFL3033G08.g & & & 3 & 4 & 23.084 & 222 \\
\hline 1080 & SCRULB1060E05.g & & & 1 & 3 & 65.041 & 577 \\
\hline 1081 & SCSFSB1103F04.g & & & 2 & 3 & 48.752 & 436 \\
\hline 1082 & SCVPRT2084B02.g & & & 2 & 3 & 64.07 & 592 \\
\hline
\end{tabular}


Anexo 3. A distribuição quantitativa relativa dessas 525 proteínas entre os segmentos é apresentado, na qual observa-se que a razão entre os segmentos 1 e 2 (1/2) foi distinta em relação aos demais segmentos, com muitas proteínas que aumentam em abundância relativa do segmento 1 para o 2 . É possível visualizar a separação em 2 clusters do heatmap que distinguem $1 / 2$ do restante das razões entre os segmentos, em vermelho as proteínas que estão mais expressas na razão entre $1 / 2$ e em verde as que estão menos expressas nesta transição. Grandes diferenças ocorrem entre os segmentos $1 / 2$, principalmente pelo aumento de expressão de proteínas no segmento 2 que mantém-se em altos níveis na transição 2/3 bem como nas transições posteriores (observado pela área inferior do heatmap dominada pela cor verde).

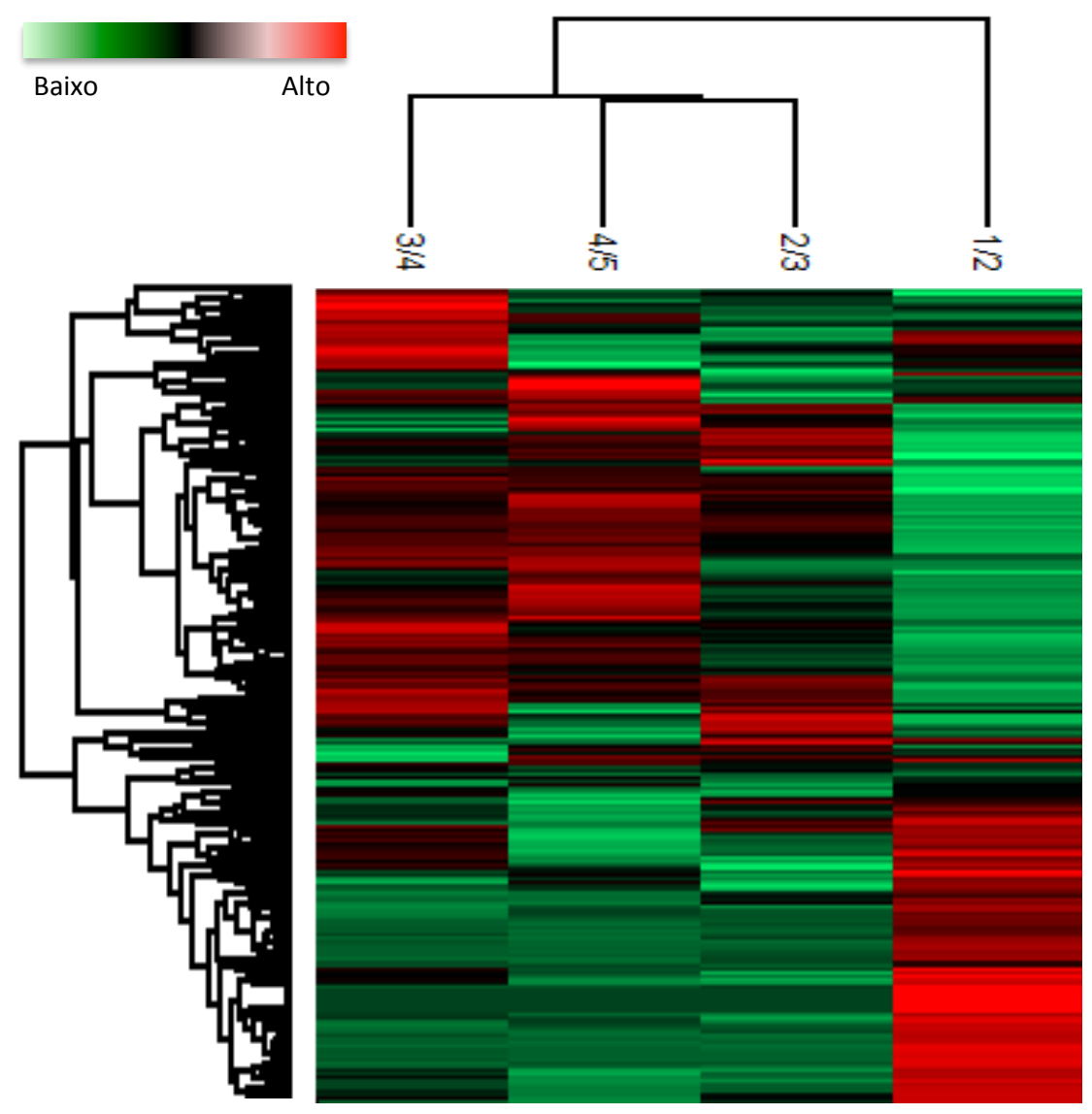

Anexo 3. Heatmap com 525 proteínas identificadas nas raízes de cana - razões normalizadas (Z-score) entre os segmentos 1/2, 2/3, 3/4 e 4/5 (n=5). Agrupamento hierárquico seguindo a média euclidiana das razões entre os segmentos. Linhas indicam proteínas individuais que são coloridas de acordo com a densidade das proteínas e suas razões. 


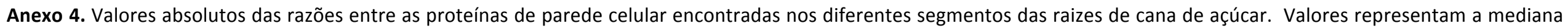

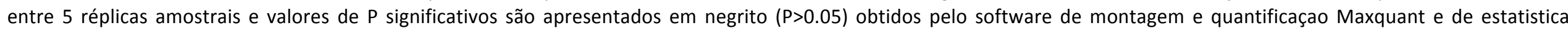
Perseus. Termos GO (processo biológico, componente celular e função molecular) foram obtidos com as ferramentas do software Blast2GO.

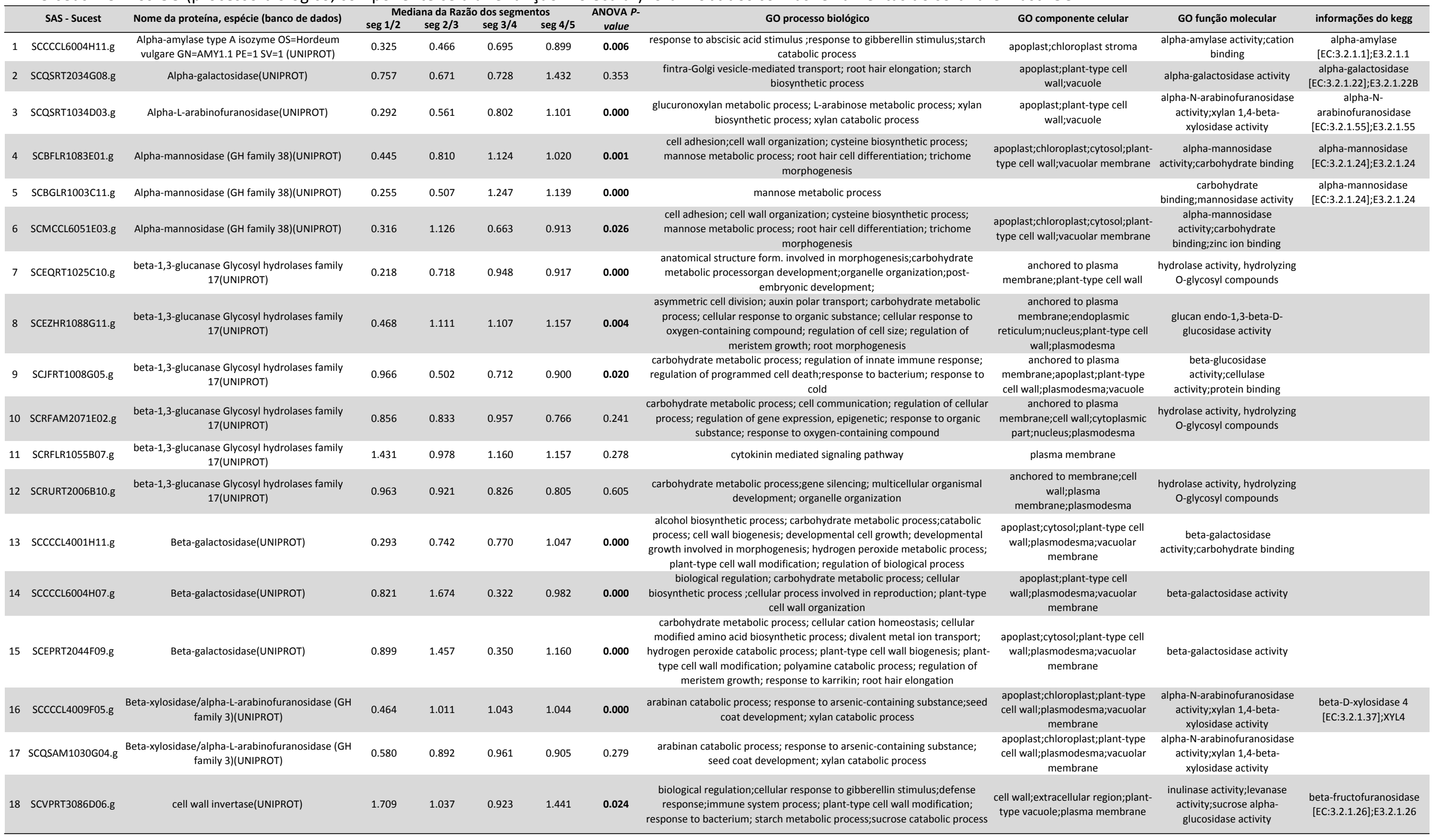




\section{Continuação Anexo 4.}

\begin{tabular}{|c|c|c|c|c|c|c|c|c|c|c|c|}
\hline & SAS - Sucest & Nome da proteína, espécie (banco de dados) & $\mathrm{Me}$ & ana da Raz & dos segm & tos & ANOVA P- & GO processo biológico & GO componente celular & GO função molecular & informações do kegg \\
\hline 19 & SCCCLR2CO1H02.g & $\begin{array}{l}\text { Endo-1,3;1,4-beta-D-glucanase OS=Zea mays } \\
\qquad \mathrm{PE}=1 \mathrm{SV}=1 \text { (UNIPROT) }\end{array}$ & 1.208 & 1.001 & 1.328 & 0.696 & 0.083 & $\begin{array}{l}\text { glycolysis;Golgi organization;hyperosmotic response;response to cadmium } \\
\text { ion;response to salt stress;response to temperature stimulus;water } \\
\text { transport }\end{array}$ & $\begin{array}{l}\text { apoplast;cytosol;nucleus;plasma } \\
\text { membrane }\end{array}$ & hydrolase activity & $\begin{array}{c}\text { carboxymethylenebutenol } \\
\text { dase } \\
{[\text { [EC:3.1. } 45] ; \text { E3.1.1.45 }}\end{array}$ \\
\hline 20 & SCVPRT2081E09.g & $\begin{array}{l}\text { Endo-1,3(4)-beta-glucanase 1;Endo-1,4-beta- } \\
\text { glucanase 1;Endo-1,3-beta-glucanase } \\
\text { 1;Laminarinase-1;(UNIPROT) }\end{array}$ & 0.591 & 0.757 & 0.814 & 1.118 & 0.052 & $\begin{array}{l}\text { amino acid import;cell wall macromolecule catabolic process;endoplasmic } \\
\text { reticulum unfolded protein response; } E \text { to Golgi vesicle-mediated } \\
\text { transport; N-terminal protein myristoylation }\end{array}$ & & $\begin{array}{l}\text { glucan endo-1,3-beta- } \\
\text { glucanase activity, C-3 } \\
\text { substituted reducing } \\
\text { group; ;glucan endo-1,4-beta- } \\
\text { glucanase activity, C-3 } \\
\text { substituted reducing group }\end{array}$ & \\
\hline 21 & SCCCCL4006H09.g & Expansin(UNIPROT) & 1.387 & 0.923 & 1.251 & 1.163 & 0.746 & $\begin{array}{l}\text { cell growth; developmental growth involved in morphogenesis; plant-type } \\
\text { cell wall modification; sexual reproduction; trichoblast differentiation }\end{array}$ & $\begin{array}{l}\text { extracellular region; Golgi } \\
\text { apparatus; plant-type cell wall; } \\
\text { plasmodesma }\end{array}$ & & \\
\hline 22 & SCSGLV1004F11.g & Expansin(UNIPROT) & 0.943 & 1.243 & 0.981 & 0.797 & 0.195 & $\begin{array}{l}\text { organelle organization; plant-type cell wall loosening; plant-type cell wall } \\
\text { modification involved in multidimensional cell growth; regulation of } \\
\text { stomatal movement; response to gibberellin stimulus; response to red } \\
\text { light; syncytium formation; unidimensional cell growth }\end{array}$ & $\begin{array}{l}\text { chloroplast;cytosol;extracellular } \\
\text { region;plant-type cell } \\
\text { wall;plasmodesma }\end{array}$ & $\begin{array}{l}\text { structural constituent of cell } \\
\text { wall }\end{array}$ & \\
\hline 23 & SCEPLR1051B04.g & Fasciclin-like arabinogalactan protein(UNIPROT) & 0.828 & 1.034 & 0.845 & 1.046 & 0.265 & $\begin{array}{l}\text { alcohol biosynthetic process; cell growth; cellular component organization; } \\
\text { plant-type cell wall organization or biogenesis; regulation of hormone } \\
\text { levels;shoot system development; single-organism transport; steroid } \\
\text { biosynthetic process; trichoblast differentiation }\end{array}$ & $\begin{array}{l}\text { anchored to plasma } \\
\text { membrane;cell wall;vacuolar } \\
\text { membrane }\end{array}$ & & \\
\hline 24 & SCQGRT1040D08.g & Fasciclin-like arabinogalactan protein(UNIPROT) & 2.209 & 1.195 & 2.255 & 0.733 & 0.471 & $\begin{array}{l}\text { alcohol biosynthetic process;biological regulation;secondary cell wall } \\
\text { biogenesis;steroid biosynthetic process; trichoblast differentiation }\end{array}$ & $\begin{array}{l}\text { anchored to plasma membrane; } \\
\text { Golgi apparatus; plant-type cell } \\
\text { wall; plasmodesma }\end{array}$ & & \\
\hline 25 & SCQSLR1040G04.g & Fasciclin-like arabinogalactan protein(UNIPROT) & 0.490 & 1.365 & 1.159 & 1.138 & 0.007 & $\begin{array}{l}\text { acetyl-CoA metabolic process; brassinosteroid biosynthetic process; cell } \\
\text { growth; plant-type cell wall organization; regulation of meristem growth; } \\
\text { root development; secondary cell wall biogenesis; sterol biosynthetic } \\
\text { process }\end{array}$ & $\begin{array}{l}\text { anchored to plasma membrane; } \\
\text { cell wall; cytoplasmic part; } \\
\text { intracellular membrane-bounded } \\
\text { organelle }\end{array}$ & & \\
\hline 26 & SCRFLR1034D04.g & Fasciclin-like arabinogalactan protein(UNIPROT) & 0.486 & 1.074 & 1.472 & 1.133 & 0.002 & $\begin{array}{l}\text { brassinosteroid biosynthetic process;cell growth;secondary cell wall } \\
\text { biogenesis; trichoblast differentiation }\end{array}$ & $\begin{array}{l}\text { anchored to plasma } \\
\text { membrane;Golgi apparatus;plant- } \\
\text { type cell wall;plasmodesma }\end{array}$ & & \\
\hline 27 & SCVPRZ2036F10.g & Fasciclin-like arabinogalactan protein(UNIPROT) & 0.598 & 0.955 & 1.158 & 0.973 & 0.198 & $\begin{array}{l}\text { acetyl-CoA metabolic process;;rassinosteroid biosynthetic process; cell } \\
\text { growth; plant-type cell wall organization; regulation of meristem growth; } \\
\text { root development; secondary cell wall biogenesis; sterol biosynthetic } \\
\text { process }\end{array}$ & $\begin{array}{l}\text { anchored to plasma } \\
\text { membrane;cell wall;cytoplasmic } \\
\text { part;intracellular membrane- } \\
\text { bounded organelle }\end{array}$ & & \\
\hline 28 & SCCCCL4011H08.g & Fructose and Mannose Metabolism(UNIPROT) & 2.331 & 1.276 & 2.448 & 0.509 & 0.000 & $\begin{array}{l}\text { acetyl-CoA biosynthetic process; cellular response to phosphate } \\
\text { starvation; chromatin silencing; embryo development ending in seed } \\
\text { dormancy; fructose } 6 \text {-phosphate metabolic process; } \text { galactolipid } \\
\text { biosynthetic process; glycolysis; histone } \mathrm{H3}-\mathrm{Kg} \\
\text { methylation;photosynthesis; response to cadmium ion;response to } \\
\text { fructose stimulus; response to glucose stimulus; response to sucrose } \\
\text { stimulus }\end{array}$ & $\begin{array}{l}\text { cell } \\
\text { wall;cytosol;membrane;pyrophosp } \\
\text { hate-dependent } \\
\text { phosphofructokinase complex, } \\
\text { beta-subunit complex }\end{array}$ & $\begin{array}{l}\text { 6-phosphofructokinase } \\
\text { activity;ATP } \\
\text { binding;diphosphate-fructose- } \\
\text { 6-phosphate 1- } \\
\text { phosphotransferase activity }\end{array}$ & $\begin{array}{l}\text { E2.7.1.90; pyrophosphate- } \\
\text { fructose-6-phosphate 1- } \\
\text { phosphotransferase } \\
\text { [EC:2.7.1.90] }\end{array}$ \\
\hline 29 & SCCCLR1048B08.g & Fructose and Mannose Metabolism(UNIPROT) & 1.422 & 0.939 & 0.873 & 1.059 & 0.754 & $\begin{array}{l}\text { aerobic respiration; calcium ion transport; cysteine biosynthetic process; } \\
\text { gluconeogenesis; Golgi organization; hyperosmotic response; pentose- } \\
\text { phosphate shunt; photorespiration ;primary root development; regulation } \\
\text { of protein localization; response to cadmium ion; response to misfolded } \\
\text { protein; response to salt stress ;response to temperature stimulus; water } \\
\text { transport }\end{array}$ & $\begin{array}{l}\text { apoplast; cell wall; chloroplast } \\
\text { envelop; chloroplast stroma; } \\
\text { cytosol; Golgi apparatus; } \\
\text { mitochondrion; plasma } \\
\text { membrane; plasmodesma; } \\
\text { thylakoid; vacuolar membrane }\end{array}$ & $\begin{array}{l}\text { copper ion binding;triose- } \\
\text { phosphate isomerase activity }\end{array}$ & $\begin{array}{l}\text { TPI;triosephosphate } \\
\text { isomerase (TIM) } \\
\text { [EC:5.3.1.1] }\end{array}$ \\
\hline 30 & SCEPRZ1009B12.g & Fructose and Mannose Metabolism(UNIPROT) & 1.785 & 0.831 & 0.977 & 0.878 & 0.002 & $\begin{array}{l}\text { aerobic respiration; calcium ion transport; cysteine biosynthetic process; } \\
\text { gluconeogenesis; Golgi organization; hyperosmotic response; pentose- } \\
\text { phosphate shunt; photorespiration ;primary root development; regulation } \\
\text { of protein localization; response to cadmium ion; response to misfolded } \\
\text { protein; response to salt stress ;response to temperature stimulus; water } \\
\text { transport }\end{array}$ & $\begin{array}{l}\text { apoplast; cell wall; chloroplast } \\
\text { envelop; chloroplast stroma; } \\
\text { cytosol; Golgi apparatus; } \\
\text { mitochondrion; plasma } \\
\text { membrane; plasmodesma; } \\
\text { thylakoid; vacuolar membrane }\end{array}$ & $\begin{array}{l}\text { copper ion binding;triose- } \\
\text { phosphate isomerase activity }\end{array}$ & $\begin{array}{l}\text { TPl;triosephosphate } \\
\text { isomerase (TIM) } \\
\text { [EC:5.3.1.1] }\end{array}$ \\
\hline
\end{tabular}




\section{Continuação Anexo 4.}

\begin{tabular}{|c|c|c|c|c|c|c|c|c|c|c|c|}
\hline & SAS - Sucest & Nome da proteína, espécie (banco de dados) & $\begin{array}{l}\text { Mec } \\
\text { seg } 1 / 2\end{array}$ & $\begin{array}{l}\text { Ina da Raz } \\
\text { seg } 2 / 3\end{array}$ & $\begin{array}{l}\text { dos segm } \\
\text { seg } 3 / 4\end{array}$ & $\begin{array}{l}\text { tos } \\
\text { seg } 4 / 5\end{array}$ & $\begin{array}{l}\text { ANOVA P- } \\
\text { value }\end{array}$ & GO processo biológico & GO componente celular & GO função molecular & informações do kegg \\
\hline 31 & SCCCRZ1001D04.g & Galactose metabolism(UNIPROT) & 1.127 & 1.283 & 1.449 & 0.701 & 0.022 & $\begin{array}{l}\text { cellular calcium ion homeostasis; defense response to bacterium; } \\
\text { detection of gravity; ; galactose catabolic process; plant-type cell wall } \\
\text { organization; polysaccharide catabolic process; positive regulation of } \\
\text { catalytic activity; response to cadmium ion;response to cold; response to } \\
\text { nitrate; response to salt stress; starch biosynthetic process; trehalose } \\
\text { biosynthetic process }\end{array}$ & $\begin{array}{l}\text { apoplast; chloroplast envelope; } \\
\text { chloroplast stroma ; cytosol; } \\
\text { mitochondrion; nucleus; plasma } \\
\text { membrane }\end{array}$ & $\begin{array}{c}\text { magnesium ion } \\
\text { binding; phosphoglucomutase } \\
\text { activity }\end{array}$ & $\begin{array}{l}\text { pgm;phosphoglucomutase } \\
\text { [EC:5.4.2.2. }\end{array}$ \\
\hline 32 & SCAGLR1021F11.g & Glycosyl hydrolase family 1(UNIPROT) & 0.416 & 0.526 & 0.718 & 0.823 & 0.000 & $\begin{array}{l}\text { carbohydrate metabolics; cellular response to cold; defense response by } \\
\text { callose deposition in cell wall; defense response to fungus; induced } \\
\text { systemic resistance; negative regulation of defense response; response to } \\
\text { salt stress; response to symbiotic fungus }\end{array}$ & $\begin{array}{l}\text { apoplast ;chloroplast envelope; } \\
\text { cytosolic ribosome; endoplasmic } \\
\text { reticulum; ER body; Golgi } \\
\text { apparatus; membrane ;nucleus; } \\
\text { peroxisome; plant-type cell wall; } \\
\text { plasmodesma; vacuole }\end{array}$ & $\begin{array}{l}\text { beta-mannosidase } \\
\text { activity;cellobiose glucosidase } \\
\text { activity;copper ion } \\
\text { binding,fucosidase } \\
\text { activity;phosphatidic acid } \\
\text { binding;protease binding }\end{array}$ & beta-glucosidase \\
\hline 33 & scCCCL3001B10.b & Glycosyl hydrolase family 1(UNIPROT) & 0.508 & 0.923 & 0.968 & 1.276 & 0.000 & $\begin{array}{l}\text { carbohydrate metabolic process; cellular response to ethylene stimulus; } \\
\text { cellular response to iron ion; ;ellular response to nitric oxide; lignin } \\
\text { biosynthetic process; pollen tube growth; regulation of cellular process; } \\
\text { response to carbohydrate stimulus; response to other organism; response } \\
\text { to salt stress }\end{array}$ & $\begin{array}{l}\text { apoplast;chloroplast; cytosolic } \\
\text { ribosome;Golgi apparatus;plant- } \\
\text { type cell wall;plasmodesma }\end{array}$ & $\begin{array}{l}\text { beta-mannosidase } \\
\text { activity;cellobiose glucosidase } \\
\text { activityciconiferin beta- } \\
\text { glucosidase activity }\end{array}$ & $\begin{array}{l}\text { beta-glucosidase } \\
\text { [EC:3.2.1.21];bg|B }\end{array}$ \\
\hline 34 & SCEQHR1082B01.g & Glycosyl hydrolase family 1 (UNIPROT) & 1.681 & 0.537 & 0.659 & 0.833 & 0.000 & $\begin{array}{l}\text { carbohydrate metabolic process; glucosinolate metabolic process; pollen } \\
\text { tube growth; response to other organism; response to salt stress }\end{array}$ & $\begin{array}{l}\text { apoplast ; chloroplast; cytosolic } \\
\text { ribosome; Golgi apparatus; } \\
\text { membrane; plant-type cell wall; } \\
\text { plasmodesma }\end{array}$ & $\begin{array}{l}\text { beta-mannosidase } \\
\text { activity;cellobiose glucosidase } \\
\text { activity;esculin beta- } \\
\text { glucosidase } \\
\text { activity; thioglucosidase } \\
\text { activity }\end{array}$ & $\begin{array}{l}\text { beta-glucosidase } \\
{[E C: 3.2 \cdot 1.21] ; \in 3.2 \cdot 1 \cdot 21}\end{array}$ \\
\hline 35 & SCEQLB1066E08.g & Glycosyl hydrolase family 1(UNIPROT) & 0.663 & 1.035 & 1.125 & 0.869 & 0.192 & $\begin{array}{l}\text { carbohydrate metabolic process; cellular component organization; cellular } \\
\text { response to ethylene stimulus; lignin biosynthetic process; response to } \\
\text { carbohydrate stimulus }\end{array}$ & $\begin{array}{l}\text { apoplast; chloroplast; cytosolic } \\
\text { ribosome;Golgi apparatus;plant- } \\
\text { type cell wall;plasmodesma }\end{array}$ & $\begin{array}{l}\text { beta-mannosidase } \\
\text { activity;cellobiose glucosidase } \\
\text { activity }\end{array}$ & $\begin{array}{l}\text { beta-glucosidase } \\
\text { [EC:3.2.1.21];bg|B }\end{array}$ \\
\hline 36 & SCJFLR1017E03.g & Glycosyl hydrolase family 1(UNIPROT) & 0.700 & 1.093 & 1.129 & 1.083 & 0.168 & $\begin{array}{l}\text { carbohydrate metabolic process; cellular response to ethylene stimulus; } \\
\text { lignin biosynthetic process }\end{array}$ & $\begin{array}{l}\text { apoplast; ;chloroplast; cytosolic } \\
\text { ribosome; Golgi apparatus; } \\
\text { membrane; plant-type cell wall; } \\
\text { plasmodesma }\end{array}$ & $\begin{array}{l}\text { beta-mannosidase } \\
\text { activity;cellobiose glucosidase } \\
\text { activity;coniferin beta- } \\
\text { glucosidase activity;esculin } \\
\text { beta-glucosidase activity }\end{array}$ & \\
\hline 37 & SCAGRT2037A11.g & $\begin{array}{l}\text { Glycosyl hydrolase family } 3 \text { protein } \\
\text { (Xylosidase)(UNIPROT) }\end{array}$ & 0.295 & 0.760 & 1.133 & 0.872 & 0.038 & $\begin{array}{l}\text { arabinan catabolic process; regulation of meristem growth; response to } \\
\text { arsenic-containing substance; seed coat development; xylan catabolic } \\
\text { process }\end{array}$ & $\begin{array}{l}\text { apoplast;chloroplast;plant-type } \\
\text { cell wall;plasmodesma; vacuolar } \\
\text { membrane }\end{array}$ & $\begin{array}{l}\text { alpha-N-arabinofuranosidase } \\
\text { activity;yylan 1,4-beta- } \\
\text { xylosidase activity }\end{array}$ & \\
\hline 38 & SCCCRT1002G03.g & $\begin{array}{l}\text { Glycosyl hydrolase family } 3 \text { protein } \\
\text { (Xylosidase)(UNIPROT) }\end{array}$ & 0.525 & 0.748 & 1.179 & 1.136 & 0.009 & $\begin{array}{l}\text { arabinan catabolic process; response to chemical stimulus ; seed coat } \\
\text { development; xylan catabolic process }\end{array}$ & $\begin{array}{l}\text { apoplast;chloroplast;;plant-type } \\
\text { cell wall;plasmodesma;vacuolar } \\
\text { membrane }\end{array}$ & $\begin{array}{l}\text { alpha-N-arabinofuranosidase } \\
\text { activity;yylan 1,4-beta- } \\
\text { xylosidase activity }\end{array}$ & $\begin{array}{l}\text { beta-D-xylosidase } 4 \\
{[\text { [EC:3.2.2.1.37];XYL4 }}\end{array}$ \\
\hline 39 & SCCCSB1003H06.g & $\begin{array}{l}\text { Glycosyl hydrolase family } 3 \text { protein } \\
\text { (Xylosidase)(UNIPROT) }\end{array}$ & 0.395 & 1.276 & 0.995 & 1.138 & 0.001 & $\begin{array}{l}\text { arabinan catabolic process; regulation of meristem growth; response to } \\
\text { arsenic-containing substance; seed coat development; xylan catabolic } \\
\text { process }\end{array}$ & $\begin{array}{l}\text { apoplast;chloroplast;;lant-type } \\
\text { cell wall;plasmodesma;vacuolar } \\
\text { membrane }\end{array}$ & $\begin{array}{l}\text { alpha-N-arabinofuranosidase } \\
\text { activity;yylan 1,4-beta- } \\
\text { xylosidase activity }\end{array}$ & \\
\hline 40 & SCEZRZ3015A12.g & $\begin{array}{l}\text { Glycosyl hydrolase family } 3 \text { protein } \\
\text { (Xylosidase)(UNIPROT) }\end{array}$ & 0.410 & 1.249 & 0.945 & 1.091 & 0.001 & carbohydrate metabolic process & & $\begin{array}{l}\text { hydrolase activity, hydrolyzing } \\
\text { O-glycosyl compounds }\end{array}$ & $\begin{array}{l}\text { beta-D-Xylosidase } 4 \\
{[\mathrm{EC}: 3.2 .2 .1 .37] ; \times Y L 4}\end{array}$ \\
\hline 41 & SCEQLR1093F09.g & glycosyl hydrolase family 3 protein(UNIPROT) & 0.780 & 0.877 & 1.013 & 1.432 & 0.001 & carbohydrate metabolic process & & $\begin{array}{l}\text { hydrolase activity, hydrolyzing } \\
\text { O-glycosyl compounds }\end{array}$ & 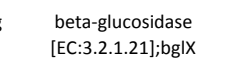 \\
\hline 42 & SCEZLB1007A09.g & glycosyl hydrolase family 3 protein(UNIPROT) & 0.728 & 1.014 & 0.765 & 0.892 & 0.500 & $\begin{array}{l}\text { carbohydrate metabolic process;cell wall organization or } \\
\text { biogenesis;cellular }\end{array}$ & $\begin{array}{l}\text { anchored to membrane; cytosol; } \\
\text { extracellular region; plant-type cell } \\
\text { wall; plasma membrane; } \\
\text { plasmodesma; vacuole }\end{array}$ & $\begin{array}{l}\text { xylan 1,4-beta-xylosidase } \\
\text { activity }\end{array}$ & $\begin{array}{l}\text { beta-glucosidase } \\
\text { [EC:3.2.1.21];bg|X }\end{array}$ \\
\hline 43 & SCCCCL2001B11.b & $\begin{array}{l}\text { Glycosyl hydrolases family } 18 \text { (probable chitinase } \\
\text { or xylanase inibitor)(UNIPROT) }\end{array}$ & 0.689 & 1.021 & 0.725 & 1.039 & 0.019 & carbohydrate metabolic process & & $\begin{array}{l}\text { hydrolase activity, hydrolyzing } \\
\text { O-glycosyl compounds }\end{array}$ & $\begin{array}{c}\text { chitinase } \\
{[\mathrm{EC}: 3.2 .1 .14] ; E 3.2 \cdot 1 \cdot 14}\end{array}$ \\
\hline 44 & ScCCCL4003F09.g & $\begin{array}{l}\text { Glycosyl hydrolases family } 18 \text { (probable chitinase } \\
\text { or xylanase inibitor)(UNIPROT) }\end{array}$ & 0.765 & 1.004 & 0.836 & 1.231 & 0.662 & $\begin{array}{l}\text { carbohydrate metabolic process;cellular process;response to abiotic } \\
\text { stimulus;rresponse to stress;single-organism process }\end{array}$ & & $\begin{array}{l}\text { hydrolase activity, hydrolyzing } \\
\text { O-glycosyl compounds }\end{array}$ & $\begin{array}{l}\text { chitinase } \\
\text { [EC:3.2.1.14]; } 33.2 \cdot 1 \cdot 14\end{array}$ \\
\hline 45 & SCLRT1020A08.g & $\begin{array}{l}\text { Probable alpha-glucosidase Os0650675700 } \\
\text { OS=Oryza sativa subsp. japonica } \\
G N=0 \text { S06g0675700 PE=1 SV=1 (UNIPROT) }\end{array}$ & 0.669 & 1.098 & 0.690 & 1.259 & 0.613 & $\begin{array}{l}\text { plant-type cell wall biogenesis; plant-type cell wall organization; xylan } \\
\text { catabolic process; ;yloglucan metabolic process }\end{array}$ & $\begin{array}{l}\text { apoplast; chloroplast; cytosol; } \\
\text { plant-type cell wall; plasmodesma; } \\
\text { vacuole }\end{array}$ & $\begin{array}{l}\text { alpha-N-arabinofuranosidase } \\
\text { activity;yxlan 1,4-beta- } \\
\text { xylosidase activity;yyloglucan } \\
1,6 \text {-alpha-xylosidase activity }\end{array}$ & $\begin{array}{l}\text { alpha-glucosidase } \\
\text { [EC:3.2.1.20];malz }\end{array}$ \\
\hline
\end{tabular}




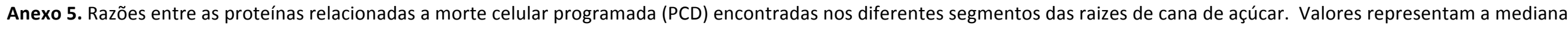

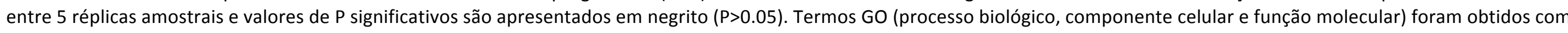
as ferramentas do software Blast2GO.

\begin{tabular}{|c|c|c|c|c|c|c|c|c|c|c|c|}
\hline & SAS - Sucest & Nome da proteína, espécie (banco de dados) & $\operatorname{seg} 1 / 2$ & $\begin{array}{l}\text { Mediana di } \\
\text { seg } 2 / 3\end{array}$ & $\begin{array}{l}\text { r razões } \\
\text { seg } 3 / 4\end{array}$ & $\operatorname{seg} 4 / 5$ & $\begin{array}{l}\text { ANOVA } \\
\text { P-value }\end{array}$ & GO processo biológico & GO componente celular & GO função molecular & informações do kegg \\
\hline 1 & SCACLR1057G08.g & $\begin{array}{l}\text { Activator of } 90 \text { kDa heat shock protein ATPase } \\
\text { homolog 1;AHA1(UNIPROT) }\end{array}$ & 1.448 & 0.777 & 1.707 & 0.613 & 0.012 & $\begin{array}{l}\text { protein folding; response to endoplasmic reticulum stress; response to } \\
\text { heat; response to high light intensity; response to hydrogen peroxide }\end{array}$ & cytosol; nucleus & $\begin{array}{l}\text { ATPase activator } \\
\text { activity; chaperone binding }\end{array}$ & \\
\hline 2 & SCRLRZ3042B09.g & $\begin{array}{l}\text { Aspartic proteinase nepenthesin-1 OS=Nepenthes } \\
\text { gracilis GN=nep1 PE=1 SV=1 (UNIPROT) }\end{array}$ & 1.977 & 0.969 & 0.920 & 1.307 & 0.006 & $\begin{array}{l}\text { cell wall modification; cellular metabolic process;defense response ; plant-type cell } \\
\text { wall organization;proteoolysis; regulation of cellular process; response to abscisic acid } \\
\text { stimulus; response to karrikin; response to other organism; response to water } \\
\text { deprivation }\end{array}$ & $\begin{array}{l}\text { endoplasmic reticulum; } \\
\text { extracellular region; membrane; } \\
\text { plant-type cell wall; plasmodesma }\end{array}$ & $\begin{array}{l}\text { aspartic-type endopeptidase } \\
\text { activity }\end{array}$ & \\
\hline 3 & SCCCLB1004B02.g & $\begin{array}{l}\text { ATP synthase subunit alpha, } \\
\text { mitochondrial(UNIPROT) }\end{array}$ & 0.383 & 0.887 & 1.351 & 1.386 & 0.002 & $\begin{array}{l}\text { ATP hydrolysis coupled proton transport; cell growth; cellulose metabolic process; } \\
\text { dATP biosynthetic process from ADP; defense response to bacterium; DNA- } \\
\text { dependent transcription, lolongation; plant-type cell wall biogenesis; response to } \\
\text { cold; response to oxidative stress }\end{array}$ & $\begin{array}{l}\text { cell wall; chloroplast ATP synthase } \\
\text { complex; Golgi apparatus; } \\
\text { mitcochondrial proton-transporting } \\
\text { ATP synthase complex; nucleolus; } \\
\text { plasma membrane; } ; \text {;TPase } \\
\text { complex, catalytic domain vacuolar } \\
\text { membrane }\end{array}$ & $\begin{array}{l}\text { ATP binding; cobalt ion binding; } \\
\text { copper ion binding; proton- } \\
\text { transporting ATP synthase } \\
\text { activity, rotational mechanism }\end{array}$ & $\begin{array}{l}\text { ATPeF1A;F-type H+- } \\
\text { transporting ATPase } \\
\text { subunit alpha }\end{array}$ \\
\hline 4 & sCCCRZ2001D06.g & $\begin{array}{l}\text { ATP synthase subunit beta, } \\
\text { mitochondrial;(UNIPROT) }\end{array}$ & 0.840 & 0.968 & 0.982 & 0.892 & 0.161 & 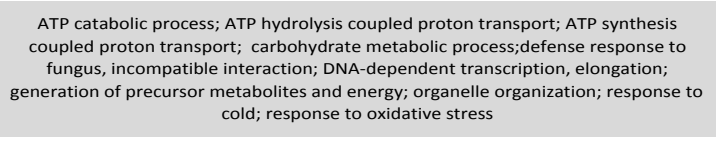 & $\begin{array}{l}\text { cell wall; chloroplast ATP synthase } \\
\text { comple; cytosol;Golgi apparatus; } \\
\text { mitochondrial respiratory chain } \\
\text { complex I; nucleolus; plasma } \\
\text { membrane; vacuolar membrane }\end{array}$ & $\begin{array}{l}\text { ATP binding; cobalt ion } \\
\text { binding;copper ion binding; } \\
\text { poly(U) RNA binding;proton- } \\
\text { transporting ATP synthase } \\
\text { activity, rotational mechanism; } \\
\text { zinc ion binding }\end{array}$ & $\begin{array}{l}\text { ATPeF1B;F-type H+- } \\
\text { transporting ATPase } \\
\text { subunit beta } \\
\text { [EC:3.6.3.14] }\end{array}$ \\
\hline 5 & ScCCCL4015F12.g & $\begin{array}{l}\text { Basic } 75 \text { globulin;:SBg 75;Bg;:Basic 7S globulin high } \\
\text { kDa subunitibasic 7s globulin low kDa } \\
\text { subunit;;(UNIPRRT) }\end{array}$ & 0.567 & 0.698 & 0.841 & 0.967 & 0.765 & proteolysis & cell periphery & $\begin{array}{l}\text { aspartic-type endopeptidase } \\
\text { activity }\end{array}$ & \\
\hline 6 & SCAGLB2046F01.g & $\begin{array}{l}\text { Bowman-Birk type bran trypsin inhibitor precursor } \\
\text { (Protein RBB13-3) (RBTI) (OSE727A)(UNIPROT) }\end{array}$ & 0.239 & 0.637 & 1.248 & 1.406 & 0.000 & & extracellular region & $\begin{array}{l}\text { serine-type endopeptidase } \\
\text { inhibitor activity }\end{array}$ & \\
\hline 7 & scCCCL2001B01.b & calmodulin-binding protein(UNIPROT) & 0.465 & 0.978 & 0.791 & 1.062 & 0.000 & $\begin{array}{l}\text { cellular component organization or biogenesisis--xylose metabolic process;pollen } \\
\text { germination;single-organism cellular process }\end{array}$ & $\begin{array}{l}\text { endosome; extracelllular space; } \\
\text { Golgi apparatus; integral to } \\
\text { membrane ; ;lasma membrane; } \\
\text { trans-Golgi network }\end{array}$ & 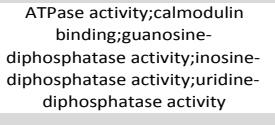 & $\begin{array}{l}\text { APY1_2;apyrase } \\
\text { [EC:3.6.1.5] }\end{array}$ \\
\hline 8 & SCVPLR1049C09.g & calmodulin-binding protein(UNIPROT) & 3.217 & 0.969 & 1.575 & 0.767 & 0.000 & 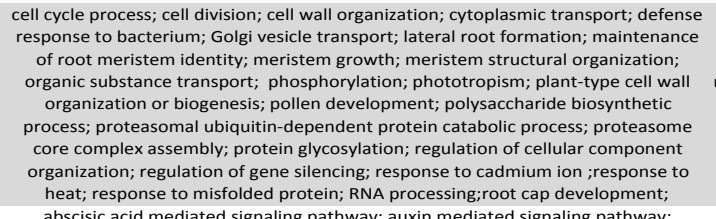 & $\begin{array}{l}\text { apoplast; cell wall; chloroplast } \\
\text { thylakoid membrane; cytosolic } \\
\text { ribosome; Golgi apparatusts nuclear } \\
\text { envelope; nucleolus; } \\
\text { plasmodesma; proteasome } \\
\text { regulatory particle, base } \\
\text { subcomplex ; spindle }\end{array}$ & $\begin{array}{l}\text { ATP binding;ATPase } \\
\text { activity;calmodulin } \\
\text { binding;identical protein } \\
\text { binding }\end{array}$ & $\begin{array}{l}\text { transitional } \\
\text { endoplasmic reticulum } \\
\text { ATPase; ;CP }\end{array}$ \\
\hline 9 & SCCCLR1070F12.g & calnexin(UNIPROT) & 1.254 & 0.989 & 1.084 & 0.979 & 0.902 & 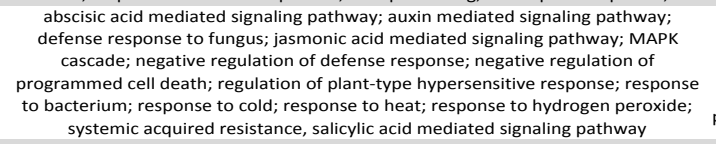 & $\begin{array}{l}\text { chloroplast; cytosol; endoplasmic } \\
\text { reticulum; Golgi apparatus; } \\
\text { mitochondrion; plant-type cell } \\
\text { wall; plasma membrane; } \\
\text { plasmodesma; vacuolar membrane }\end{array}$ & $\begin{array}{l}\text { calcium ion } \\
\text { binding; molybdenum ion } \\
\text { binding;unfolded protein } \\
\text { binding }\end{array}$ & calnexin;CANX \\
\hline 10 & SCSGST1072D03.g & $\begin{array}{l}\text { Calreticulin OS=Oryza sativa subsp. japonica } \\
\text { GN=OS07g0246200 PE=1 SV=2 (UNIPROT) }\end{array}$ & 3.429 & 1.193 & 1.144 & 0.797 & 0.000 & $\begin{array}{l}\text { auxin mediated signaling pathway; calcium ion homeostasis ; cellular response to } \\
\text { nitrogen statrvation; defenses response signaling pathway, resistance gene- } \\
\text { independent; defense response to bacterium; plant-type hypersensitive response; } \\
\text { response to cadmium ion; response to heat; response to hydrogen peroxide; } \\
\text { response to salt stress; salicylic acid biosynthetic process; systemic acquired } \\
\text { resistance }\end{array}$ & $\begin{array}{l}\text { apoplast; chloroplast; cytosol; } \\
\text { endoplasmic reticulum membrane; } \\
\text { Golgi ipparatus, mitochondrion; } \\
\text { plant-type eell wall, ;lasma ; } \\
\text { membrane; plasmodesma; } \\
\text { vacuolar membrane }\end{array}$ & $\begin{array}{l}\text { calcium ion } \\
\text { binding;molybdenum ion } \\
\text { binding;unfolded protein } \\
\text { binding }\end{array}$ & CALR;calreticulin \\
\hline 11 & SCEPLR1051D05.g & calreticulin(UNIPROT) & 2.957 & 1.008 & 1.395 & 0.865 & 0.000 & $\begin{array}{l}\text { auxin mediated signaling pathway; calcium ion homeostasis ; cellulalar response to } \\
\text { nitrogen starvation; defefnse response signaling pathway, resistance gene- } \\
\text { independent; defense response to bacterium; plant-type hypersensitive response; } \\
\text { response to cadmium ion; response to heat; response to hydrogen peroxide; } \\
\text { response to salt stress; salicylic acid biosynthetic process; systemic acquired } \\
\text { resistance }\end{array}$ & $\begin{array}{l}\text { apoplast; chloroplast; cytosol; } \\
\text { endoplassic reticulum membrane; } \\
\text { Golgi apparatus; mitochondrion; } \\
\text { plant-type cell walli, plassaa } \\
\text { membrane; plasmodesma; } \\
\text { vacuolar membrane }\end{array}$ & $\begin{array}{l}\text { calcium ion } \\
\text { binding; molybdenum ion } \\
\text { binding;infolded protein } \\
\text { binding }\end{array}$ & CALR;calreticulin \\
\hline 12 & SCCCLR1048HO9.g & $\begin{array}{l}\text { Catalase isozyme } 3 \text { OS=Zea mays GN=CAT3 PE=2 } \\
\text { SV=2 (UNIPROT) }\end{array}$ & 1.094 & 0.539 & 0.747 & 0.653 & 0.191 & 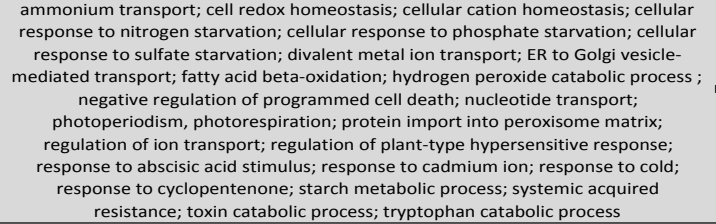 & $\begin{array}{l}\text { apoplast; cell wall; cytosolic } \\
\text { ribosome mitochondrion; nucleus; } \\
\text { peroxisome p plant-type vacuuole } \\
\text { membrane plasma membrane; } \\
\text { plasmodesma }\end{array}$ & $\begin{array}{l}\text { arginine transmemembane } \\
\text { transporter activity;catalase } \\
\text { activity;cationic amino acid } \\
\text { transmembrane transporter } \\
\text { activity; cobalt ion } \\
\text { binding;heme binding;- } \\
\text { glutamate transmembrane } \\
\text { transporter activity;:-lysine } \\
\text { transmembrane transporter } \\
\text { activity; protein binding }\end{array}$ & $\begin{array}{l}\text { catalase } \\
{[\mathrm{EC}: 1.11 .1 .6] \text {; katE }}\end{array}$ \\
\hline
\end{tabular}




\section{Continuação Anexo 5.}

\begin{tabular}{|c|c|c|c|c|c|c|c|c|c|c|c|}
\hline & SAS - Sucest & Nome da proteína, espécie (banco de dados) & $\begin{array}{r}\text { Medi } \\
\operatorname{seg} 1 / 2\end{array}$ & $\begin{array}{l}\text { a da Razẫ } \\
\operatorname{seg} 2 / 3\end{array}$ & $\begin{array}{l}\text { dos segm } \\
\text { seg } 3 / 4\end{array}$ & $\begin{array}{l}\text { intos } \\
\text { seg } 4 / 5\end{array}$ & $\begin{array}{l}\text { ANOVA } \\
\text { P-value }\end{array}$ & GO processo biológico & GO componente celular & GO função molecular & informações do kegg \\
\hline 13 & 3 SCCCLB1023F09.g & Cathepsin B (Fragment)(UNIPROT) & 0.372 & 0.983 & 0.780 & 0.874 & 0.000 & $\begin{array}{l}\text { cell growth; cell morphogenesis; ;fatty acid beta-oxidation; Golgi vesicle transport; } \\
\text { proteolysis; regulation of catalytic activity; response to abiotic stimulus; response to } \\
\text { inorganic substance; response to oxygen-containing compound ;response to stress }\end{array}$ & $\begin{array}{l}\text { cytosol; extracellular region; } \\
\text { vacuole }\end{array}$ & $\begin{array}{l}\text { cysteine-type endopeptidase } \\
\text { activity }\end{array}$ & $\begin{array}{l}\text { cathepsin B } \\
{[\mathrm{EC}: 3.3 .22 .1] ; \text { CTSB }}\end{array}$ \\
\hline 14 & 4 SCEQRT1025E03.g & $\begin{array}{l}\text { Cystatin-1 precursor (Cystatin I) (Corn kernel } \\
\text { cysteine proteinase inhibitor)(UNIPROT) }\end{array}$ & 0.730 & 1.534 & 1.226 & 0.763 & 0.546 & $\begin{array}{l}\text { cellular response to cold; cellular response to heat; cellular response to water } \\
\text { deprivation; hyperosmotic response; response to cadmium ion; response to } \\
\text { oxidative stress; response to wounding }\end{array}$ & $\begin{array}{l}\text { cell wall; cytosol; endoplasmic } \\
\text { reticulum; extracellular region; } \\
\text { plasma membrane; plasmodesma; } \\
\text { vacuolar membrane }\end{array}$ & $\begin{array}{l}\text { cobalt ion binding;cysteine- } \\
\text { type endopeptidase inhibitor } \\
\text { activity }\end{array}$ & \\
\hline 15 & 5 SCCCLR1022B11.g & cysteine protease 1 precursor [Zea mays](NCBI) & 0.442 & 0.952 & 0.810 & 0.936 & 0.083 & $\begin{array}{l}\text { cell wall pectin metabolic process; cysteine biosynthetic process; defense response } \\
\text { to fungus, incompatible interaction; developmental programmed cell death; } \\
\text { gibberellic acid mediated signaling pathway; gibberellin biosynthetic process } \\
\text {;glucuronoxylan metabolic process; Golgi organization; hydrogen peroxide catabolic } \\
\text { process; hyperosmotic salinity response ;leaf senescence; plant-type cell wall } \\
\text { cellllose metabolic processs; proteolysis; regulation of meristem growth; response to } \\
\text { cadmium ion; response to ethylene stimulus; response to water deprivation; root } \\
\text { hair elongation; water transport; xylan biosynthetic process }\end{array}$ & $\begin{array}{l}\text { anchored to membrane; apoplast; } \\
\text { cell wall; chloroplast; cytosol; } \\
\text { endoplasmic reticulum; nucleus; } \\
\text { plasmodesma; senescence- } \\
\text { associated vacuole }\end{array}$ & $\begin{array}{l}\text { calcium ion binding; cysteine- } \\
\text { type peptidase activity; protein } \\
\text { binding }\end{array}$ & \\
\hline 16 & 6 SCCCRZ2001D03.g & $\begin{array}{c}\text { Cysteine proteinase } 2 \text { OS=Zea mays } \mathrm{GN}=\mathrm{CCP} 2 \mathrm{PE}=2 \\
\mathrm{SV}=1 \text { (UNIPROT) }\end{array}$ & 0.405 & 0.933 & 0.865 & 1.031 & 0.075 & $\begin{array}{l}\text { calcium ion transport; cell wall polyyaccharide metabolic process; cellular } \\
\text { biosynthetic process; defense response to fungus; Golgi organization; hydrogen } \\
\text { peroxide catabolic process; hyperosmotic salinity response; organ development; } \\
\text { organic substance biosynthetic process; proteolysis; response to cadmium ion; } \\
\text { response to ethylene stimulus; response to fructose stimulus; response to } \\
\text { gibberellin stimulus; water transport }\end{array}$ & $\begin{array}{l}\text { apoplast; cell wall; chloroplast; } \\
\text { cytosol; endoplasmic reticulum; } \\
\text { plant-type vacuole; plasmodesma }\end{array}$ & $\begin{array}{l}\text { calcium ion binding;cysteine- } \\
\text { type peptidase activity; protein } \\
\text { binding }\end{array}$ & $\begin{array}{c}\text { cathepsin } \mathrm{H} \\
{[\mathrm{EC}: 3.4 .22 .16] ; \mathrm{CTSH}}\end{array}$ \\
\hline 17 & 7 SCCCRZ3002G10.g & $\begin{array}{l}\text { Cysteine proteinase inhibitor } 8 \text { OS=Oryza sativa } \\
\text { subsp. japonica GN=Os03g0429000 PE=2 SV=1 } \\
\text { (UNIPROT) }\end{array}$ & 0.783 & 0.491 & 0.739 & 0.889 & 0.000 & $\begin{array}{l}\text { cellular response to stress; response to inorganic substance; response to } \\
\text { temperature stimulus }\end{array}$ & $\begin{array}{l}\text { cell wall; cytosol; membrane; } \\
\text { plasmodesma; vacuole }\end{array}$ & $\begin{array}{l}\text { cysteine-type endopeptidase } \\
\text { inhibitor activity }\end{array}$ & \\
\hline 18 & 8 SCCCLR1001H04.g & $\begin{array}{l}\text { Cytochrome b-c1 complex subunit 7;Ubiquinol- } \\
\text { cytochrome c reductase complex } 14 \text { kDa } \\
\text { protein;Complex III subunit 7; Complex III subunit } \\
\text { VII;CR14(UNIPROT) }\end{array}$ & 0.403 & 1.200 & 1.389 & 1.252 & 0.007 & $\begin{array}{l}\text { aerobic respiration; glycolysis; mitochondrial electron transport, ubiquinol to } \\
\text { cytochrome c; photorespiration; proteasome core complex assembly; response to } \\
\text { cadmium ion; response to misfolded protein; ubiquititin-dependent protein catabolic } \\
\text { process }\end{array}$ & $\begin{array}{l}\text { mitochondrial respiratory chain } \\
\text { complex III; plastid; vacuolar } \\
\text { membrane }\end{array}$ & $\begin{array}{l}\text { ubiquinol-cytochrome-c } \\
\text { reductase activity }\end{array}$ & $\begin{array}{l}\text { QCR7; ubiquinol- } \\
\text { cytochrome c } \\
\text { reductase subunit } 7\end{array}$ \\
\hline 19 & 9 SCQGLR2025G04.g & Cytochrome b5(UNIPROT) & 1.046 & 1.360 & 1.224 & 0.909 & 0.534 & $\begin{array}{l}\text { alkane biosynthetic process; cellular lipid catabolic process; defense response to } \\
\text { bacterium; glucosinolate biosynthetic process; indoleacetic acid biosynthetic } \\
\text { process; lateral root formation; nitrate assimilation; nitric oxide biosynthetic } \\
\text { process; response to symbiotic fungus; root hair elongation; sterol biosynthetic } \\
\text { process }\end{array}$ & $\begin{array}{l}\text { chloroplast outer membrane; } \\
\text { chloroplast thylakoid membrane; } \\
\text { cytosol; endoplasmic reticulum } \\
\text { membrane; mitochondrion; plasma } \\
\text { membrane ; vacuolar membrane }\end{array}$ & $\begin{array}{l}\text { heme binding;nitrate reductase } \\
\text { (NADH) activity; protein } \\
\text { binding;sphingolipid delta-8 } \\
\text { desaturase activity }\end{array}$ & \\
\hline 20 & 0 SCUTLR2023F06.g & $\begin{array}{l}\text { Cytochrome c OS=Oryza sativa subsp. japonica } \\
\text { GN=CC-1 PE=1 SV=1 (UNIPROT) }\end{array}$ & 2.783 & 1.101 & 0.644 & 0.812 & 0.072 & cell proliferation; glucose catabolic process & $\begin{array}{l}\text { cytosol; Golgi apparatus; } \\
\text { mitochondrion; vacuolar } \\
\text { membrane }\end{array}$ & $\begin{array}{l}\text { copper ion binding; electron } \\
\text { carrier activity; heme binding; } \\
\text { iron ion binding }\end{array}$ & Crc;cytochrome c \\
\hline 21 & 1 SCCCLR1080A05.g & $\begin{array}{l}\text { Cytochrome coxidase subunit } 6 \mathrm{~B} \\
\text { OS=Schizosaccharomyces pombe } \mathrm{GN}=\operatorname{cox} 12 \mathrm{PE}=2 \\
\text { SV=2 (UNIPROT) }\end{array}$ & 1.748 & 0.000 & 0.000 & 0.000 & 0.184 & $\begin{array}{l}\text { oxidation-reduction process; phosphatidylinositol biosynthetic process; } \\
\text { photorespiration; response to salt stress }\end{array}$ & $\begin{array}{l}\text { chloroplast thylakoid membrane; } \\
\text { mitochondrion }\end{array}$ & $\begin{array}{l}\text { copper ion binding; cytochrome- } \\
\text { coxidase activity }\end{array}$ & \\
\hline 22 & 2 SCUTLR1058A12.g & $\begin{array}{l}\text { Cytochrome c1-1, heme protein, } \\
\text { mitochondrial;Ubiquinol-cytochrome-c reductase } \\
\text { complex cytochrome c1 subunit 1;Cytochrome c-1- } \\
\text { 1;Cytochrome b-c1 complex subunit 4-1;Complex } \\
\text { III subunit 4-1;Complex III subunit IV-1;(UNIPROT) }\end{array}$ & 0.260 & 0.993 & 0.959 & 1.304 & 0.001 & $\begin{array}{l}\text { aerobic respiration; pentose-phosphate shunt; ;photorespiration; proteasome core } \\
\text { complex assembly; response to cadmium ion; response to misfolded protein; } \\
\text { response to salt stress; ubiquititn-dependent protein catabolic process }\end{array}$ & $\begin{array}{l}\text { mitochondrial respiratory chain } \\
\text { complex III; plasma membrane; } \\
\text { vacuolar membrane }\end{array}$ & $\begin{array}{l}\text { electron transporter, } \\
\text { transferring electrons within } \\
\text { CoQH2-cytochrome c reductase } \\
\text { complex activity; heme binding; } \\
\text { iron ion binding; protein } \\
\text { binding }\end{array}$ & $\begin{array}{l}\text { CYC1; ubiquinol- } \\
\text { cytochrome c } \\
\text { reductase cytochrome } \\
\text { c1 subunit }\end{array}$ \\
\hline & 3 SCJFLR1013A09.g & drought and cold response(UNIPROT) & 1.683 & 0.529 & 0.962 & 1.139 & 0.211 & $\begin{array}{l}\text { cell development; cell wall organization or biogenesis; defense response to } \\
\text { bacterium; Golgi organization; hydrogen peroxide catabolic process; hyperosmotic } \\
\text { salinity response; organ development; organic substance biosynthetic process; } \\
\text { polysaccharide metabolic process; proteolysis; response to cadmium ion; response } \\
\text { to desiccation; resposonse to hormone stimulussing; water transport }\end{array}$ & $\begin{array}{l}\text { apoplast; cell wall; cytosol; } \\
\text { endoplasmic reticulum; nucleus; } \\
\text { vacuole }\end{array}$ & $\begin{array}{l}\text { calcium ion binding;cysteine- } \\
\text { type endopeptidase activity; } \\
\text { protein binding }\end{array}$ & $\begin{array}{l}\text { cathepsin } F \\
{[\text { [EC:3.4.22.41];CTSF }}\end{array}$ \\
\hline & 4 SCJFLR1073H09.g & enolase 1 [Zea mays](NCBI) & 0.901 & 0.977 & 1.217 & 0.901 & 0.074 & $\begin{array}{l}\text { gluconeogenesis; glycolysis; pentose-phosphate shunt; photorespiration; response } \\
\text { to abscisic acid stimulus; response to cadmium ion; response to cold; response to } \\
\text { light stimulus; response to salt stress; trichome morphogenesis }\end{array}$ & $\begin{array}{l}\text { apoplast; chloroplast stroma } \\
\text {;mitochondrial envelope; nucleus; } \\
\text { phosphopyruvate hydratase } \\
\text { complex; plasma membrane; } \\
\text { plasmodesma }\end{array}$ & $\begin{array}{l}\text { copper ion binding;DNA } \\
\text { binding;magnesium ion } \\
\text { binding;phosphopyruvate } \\
\text { hydratase activity }\end{array}$ & $\begin{array}{l}\text { ENO;enolase } \\
\text { [EC:4.2.1.11] }\end{array}$ \\
\hline
\end{tabular}


Continuação Anexo 5.

\begin{tabular}{|c|c|c|c|c|c|c|c|c|c|c|}
\hline SAS - Sucest & Nome da proteína, espécie (banco de dados) & $\begin{array}{l}\text { Media } \\
\text { seg } 1 / 2\end{array}$ & $\begin{array}{l}\text { la da Razão } \\
\text { seg } 2 / 3\end{array}$ & $\begin{array}{l}\text { dos segme } \\
\text { seg } 3 / 4\end{array}$ & $\begin{array}{l}\text { ntos } \\
\text { seg } 4 / 5\end{array}$ & $\begin{array}{l}\text { ANOVA } \\
P \text {-value }\end{array}$ & GO processo biológico & GO componente celular & GO função molecular & informações do kegg \\
\hline 25 SCCCRZ1002F06.g & $\begin{array}{l}\text { Enolase } 2 \text { OS=Zea mays GN=ENO2 PE=2 SV=1 } \\
\text { (UNIPROT) }\end{array}$ & 1.009 & 0.939 & 1.067 & 0.947 & 0.424 & $\begin{array}{l}\text { gluconeogenesis; glycolysis; pentose-phosphate shunt; photorespiration; response } \\
\text { to abscisic acid stimulus; response to cadmium ion; response to cold; response to } \\
\text { light stimulus; response to salt stress; trichome morphogenesis }\end{array}$ & $\begin{array}{l}\text { apoplast; chloroplast stroma; } \\
\text { mitochondrial envelope; nucleus; } \\
\text { phosphopyruvate hydratase } \\
\text { complex; plasma membrane; } \\
\text { plasmodesma }\end{array}$ & $\begin{array}{c}\text { copper ion binding;:DNA } \\
\text { binding;magnesium ion } \\
\text { binding;phosphopyruvate } \\
\text { hydratase activity }\end{array}$ & $\begin{array}{l}\text { ENO;enolase } \\
\text { [EC:4.2.1.11] }\end{array}$ \\
\hline 26 SCCCLR1070G05.g & $\begin{array}{l}\text { Enolase-phosphatase E1 (2,3-diketo-5-methylthio- } \\
\text { 1-phosphopentane hhosphatase) (MASA } \\
\text { homolog)(UNIPROT) }\end{array}$ & 0.852 & 0.898 & 0.978 & 1.020 & 0.087 & L-methionine salvage from methylthioadenosine & chloroplast stroma; cytosol & $\begin{array}{l}\text { acireductone synthase activity; } \\
\text { magnesium ion binding }\end{array}$ & $\begin{array}{l}\text { DEP1; methylthioribulo } \\
\text { se 1-phosphate } \\
\text { dehydratase / enolase- } \\
\text { phosphatase E1 } \\
\text { [EC:4.2.1.109 3.1.3.77] }\end{array}$ \\
\hline 27 SCCCRT1C01G07.g & $\begin{array}{l}\text { Germin-like protein } 8-5 \text { OS=Oryza sativa subsp. } \\
\text { japonica GN=OSOSg0189400 PE=2 SV=1 (UNIPROT) }\end{array}$ & 0.215 & 0.471 & 0.661 & 1.019 & 0.015 & $\begin{array}{l}\text { amino acid import; ER to Golgi vesicle-mediated transport; GDP-L-ffucose } \\
\text { biosynthetic processs; ; lucurononoxylan metabolic rrocesss; nitrate transport; } \\
\text { regulation of root development; response to cold; response to endoplasmic } \\
\text { reticulum stress; response to nitrate ;response to salt stres; xylan biosynthetic } \\
\text { process }\end{array}$ & $\begin{array}{l}\text { apoplast:extracelllular } \\
\text { matrixinucleus;plant-type cell } \\
\text { wall,plant-type vacuole plasma } \\
\text { membrane; }\end{array}$ & $\begin{array}{c}\text { manganese ion } \\
\text { binding;nutrient reservoir } \\
\text { activity;oxalate oxidase activity }\end{array}$ & \\
\hline 28 SCCCRZ1002G01.g & $\begin{array}{l}\text { Heat shock cognate } 70 \text { kDa protein } 2 \text { OS=Solanum } \\
\text { Iycopersicum GN=HSC-2 PE=2 SV=1 (UNIPROT) }\end{array}$ & 1.332 & 0.834 & 1.386 & 0.868 & 0.260 & $\begin{array}{l}\text { autophagy; defense response to bacterium; defense response to fungus; } \\
\text { endoplasmic reticulum unfolded protein response; ER-associated protein catabolic } \\
\text { process; gluconeogenesis; heat acclimation ;hyperosmotic salinity response } \\
\text {;negative regulation of seed germination; ; rotein retention in RR lumen; protein } \\
\text { targeting to chloroplast; response to cadmium ion; response to cold; response to } \\
\text { high light intensity; response to hydrogen peroxide; response to virus; response to } \\
\text { water deprivation; salicylic acid biosynthetic process; systemic acquired resistance }\end{array}$ & $\begin{array}{l}\text { apoplast; cell wall; chloroplast } \\
\text { envelope, cisi-Golgi network; } \\
\text { cytosolic ribosome; endoplasmic } \\
\text { reticulum lumen; Golgi apparatus } \\
\text {;integral to membrane; mediator } \\
\text { complex; mitochondrial matrix; } \\
\text { nuclear matrix; nucleolus; plasma } \\
\text { membrane; plasmodesma; } \\
\text { thylakoid;ivacuolar membrane }\end{array}$ & $\begin{array}{l}\text { ATP binding;:KDEL sequence } \\
\text { binding,protease } \\
\text { binding;receptor } \\
\text { activity;ubiquitin protein ligase } \\
\text { binding;zinc ion binding }\end{array}$ & $\begin{array}{l}\text { heat shock 70kDa } \\
\text { protein } 1 / 8 ; \text { HSPA1_8 }\end{array}$ \\
\hline 29 SCJLLR1011E03.g & $\begin{array}{l}\text { Heat shock protein } 81-1 \text { OS=Oryza sativa subsp. } \\
\text { japonica GN=HPS1-1 PE=2 SV=2 (UNIPROT) }\end{array}$ & 1.229 & 0.939 & 1.253 & 1.009 & 0.856 & $\begin{array}{l}\text { calcium-mediated signaling; cellular response to calcium ion; de-etiolation; defense } \\
\text { response to bacterium, incompatible interaction; heat acclimation; rrganic } \\
\text { substance biossnthetici processs; protein secretion, protein stabilizization; regulation of } \\
\text { meristem growth; regulation of meristem structural organization; response to } \\
\text { cadmium ion; response to chlorate;response to cold; response to hydrogen } \\
\text { peroxide; response to mechanical stimulus; response to salt stress; response to } \\
\text { water deprivation }\end{array}$ & 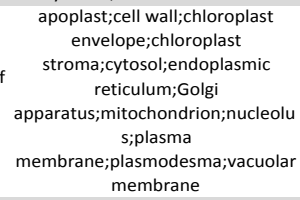 & $\begin{array}{l}\text { ATP binding; ATPase } \\
\text { activity;unfolded protein } \\
\text { binding }\end{array}$ & $\begin{array}{l}\text { htpG;molecular } \\
\text { chaperone HtpG }\end{array}$ \\
\hline 30 SCCCLR2C02F10.g & $\begin{array}{l}\text { Heat shock protein 81-3 OS=Oryza sativa subsp. } \\
\text { japonica GN=HSP81-3 PE=2 SV=2 (UNIPROT) }\end{array}$ & 4.972 & 0.839 & 1.613 & 0.694 & 0.003 & $\begin{array}{l}\text { calcium-mediated signaling; cellular response to calcium ion; de-etiolation; defense } \\
\text { response to bacterium, incompatible interaction; heat acclimation; rrganic } \\
\text { substance biosynthetici processs; protein secretion, protein stabilizization; regulation of } \\
\text { meristem growth; regulation of meristem structural organization; response to } \\
\text { cadmium ion; response to chlorate;response to cold; response to hydrogen } \\
\text { peroxide; response to mechanical stimulus; response to salt stress; response to } \\
\text { water deprivation }\end{array}$ & 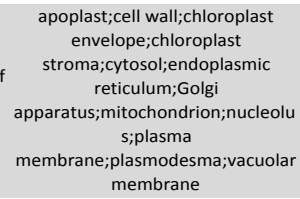 & $\begin{array}{l}\text { ATP binding;ATPase } \\
\text { activity;unfolded protein } \\
\text { binding }\end{array}$ & $\begin{array}{l}\text { htpG;molecular } \\
\text { chaperone HtpG }\end{array}$ \\
\hline 31 SCBGRT3075F07.g & Jasmonate(UNIPROT) & 0.923 & 1.056 & 0.950 & 0.716 & 0.042 & $\begin{array}{l}\text { jasmonic acid biosynthetic process; leaf senescence; oxidation-reduction process; } \\
\text { oxylipin metabolic process ; response to cadmium ion; response to fungus;response } \\
\text { to hormone stimulus; response to ozone; response to salicylic acid stimulus; } \\
\text { response to wounding; signal transduction }\end{array}$ & cytosol;peroxisome & $\begin{array}{l}\text { 12-oxophytodienoate } \\
\text { reductase activity;FMN binding }\end{array}$ & $\begin{array}{c}\text { 12-oxophytodienoic } \\
\text { acid reductase } \\
\text { [EC:1.3.1.42];E1.3.1.42 }\end{array}$ \\
\hline 32 SCJLRZ1024A04.g & Jasmonate(UNIPROT) & 0.372 & 0.841 & 1.099 & 1.106 & 0.000 & $\begin{array}{l}\text { anther dehiscence; cellular amino acid metabolic process ; cellular aromatic } \\
\text { compound metabolic process; coenzyme metabolic process; defense response to } \\
\text { bacterium, incompatible interaction; growth; jasmonic acid biosynthetic processs } \\
\text {;lateral root formation; ;ipid biosynthetic process; lipid oxidation; localization; } \\
\text { membrane disassembly; negative regulation of defense response to insect; organic } \\
\text { cyclic compound metabolic process; response to abscisic acid stimulus; response to } \\
\text { fungus;response to herbivore; response to jasmonic acid stimulus; response to } \\
\text { ozone; response to water deprivation ;response to wounding }\end{array}$ & $\begin{array}{l}\text { chloroplast envelope;chloroplast } \\
\text { stroma;chloroplast thylakoid } \\
\text { membrane;plasma membrane }\end{array}$ & $\begin{array}{l}\text { iron ion binding;linoleate 135- } \\
\text { lipoxygenase activity:linoleate } \\
\text { 95-lipoxygenase activity;protein } \\
\text { binding }\end{array}$ & $\begin{array}{c}\text { linoleate 9S- } \\
\text { lipoxygenase } \\
\text { [EC:1.13.11.58]; LOX1_ } \\
5\end{array}$ \\
\hline 33 sccCCL4013D09.g & jasmonic acid(UNIPROT) & 0.937 & 1.080 & 1.210 & 0.939 & 0.579 & 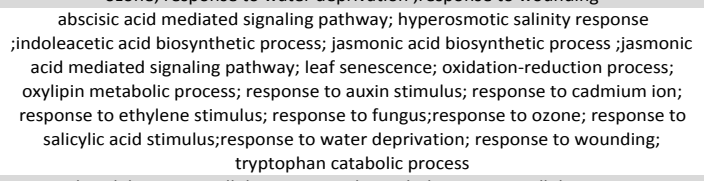 & cytosol;peroxisome & $\begin{array}{l}\text { 12-oxophytodienoate } \\
\text { reductase activity;FMN binding }\end{array}$ & $\begin{array}{c}\text { 12-oxophytodienoic } \\
\text { acid reductase } \\
\text { [EC:1.3.1.42]; E1.3.1.4. }\end{array}$ \\
\hline 34 SCCCRT1001E01.g & jasmonic acid(UNIPROT) & 0.756 & 1.107 & 1.413 & 1.246 & 0.000 & $\begin{array}{l}\text { anther dehiscence; cellular amino acid metabolic process ; cellular aromatic } \\
\text { compound metabolic process; coenzyme metabolic process; defense response to } \\
\text { bacterium, incompatible interaction; growth; jasmonic acid biosynthetic process } \\
\text {;lateral root formation; ilipid biosynthetic process; lipid oxidation; localization; } \\
\text { membrane disassembly; negative regulation of defense response to insect; organic } \\
\text { cyclic compound metabolic process; response to abscisic acid stimulus; response to } \\
\text { fungus;;response to herbivore; response to jasmonic acid stimulusu; response to } \\
\text { ozone; response to water deprivation ; response to wounding }\end{array}$ & $\begin{array}{l}\text { chloroplast envelope; chloroplast } \\
\text { stroma;chloroplast thylakoid } \\
\text { membrane }\end{array}$ & $\begin{array}{l}\text { iron ion binding;:linoleate 135- } \\
\text { lipoxygenase activity;linoleate } \\
\text { 9S-lipoxygenase activity;protein } \\
\text { binding }\end{array}$ & $\begin{array}{c}\text { linoleate 9S- } \\
\text { lipoxygenase } \\
{[\text { [EC:1.13.11.58];LOX1_ }} \\
5\end{array}$ \\
\hline
\end{tabular}




\section{Continuação Anexo 5.}

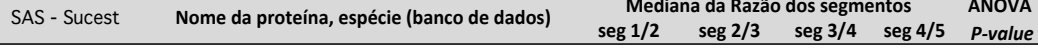

asmonic acid(UNIPROT

$1.198 \quad 1.264$

$1.291 \quad 1.207$

0.000

$37 \begin{aligned} & \text { L-ascorbate peroxidase 1, cytosolic OS=Oryza } \\ & \text { SCAtiva subsp. japonica GN=APX1 PE=1 SV }=1\end{aligned}$

$$
\text { (UNIPROT) }
$$

.527

0.932

.773

0.967

$1.407 \quad 0.06$

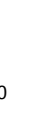
anther dehiscence; cellular amino acid metabolic process; ;ellular aromatic compound metabolic process; coenzyme metabolic process; defense response to incterium, incompatible interaction; growth; jasmonic acid biosynthetic process membrane disassembly; negative regulation of defense response to insect; organic cyclic compound metabolic process; response to abscisic acid stimulus; response to fungus; response to herbivore; response to jasmonic acid stimulus; response to compound metabolic process; coenzyme metabolic process; defense response to bacterium, incompatible interaction; growth; jasmonic acid biosynthetic process ;Iateral root formation ;lipid biosynthetic process; lipid oxidation; localization; membrane disassembly; negative regulation of defense response to insect; organic funcosirespons to horbivo; response to josmonic acid stimulus; response to development ending in seed dormancy; Golgi organization; hydrogen peroxide rabolic process, hydrogen peroxide mediated signaling pathway, hyperosmotic catabolic process; response to cadmium ion; response to endoplasmic reticulum stress: response to heat; response to salt stress:

cell communication; cell wall polysaccharide catabolic process; cellular response to stimulus ; defense response to fungus; defense response to nematode; hyperosmotic 38 SCBFRZ2017C11.g peroxidase(UNIPROT)

process; plant-type cell wall organization; regulation of cellular process; respiratory burst; response to cold; response to desiccation; response to organic substance;

anion transport; cell communication; cell wall polysaccharide catabolic process; cellular response to hypoxia; defense response to fungus; defense response to nematode, hyperosmotic salinity response, ilgnin biosynthetic process; mucilage extrusion from seed coat; nitrogen compound transport; organic substance
39 SCCCAD1001C08.g
peroxidase(UNIPROT)
0.209
0.536
0.919
$1.043 \quad 0.000$
nsport; oxidation-reduction process; plant-type cell wall organization; regulation response to oxidative stress; transition metal ion transport response;ion transport; lignin biosynthetic process; organ development: oxidation40 SCCCCL3002E11.b peroxidase(UNIPROT)

reduction process; primary metabolic process; regulation of cellular process; respiratory burst; response to cold; response to desiccation; response to organic
substance; response to oxidative stress; single-organism developmental process; substance; response to oxidative stress; single-organism developmental process;
tissue development aromatic compound biosynthetic process; catabolic process; cellular response to hypoxia; defense response; flower development; ion transport; organ developm

41 sccсCLзо0зв02.

peroxidase(UNIPROT) biosynthetic process; tissue development

biological regulation; cellular metabolic process; cellular response to hypoxia; hyperosmotic salinity response; ion transport; organic substance biosynthetic ozone; response to water deprivation ;response to wounding
oz

anther dehiscence; cellular amino acid metabolic process ; cellular aromatic ozone; response to water deprivation; ;response to wounding

cellular modified amino acid biosynthetic process; cold acclimation; embryo

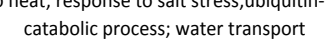
response to desiccation; response
response to oxidative stress of programmed cell death; respiratory burst; response to cold; response to

cell communication; cellular component organization or biogenesis; cellular response to hypoxia; defense response to fungus; hyperosmotic salinity

onganic rowth; response to nomatode; response to oxidative stress; single or

GO componente celular

GO função molecular

informações do kegg

\section{chloroplast envelope;chloroplast iron ion binding;linoleate 135- linoleate 9S-} stroma;chloroplast thylakoid lipoxygenase activity:linoleate lipoxygenase

membrane;plasma membrane $\quad \begin{aligned} & \text { 95-lipoxysenase activty; protein } \\ & \text { binding }\end{aligned}$

chloroplast envelope;chloroplast iron ion binding;:linoleate 135- linoleate 95stroma;chloroplast thylakoid lipoxygenase activity:linoleate lipoxygenase membrane;plasma membrane 95 -lipoxygenase activity;protein [EC:1.13.11.58];LOX

cell wall;chloroplast

envelope;chloroplast

membrane;cytosol;Golgi heme binding;--ascorbate

peroxidase activity

mal membrane;plasma

embrane;plasmodesma;vacuol membrane

apoplast; Golgi

pparatus;nucleus;plant-type cell heme binding;peroxidase E1.11.1.7; peroxidase wall;plasmodesma; vacuolar

$$
\text { membrane }
$$

$$
\text { activity }
$$

[EC:1.11.1.7]

\section{apoplast; cytosol; Golgi}

apparatus;nucleus;plant-type cell heme binding;peroxidase E1.11.1.7; peroxidase ill;plasmodesma;vacuo activity; protein bindin

\begin{tabular}{|c|c|c|}
\hline $\begin{array}{c}\text { pparatus;membrane;nucleus;plan } \\
\text { t-type cell } \\
\text { wall:plasmodesma:vacuole }\end{array}$ & $\begin{array}{l}\text { heme binding;peroxidase } \\
\text { activity;protein binding }\end{array}$ & $\begin{array}{l}\text { E1.11.1.7; peroxidase } \\
\text { [EC:1.11.1.7] }\end{array}$ \\
\hline
\end{tabular}
[EC:1.11.1.7]

apoplast; cytosol;Golgi

apoplast; cytosol;Golgi
apparatus;;membrane;plant-type heme binding;peroxidase $\quad$ E1.11.1.7; ; peroxidas cell wall;plasmodesma;vacuole

[EC:1.11.1.7]

\section{apoplast; cytosol;Golgi}

response to desectuction process; primary metabolic process; response to apparatus;membrane;nucleus; vacuole

stress;root development; tissue development
s. 
Continuação Anexo 5.

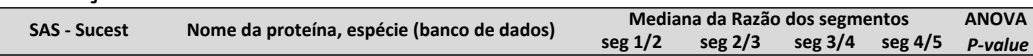

GO processo biológico

GO componente celul

GO função molecular

informações do kegg

ton transport; cell communication; cellular response to hypoxia; defense respons
to fungus; defense response to nematode; lignin metabolic process; nitrogen compound transport; organonitrogen compound metabolic process; oxidation-

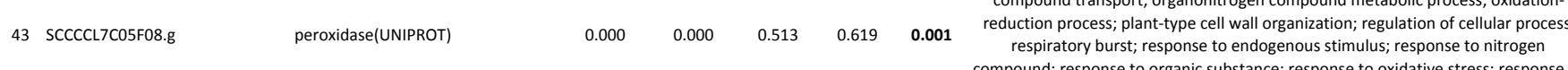
compound, response to orgasic substace

oxygen-containing compound; transition metal ion transport; trichoblast
differentiation

apoplast;cytosol;Golgi $\quad$ heme binding;peroxidase $\quad$ E1.11.1.7; peroxidas
apparatus;plant-type cell wall;vacuolar membrane

brassinosteroid biosynthetic process; cell wall polysaccharide catabolic process; cellular response to hypoxia; cellular response to iron ion starvation; defense
response to fungus; defense response to nematode; developmental growth fllower response to fungus; defense response to nematode; developmental growth; flower

development; ;yperosmotic salinity response; iron ion transport; lignin biosynthetic

44 SCCCLB1004B09.8

peroxidase(UNIPROT)

$0.534 \quad 0.881 \quad 0.901$

process ; mucilage extrusion from seed coat; nitrate transport; oxidation-reduction burst; response to cold; response to desiccation; response to nitrate; response to oxidative stress; root hair cell differentiation

cell wall polysaccharide catabolic process; cellular response to hypoxia; defense response to bacterium; defense response to fungus; defense response to nematode;

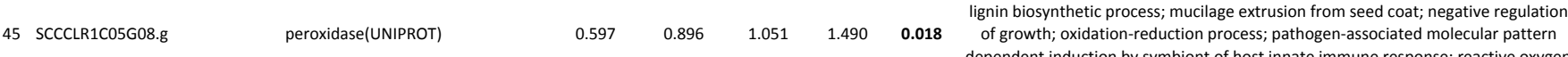
species metabolic process; response to light stimulus; response to oxidative stress; response to salt stress; unidimensional cell growth cell wall polysaccharide catabolic process; cellular response to hypoxia; defense
response to bacterium; defense response to fungus; defense response to nematode

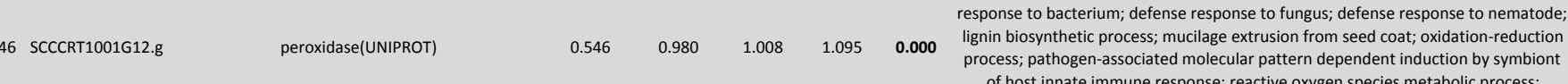
of host innate immune response; reactive oxygen species metabolic process; response to light stimulus; response to oxidative stress; unidimensional cell growth cell wall polysaccharide catabolic process; cellular response to hypoxia; defense response to bacterium; defense response to fungus; defense response to nematode ,flower development; ;ignin biosynthetic process; mucilage extrusion from seed coat, negative regulation of growth; oxidation-reduction process; pathogen-
associated molecular pattern dependent induction by symbiont of host innate associated molecular pattern dependent induction by symbiont of host innate
immune response; reactive oxygen species metabolic process; response to light stimulus; response to oxidative stress; response to salt stress; response to zinc ion unidimensional cell growth

cellular response to hypoxia; defense response to fungus; defense response to nematode; hyperosmotic salinity response; ion transport; lignin biosynthetic cess; oxidation-reduction process; plant-type cell wall organization; regulation of
cellular process; respiratory burst; response to cold; response to desiccation: response to oxidative stress; trichoblast differentiation
restions

brassinosteroid biosynthetic process; cellular response to iron ion starvation; defense response to fungus; developmental growth; hyperosmotic salinity response; iron ion transport; lignin biosynthetic process; nitrate transport; oxidation-reduction process; plant-type cell wall organization; post-embryonic development; postembrys plic oran development, regution of celliar process, espiratory burst; esponse to oxidative cell wall polysaccharide catabolic process; cellular response to hypoxia; defense response to fungus; defense response to nematode; flower development;

$\begin{array}{llllllll}50 \text { SCEQRT1026F09.g } & \text { peroxidase(UNIPROT) } & 0.227 & 0.678 & 0.896 & 0.967 & 0.000 & \begin{array}{c}\text { hyperosmotic salinity response; in transport lignin biosynthetic process; mucilage } \\ \text { extrusion from seed coat; oxidation-reduction process; plant-type cell wall } \\ \text { organization; regulation of cellular process; respiratory burst; response to cold; }\end{array}\end{array}$

$\begin{array}{llllllll}50 \text { SCEQRT1026F09.g } & \text { peroxidase(UNIPROT) } & 0.227 & 0.678 & 0.896 & 0.967 & 0.000 & \begin{array}{c}\text { hyperosmotic salinity response; in transport lignin biosynthetic process; mucilage } \\ \text { extrusion from seed coat; oxidation-reduction process; plant-type cell wall } \\ \text { organization; regulation of cellular process; respiratory burst; response to cold; }\end{array}\end{array}$ response to desiccation; response to oxidative stress cell wall organization or biogenesis; cellular response to stress; organ development; organic substance biosynthetic process; oxidation-reduction process; phenylpropanoid metabolic process; primary metabolic process; response to ab
stimulus;response to inorganic substance; response to oxidative stress

51 SCEQRT1028D12.g

peroxidase(UNIPROT)

$\begin{array}{lllll}1.134 & 1.074 & 1.025 & 1.509 & 0.20\end{array}$

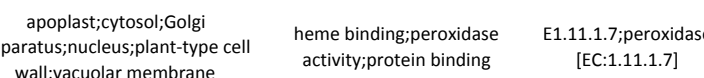
reticulum;Golgi
pparatus;membrane;nucleus,plats

heme binding;peroxidase
activity:transferase activity, E1.11.1.7; peroxidase transferring glycosyl groups

[EC.111117] atype cell wall;plasmodesma

\begin{tabular}{|c|c|c|}
\hline $\begin{array}{l}\text { apoplast; cytosol;Golgi } \\
\text { paratus;nucleus;plant-type cell } \\
\text { wall;vacuolar membrane }\end{array}$ & $\begin{array}{l}\text { heme binding;peroxidase } \\
\text { activity;protein binding }\end{array}$ & $\begin{array}{l}\text { E1.11.1.7.peroxidase } \\
\text { [EC:1.11.1.7] }\end{array}$ \\
\hline
\end{tabular}

apoplast;cytosol;Golgi
apparatus;nucleus;plant-type cell $\begin{gathered}\text { heme binding;peroxidase } \\ \text { activity:protein binding }\end{gathered} \quad \begin{aligned} & \text { E1.11.1.7; peroxidase } \\ & \text { [EC:1.11.1.7] }\end{aligned}$ wall;vacuolar membran [EC:1.11.1.7]

\section{apoplast;Golgi}

apoplast;Golgi
apparatus;nucleus;plant-type cell
wall:plasmodesma;vacuolar $\begin{gathered}\text { heme binding;peroxidase } \\ \text { activity }\end{gathered}$
membrane

[EC:1.11.1.7]

apoplast;endoplasmic $\begin{array}{ccc}\text { reticulum;Golgi } & \text { heme binding;peroxidase } & \\ \text { activity;transferase activity, } & \text { E1.11.1.7; peroxidase } \\ \text { apcC:1.11.1.7] }\end{array}$ activity: transferase activity,

\section{apoplast; cytosol;Golg}

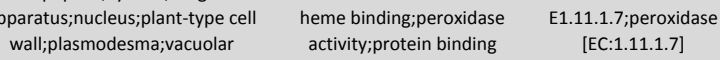
membrane

cell wall:extracellular heme binding;peroxidase E1.11.1.7; peroxidase activity [EC:1.11.1.7]

52 SCEQRT1028HO9.g peroxidase(UNIPROT)

$\begin{array}{llllll}1.279 & 1.187 & 1.241 & 1.442 & 0.086\end{array}$ oxidation-reduction process; response to oxidative stres 
Continuação Anexo 5.

SAS- Sucest

Nome da proténa, espécie (banco de dados)

Mediana da Razão dos segmentos
ANOVA

GO processo biológico

GO componente celular

GO função molecular

informações do kegg

brassinosteroid biosynthetic process; cellular response to hypoxia; cellular response

to iron ion starvation; developmental growth; hyperosmotic salinity response; iron

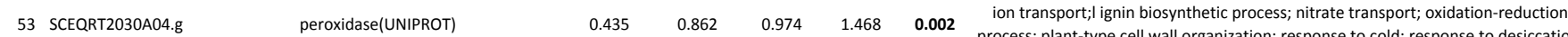
process; plant-type cell wall organization; response to cold; response to desiccation;
response to nitrate; response to other organism; response to oxidative stress; root response to nitrate; response to other organism; response to oxidative stress; root
hair cell differentiation; xylan metabolic process

heme binding;peroxidase

$\begin{array}{ll}\text { t-type cell wall;plasmodesma } & \begin{array}{l}\text { binding;transferase activity, } \\ \text { transferring glycosyl groups }\end{array}\end{array}$

E1.11.1.7; peroxidase

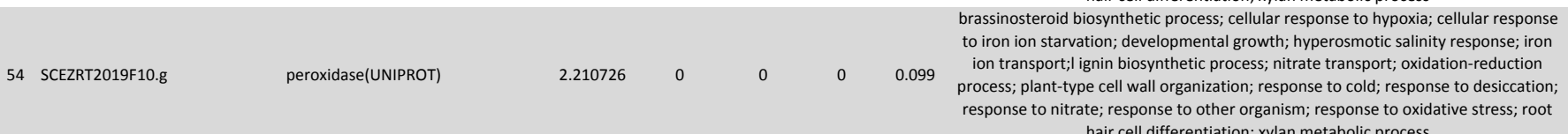

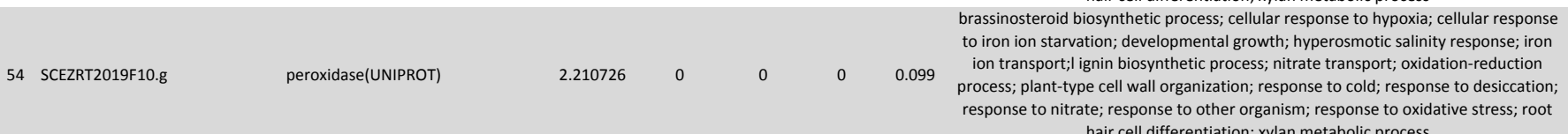
heme binding;peroxidas [EC:1.11.1.7] heme binding;peroxidase
activity;protein $\quad$ E1.11.1.7. peroxidase Binding, rinsterase activity, $\quad[\mathrm{EC}: 1.11 .1 .7]$ hair cell differentiation; xylan metabolic process

transferring glycosyl groups

:1.11.1.7]

$\begin{array}{llllllll}55 & \text { SCIFLR1035D05.g } & \text { peroxidase(UNIPROT) } & 0.1745353 & 0.537461 & 0.89681 & 1.1348 & 0.000\end{array}$
oxidation-reduction process; response to oxidative stress cell communication; cellular response to stimulus; defense response to fungus; response; inorganic anion transport; lignin metabolic process; nitrogen compound

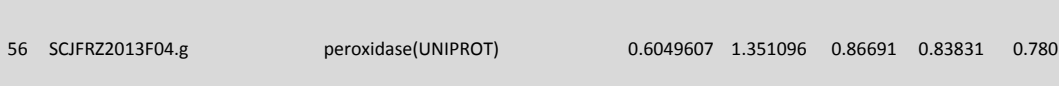
transport; oxidation anion transport; ilgnin metabolic process; nitrogen compound metabolic process; regulation of cellular process; respiratory burst; response to cold stress; root hair cell differentiation; transition metal ion transport

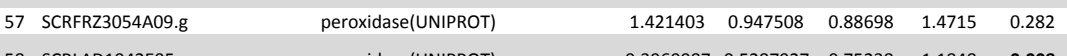

$\begin{array}{llllllll}58 & \text { SCRLAD1042E05.g } & \text { peroxidase(UNIPROT) } & 0.3969987 & 0.5287927 & 0.75238 & 1.1848 & 0.008\end{array}$

Cell wall organization; cellular macromolecule metabolic process; immune response defense response to bacterium; defense response to fungus; defense response to nematode; hyperosmotic salinity response; ion transport; lignin biosynthetic

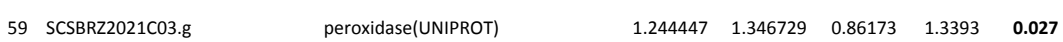
process; oxidation-reduction process; pathogen-associated molecular pattern metabolic process; reactive oxygen species metabolic process; response to cold response to desiccation; response to light stimulus; response to oxidative stress; root development; tissue development; unidimensional cell growth

cell wall polysaccharide catabolic process; cellular response to hypoxia; defense

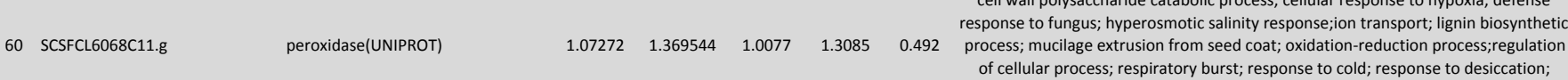
of cellular process; respiratory burst; response to cold; response to desication;
response to oxidative stress aromatic compound biosynthetic process; catabolic process;cell wall organization or biogenesis; cellular response to stress; defense response; flower developmention transport; lignin metabolic process; organ development; organic cyclic compoun
biosynthetic process; oxidation-reduction process; primary metabolic process; biosynthetic process; oxidation-reduction process;primary metabolic process;
regulation of growth; response to chemical stimulus; response to nematode; regulation of growth;response to chemical stimulus; response to nematods;
response to oxidative stress; single-organism biosynthetic process; tissue

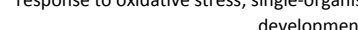

development cell wall polysaccharide catabolic process,
esponse to fungus; hyperosmotic salinity response;ion transport; lignin biosynthetic

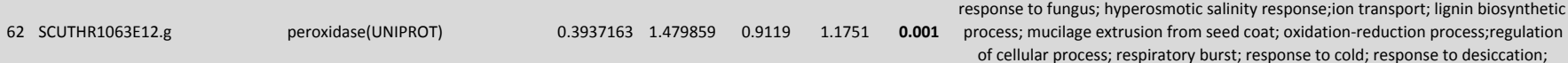
of cellular process; respiratory burst; response to cold; response to desiccation;
response to oxidative stress response to oxidative stress

$$
\begin{aligned}
& \text { development; cell wall organization or biogenesis; defense resp } \\
& \text { bacterium; defense response to fungus; defense response to } \\
& \text { ode:hyperosmotic salinity response; ion transport:negative regula }
\end{aligned}
$$
growth; organic substance biosynthetic process; oxidation-reduction process;

pathogen-associated molecular pattern dependent induction by symbiont of hos innate immune response; primary metabolic process; reactive oxygen species metabolic process; regulation of meristem growth;response to cold;response to desiccation; response to light stimulus; response to oxidative stress; unidimensio
cell growth cellular metabolic process; organ development; organic substance metabolic

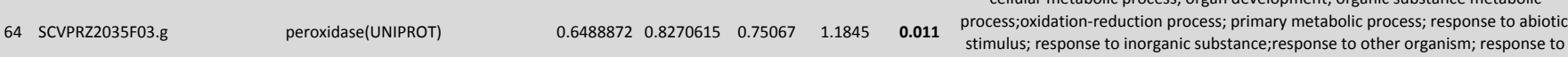
oxidative stress;response to oxygen-containing compound; tissue development

apoplast;Golgi

(us;nucleus;plant-type cell $\quad$ heme binding;peroxidase $\quad$ E1.11.1.7peroxidas wall;plasma activity
[EC:1.111.1.7]

\section{anchored to plasma \\ chitin binding;peptidoglycan} apoplast; cytosol;Golgi

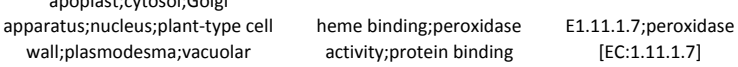
mosma, vacuor

\begin{tabular}{|c|c|}
\hline $\begin{array}{l}\text { oplast;membrane;nucleus;plant- } \\
\text { type cell } \\
\text { wall:plasmodesma:vacuole }\end{array}$ & $\begin{array}{l}\text { heme binding;peroxidase } \\
\text { activity }\end{array}$ \\
\hline
\end{tabular}

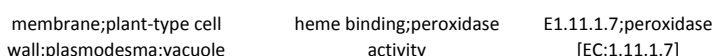
$\begin{array}{lcr}\text { membrane;plant-type cell } & \text { heme binding;peroxidase } & \text { E1.11.1.7; peroxid } \\ \text { wall;plasmodesma;vacuole } & \text { activity } & \text { [EC:1.11.1.7] }\end{array}$ apoplast:cytosol:Golgi
paratus;nucleus;plant-type cell heme binding;peroxidase E1.11.1.7; peroxidase wall; vacuolar membran [EC:1.11.1.7]

poplast;Golgi apparatus;plant$\begin{array}{ccc}\text { type cell } & \text { heme binding;peroxidase } & \text { E1.11.1.7; peroxidase } \\ \text { activity;protein binding } & \text { [EC:1.11.1.7] }\end{array}$ cell wall;cytoplasmic
part; extracellular region;intracellular memb
bounded organelle 
Continuação Anexo 5.

\begin{tabular}{|c|c|c|c|c|c|c|c|c|c|c|}
\hline SAS - Sucest & Nome da proteína, espécie (banco de dados) & $\begin{array}{l}\text { Median } \\
\text { seg } 1 / 2\end{array}$ & $\begin{array}{l}\text { na da Razão } \\
\text { seg 2/3 }\end{array}$ & $\begin{array}{l}\frac{1}{\text { dos segme }} \\
\text { seg } 3 / 4\end{array}$ & $\begin{array}{l}\text { entos } \\
\text { seg } 4 / 5\end{array}$ & $\begin{array}{l}\text { ANOVA } \\
P \text {-value } \\
\end{array}$ & GO processo biológico & GO componente celular & GO função molecular & informações do kegg \\
\hline 65 SCSGLR1045G11.g & $\begin{array}{l}\text { Probable calcium-binding protein CML7 } \\
\text { (Calmodulin-like protein 7)(UNIPROT) }\end{array}$ & 0.6347594 & 1.328868 & 1.0029 & 0.62837 & 0.637 & $\begin{array}{l}\text { calcium-mediated signaling; cell growth; developmental growth involved in } \\
\text { morphogenesis; intracellular transport; membrane organization; organelle } \\
\text { localizatio;nrespons se to cold; response to endogenous stimulus; response to } \\
\text { mechanical stimulus; response to organic substance; response to water deprivation; } \\
\text { root epidermal cell differentiation; starch metabolic process }\end{array}$ & $\begin{array}{l}\text { cytosol;nucleus;plasma } \\
\text { membrane;vacuolar membrane }\end{array}$ & $\begin{array}{l}\text { calcium ion binding;protein } \\
\text { binding;signal transducer } \\
\text { activity }\end{array}$ & $\begin{array}{l}\text { calcium-binding } \\
\text { protein CML;CML }\end{array}$ \\
\hline 66 SCCCRT2002H05.g & $\begin{array}{l}\text { Probable cytochrome c biosynthesis } \\
\text { protein(UNIPROT) }\end{array}$ & 0.6026275 & 0.966931 & 0.80907 & 1.0376 & 0.908 & & & & \\
\hline 67 SCVPRT2080B07.g & Protease inhibitor(UNIPROT) & 0.269266 & 0.7713074 & 0.57397 & 1.0858 & 0.000 & $\begin{array}{l}\text { cellular component organization; cellular metabolic process; defense response; } \\
\text { immune system process; organic substance metabolic process; response to chemical } \\
\text { stimulus; response to other organism }\end{array}$ & cell part & & \\
\hline 68 SCJLRT2051607.g & Protease inhibitors(UNIPROT) & 0.2314065 & 0.2357934 & 0.93793 & 0.68384 & 0.000 & $\begin{array}{l}\text { cellular component organization; defense response to bacterium, incompatible } \\
\text { interaction; defensens response to funguss, incompatible interaction; ; ragan } \\
\text { development; regulation of anthocyanin biosynthetic process; regulation of cellular } \\
\text { metabolic process; regulation of defense response; regulation of macromolecule } \\
\text { metabolic process; response to cadmium ion; response to organic substance; } \\
\text { response to oxygen-containing compound; response to salt stress; response to UV-B; } \\
\text { response to virus; signal transduction; systemic acquired resistance }\end{array}$ & $\begin{array}{c}\text { apoplast; cell } \\
\text { wall;membrane;vacuole }\end{array}$ & & \\
\hline 69 SCVPRT2073B04.g & Protease inhibitors(UNIPROT) & 0.4721213 & 0.3156566 & 0.79304 & 0.58405 & 0.008 & 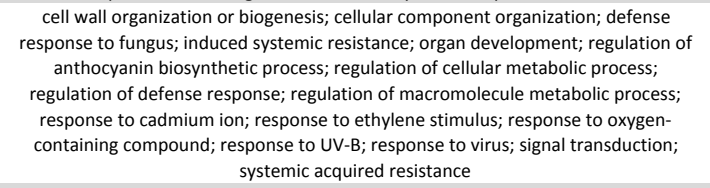 & $\begin{array}{l}\text { apoplast;cell } \\
\text { wall;membrane;lasmodesma;vac } \\
\text { uole }\end{array}$ & & \\
\hline 70 SCEZLB1007G10.g & $\begin{array}{l}\text { Serine carboxypeptidase } 2 \text { OS=Triticum aestivum } \\
\text { GN=CBP2 PE=1 SV=2 (UNIPROT) }\end{array}$ & 1.445818 & 0.8525149 & 1.2838 & 1.1874 & 0.838 & $\begin{array}{l}\text { brassinosteroid mediated signaling pathway; microtubule nucleation; proteolysis; } \\
\text { second-messenger-mediated signaling }\end{array}$ & $\begin{array}{l}\text { extracellular space;plant-type cell } \\
\text { wall;;vacuole }\end{array}$ & $\begin{array}{l}\text { serine-type carboxypeptidase } \\
\text { activity }\end{array}$ & $\begin{array}{l}\text { SCPL-II;serine } \\
\text { carboxypeptidase-like } \\
\text { clade II [EC:3.4.16.-] }\end{array}$ \\
\hline 71 SCEZRZ3016H03.g & $\begin{array}{l}\text { Serine carboxypeptidase Il-3 OS=Hordeum vulgare } \\
\qquad N=C X P ; 2-3 P E=2 S V=1 \text { (UNIPROT) }\end{array}$ & 0 & 0 & 0 & 0.80211 & 0.648 & $\begin{array}{l}\text { brassinosteroid mediated signaling pathway; cellular component organization; } \\
\text { proteolysis }\end{array}$ & $\begin{array}{l}\text { extracellular space;plant-type cell } \\
\text { wall;;vacuole }\end{array}$ & $\begin{array}{l}\text { serine-type carboxypeptidase } \\
\text { activity }\end{array}$ & $\begin{array}{l}\text { SCPL-II;serine } \\
\text { carboxypeptidase-like } \\
\text { clade II [EC:3.4.16.-] }\end{array}$ \\
\hline 72 SCBFRZ2017A10.g & $\begin{array}{l}\text { Serine carboxypeptidase-like OS=Oryza sativa } \\
\text { subsp. japonica GN=CBP31 PE=2 SV=2 (UNIPROT) }\end{array}$ & 1.904327 & 0.6492242 & 0.91579 & 1.1006 & 0.036 & proteolysis & cytosol;extracellular region;vacuole & $\begin{array}{l}\text { serine-type carboxypeptidase } \\
\text { activity }\end{array}$ & $\begin{array}{l}\text { SCPL-IV;serine } \\
\text { carboxypeptidase-like } \\
\text { clade IV [EC:3.4.16.-] }\end{array}$ \\
\hline 73 SCCCLR1C01H05.g & $\begin{array}{l}\text { Similar to Hordeum vulgare carboxypeptidase D } \\
\text { (Putative carboxypeptidase D)(UNIPROT) }\end{array}$ & 1.105131 & 1.208912 & 1.3226 & 1.1792 & 0.307 & $\begin{array}{l}\text { brassinosteroid mediated signaling pathway; microtubule nucleation; proteolysis; } \\
\text { second-messenger-mediated signaling }\end{array}$ & $\begin{array}{l}\text { extracellular space;plant-type cell } \\
\text { wall;;vacuole }\end{array}$ & $\begin{array}{l}\text { serine-type carboxypeptidase } \\
\text { activity }\end{array}$ & $\begin{array}{l}\text { SCPL-II;serine } \\
\text { carboxypeptidase-like } \\
\text { clade II [EC:3.4.16.-] }\end{array}$ \\
\hline 74 SCJFRT2057F01.g & $\begin{array}{l}\text { Subtilisin-like protease OS=Arabidopsis thaliana } \\
\text { GN=ARA12 PE=1 SV=1 (UNIPROT) }\end{array}$ & 1.010601 & 0.8883361 & 0.93762 & 1.2203 & 0.134 & $\begin{array}{l}\text { alpha-amino acid metabolic process; carbohydrate derivative biosynthetic } \\
\text { process;cellular amino acid biosynthetic process;cellular macromolecule metabolic } \\
\text { process; lateral root morphogenesis; mucilage extrusion from seed coat; plant-type } \\
\text { cell wall modification; proteolysis; regulation of cell proliferation; response to auxin } \\
\text { stimulus }\end{array}$ & $\begin{array}{l}\text { apoplast; cytososi;external side of } \\
\text { plasma membrane;extracellular } \\
\text { matrix; Golgi apparatus;plant-type } \\
\text { cell wall;plasmodesmajavacuolar } \\
\text { membrane }\end{array}$ & $\begin{array}{l}\text { serine-type endopeptidase } \\
\text { activity }\end{array}$ & \\
\hline 75 SCRFHR1007E04.g & $\begin{array}{l}\text { Subtililisin-like protease OS=Arabidopsis thaliana } \\
\text { GN=ARA12 PE=1SV=1 (UNIPROT) }\end{array}$ & 0.9053051 & 0.9413537 & 1.032 & 1.0294 & 0.321 & $\begin{array}{l}\text { anther development; ion transport; lateral root morphogenesis; mucilage extrusion } \\
\text { from seed coat; plant-type cell wall biogenesis and modification; polysaccharide } \\
\text { metabolic process; proteolysis; regulation of celll proliferation; regulation of } \\
\text { meristem growth; response to auxin stimulus; RNA splicing, via endonucleolytic } \\
\text { cleavage and ligation }\end{array}$ & $\begin{array}{c}\text { apoplast; cytososi;external side of } \\
\text { plasma membrane;extracelllular } \\
\text { matrix;Golgi } \\
\text { apparatus;inucless;lant-type cell } \\
\text { wall;pplasmodesma;vacuolar } \\
\text { membrane }\end{array}$ & $\begin{array}{l}\text { serine-type endopeptidase } \\
\text { activity }\end{array}$ & \\
\hline 76 SCCCLR1024E11.g & $\begin{array}{l}\text { Superoxide dismutase [Cu-Zn] } 2 \text { OS=Zea mays } \\
G N=S O D C C .1 P E=2 S V=2 \text { (UNIPROT) }\end{array}$ & 1.124391 & 0.8681309 & 0.90466 & 0.7816 & 0.436 & $\begin{array}{l}\text { cellular response to copper ion; cellular response to ozone; cellular response to salt } \\
\text { stress; cellular response to sucrose stimulus; cellular response to UV-B; defense } \\
\text { response to bacterium; gene silencing by mirNA; oxidation-reduction process; } \\
\text { removal of superoxide radicals; response to cadmium ion;response to iron ion; toxin } \\
\text { catabolic process }\end{array}$ & $\begin{array}{l}\text { apoplast;chloroplast } \\
\text { stroma; cytosol;nucleus;peroxisom } \\
\text { e,thylakoid;;vacuole }\end{array}$ & $\begin{array}{l}\text { copper ion binding; protein } \\
\text { binding;superoxide dismutase } \\
\text { activity;zinc ion binding }\end{array}$ & $\begin{array}{c}\text { SOD1;superoxide } \\
\text { dismutase, Cu-Zn } \\
\text { family [EC:1.15.1.1] }\end{array}$ \\
\hline 77 SCCCLR1048A06.g & Superoxide dismutase(UNIPROT) & 1.047548 & 0.8683571 & 1.111 & 0.89888 & 0.043 & $\begin{array}{l}\text { aerobic respiration; defense response to bacterium; embryo development ending in } \\
\text { seed dormancy; floral organ abscission; gibberellic acid mediated signaling pathway; } \\
\text { gibberellin biosynnthetic process; Golgi organization; ;yperosmotit response; } \\
\text { photoresppiration; removal of superoxide radicals ; response to cadmium ion; } \\
\text { response to salt stress; response to temperature stimulus; response to zinc ion; } \\
\text { ubiquitin-dependent protein catabolic process; water transport }\end{array}$ & $\begin{array}{l}\text { chloroplast stroma; } \\
\text { mitochondrion;plastid nucleoid }\end{array}$ & $\begin{array}{l}\text { copper ion binding;superoxide } \\
\text { dismutase activity }\end{array}$ & $\begin{array}{l}\text { SOD2; superoxide } \\
\text { dismutase, Fe-Mn } \\
\text { family [EC:1.15.1.1] }\end{array}$ \\
\hline 78 SCCCLR2C03D05.g & Superoxide dismutase(UNIPROT) & 0.9465216 & 0.8791981 & 0.91927 & 0.74657 & 0.508 & $\begin{array}{l}\text { cellular response to copper ion; cellular response to ozone; cellular response to salt } \\
\text { stress; cellular response to sucrose stimulus; cellular response to UV-B; defense } \\
\text { response to bacterium; gene silencing by miRNA; oxidation-reduction } \\
\text { process;removal of superoxide radicals; response to cadmium ion; response to iron } \\
\text { ion; toxin catabolic process }\end{array}$ & $\begin{array}{l}\text { apoplast; chloroplast stroma; } \\
\text { cytosol;nucleus; peroxisome; } \\
\text { thylakood; vacuole }\end{array}$ & $\begin{array}{l}\text { copper ion binding;:protein } \\
\text { binding;suuperoxide dismutase } \\
\text { activity;izic ion binding }\end{array}$ & $\begin{array}{c}\text { SOD1; superoxide } \\
\text { dismutase, Uu-Zn } \\
\text { family [EC:1.15.1.1] }\end{array}$ \\
\hline
\end{tabular}




\section{Continuação Anexo 5.}

\section{SAS- Sucest}

Nome da proteína, espécie (banco de dados) 79 SCAGLR1021H06.g Thiol protease SEN102 OS=Hemerocallis 5 GN=SEN102 PEE2 SV=1 (UNIPROT)

$\begin{array}{llll}0.1775348 & 0.4066859 & 0.75073 & 0.97806\end{array}$ defense response to fungus, incompatible interaction; developmental programmed cell death; Golgi organization; hydrogen peroxide catabolic process; hyperosmotic
salinity response; leaf senescence; plant-type cell wall organization; proteolysiss regulation of meristem growth; response to cadmium ion; response to ethylen

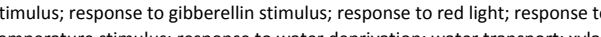

\section{ATP hydrolysis coupled proton transport; ATP metabolic process; calcium ion
transport; celll growth; cell morphogenesis; cytoskeleton organization; Golgi $\begin{array}{ll}80 \text { SCAGLR1043D04.g } & \begin{array}{l}\text { V-type proton ATPase catalytic subunit } \\ \text { OS=Daucus carota PE=2 SV=1 (UNIPROT) }\end{array}\end{array}$ $\begin{array}{lllll}1.581203 & 0.9007386 & 1.1196 & 1.0767 & 0.485\end{array}$ organization; Golgi vesicle transport; hyperossmotic response; pentose-phosphat shunt; proteasomal protein catabolic process; regulation of biological quality; response to temperature stimulus; vacuole organization; water transport}

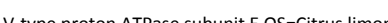
GN=VATE PE=2 SV=1 (UNIPROT)

$\begin{array}{lllll}1.977027 & 0.784683 & 1.2554 & 0.82382 & 0.003\end{array}$ development ending in seed dormancy;igycolysis; Golgi organization; hyperosmotic
response; plant

apoplast; cell wall Calcium ion binding.cysteine- CEP,KDEL-tailed type peptidase activity:protein cysteine nescence-associated vacuole

apoplast:cell wall:chloroplast envelope;chloroplast
thylakoid;cytosol;Golgi thylakoid;cytosol;:Golgi
paratus;itochondrial prototransporting ATP synthose ATP binding;protease binding;proton-transporting

cell wall polysaccharide metabolic process; cellular biosynthetic process; cellular component organization; efense response to fungus, incompatible interaction
;developmental programmed cell death; hyperosmotic salinity response - leaf ethylene stimulus; response to gibberellin stimulus; response to inorganic substan

$\begin{array}{llllllll}82 & \text { SCSFRT2069E03.g } & \text { Water stress(UNIPROT) } & 0.266184 & 0.8668516 & 1.0525 & 1.1041 & 0.064\end{array}$ carboxylic acid biosynthetic process; defense response to fungus; developmental programmed cell death; glucuronoxylan metabolic process; glycolysis; Golgi

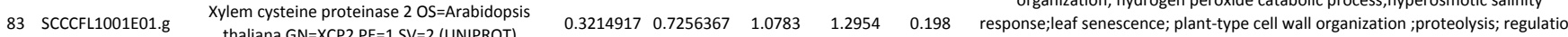
thaliana GN=XCP2 PE=1 SV=2 (UNIPROT) response to gibberellin stimulus; response to temperature stimulus; response to
ATP hydrolysis coupled proton transport; ATP synthesis coupled proton plant-type cell wall biogenesis; response to cadmium ion;respons
response to salt stress; vacuole organization; water transport ansporting ATP synthase vacuole;plasma
valter

$\begin{array}{ll}\text { ATP synthase activity, } & \text { ATPeV1A;V-type H+- } \\ \text { transporting ATPase }\end{array}$

embrane;plasmodesma;protontransporting V-type ATPase, V1 membrane

cytosolic ribosome;Golgi transporting ATP synthase (c) vacuole membrane; protontransporting two-sector ATPase complex, catalytic dom senescence; organic substance biosynthetic process; proteolysis; response to

apoplast; cell
wall;; chloroplast;cytosol; endoplasm calcium ion binding;cysteinereticulum;nucleus;plasmodesma; nescence-associated vacuole apoplast;cell
wall; chloroplast; ;ytosol; endoplasm calcium ion binding;cysteine- $\quad$ XCP;:xylem cysteine reticulum;nucleus;plasmodesma;se $\begin{gathered}\text { type peptidase activity;protein proteinase } \\ \text { binding }\end{gathered}$ nescence-associated vacuole transition

binding

hydrogen-exporting ATPase activity, phosphorylative transporting ATPase activity, A Pubunit E
susperting ATPas
. sponse to gibberellin stimulus; response to temperature stimulus; response
water deprivation; water transport xylan biosynthetic process transporting ATPase activity, $\begin{gathered}\text { transporting ATPase } \\ \text { subunit A ECC:3.6.3.14 }\end{gathered}$ 


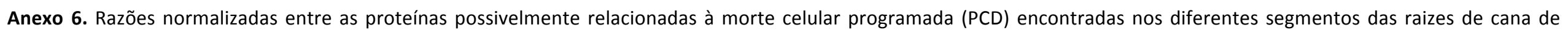

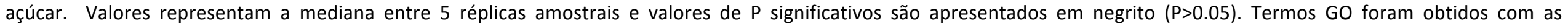

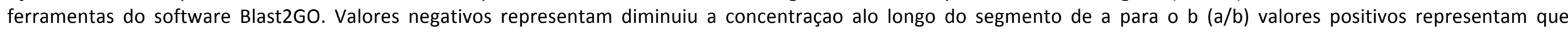
aumentou a concetração ao longo dos segmentos de a para $b$.

\begin{tabular}{|c|c|c|c|c|c|c|c|c|c|c|c|}
\hline & SAS - Sucest & Nome da proteína, espécie (banco de dados) & $\operatorname{seg} 1 / 2$ & $\begin{array}{l}\text { Mediana d } \\
\text { seg 2/3 }\end{array}$ & $\begin{array}{l}\text { as razōes } \\
\text { seg } 3 / 4\end{array}$ & $\operatorname{seg} 4 / 5$ & $\begin{array}{l}\text { ANOVA } \\
\text { P-value }\end{array}$ & GO processo biológico & GO componente celular & GO função molecular & informações do kegg \\
\hline 1 & SCACLR1057G08.g & $\begin{array}{l}\text { Activator of } 90 \mathrm{kDa} \text { heat shock protein ATPase } \\
\text { homolog 1;AHA1(UNIPROT) }\end{array}$ & -0.448 & 0.223 & -0.707 & 0.387 & 0.012 & $\begin{array}{l}\text { protein folding; response to endoplasmic reticulum stress; response to } \\
\text { heat; response to high light intensity; response to hydrogen peroxide }\end{array}$ & cytosol; nucleus & $\begin{array}{c}\text { ATPase activator } \\
\text { activity; chaperone binding }\end{array}$ & \\
\hline 2 & SCRLRZ3042B09.g & $\begin{array}{l}\text { Aspartic proteinase nepenthesin-1 OS=Nepenthes } \\
\text { gracilis } G N=n e p 1 P E=1 S V=1 \text { (UNIPROT) }\end{array}$ & -0.977 & 0.031 & 0.080 & -0.307 & 0.006 & $\begin{array}{l}\text { cell wall modification; cellular metabolic process;defense response ;plant-type cell } \\
\text { wall organization;proteolysis; regulation of cellular process; response to abscisic acid } \\
\text { stimulus; response to karrikin; response to other organism; response to water } \\
\text { deprivation }\end{array}$ & $\begin{array}{l}\text { endoplasmic reticulum; } \\
\text { extracellular region; membrane; } \\
\text { plant-type cell wall; plasmodesma }\end{array}$ & $\begin{array}{l}\text { aspartic-type endopeptidase } \\
\text { activity }\end{array}$ & \\
\hline 3 & SCCCLB1004B02.g & $\begin{array}{l}\text { ATP synthase subunit alpha, } \\
\text { mitochondrial(UNIPROT) }\end{array}$ & 0.617 & 0.113 & -0.351 & -0.386 & 0.002 & $\begin{array}{l}\text { ATP hydrolysis coupled proton transport; cell growth; cellulose metabolic process; } \\
\text { dATP biosynthetic process from ADP; defense response to bacterium; DNA- } \\
\text { dependent transcription, elongation; plant-type cell wall biogenesis; response to } \\
\text { cold; response to oxidative stress }\end{array}$ & $\begin{array}{l}\text { cell wall; chloroplast ATP synthase } \\
\text { complex; Golgi apparatus; } \\
\text { mitochondrial proton-transporting } \\
\text { ATP synthase complex; nucleolus; } \\
\text { plasma membrane; ATPase } \\
\text { complex, catalytic domain vacuolar } \\
\text { membrane }\end{array}$ & $\begin{array}{l}\text { ATP binding; cobalt ion binding; } \\
\text { copper ion binding; proton- } \\
\text { transporting ATP synthase } \\
\text { activity, rotational mechanism }\end{array}$ & $\begin{array}{l}\text { ATPeF1A;F-type H+- } \\
\text { transporting ATPase } \\
\text { subunit alpha }\end{array}$ \\
\hline 4 & SCCCRZ2001D06.g & $\begin{array}{l}\text { ATP synthase subunit beta, } \\
\text { mitochondrial;(UNIPROT) }\end{array}$ & -0.160 & -0.032 & -0.018 & -0.108 & 0.161 & $\begin{array}{l}\text { ATP catabolic process; ATP hydrolysis coupled proton transport; ATP synthesis } \\
\text { coupled proton transport; carbohydrate metabolic process; defense response to } \\
\text { fungus, incompatible interaction; DNA-dependent transcription, elongation; } \\
\text { generation of precursor metabolites and energy; organelle organization; response to } \\
\text { cold; response to oxidative stress }\end{array}$ & $\begin{array}{l}\text { cell wall; chloroplast ATP synthase } \\
\text { complex; cytosol;Golgi apparatus; } \\
\text { mitochondrial respiratory chain } \\
\text { complex I; nucleolus; plasma } \\
\text { membrane; vacuolar membrane }\end{array}$ & $\begin{array}{l}\text { ATP binding; cobalt ion } \\
\text { binding;copper ion binding; } \\
\text { poly(U) RNA binding;iproton- } \\
\text { transporting ATP synthase } \\
\text { activity, rotational mechanism; } \\
\text { zinc ion binding }\end{array}$ & $\begin{array}{l}\text { ATPeF1B;F-type H+- } \\
\text { transporting ATPase } \\
\text { subunit beta } \\
\text { [EC:3.6.3.14] }\end{array}$ \\
\hline 5 & SCCCCL4015F12.g & $\begin{array}{l}\text { Basic } 75 \text { globulin;SBg75;Bg;Basic 7S globulin high } \\
\text { kDa subunit;:Basic 7S globulin low kDa } \\
\text { subunit;(UNIPROT) }\end{array}$ & -0.433 & -0.302 & -0.159 & -0.033 & 0.765 & proteolysis & cell periphery & $\begin{array}{l}\text { aspartic-type endopeptidase } \\
\text { activity }\end{array}$ & \\
\hline 6 & SCAGLB2046F01.g & $\begin{array}{l}\text { Bowman-Birk type bran trypsin inhibitor precursor } \\
\text { (Protein RBBI3-3) (RBTI) (OSE727A)(UNIPROT) }\end{array}$ & 0.761 & 0.363 & -0.248 & -0.406 & 0.000 & & extracellular region & $\begin{array}{l}\text { serine-type endopeptidase } \\
\text { inhibitor activity }\end{array}$ & \\
\hline 7 & scCCCL2001B01.b & calmodulin-binding protein(UNIPROT) & 0.535 & 0.022 & 0.209 & -0.062 & 0.000 & $\begin{array}{l}\text { cellular component organization or biogenesis;D-xylose metabolic process;pollen } \\
\text { germination;single-organism cellular process }\end{array}$ & $\begin{array}{l}\text { endosome; extracellular space; } \\
\text { Golgi apparatus; integral to } \\
\text { membrane; ;plasma membrane; } \\
\text { trans-Golgi network }\end{array}$ & $\begin{array}{l}\text { ATPase activity;calmodulin } \\
\text { binding;guanosine- } \\
\text { diphosphatase activity;inosine- } \\
\text { diphosphatase activity;uridine- } \\
\text { diphosphatase activity }\end{array}$ & $\begin{array}{c}\text { APY1_2;apyrase } \\
\text { [EC:3.6.1.5] }\end{array}$ \\
\hline 8 & SCVPLR1049C09.g & calmodulin-binding protein(UNIPROT) & -2.217 & 0.031 & -0.575 & 0.233 & 0.000 & $\begin{array}{l}\text { cell cycle process; cell division; cell wall organization; cytoplasmic transport; defense } \\
\text { response to bacterium; Golgi vesicle transport; lateral root formation; maintenance } \\
\text { of root meristem identity; meristem growth; meristem structural organization; } \\
\text { organic substance transport; phosphorylation; phototropism; plant-type cell wall } \\
\text { organization or biogenesis; pollen development; polysaccharide biosynthetic } \\
\text { process; proteasomal ubiquitin-dependent protein catabolic process; proteasome } \\
\text { core complex assembly; protein glycosylation; regulation of cellular component } \\
\text { organization; regulatiton of gene silencin; response to cadmium ion; ;response to } \\
\text { heat; response to misfolded protein; RNA processing;root cap development; }\end{array}$ & $\begin{array}{l}\text { apoplast; cell wall; chloroplast } \\
\text { thylakoid membrane; cytosolic } \\
\text { ribosome; Golgi apparatus; nuclear } \\
\text { envelope; nucleolus; } \\
\text { plasmodesma; proteasome } \\
\text { regulatory particle, base } \\
\text { subcomplex; ;spindle }\end{array}$ & $\begin{array}{l}\text { ATP binding;ATPase } \\
\text { activity;calmodulin } \\
\text { binding;identical protein } \\
\text { binding }\end{array}$ & $\begin{array}{l}\text { transitional } \\
\text { endoplasmic reticulum } \\
\text { ATPase;VCP }\end{array}$ \\
\hline 9 & SCCCLR1070F12.g & calnexin(UNIPROT) & -0.254 & 0.011 & -0.083 & 0.021 & 0.902 & $\begin{array}{l}\text { abscisic acid mediated signaling pathway; auxin mediated signaling pathway; } \\
\text { defense response to fungus; jasmonic acid mediated signaling pathway; MAPK } \\
\text { cascade; negative regulation of defense response; negative regulation of } \\
\text { programmed cell death; regulation of plant-type hypersensitive response; response } \\
\text { to bacterium; response to cold; response to heat; response to hydrogen peroxide; } \\
\text { systemic acquired resistance, salicylic acid mediated signaling pathway }\end{array}$ & $\begin{array}{l}\text { chloroplast; cytosol; endoplasmic } \\
\text { reticulum; Golgi apparatus; } \\
\text { mitochondrion; plant-type cell } \\
\text { wall; plasma membrane; } \\
\text { plasmodesma; vacuolar membrane }\end{array}$ & $\begin{array}{l}\text { calcium ion } \\
\text { binding;molybdenum ion } \\
\text { binding;unfolded protein } \\
\text { binding }\end{array}$ & calnexin;CANX \\
\hline 10 & SCSGST1072D03.g & $\begin{array}{l}\text { Calreticulin OS=Oryza sativa subsp. japonica } \\
G N=0 \text { s07g0246200 PE }=1 S V=2 \text { (UNIPROT) }\end{array}$ & -2.429 & -0.193 & -0.144 & 0.203 & 0.000 & $\begin{array}{l}\text { auxin mediated signaling pathway; calcium ion homeostasis ; cellular response to } \\
\text { nitrogen starvation; defense response signaling pathway, resistance gene- } \\
\text { independent; defense response to bacterium; plant-type hypersensitive response; } \\
\text { response to cadmium ion; response to heat; response to hydrogen peroxide; } \\
\text { response to salt stress; salicylic acid biosynthetic process; systemic acquired } \\
\text { resistance }\end{array}$ & $\begin{array}{l}\text { apoplast; chloroplast; cytosol; } \\
\text { endoplasmic reticulum membrane; } \\
\text { Golgi apparatus; mitochondrion; } \\
\text { plant-type cell wall; plasma } \\
\text { membrane; plasmodesma; } \\
\text { vacuolar membrane }\end{array}$ & $\begin{array}{l}\text { calcium ion } \\
\text { binding;molybdenum ion } \\
\text { binding;unfolded protein } \\
\text { binding }\end{array}$ & CALR;calreticulin \\
\hline
\end{tabular}




\section{Continuação Anexo 6.}

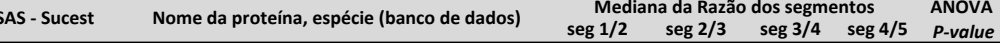

11 SCEPLR1051D05

calreticulin(UNIPROT)

$-0.08 \quad-0.395$

0.135

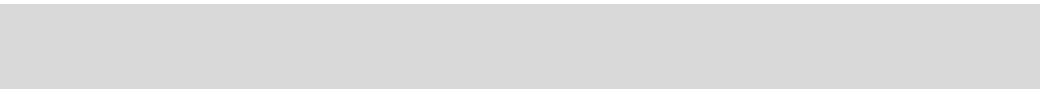

$12 \begin{array}{cccccc}\text { SCCCLR1048H09.g } \\ \begin{array}{c}\text { Catalase isozyme } 3 \text { OS=Zea mays GN=CAT3 PE=2 } \\ \text { SV=2 (UNIPROT) }\end{array} & -0.094 & 0.461 & 0.253 & 0.347 & 0.191\end{array}$ $S V=2$ (UNIPROT)
$0.094 \quad 0.461 \quad 0.253 \quad 0.347 \quad 0.000$

13 SCCCLB1023F09.

Cathepsin B (Fragment)(UNIPROT)

$-0.094$ 14 SCEQRT1025E03.g Cystatin-1 precursor (Cystatin I) (Corn kern $\begin{array}{lllll}0.270 & -0.534 & -0.226 & 0.237 & 0.546\end{array}$

15 SCCCLR1022B11.g cysteine protease 1 precursor [Zea mays](NCB)

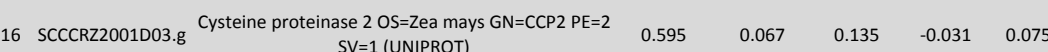

17 SCCCRZ3002G10.g $\begin{aligned} & \text { Cysteine proteinase inhibitor } 8 \text { OS=Oryza sativa } \\ & \text { subsp. japonica GN=0s03g0429000 PE=2 SV=1 }\end{aligned}$

(UNIPROT) Cilochrome b-cl complex subunit 7; Ubiquino cytochrome c reductase complex $14 \mathrm{kD}$ VIII;CR14(UNIPROT)

\author{
$\begin{array}{ccccc}-0.094 & 0.461 & 0.253 & 0.347 & 0.000\end{array}$
}

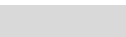

18 SCCCLR1001H04.g protein:Complex III SULU

$\begin{array}{lllll}0.597 & -0.200 & -0.389 & -0.252 & 0.007\end{array}$

0.007

0007

\begin{tabular}{|c|c|c|c|c|c|c|}
\hline 19 SCQGLR2025G04.g & Cytochrome b5(UNIPROT) & -0.046 & -0.360 & -0.224 & 0.091 & 0.534 \\
\hline 20 SCUTLR2023F06.g & $\begin{array}{l}\text { Cytochrome c OS=Oryza sativa subsp. japonica } \\
G N=C C-1 P E=1 \text { SV=1 (UNIPROT) }\end{array}$ & -1.783 & -0.101 & 0.356 & 0.188 & 0.072 \\
\hline 21 SCCCLR1080A05.g & $\begin{array}{l}\text { Cytochrome coxidase subunit } 6 \mathrm{~B} \\
\text { OS=Schizosaccharomyces pombe GN=cox12 PE=2 } \\
\text { SV=2 (UNIPROT) }\end{array}$ & -0.748 & - & - & - & 0.184 \\
\hline 22 SCUTLR1058A12.g & $\begin{array}{l}\text { Cytochrome c1-1, heme protein, } \\
\text { mitochondrial;Ubiquinol-cytochrome-c reductase } \\
\text { complex cytochrome c1 subunit 1; Cytochrome c-1- } \\
\text { 1; Cytochrome b-c1 complex subunit 4-1;; }\end{array}$ & 0.740 & 0.007 & 0.041 & -0.304 & 0.001 \\
\hline
\end{tabular}
GO processo biologico
auxin mediated signaling pathway; calcium ion homeostasis ;cellular response to
nitrogen starvation; defense response signaling pathway, resistance gene-
independent; defense response to bacterium; plant-type hypersensitive response; response to cadmium ion; response to heat; response to hydrogen peroxide;
response to salt stress; salicylic acid biosynthetic process; systemic acquired resistance

ammonium transport; cell redox homeostasis; cellular cation homeostasis; cellular response to nitrogen starvation; cellular response to phosphate starvation; cellul mediated transport; fotty acid beta oxidation; hydrogen peroxide catabolic price-ss; negative regulation of programmed cell death; nucleotide transport: photoperiodism, photorespiration; protein import into peroxisome matrix; regulation of ion transport; regulation of plant-type hypersensitive response;
response to abscisic acid stimulus; response to cadmium ion; response to cold response to abscisic acid stimulus; response to cadmium ion; response to cold; esponse to cyclopentenone; starch metabolic process; systemic acquired
resistance; toxin catabolic process; tryptophan catabolic process

cell growth; cell morphogenesis fatty acid beta-oxidation; Golgi vesicle transporti proteolysis; regulation of catalytycic activity; response to abiotic stimulus; r response to inorganic substance; response to oxygen-containing compound ;response to stress cellular response to cold; cellular response to heat; cellular response to water deprivation; hyperosmotic response; response to cadmium ion; response to
oxidative stress; response to wounding cell wall pectin metabolic process; cysteine biosynthetic process; defense response to fungus, incompatible interaction; developmental programmed cell death; gibberellic acid mediated signaling pathway; gibberellin biosynthetic process
curonoxylan metabolic process; Golgi organization; hydrogen peroxide catabolic ; glucuronoxylan metabolic process; Golgi organization; hydrogen peroxide catabolic
process; hyperosmotic salinity response ;leaf senescence; plant-type cell wall process; hyperosmotic salinity response ;leaf senescence; plant-type cell wall
cellulose metabolic process; proteolysis; regulation of meristem growth; response to cadmium ion; response to ethylene stimulus; response to water deprivation; root milum ion; response to enter stimulus; response to water depriv
hair elongation; water transport: yylan biosynthetic process

calcium ion transport; cell wall polysaccharide metabolic process; cellular biosynthetic process; defense response to fungus; Golgi organization; hydrogen peroxide catabolic process; hyperosmotic salinity response;organ developmen ganic substance biosynthelic process, proteolysis, response to cadmium ion gibberellin stimulus; water transport
gitim

cellular response to stress; response to inorganic substance; response to temperature stimulus
ters

erobic respiration; glycolysis; mitochondrial electron transport, ubiquinol to

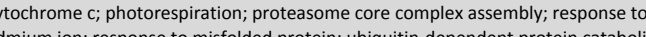
kane biosynthetic process; cellular lipid catabolic process; defense response to bacterium; glucosinolate biosynthetic process; indoleacetic acid biosynthetic
process; lateral root formation; nitrate assimilation; nitric oxide biosynthetic procss; response to symbiotic fungus; root hair elongation; sterol biosynthet process

GO componente celular

GO função molecul

informações do kegg

poplast; chloroplast; cytosol;

Goplgi apparatusus mitochondrane; plant-type cell wall; plasma
membrane; plasmodesma;

a

apoplast; cell wall; cytosolic

ribosome; mitochondrion; nucle

peroxisome; plant-type vacuole
membrane; plasma membrane;

$$
\text { plasmodesma }
$$

cytosol; extracellular region; vacuole

calcium ion

inding;molybdenum ion binding; unfolded protein

CALR;calreticuli

arginine transmembrane transporter activity;catalase activity; cationic amino acid
transmembrane transporte

activity; cobalt ion

binding;heme binding;L-

glutamate transmembrane transporter activity:-l-ysine activity:protein binding

cysteine-type endopeptidase

cell wall; cytosol; endoplasmic

cobalt ion binding; cysteinevacuolar membrane

activity

anchored to membrane; apoplast;

cell wall; chloroplast; cytosol; calcium ion binding; cysteine-

doplasmic reticulum; nucleus; type peptidase activity; protein

assodesma; senescence-

binding

poplast; cell wall; chloroplast;

clast; calcium ion binding;cysteine- cathepsin $\mathrm{H}$

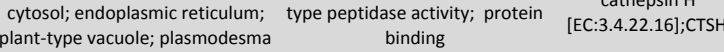

cell wall; cytosol; membrane; $\quad$ cysteine-type endopeptidase
plasmodesma; vacuole plasmodesma; vacuole inhibitor activity

mitochondrial respiratory chain $\quad$ ubiquinol-cytochrome-c $\quad$ QCR7; ;ubiquinolmedilit; plastid; vacuolar ar activity
membrane

chloroplast outer membrane;

heme binding;nitrate reductase

cytosol; endoplasmic reticulum $\quad$ (NADH) activity; protein

membrane; mitochondrion; plasma binding;sphingolipid dela 8

membrane ; vacuolar membrane desaturase activity

cytosol; Golgi apparatus; copper ion binding; electron $\begin{gathered}\text { mitochondrion; vacuolar } \\ \text { membrane }\end{gathered}$
carrier activity; heme bindin
iron ion binding

cell proliferation; glucose catabolic process

oxidation-reduction process; phosphatidylinositol biosynthetic process; photorespiration; response to salt stress

chloroplast thylakoid membrane; copper ion binding: cytochro mitochondrion coxidase activity obic respiration; pentose-phosphate shunt; photorespiration; proteasome core response to salt stress; electron transporter, transferring electrons with

transferring electrons within
CoQH2-cytochrome c reductase complex activity; heme binding iron ion binding; $p$
binding 


\section{Continuação Anexo 6.}

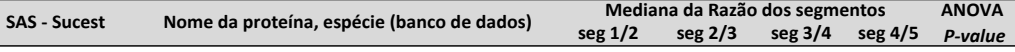

GO processo biológico
cell development; cell wall organization or biogenesis; defense response to
acterium; Golgi organization; hydrogen peroxide catabolic process; hyperosmotic

bacterium; Golgi organization; hydrogen peroxide catabolic process; hyperosmotic polysaccharide metabolic process; proteolysis; response to cadmium ion; response to desiccation; response to hormone stimulussing; water transport

23 SCJFLR1013A09.g drought and cold response(UNIPRO)

gluconeogenesis; glycolysis; pentose-phosphate shunt; photorespiration; response light stimulus; response to salt

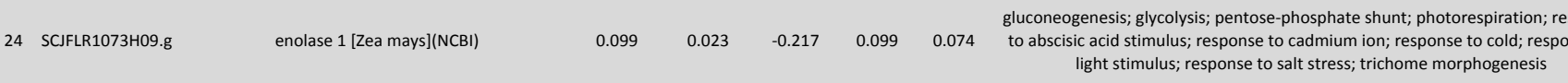
25 SCCCRZ1002F06.g Enolase 2 OS=Zea mays GN=ENO2 PE=2 SV=1

$-0.009$

26 SCCCLR1070G05.g $\begin{gathered}\text { Enolase-phosphatase E1 (2,3-diketo-5-methylthio- } \\ \begin{array}{c}\text { 1-phosphopentane phosphatase) (MASA } \\ \text { homolog)(UNIPROT) }\end{array}\end{gathered}$

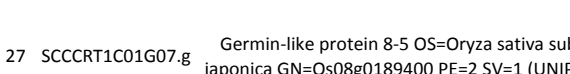

$\begin{array}{lllll}0.785 & 0.529 & 0.339 & -0.019 & 0.015\end{array}$

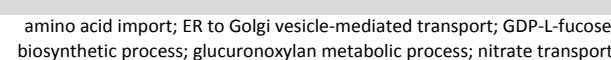
regulation of root development; response to cold: response to endoplasmic reticulum stress; response to nitrate ;response to salt stres; xylan biosynthetic process

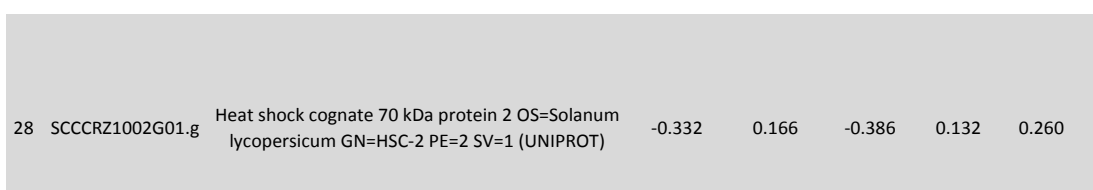

autophagy; defense response to bacterium; defense response to fungus: endoplasmic reticulum unfolded protein response; ER-associated protein catabolic
process; gluconeogenesis; heat acclimation :hyperosmotic salinity response negative regulation of seed germination; protein retention in ER lumen p prote targeting to chloroplast; response to cadmium ion; response to cold; response to high light intensity; response to hydrogen peroxide; response to virus; response to
water deprivation; salicylic acid biosynthetic process; systemic acquired resistance calcium-mediated signaling; cellular response to calcium ion; de-etiolation; defense response to bacterium, incompatible interaction; heat acclimation; organic
substance biosynthetic process; protein secretion, protein stabilization

29 SCJLR1011E03.g $\begin{aligned} & \text { Heat shock protein } 81-1 \text { OS=Oryza sativa subss } \\ & \text { japonica GN=HS81-1 PE=2 SV=2 (UNIPROT) }\end{aligned}$

$-0.229$

0.061

$-0.253$

$-0.009 \quad 0.85$

substance biosynthetic process; protein secretion; protein stabilization; regulation of
meristem growth; regulation of meristem structural organization, respunse to cadmium ion; response to chlorate; response to cold; response to hydrogen
peroxide; response to mechanical stimulus; response to salt stress; response to water deprivation

calcium-mediated signaling; cellular response to calcium ion; de-etiolation; defense clcium-mediated signaling; cellular response to calcium ion; de-etiolation; defen
response to bacterium, incompatible interaction; heat acclimation; organic response to bacterium, incompatible interaction; heat acclimation; organic
substance biosynthetic process; protein secretion; protein stabilization; regulation

30 SCCCIR2CO2F10 g Heat shock protein $81-3$ OS=Oryza sativa subsp. JaPonica GN=HSP81-3 PE=2 SV=2 (UNIPROT)

$\begin{array}{lllll}-3.972 & 0.161 & -0.613 & 0.306 & 0.003\end{array}$

meristem growth; regulation of meristem structural organization; response to
metration cadmium ion; response to chlorate,response to cold; response to hydrogen
peroxide; response to mechanical stimulus; response to salt stress; response to water deprivation

GO componente celul

informações do kegg vacuole

ium ion binding:cystein

cathepsin $F$

poplast; chloroplast stroma

tochondrial envelope; nucle phosphopyruvate hydratase
complex; plasma membrane, plasmodesma

apoplast; chloroplast stroma;

itochondrial envelope; nucleus; phosphopyruvate hydratas plasmodesma protein binding
pactivatis cathepsin F
[EC:3.4.22.41];CTSF

copper ion binding:DNA binding;magnesium ion ENO;enolase Ending; phosphopyruvate $\quad$ EC:4.2.1.11]
[ hydratase activity

(1)

\section{copper ion binding;DNA} binding;magnesium ion
inding;phosphopyruvate hydratase activity

chloroplast stroma; cytosol

acireductone synthase activity;

apoplast; extracellular matrix;nucleus;plant-type cell manganese ion membrane;plasmodesma apoplast; cell wall; chloroplast envelope; cis-Golgi network; cytosolic ribosome; endoplasmic
eticulum lumen; Golgi apparatus integral to membrane; mediator complex; mitochondrial matrix; uclear matrix; nucleolus; plasm membrane; plasmodesma; a envelope;chloroplast
entatis stroma; cytosol;endoplasmic reticulum;Golgi apparatus; mitochondrion;nucleolu s;plasma membrane;plasmodesma;vacuolar apoplast;cell wall;;chloroplast envelope; chloroplast stroma;cytosol; endoplasm s;plasma membrane;plasmodesma;vacuolar jasmonic acid biosynthetic process; leaf senescence; oxidation-reduction process; xylipin metabolic process; ;response to cadmium ion; response to fungus;response to hormone stimulus; response to ozone; response to salicylic acid stimulus;

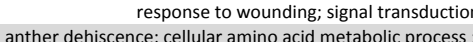

cytosol;peroxisome binding;nutrient reservor activity;oxalate oxidase activity

ATP binding;:KDEL sequence binding;protease
binding.receptor heat shock 70kDa binding;zinc ion binding

\section{ATP binding;:ATPase \\ haperone Htp} binding compound metabolic process; coenzyme metabolic pric ass defense response to
bacterium, incompatible interaction; growth; jasmonic acid biosynthetic process ; Iateral root formation ;lipid biosynthetic process; lipid oxidation; localization, membrane disassembly; negative regulation of defense response to insect; organic fungus;response to herbivore; response to jasmonic acid stimulus; response to

s;response to herbivore; response to jasmonic acid stimulus; respon
ozone; response to water deprivation, response to wounding

ENO;enolase
[EC:4.2.1.11]

DEP1;methylthioribul

se 1-phosphate

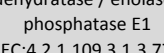

31 SCBGRT3075F07.

Jasmonate(UNIPROT)

$\begin{array}{lllll}0.628 & 0.159 & -0.099 & -0.106 & 0.000\end{array}$ 


\section{Continuação Anexo 6.}

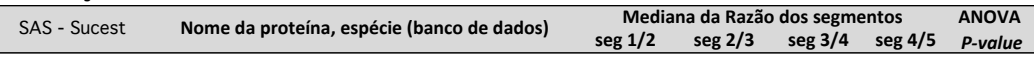

abscisic acid mediated signaling pathway; hyperosmotic salinity response
;indoleacetic acid biosynthetic process; jasmonic acid biosynthetic process ; jasmonic
tryptophan catabolic process

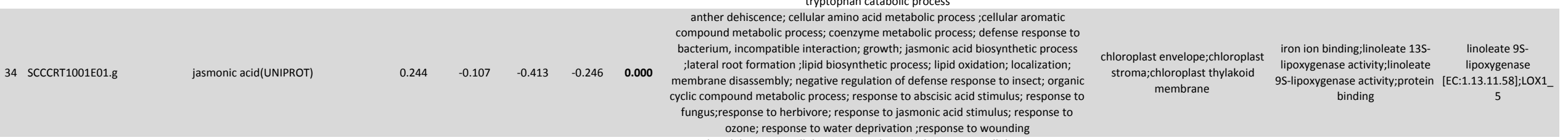
ozone; response to water deprivation; ;response to wounding rense anther dehiscence; cellular amino acid metabolic process ; cellular aromatic bacterium incompatible interaction; growth. jasmonic acid biosyse response to -lateral root formation; ;lipid biosynthetic process; lipid oxidation; localization; membrane disassembly; negative regulation of defense response to insect; organic cyclic compound metabolic process; response to abscisic acid stimulus; response to fungus;response to herbivore; response to jasmonic acid stimulus; response to ozone; response to water deprivation; response to wounding

\begin{tabular}{|c|c|c|c|c|c|c|}
\hline 6 SCUTLR2030B03.g & jasmonic acid(UNIPROT) & 0.068 & 0.227 & 0.033 & -0.407 & 0.062 \\
\hline
\end{tabular}

anther dehiscence; cellular amino acid metabolic process; cellular aromatic bacterium, incompatible insteraction; growth; jasmonic acid biosynthetic process ;lateral root formation; ;ipid biosynthetic process; lipid oxidation; localization; itis cyclic compound metabolic process; response to abscisic acid stimulus; response to fungus, response to herbivore; response to jasmonic acid stimulus, response to cellular modified amino acid biosynthetic process; cold acclimation; embryo development ending in seed dormancy; Golgi organization; ;hydrogen peroxide catabolic processs ;hydrogen peroxide mediated signaling pathway; hyperosmotic catabolic process; response to cadmium ion; response to endoplasmic reticulum stress; response to heat; response to salt stress; ubiquitin-dependent protein

stress; response to heat; response to salt stress;ubiquitin-dependent protein membrane; plasmodesm
catabolic process; water transport
membrane

GO componente celular

GO função molecular

informações do kegg

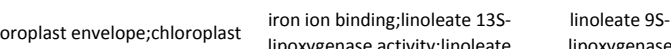

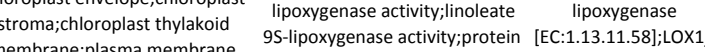
binding binding

$\begin{array}{lll}\text { chloroplast envelope;chloroplast } & \text { iron ion binding;linoleate 13S- } & \text { linoleate 9S- } \\ \text { lipoxygenase activity/linoleate } & \text { lipoxygenase }\end{array}$ $\begin{array}{ccc} & \\ & \end{array}$

bs

$$
\text { binding }
$$

\section{cell wall;chloroplast
envelope;chloroplast}

membrane; cytosol; Golgi

pparatus;mitochondrion; peroxiso

mal membrane;plasma

eme binding;--ascorbate membrane

cell communication; cell wall polysaccharide catabolic process; cellular response to simulus; defense response to fungus; defense response to nematode; hyperosmotic

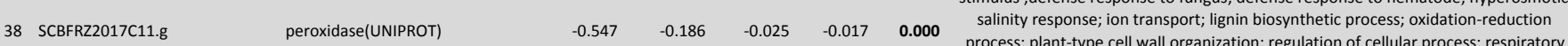
process; plant-type cell wall organization; regulation of cellular process; respiratory
burst; response to cold; response to desiccation; response to organic substance;

response to oxidative stress

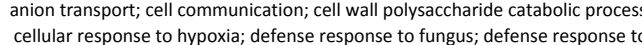
nematode; hyperosmotic salinity response; lignin biosynthetic process; mucilage extrusion from seed coat; nitrogen compound transport; organic substance

39 SCCCAD1001C08.g

peroxidase(UNIPROT)

0.79

0.464

$0.081-0.043$

transport; oxidation-reduction process; plant-type cell wall organization; regulaton of programmed cell death; respiratory burst; response to cold; response to desiccation; response to nitrogen compound; response to organic subst
response to oxidative stress; transition metal ion transport response to oxidative stress; transition metal ion transport

response to hypoxia; defense response to fungus; hyperosmotic salinity esponse;ion transport; lignin biosynthetic process; organ development; oxidationreduction process; primary metabolic process; regulation of cellular process;
respiratory burst; response to cold; response to desiccation; response to organic respiratory burst; response to cold; response to desiccation; response to organic
substance; response to oxidative stress; single-organism developmental process;

apoplast;Golgi

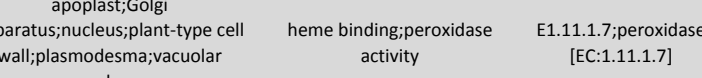
membrane

apoplast; cytosol;Golg apparatus;nucleus;plant-type cell heme binding;peroxidase E1.11.1.7; peroxidase activity; protein binding [EC:1.11.1.7] membran 


\section{Continuação Anexo 6.}

\section{SAS - Sucest

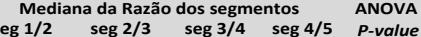

41 SCCCCL300зво2.b

peroxidase(UNIPROT)

$\begin{array}{llll}-0.211 & -0.317 & -0.441 & 0.93\end{array}$

\begin{tabular}{|c|c|c|c|}
\hline SCCCCL4012A01.g & peroxidase(UNIPROT) & -1.058 & 0.090 \\
\hline
\end{tabular}

peroxidase(UNIPROT)

$-0.487 \quad-0.381$

0.001

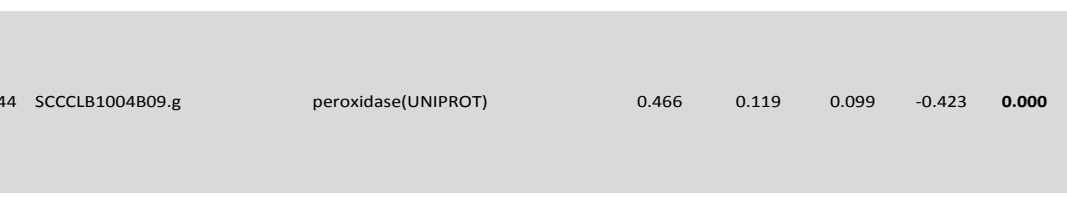

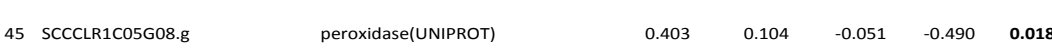

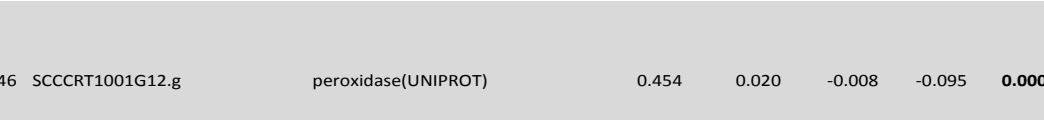

47 SCEPRZ1011A06

peroxidase(UNIPROT)

0.074

$-0.461$

$-0.071 \quad-0.052$

SCEQRT1024D03.

peroxidase(UNIPROT)

49 SCEQRT1024F02.g

peroxidase(UNIPROT)

$\begin{array}{lllll}0.423 & 0.101 & -0.132 & -0.423 & 0.000\end{array}$ aromatic compound biosynthetic process; catabolic process; cellular response to
hypoxia; defense response; flower development; ion transport; organ development; organic cyclic compound biosynthetic process; oxidation-reduction process; phenylpropanoid metabolic process; primary metabolic process; regulation of biosynthetic process; tissue development

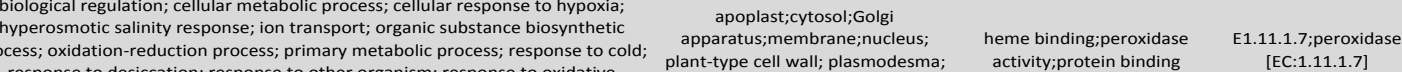
response to desiccation; response to other organism; response to oxidative plant-type cell wall; pla

GO componente celul

GO função molecular

informações do kegg stress;root development; tissue development
on transport; cell communication; cellular response to hypoxia; defense response lo fungus; defense response to nematode; lignin metabolic process; nitrogen
compound transport: organonitrogen compound metabolic process; oxidation reduction process; plant-type cell wall organization; regulation of celluluar process respiratory burst; response to endogenous stimulus; response to nitrogen
compound; response to organic substance; response to oxidative stress; response to oxygen-containing compound; transition metal ion transport; trichoblast differentiation
brassinosteroid biosynthetic process; cell wall polysaccharide catabolic process; cellular response to hypoxia; cellular response to iron ion starvation; defense
response to fungus; defense response to nematode; developmental growth; flower development; hyperosmotic salinity response; iron ion transport; lignin biosynthetic process ; mucilage extrusion from seed coat; nitrate transport; oxidation-reduction

cell wall polysaccharide catabolic process; cellulalr response to hypoxia; defense
response to bacterium; defense response to fungus: defense responss to lignin biosn thetic process; lignin biosynthetic process; mucilage extrusion from seed coat; negative regulation
of growth; oxidation-reduction process; pathogen-associated molecular pattern dependent induction by symbiont of host innate immune response; reactive oxygen
species metabolic process; response to light stimulus; response to oxidative stress;
response to salt stress; unidimensional cell growth

cell wall polysaccharide catabolic process; cellular response to hypoxia; defense to nematode, process; pathogen-associated molecular pattern dependent induction by symbiont of host innate immune response; reactive oxygen species metabolic process;
response to light stimulus; response to oxidative stress; unidimensional cell growth cell wall polyssccharide cas bic process; cellular response to hypoxia defense cell wall polysaccharide catabolic process; cellular response to hypoxia; defense
response to bacterium; defense response to fungus; defense response to nematode ; flower development; lignin biosynthetic process; mucilage extrusion from seed coat; negative regulation of growth;oxidation-reduction process; pathogenimmune response; reactive oxygen species metabolic process; response to ligh immune response; reactive exysen species metabolic process; response to light
stimulus; response to oxidative stress; response to salt stress; response to zinc ion;

apoplasticytosol; Gol

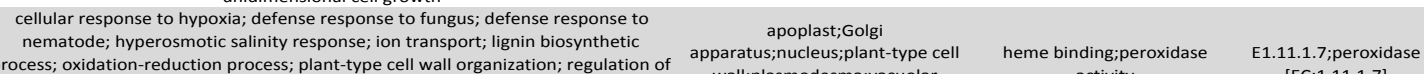
cellular process; respiratory burst; response to cold; response to desiccation;
cestions response to oxidative stress; trichoblast differentiation brassinosteroid biossnnthetic process; $;$ cellular rersponse to i iron ion starvation;
defense response to fungus; developmental growth; hyperosmotic salinity respoons iron ion transport; lignin biosynthetic process; nitrate transport; oxidation-reduction process; plant-type cell wall organization; post-embryonic development; post-
embryonic organ development; regulation of cellular process;respiratory burst;
response to cold; response to desiccation; response to nitrate; response to oxidative stress; root hair cell differentiation
cell wall polysaccharide catabolic process; cellular response to hypoxia; defense response to fungus; defense response to nematode; flower development;
rester

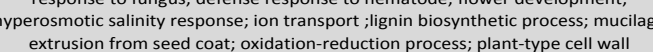

apoplast;:endoplasmic
reticulum;Golgi

heme binding;peroxidase
activity:transferase activity,
transferring glycosyl groups
[EC: 7 :1.11.1.1.7] t-type cell wall;; plasmodesma

[EC:1.11.1.7]

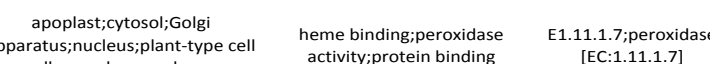
wall;; ivacuolar membran
menting

activity;protein bindine

apoplast:cytosol:Gols

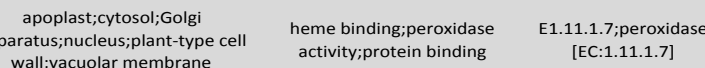
(1.2.1.7)

apoplast; cytosol;Golgi
hemaratus;nucleus;;lant-type cell
heme binding;peroxidase
activity:protein binding wall:;vacuolas membran

wall;plasmodesma;vac

\section{apoplast; endoplasmic}

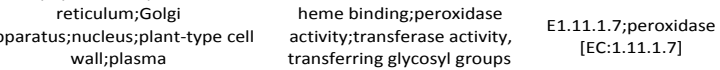
burst; response to cold; response to desiccation; response to nitrate; response to oxidative stress; root hair cell differentiation extrusion from seed coat; oxidation-reduction process; plant-type cell wall
organization; regulation of cellular processs respiratorr burst; response to cold;
response to desiccation; response to oxidative stress

\section{apoplast; ;ytosol;Golg wall; vacuoolar membran \\ heme binding;peroxidase
activity
E1.11.1.7pperoxidase
$[$ EC:1.11.1.7]}

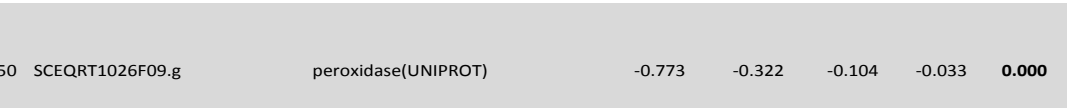




\section{Continuação Anexo 6.}

\begin{tabular}{|c|c|c|c|c|c|c|c|c|c|c|}
\hline SAS- Sucest & Nome da proteína, espécie (banco de dados) & $\begin{aligned} \text { Media } \\
\operatorname{seg} 1 / 2\end{aligned}$ & $\begin{array}{l}\text { la da Razấ } \\
\operatorname{seg} 2 / 3\end{array}$ & $\begin{array}{c}\text { dos segm } \\
\text { seg } 3 / 4\end{array}$ & $\begin{array}{l}\text { ntos } \\
\text { seg } 4 / 5\end{array}$ & $\begin{array}{l}\text { ANOVA } \\
\text { P-value }\end{array}$ & GO processo biológico & GO componente celular & GO função molecular & informações do kegg \\
\hline 51 SCEQRT1028D12.g & peroxidase(UNIPROT) & -0.134 & -0.074 & -0.025 & -0.509 & 0.201 & $\begin{array}{l}\text { cell wall organization or biogenesis; cellular response to stress; organ development; } \\
\text { organic substance biosynthetic process; oxidation-reduction process; } \\
\text { phenylpropanoid metabolic process; primary metabolic process; response to abiotic } \\
\text { stimulus;response to inorganic substance; response to oxidative stress }\end{array}$ & $\begin{array}{l}\text { cell wall;:extracellular } \\
\text { region;membrane;vacuole }\end{array}$ & $\begin{array}{l}\text { heme binding;peroxidase } \\
\text { activity }\end{array}$ & $\begin{array}{l}\text { E1.11.1.7;peroxidase } \\
\text { [EC:1.11.1.7] }\end{array}$ \\
\hline 52 SCEQRT1028H09.g & peroxidase(UNIPROT) & -0.279 & -0.187 & -0.241 & -0.442 & 0.086 & oxidation-reduction process; response to oxidative stress & & $\begin{array}{l}\text { heme binding; peroxidase } \\
\text { activity }\end{array}$ & $\begin{array}{c}\text { E1.11.1.7;peroxidase } \\
\text { [EC:1.11.1.7] }\end{array}$ \\
\hline 53 SCEQRT2030A04.g & peroxidase(UNIPROT) & 0.565 & 0.138 & 0.026 & -0.468 & 0.002 & $\begin{array}{l}\text { brassinosteroid biosynthetic process; cellular response to hypoxia; cellular response } \\
\text { to iron ion starvation; developmental growth; hyperosmotic salinity response; iron } \\
\text { ion transport;: i ignin biosynthetic process; nitrate transport; oxidation-reduction } \\
\text { process; plant-type cell wall organization; response to cold; response to desiccation; } \\
\text { response to nitrate; response to other organism; response to oxidative stress; root } \\
\text { hair cell differentiation; xylan metabolic process }\end{array}$ & $\begin{array}{l}\text { apoplast; cytosol;:endoplasmic } \\
\text { reticulum;Golgi } \\
\text { apparatus; cembrane;nucleus;plan } \\
\text { t-type cell wall;plasmodesma }\end{array}$ & $\begin{array}{l}\text { heme binding;peroxidase } \\
\text { activity;protein } \\
\text { binding,transferase activity, } \\
\text { transferring glycosyl groups }\end{array}$ & $\begin{array}{l}\text { E1.11.1.7; peroxidase } \\
\text { [EC:1.11.1.7] }\end{array}$ \\
\hline 54 SCEZRT2019F10.g & peroxidase(UNIPROT) & -1.211 & - & - & - & 0.099 & $\begin{array}{l}\text { brassinosteroid biosynthetic process; cellular response to hypoxia; cellular response } \\
\text { to iron ion starvation; developmental growth; hyperosmotic salinity response; iron } \\
\text { ion transport;: Iignin biosynthetic process; nitrate transport; oxidation-reduction } \\
\text { process; plant-type cell wall organization; response to cold; response to desiccation; } \\
\text { response to nitrate; response to other organism; response to oxidative stress; root } \\
\text { hair cell differentiation; xylan metabolic process }\end{array}$ & $\begin{array}{c}\text { apoplast:endoplasmic } \\
\text { reticulum;Golgi } \\
\text { apparatus;nucleus;plant-type cell } \\
\text { wall;plasma } \\
\text { membrane;plasmodesma; ;vacuole }\end{array}$ & $\begin{array}{l}\text { heme binding;peroxidase } \\
\quad \text { activity;protein } \\
\text { binding:transferase activity, } \\
\text { transferring glycosyl groups }\end{array}$ & $\begin{array}{l}\text { E1.11.1.7;peroxidase } \\
\text { [EC:1.11.1.7] }\end{array}$ \\
\hline 55 SCJFLR1035D05.g & peroxidase(UNIPROT) & 0.825 & 0.463 & 0.103 & -0.135 & 0.000 & oxidation-reduction process; response to oxidative stress & & $\begin{array}{l}\text { heme binding;peroxidase } \\
\text { activity }\end{array}$ & $\begin{array}{c}\text { E1.11.1.7;peroxidase } \\
\text { [EC:1.11.1.7] }\end{array}$ \\
\hline 56 SCJFRZ2013F04.g & peroxidase(UNIPROT) & 0.395 & -0.351 & 0.133 & 0.162 & 0.780 & $\begin{array}{l}\text { cell communication; cellular response to stimulus; defense response to fungus; } \\
\text { defense response to nematode; developmental growth; hyperosmotic salinity } \\
\text { response; inorganic anion transport; lignin metabolic process; nitrogen compound } \\
\text { transport; oxidation-reduction process; plant-type cell wall organization; primary } \\
\text { metabolic process;; regulation of cellular process; respiratory burst; response to cold; } \\
\text { response to desiccation; ;response to nitrogen compound; response to oxidative } \\
\text { stress; root hair cell differentiation; transition metal ion transport }\end{array}$ & $\begin{array}{c}\text { apoplast;Golgi } \\
\text { apparatus;nucleus;plant-type cell } \\
\text { wall;lasma } \\
\text { membrane;plasmodesma }\end{array}$ & $\begin{array}{l}\text { heme binding;peroxidase } \\
\text { activity }\end{array}$ & $\begin{array}{l}\text { E1.11.1.7; peroxidase } \\
\text { [EC:1.11.1.7] }\end{array}$ \\
\hline 57 SCRFRZ3054A09.g & peroxidase(UNIPROT) & -0.421 & 0.052 & 0.113 & -0.472 & 0.282 & & & & \\
\hline 58 SCRLAD1042E05.g & peroxidase(UNIPROT) & 0.603 & 0.471 & 0.248 & -0.185 & 0.008 & cell wall organization; cellular macromolecule metabolic process; immune response & $\begin{array}{l}\text { anchored to plasma } \\
\text { membrane;plasmodesma }\end{array}$ & $\begin{array}{l}\text { chitin binding;peptidoglycan } \\
\text { binding }\end{array}$ & \\
\hline 59 SCSBRZ2021C03.g & peroxidase(UNIPROT) & -0.244 & -0.347 & 0.138 & -0.339 & 0.027 & $\begin{array}{l}\text { defense response to bacterium; defense response to fungus; defense response to } \\
\text { nematode; hyperosmotic salinity response; ion transport; lignin biosynthetic } \\
\text { process; oxidation-reduction process; pathogen-associated molecular pattern } \\
\text { dependent induction by symbiont of host innate immune response; primary } \\
\text { metabolic process;; reactive oxygen species metabolic process; response to cold; } \\
\text { response to desiccation; response to light stimulus; response to oxidative stress; } \\
\text { root development; tissue development; unidimensional cell growth }\end{array}$ & $\begin{array}{l}\text { apoplast;;ytosol;Golgi } \\
\text { apparatus; } ; \text { ucleus;plant-type cell } \\
\text { wall;;plasmodesma;;vacuolar } \\
\text { membrane }\end{array}$ & $\begin{array}{l}\text { heme binding;peroxidase } \\
\text { activity;protein binding }\end{array}$ & $\begin{array}{c}\text { E1.11.1.7;peroxidase } \\
\text { [EC:1.11.1.7] }\end{array}$ \\
\hline 60 SCSFCL6068C11.g & peroxidase(UNIPROT) & -0.073 & -0.370 & -0.008 & -0.309 & 0.492 & $\begin{array}{l}\text { cell wall polysaccharide catabolic process; cellular response to hypoxia; defense } \\
\text { response to fungus; hyperosmotic salinity response;ion transport; lignin biosynthetic } \\
\text { process; mucilage extrusion from seed coat; oxidation-reduction process;regulation } \\
\text { of cellular process; respiratory burst; response to cold; response to desiccation; } \\
\text { response to oxidative stress }\end{array}$ & $\begin{array}{l}\text { apoplast;membrane;nucleus;plant- } \\
\text { type cell } \\
\text { wall;plasmodesma;vacuole }\end{array}$ & $\begin{array}{l}\text { heme binding;peroxidase } \\
\text { activity }\end{array}$ & $\begin{array}{l}\text { E1.11.1.7; peroxidase } \\
\text { [EC:1.11.1.7] }\end{array}$ \\
\hline 61 SCSGRT2063H01.g & peroxidase(UNIPROT) & -0.790 & 0.081 & 0.177 & 0.212 & 0.007 & $\begin{array}{l}\text { aromatic compound biosynthetic process; catabolic process; cell wall organization or } \\
\text { biogenesis; cellular response to stress; defense response; flower development;ion } \\
\text { transport; lignin metabolic process; organ development; organic cyclic compound } \\
\text { biosynthetic process; oxidation-reduction process;primary metabolic process; } \\
\text { regulation of growth;response to chemical stimulus; response to nematode; } \\
\text { response to oxidative stress; single-organism biosynthetic process; tissue } \\
\text { development }\end{array}$ & $\begin{array}{l}\text { membrane;plant-type cell } \\
\text { wall;plasmodesma;vacuole }\end{array}$ & $\begin{array}{l}\text { heme binding;peroxidase } \\
\text { activity }\end{array}$ & $\begin{array}{l}\text { E1.11.1.7; peroxidase } \\
\text { [EC:1.11.1.7] }\end{array}$ \\
\hline 62 SCUTHR1063E12.g & peroxidase(UNIPROT) & 0.606 & -0.480 & 0.088 & -0.175 & 0.001 & $\begin{array}{l}\text { cell wall polysaccharide catabolic process; cellular response to hypoxia; defense } \\
\text { response to fungus; hyperosmotic salinity response;ion transport; lignin biosynthetic } \\
\text { process; mucilage extrusion from seed coat; oxidation-reduction process;;regulation } \\
\text { of cellular process; respiratory burst; response to cold; response to desiccation; } \\
\text { response to oxidative stress }\end{array}$ & $\begin{array}{c}\text { apoplast; cytosol;Golgi } \\
\text { apparatus;nucleus;plant-type cell } \\
\text { wall;;vacuolar membrane }\end{array}$ & $\begin{array}{l}\text { heme binding;peroxidase } \\
\text { activity;protein binding }\end{array}$ & $\begin{array}{l}\text { E1.11.1.7;peroxidase } \\
\text { [EC:1.11.1.7] }\end{array}$ \\
\hline
\end{tabular}


Continuação Anexo 6.

\begin{tabular}{lllllll} 
SAS - Sucest & Nome da proteína, espécie (banco de dados) & \multicolumn{4}{c}{ Mediana da Razão dos segmentos } & ANOVA \\
$\operatorname{seg} 1 / 2$ & $\operatorname{seg} 2 / 3$ & seg $3 / 4$ & seg $4 / 5$ & $P$-value \\
\hline & & & & & &
\end{tabular}

63 SCVPLB1020D03.

peroxidase(UNIPROT)

0.402

0.102

0.112

$120 \quad 0.024$

\begin{tabular}{|c|c|c|c|c|c|}
\hline & peroxidase(UNIPROT) & 0.351 & 0.173 & 0.249 & -0.185 \\
\hline
\end{tabular}

65 SCSGLR1045G11.g $\quad \begin{aligned} & \text { Probable calcium-binding protein CML7 } \\ & \text { (Calmodulin-like protein 7)(UNIPROT) }\end{aligned}$

$\begin{array}{lllll}0.365 & -0.329 & -0.003 & 0.372 & 0.637\end{array}$

Probable cytochrome c biosynthesis

0.397

$\begin{array}{llllllll}67 & \text { SCVPRT2080B07.g } & \text { Protease inhibitor(UNIPROT) } & 0.731 & 0.229 & 0.426 & -0.086 & 0.000\end{array}$

$\begin{array}{llllllll}67 & \text { SCVPRT2080B07.g } & \text { Protease inhibitor(UNIPROT) } & 0.731 & 0.229 & 0.426 & -0.086 & 0.000\end{array}$

$\begin{array}{llllllll}67 & \text { SCVPRT2080B07.g } & \text { Protease inhibitor(UNIPROT) } & 0.731 & 0.229 & 0.426 & -0.086 & 0.000\end{array}$

0.033

$0.191 \quad-0.038$

$\begin{array}{llllllll}67 & \text { SCVPRT2080B07.g } & \text { Protease inhibitor(UNIPROT) } & 0.731 & 0.229 & 0.426 & -0.086 & 0.000\end{array}$

68 SCLRT2051G07.g

Protease inhibitors(UNIPROT)

$-0.76$

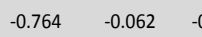

$0.316 \quad 0.000$

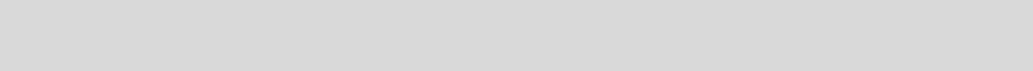

69 SCVPRT2073B04.g

Protease inhibitors(UNIPROT)

$-0.684 \quad-0.207$

\begin{tabular}{|c|c|c|c|c|c|c|}
\hline 70 SCEZLB1007G10.g & $\begin{array}{l}\text { Serine carboxypeptidase } 2 \text { OS=Triticum aestivum } \\
G N=C B P 2 P E=1 S V=2 \text { (UNIPROT) }\end{array}$ & -0.446 & 0.147 & -0.284 & -0.187 & 0.838 \\
\hline 71 SCEZRZ3016H03.g & $\begin{array}{l}\text { Serine carboxypeptidase Il-3 OS=Hordeum vulgare } \\
\qquad N=C X P ; 2-3 P E=2 S V=1 \text { (UNIPROT) }\end{array}$ & & - & - & -0.198 & 0.648 \\
\hline 72 SCBFRZ2017A10.g & $\begin{array}{l}\text { Serine carboxypeptidase-like OS=Oryza sativa } \\
\text { subsp. japonica GN=CBP31 PE=2 SV=2 (UNIPROT) }\end{array}$ & -0.904 & 0.351 & 0.084 & -0.101 & 0.036 \\
\hline 73 SCCCLR1C01H05.g & $\begin{array}{l}\text { Similar to Hordeum vulgare carboxypeptidase D } \\
\text { (Putative carboxypeptidase D)(UNIPROT) }\end{array}$ & -0.105 & -0.209 & -0.323 & -0.179 & 0.307 \\
\hline
\end{tabular}

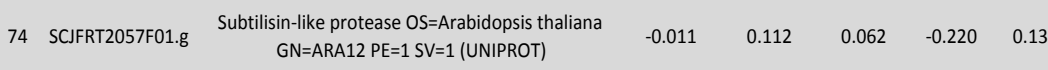
98

\section{A}

GO processo biológico
anther development; cell wall organization or biogenesis;defense response to
bacterium; defense response to fungus; defense response to
anther development; cell wall organization or biogenesis;defense response to
bacterium; defense response to fungus; defense response to nematode; hyperosmotic salinity response; ion transport;negative regulation of growth; organic substance biosynthetic process; oxidation-reduction process; pathogen-associated molecular pattern dependent induction by symbiont of host innate immune response; primary metabolic process; reactive oxygen species desiccation; response to light stimulus; response to oxidative stress; unidimensiona chesponse to cellular metabolic process; organ development; organic substance metabolic process;oxidation-reduction process; primary metabolic process; response to abiotic stimulus; response to inorganic substance; response to other organism; response to oxidative stress;response to oxygen-containing compound; tissue development calcium-mediated signaling; cell growth; developmental growth involved in morphogenesis; intracellular transport; membrane organization; organelle localizatio;nresponse to cold; response to endogenous stimulus; response to mechanical stimulus; response to organic substance; response to water deprivation; root epidermal cell differentiation; starch metabolic process

GO componente celular

apoplast;Golgi apparatus;planttype cell melliplasmodesma;vac
membrane

heme binding;peroxidase activity;protein binding

;peroxidase membrane

cell wall;;ytoplasmic part; extracellular , bounded organelle

cytosol;nucleus;plasm calcium ion binding;protein activity chune system process; organic substance metabolic process; response to chemica
stimulus; response to other organism

cell part cellular component organization; defense response to bacterium, incompatible interaction; defense response to fungus, incompatible interaction; organ development; regulation of anthocyanin biosynthetic process; regulation of cellular
metabolic process; regulation of defense response; regulation of macromolecule metabolic process; response to cadmium ion; response to organic substance; response to oxygen-containing compound; response to salt stress; response to UV-B, response to virus; signal transduction; systemic acquired resistance

cell wall organization or biogenesis; cellular component organization; defense response to fungus; induced systemic resistance; organ development; regulation of anthocyanin biosynthetic process; regulation of cellular metabolic process; regulation of defense response; regulation of macromolecule metabolic process response to cadmium ion; response to ethylene stimulus; response to oxygencontaining compound; response to UV-B; response to virus; signal transduction;

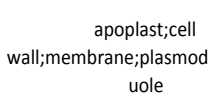

brassinosteroid mediated signaling pathway; cellular component organization:

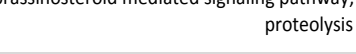

extracellular space;plant-type cell serine-type carboxypeptidase wall;ivacuole activity SCPL-I:;serine

proteolysis cytosol;extracellular region;vacuole serine-type carboxypeptidase activity de II [EC:3.4.16.] SCPLIV; $;$ serine second-messenger-mediated signaling 


\section{Continuação Anexo 6.}

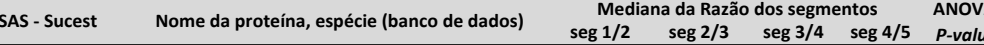

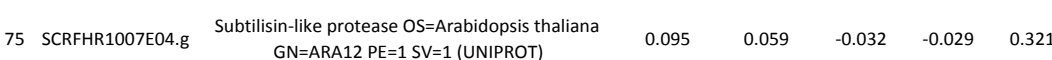

\begin{tabular}{|c|c|c|c|c|c|}
\hline SCCCLR1024E11.g & 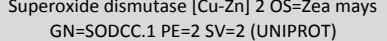 & -0.124 & 0.132 & 0.095 & 0.218 \\
\hline
\end{tabular}

77 SCCCLR1048A06.g Superoxide dismutase(UNIPROT)

$-0.048$

0.132

$0.111 \quad 0.10$

78 SCCCLR2C03D05.

Superoxide dismutase(UNIPROT)

$\begin{array}{rrr}121 & -0.081 & -0.253 \quad 0.508\end{array}$

79 SCAGLR1021H06.8

Thiol protease SEN102 OS=Hemerocallis

$-0.822$

$-0.59$

$-0.249 \quad-0.022$

0.00

\section{0}

80 SCAGLR1043D04.g

$V$-type proton ATPase catalytic subunit $A$

0.09

$-0.120 \quad-0.077 \quad 0.48$

81 SCCCLB1025B04.g
V-type proton ATPase subunit E OS=Citrus limon
GN=VATE PE=2 SV=1 (UNIPROT)

from seed coat; plant-type cell wall biogenesis and modification; polysaccharide metabolic process; proteolysis; regulation of cell proliferation; regulation of meristem growth; response to auxin stimulus; RNA splicing, via endonucleolytic
cleavage and ligation cellular response to copper ion; cellular response to ozone; cellular response to salt stress; cellular response to sucrose stimulus; cellular response to UV-B; defense
response to bacterium; gene silencing by miRNA; oxidation-reduction process; response to bacterium; gene silencing by miRNA; oxidation-reduction process;
removal of superoxide radicals; response to cadmium ion;response to iron ion; toxin
catabolic process

aerobic respiration; defense response to bacterium; embryo development ending in seed dormancy; floral organ abscission; gibberellic acid mediated signaling pathway; gibberellin biosynthetic process; Golgi organization; hyperosmotic response; esponse to salt stress: response to temperature stimulus; response to zinc ion; ubiquitin-dependent protein catabolic process; water transport
uns cellular response to copper ion; cellular response to ozone; cellular response to salt stress; cellular response to sucrose stimulus; cellular response to UV-B; defense response to bacterium; gene silencing by miRNA; oxidation-reduction ; toxin catabolic process

carboxylic acid biosynthetic process; cellular polysaccharide metabolic process; defense response to fungus, incompatible interaction; developmental programmed cell death;;Golgi organization; hydrogen peroxide catabolic process; hyperosmotic salinity response; leaf senescence; plant-type cell wall organization; proteolysis; stimulus; response to gibberellin stimulus; response to red light; response to

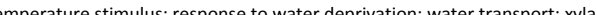
metabolic process

ATP hydrolysis coupled proton transport; ATP metabolic process; calcium ion transport; cell growth; cell morphogenesis; cytoskeleton organization; Golgi ganization; Golgi vesicle transport; hyperosmotic response; pentose-phospha shant, proteasomal protein catabolic process, regulation of biological qualty;

ATP hydrolysis coupled proton transport; ATP synthesis coupled proton transport; calcium ion transport; defense response to bacterium; embryo development ending in seed dormancy;glycolysis; Golgi organization; hyperosmotic
response; plant-type cell wall biogenesis; response to cadmium ion;response to cold

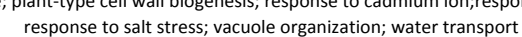

ell wall polysaccharide metabolic process; cellular biosynthetic process; cellular component organization;d efense response to fungus, incompatible interaction ;developmental programmed cell death; hyperosmotic salinity response ;leaf senescence; organic substance biosynthetic process; proteolysis; response to carboxylic acid hosy programmed cell death; glucuronoxylan metabolic process; glycolysis; Golgi organization; hydrogen peroxide catabolic process; hyperosmotic salinity sponse; leaf senescence; plant-type cell wall organization ; proteolysis; regulation osponse to growh, response to cadmium ion, response to ethylene stimulus; water deprivation; water transport; xylan biosynthetic process

GO componente celular

GO função molecular

informaç̃es do kegg

plasma membra

$$
\text { matrix;Golgi serine-type endopeptidase }
$$

activity

$\begin{array}{ccc}\text { apoplast; chloroplast } & \text { copper ion binding:protein } & \text { SOD1; superoxide } \\ \text { dismutase, Cu-Zn }\end{array}$ e;thylakoid;yacuole activity;incion binding family [EC:1.15.1.1]

\section{chloroplast stroma; $\quad$ copper ion binding;superoxide SOD2;superoxide $\begin{array}{ccc}\text { mitochondrion;plastid nucleoid } & \begin{array}{c}\text { copper } \\ \text { dismutase activity }\end{array} & \begin{array}{r}\text { dismutase, Fe-Mn } \\ \text { family [EC:1.15.1.1] }\end{array}\end{array}$}

apoplast; chloroplast stroma; copper ion binding;protein SOD1; superoxide ytosol;nucleus; peroxisome; binding;superoxide dismutase dismutase, Cu-Zn

apoplast; cell wall; CEP;KDEL-tailed binding

apoplast;cell wall;chloroplast envelope; chloroplast
thylakoid; cytosol; Golgi

thylakoid; cytosol; Golgi

transporting ATP synthase

complex; plant-type vacuole;plasma ATP binding;protease ATP synthase activity, PTPeV1A; V-type H+transporting V-type ATPase, V membrane

cytosolic ribosome; Golgi

paratus;mitochondrial protontransporting ATP synthase complex;nucleus;plant-type vacuole membrane;proton-
transporting two-sector ATPase complex, catalytic doman wall;chloroplast; ;ytosoli;endoplasm calcium ion binding;cysteinetype peptidase activity;yrote reticulum;nucleus;plasmodesma; apoplast;cell wall; chloroplast; cytosol;endoplasm calcium ion binding; cysteine- $\quad$ XCP;xylem cysteine

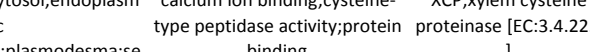
nescence-associated vacuole type peptidase activist
binding

hydrogen-exporting ATPase activity, phosphorylative ATPEV1E; V-type H+. mechanism;proton- transporting ATP

CP:xylem cysteine
[EC:3.4.22.
binding 



\title{
Chapter 13 \\ Using Natural Plant Cell Wall Degradation Mechanisms to Improve Second Generation Bioethanol
}

\author{
Adriana Grandis, Amanda P. de Souza, Eveline Q. P. Tavares \\ and Marcos S. Buckeridge
}

\begin{abstract}
Cell wall hydrolysis is one of the key processes needed for development of the technology for second-generation $(2 \mathrm{G})$ bioethanol production. Thus, finding and characterizing enzymes that can deal with the complexity of the walls has been the main focus of research. As a result, data on pretreatments of many kinds and performances of enzyme cocktails containing glycosyl hydrolases from microorganisms are becoming quickly available. Here we propose that the efficiency of the $2 \mathrm{G}$ process could be increased even further by acquiring control of mechanisms that plants themselves use to degrade their own walls, so that wall loosening provoked by such processes would decrease the energy demand for pretreatments and facilitate hydrolysis. The examined in this chapter are plant-microorganism interaction, cell wall storage mobilization, fruit ripening, abscission, and aerenchyma formation. These systems are seen as having in common the use of modules that are coupled sequentially in order to lead to cell wall modification, including hydrolysis, for performance of different biological functions. These modules are (1) target cells perception of a message from the hormonal balance, (2) cell separation, (3) cell expansion, (4) programmed cell death, (5) hemicellulose-cellulose relaxation/hydrolysis and (6) cellulose hydrolysis. We propose that the use of synthetic biology to transform bioenergy feedstocks could be a route to increase the efficiency of $2 \mathrm{G}$ processes.
\end{abstract}

\subsection{Introduction}

The main bioethanol producers in the world are the US and Brazil, the former producing it from maize starch and the second from sucrose from sugarcane culms. In order to increase bioethanol production without increasing acreage, second

\footnotetext{
A. Grandis · A. P. de Souza · E. Q. P. Tavares · M. S. Buckeridge $(\bowtie)$

Laboratory of Plant Physiological Ecology, Department of Botany, Institute of Biosciences, University of São Paulo, São Paulo, Brazil

e-mail: msbuck@usp.br
} 
generation $(2 \mathrm{G})$ bioethanol technologies could be used. These technologies consist in the production of free fermentable sugars from cell walls. To access these sugars it is of great importance the production of basic scientific information about what the cell walls are like and how enzymes attack each polymer as well as the entire composite.

The production of bioethanol by means of $2 \mathrm{G}$ technologies involves the use of strategies that should modify the organization of cell wall architecture. The socalled $2 \mathrm{G}$ route involves biomass pretreatments in which polysaccharides would become available for enzymatic hydrolysis by application of physical and/or chemical treatments (Soccol et al. 2010; Dos Santos et al. 2011).

Moreover, due to the complex nature of the plant cell wall, degradation of lignocellulosic biomass requires the use of different classes of enzymes that have to be used in high proportions in order to produce enough free sugars for efficient fermentation (Verma et al. 2010). The production of $2 \mathrm{G}$ bioethanol requires ca. 11 millions of filter paper units (FPU) (i.e. $19 \mathrm{~kg}$ ) to produce $84 \mathrm{~L}$ of bioethanol (Himmel et al. 1997, 1999) or 15-25 kg of cellulase per ton of biomass (Carroll and Somerville 2009; Taylor et al. 2008). Furthermore, due to the different compositions of the cell wall polymers, it would still be necessary to prospect for individually different classes of enzymes for characterization and subsequently combine them into cocktails that should be specific for every type of biomass, including the pretreated ones. Thus, one of the first challenges to be faced in order to turn $2 \mathrm{G}$ bioethanol viable commercially is to develop efficient systems of enzymes for biomass degradation (Verma et al. 2010). Due to the high costs and limited capacity for enzyme production, new ways to make biomass available for fermentation could be helpful, since they could hopefully lead to the use of lower proportions of enzymes in the process.

The proposed way to couple pretreatment and hydrolysis has been the use of enzyme cocktails on cell walls of pretreated materials (Fig. 13.1). Such enzyme cocktails are usually artificial assemblies of extracellular proteins produced by microorganisms (Balat 2011). In fact, many initiatives exist to use microorganisms as producers of heterologous glycosyl hydrolases so that enzyme engineering could be used to improve their action.

The sources of enzymes chosen by the scientific community varies, but with the advent of metagenomic techniques, microorganisms and animal genes that encode for glycosyl hydrolases became the main focus for enzyme search in the hope to find new targets that could be somehow more efficient to hydrolyze plant cell walls. This strategy relies mainly on the idea that microorganisms that perform composting of plant residues in the environment and some animal digestive systems are capable to hydrolyze the plant cell walls (Gómez et al. 2008).

Some initiatives exist in which enzymes coding genes from microorganisms have been cloned into plants in order to try to loosen walls and turn them more amenable to hydrolysis (Kaida et al. 2009; Xin et al. 2011). Although expression of the enzymes in vivo have been demonstrated, there is no evidence that these biomasses would be more easily hydrolysed and/or pretreated than biomass derived from untransformed plants. 


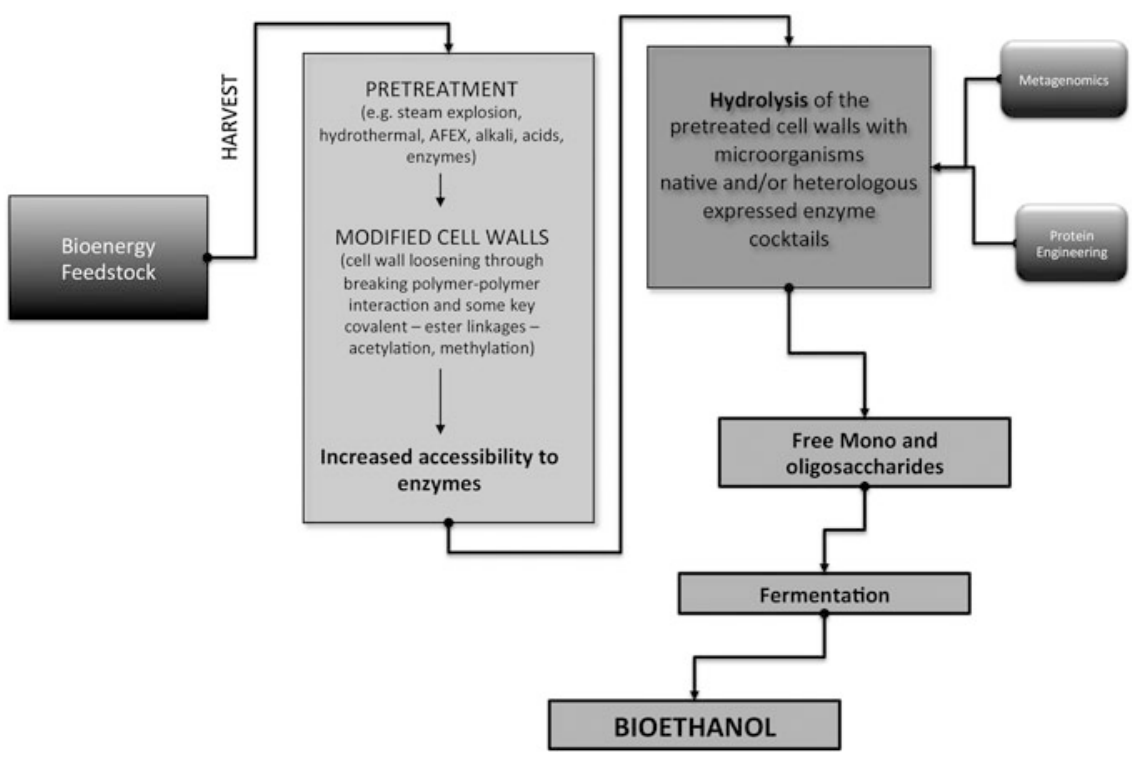

Fig. 13.1 Schematic representation of the second-generation process of bioethanol production, highlighting the different types of pretreatments and hydrolysis

Thus, even with the large effort of the scientific community world wide to improve pretreatment and hydrolysis processes, cell wall recalcitrance to hydrolysis continues to be a barrier to turn the $2 \mathrm{G}$ processes economically viable (Himmel et al. 2007). A common mistake has been to attribute recalcitrance solely to the presence of lignin. However, this recalcitrance is also due to the enormous complexity of the architecture of the cell wall with its several polymers integrated in a composite that has been selected in a way to avoid enzyme attack and degradation.

One additional strategy to be used to improve the knowledge about $2 \mathrm{G}$ processes that has not been consistently thought of, or experimented with the same intensity, is the use of hydrolytic systems that plants themselves possess. Some of them can be quite efficient to degrade and/or change the architecture of cell walls and might lead to important additions to $2 \mathrm{G}$ processes, especially with the advent of the synthetic biology era, in which the capacity of changing biological systems (e.g. turning on/off entire biochemical pathways) is expect to be developed.

Similarly to the strategies currently being designed in which biological engineering is going to be used within microorganisms to produce more efficient enzymes, plant biotechnology could help not only by the introduction of genes of animals and/or microorganisms, but also by finding mechanisms of cell wall hydrolysis that already exist in nature. The main mechanisms of this kind known are: (1) plant-microorganism interaction; (2) seed cell wall storage mobilization; (3) fruit ripening, (4) abscission and (5) aerenchyma formation.

In this chapter, we will provide a review of aspects of some representative mechanisms that could be relevant to improve plants so that they would be better 
prepared for pretreatment and hydrolysis. Here, this process will be named biological pretreatment. The idea is that in the future, plants could have some of their hydrolytic processes redesigned to alter some features of the cell walls in the way of turning them more suitable for use in industry, without however loosing the perspective of the technologies current under development for $2 \mathrm{G}$ bioethanol production.

In order to understand how walls can be hydrolysed, some aspects of cell wall composition, structure and architecture will be introduced in the following section. The understanding of the cell wall complexity will allow the reader to appreciate how some natural systems in which walls are modified could be used for biotechnology applications in bioethanol production.

\subsection{Composition, Structure and Architecture of the Plant Cell Wall}

The cell walls are composed of a mixture of polymers, mainly carbohydrates, proteins and secondary metabolites. These polymers interact through a mixture of covalent and non-covalent linkages to form a "supramolecular complex" that is thought to be a multifunctional structure responsible for controlling the mechanical properties of the cell.

In order to elucidate plant cell wall structure and functions, wall scientists have followed some key steps mainly during the second half of the 20th Century. The first step was to set up methods for extraction, determination of composition and structure of wall components. This step was followed by the development of methods to determine the structure (linkage types) and physico-chemical properties of these polymers. All this work culminated in the proposition of a succession of models that pictured a general assembly for the polymers in the wall (Keegstra et al. 1973; McCann and Roberts 1991; Carpita and Gibeaut 1993). Likewise, many aspects of the biochemistry of the wall were developed, culminating in the characterization of several glycosyl hydrolases (e.g. Fry 2004) that correlate with physiological events in plants, which are controlled by plant hormones and environmental cues. With the advance of cellular and molecular biological techniques, part of the wall research community invested in finding and correlating wall structure with genes associated with its metabolism (e.g. Holland et al. 2000; Lima et al. 2001) and also succeeded to find probes (enzymes and monoclonal antibodies) capable to localise wall components in the cell (e.g. Willats et al. 2001; Pattathil et al. 2010).

McCann and Roberts (1991) coined the term "architecture" of the cell wall in a reference to the existence of three different independent domains in the wall: pectin, cellulose-hemicellulose and proteins. This view implies that the three domains might interact and this sole interaction would have emergent properties. Carpita and Gibeaut (1993) showed that at the level of higher plants, the wall structure has different polysaccharides (e.g. arabinoxylan, $\beta$-glucan, xyloglucan and mannan) 
that may play similar functions. Thus, the "architectural" model of the wall points out that cell wall structure is degenerated and that the domains are changing during evolution, i.e. monocots and ferns changed their main hemicelluloses from xyloglucan to arabinoxylan and mannans respectively, with a concomitant decreased pectin domain (Buckeridge 2006; Sarkar et al. 2009).

In higher plants, cellulose, $(1 \rightarrow 4)-\beta$-D-glucan, is the most abundant biological material on earth and in dry wood correspond around of 40-50\% of dry mass. Hemicellulose is the second polysaccharide representing 25-35\% of dry mass and their composition is a mixture of various polymerised monosaccharides, such as xylose and arabinose or glucose, mannose and galactose whose proportions change according to the plant tissue and the species.

The principal hemicelluloses found in nature are xyloglucan, galactomannan or galactoglucomannan, $\beta$-glucan and glucuronoarabinoxylan (GAX). Xyloglucan is a major hemicellulose in the primary walls of flowering plants, all non-monocots and about one-half of monocot species. Some seeds store this polysaccharide in large amounts as a resource for the embryo after germination (Buckeridge et al. 2000a). Xyloglucans typically comprise $(1 \rightarrow 4)-\beta$-D-glucan backbones, with three of every four glucose residues substituted with $(1 \rightarrow 6)-\alpha$-Dxylopyranosides, and some of the xylose residues are further substituted with $(1 \rightarrow 2)-\beta$-D-galactopyranosides. The most widespread technique used for studies on xyloglucan has been the digestion with a Trichoderma endo- $\beta$-glucanase (Anderson and Stone 1975; Tiné et al. 2006). This enzyme hydrolyses xyloglucan polymers only on unbranched glucosyl residues.

The cell walls from grasses (Poales), which are the main plants used in bioenergy, have a distinct architecture when compared with non-monocots and nonCommelinid monocots (Carpita and Gibeaut 1993). Besides the fact that low levels of pectin are present in their walls, grasses contain as their main hemicelluloses the mixed-linked $(1 \rightarrow 3)$, $(1 \rightarrow 4)-\beta$-D-glucan $(\beta$-glucan $)$ and glucuronoarabinoxylan (GAX).

$\beta$-Glucan interlaced by GAX of low degree of substitution and glucomannans, is thought to be tightly associated with the cellulose microfibrils. GAX of higher degree of arabinosyl substitution and some glucomannan constitutes the major pore-determining interstitial material between the microfibrils (see below).

One of the principal enzymes involved in the depolymerization of the endosperm $\beta$-glucan is the $(1 \rightarrow 3),(1 \rightarrow 4)-\beta$-D-glucan endohydrolase, whose activity parallels that of the $B$. subtilis enzyme in that hydrolysis is restricted to $(1 \rightarrow 4)$ - $\beta$-linked glucosyl residues adjacent to $(1 \rightarrow 3)$ - $\beta$-linked residues on the non-reducing side (Parrish et al. 1960). Like the B. subtilis endohydrolase, hydrolysis of $\beta$-glucan with these enzymes yields mostly cellobiosyl- and cellotriosyl-(1 $\rightarrow$ 3)-glucosyl oligosaccharides and smaller amounts of larger cellodextrin-(1 $\rightarrow$ 3)-glucose oligomers (Anderson and Stone 1975).

In GAX, the arabinose residues are attached at the $O-3$ positions along the $(1 \rightarrow 4)$ - $\beta$-linked xylan backbone, and the glucuronic acids are attached to the $O$-2 positions (Carpita 1996). Arabinoxylans are widespread in the walls of all flowering plants, but in nongramineous species the polymer is of much lower abundance, 
and the arabinose residues are attached mostly at the $O-2$ rather than the $O-3$ of the xylosyl units.

A highly substituted GAX (HS-GAX), with six of seven xylosyl branched units is associated with the maximum growth rate of coleoptiles of the grass species Lolium multiflorum and a sequence-dependent xylanase was found that requires branching with GlcA to cleave the neighboring $(1 \rightarrow 4)-\alpha-D$-xylosyl linkage (Nishitani and Nevins 1991). When maize GAXs are depleted of arabinosyl units by mild-acid hydrolysis, this endo- $\beta$-D-xylanase releases a homogeneous group of deca- or undecamers of glucuronoxylan. The xylosyl units are also substituted with acetyl groups at the positions $O-2$ and $O-3$ and some methyl groups have been detected (Carpita 1996).

Porosity of the GAX domain could be determined by the extent of removal of the appendant units. Some highly substituted GAX remain intercalated in the small amount of pectins that are also found in the primary wall. Because $\beta$-glucans are thought to be tightly associated with individual cellulose microfibrils (Carpita et al. 2001), GAX might be the main molecule in the interstitial space. However, Buckeridge and Crivellari (unpublished) have recently performed experiments with sugarcane walls that did not support this hypothesis. When isolated walls (alcohol insoluble residues) of leaves and culms of sugarcane were treated with lichenase (a glycosyl hydrolase that attacks specifically $\beta$-glucan), most of the polymer present in the walls was hydrolyzed and, at the same time, its retrieval did not interfere in the action of endo $\beta$-xylanase on the wall. Also, De Souza et al. (2013) observed that $\beta$-glucans in sugarcane walls are lightly associated with cellulose and/or the cellulose-hemicellulose matrix in the wall. These data suggests that in sugarcane, although $\beta$-glucan is present in some association with other polymers in the wall, they seem to be free for enzyme hydrolysis whereas GAXs are likely to be strongly bound to other polymers, probably cellulose.

Another distinctive feature of Poales and their relatives is the enrichment of aromatic substances in nonlignified walls (Carpita 1996). A large portion of the aromatic substances is esters of hydroxycinnamates (Harris and Hartley 1980). The GAXs are cross-linked in walls by both esterified and etherified hydroxycinnamates and by other phenolic substances, as ferulic acid (Iiyama et al. 1994).

On the basis of the knowledge of the structure of the cell wall polysaccharides, the mode of action of the glycosyl hydrolases and also the genes that encode for these enzymes, it is now possible to design routes that can deal with the complex hydrolysis mechanisms of either the less complex seed polysaccharide degrading systems or even to access more complex wall systems such as the ones from grasses. The latter is not an easy task as relatively little knowledge exists about the composition, structure and architecture of the wall of most bioenergy feedstocks.

The cell walls of one of the most important bioethanol feedstocks, sugarcane, has been recently analysed by De Souza et al. (2013), who demonstrated that hemicelluloses are quantitatively the main components of the cell walls. Regarding carbohydrates alone, whereas hemicelluloses account for ca. $60 \%$ of the walls, cellulose makes around $30 \%$, and pectins about $10 \%$. Hemicelluloses are of three types: arabinoxylan, $\beta$-glucan and xyloglucan, the former being about 
$50 \%$ of the hemicelluloses with the other two types sharing the rest in equal proportion. These authors highlighted the elevated complexity of cell walls and proposed a model for enzyme hydrolysis in which phenylpropanoids in the wall would have to be retrieved first in order to open the way for carbohydrate specific enzymes, pectins being the first to be attacked, followed by the members of the cellulose-hemicellulose matrix.

In summary, cell wall hydrolysis for bioenergy production purposes can be thought of as a procedure capable to disassemble cell wall architecture so that individual polysaccharides would be available to hydrolases. The goal of the process is the production of fermentable monosaccharides. On the other hand, even if the cell wall architecture can be dismantled, the polysaccharides released would still offer the challenge related to their branching patterns, which are different for every polysaccharide, resulting in a rather large diversity of combinations that are named fine structures.

Although the structure of cell wall polymers have been studied for several species, less attention is given to fine structure studies. Since the fine structure of polysaccharides could involve a formation of a glycomic code and interfere in hydrolysis efficiency (De Souza and Buckeridge, unpublished), the understanding of branching patterns and its combinations could be an important issue for 2 nd generation processes (see topic 13.4).

In order to illustrate how natural systems could be helpful in bioenergy sector, in the following sections we will discuss five major systems existent in nature, which include cell walls modifications by enzymes produced for specific situations. It must be highlighted here that these items do not intend to review every biological process exhaustively, but only give key information that are relevant for the mechanisms of cell wall modifications (including hydrolysis) that could be used to transform plants and make them more suitable as bioenergy crops.

\subsection{Cell Wall Degradation During Plant-Microorganism Interaction}

When a pathogen invades a plant tissue, a biochemical conflict takes place, in which host and invader will produce a series of substances, the former to defend itself and the latter to penetrate in the cells (Garcia-Brugger et al. 2006). Among the strategies used by both organisms there are cell wall hydrolases (Walton 1994). In this way, the process of plant-microorganism interaction offers an opportunity to find ways to efficiently disassemble the plant cell wall. Both, saprophytic and pathogenic microorganisms produce extracellular enzymes that can degrade plant polysaccharides. These microorganisms, including bacteria and fungi, and also invertebrates as nematodes can digest cell wall polymers in order to obtain sugars and energy for their growth as well as to penetrate and colonize the cells in a plant tissue (Walton 1994; Annis and Goodwin 1997). In most cases, plants will respond with a reaction named hypersensitivity, which includes programmed cell 
death and with that can restrict the infectious region to a small area surrounding the infection. However, in these cases, pathogens can use this opportunity to feed on dead cells and gain nutrients and with that they may become even more invasive (Greenberg and Yao 2004).

The first class of cell wall hydrolases produced by the pathogen is the pectinases (Tomassini et al. 2009). They are thought to loosen the tissue through digestion of the middle lamella and consequently kill the plant cells that they attack (Cooper 1983). The pectinases known to be involved in fungal and bacterial invasion are endo- and exo-polygalacturonases, pectate-lyases, and pectin methylesterases (Walton 1994; Lagaert et al. 2009). It is also believed that even saprophytes need to use cell wall degradation strategies in order to establish interaction with the plant and for that they also produce pectinases (e.g. Marques et al. 2006).

Pectins are polysaccharides that control cell wall porosity. Some studies demonstrated that the porosity of the substrate walls is the main limiting factor in the enzymatic hydrolysis of lignocellulosic biomass (Chandra et al. 2007). Thus, the knowledge about how microorganisms use the pectinases to invade the plant could be a way to improve the biomass hydrolysis to $2 \mathrm{G}$ bioethanol.

Futhermore, several other enzymes that are able to hydrolyse cell walls can be produced by microorganisms. Recently, the need for enzymes to be used in the production of bioethanol from biomass led many groups to produce a large amount of scientific information about glycosyl hydrolases from microorganisms. The isolation and characterization of enzymes as well as cloning their genes, open a way to engineering those derived from microorganisms, i.e. modify them to perform hydrolysis more efficiently (Serpa and Polikarpov 2011; Ward 2011). Then, new cocktails of enzymes could be designed that would efficiently produce free fermentable sugars for bioethanol production. A review of the enzymes from microorganisms used for bioenergy has been recently published (Polizeli et al. 2011).

\subsection{Seed Cell Wall Storage Mobilization}

Cell Wall Storage Polysaccharides (CWSP) are found as the principal storage compound in seeds of many taxonomically important groups of plants. These groups developed extremely efficient biochemical mechanisms to disassemble cell walls and use the products of hydrolysis for growth. During evolution, several different groups of polymers have been selected as reserves (e.g. mannans, galactomannans, galactoglucomannans, arabinogalactans and xyloglucans) (Buckeridge et al. 2000a, 2000b; Buckeridge 2010). The selective pressures that ended up producing CWSP were directed towards an increase their proportion by introducing a storage cell wall between already existent primary walls (Tiné, Braga, Pattathil, Hahn and Buckeridge, unpublished).

The CWSP have different chemical structures that are related with different biological functions. Mannans and galacto- and glucomannans that are present in palm and coffee seeds and lettuce and tomato respectively are insoluble in water 
and display strong intermolecular interaction. Because of these characteristics, their biological function is usually associated with conferring hardness to plant tissues. Endo- $\beta$-mannanase is the principal enzyme involved in mannan hydrolysis in all species studied and several genes have been cloned whose expression is specific to the seed (Bewley et al. 1997; Lisboa et al. 2006; Gong and Bewley 2007).

In legumes, the main function of the endospermic cell walls appear to be storage, with the yield of galactomannan reaching more than $30 \%$ of the seed dry weight in many species (Buckeridge et al. 2000a). These walls are thickened with galactomannan and in certain cases (e.g. Trigonella foenum-graecum and Schyzolobium parayba) the protoplasm disappears, giving place to the storage wall. In these cases, the endosperm is non-living and degradation is performed by three enzymes ( $\alpha$-galactosidase, endo- $\beta$-mannanase and exo- $\beta$-mannosidase) made in the aleurone layer (Reid 1971; Buckeridge and Dietrich 1996).

Differently from being stored in the endosperm, arabinogalactan and xyloglucans are stored in cotyledons. This is extremely relevant because the cotyledon is, evolutionarily speaking, an adapted leaf and the integration of the metabolism of these polysaccharides with the entire plant is likely to preserve several features of the leaf cell walls.

Pectin polymers are also found as cell wall storage polysaccharides, notably arabinogalactan (Buckeridge et al. 2000b). The cotyledons of lupins (especially Lupinus angustifolius) have been used as a model to study mobilization of this polymer.

Lupinus angustifoluis seeds accumulate high proportions of galactan (Buckeridge and Reid 1994). These authors showed that an exo- $\beta-(1,4)$ galactanase purified from $L$. angustifolius seed acts specifically on this type of galactan. This enzyme is analogous to galactanases found in fruits (TBG4 in tomato for example-see below) where it is thought to play a major function in the changes of porosity in cell walls (Brummell 2006).

Of the CWSP known, xyloglucan seems to be the more complex in most senses. Its basic structure is similar to the primary wall xyloglucans. They have a backbone composed of $(1 \rightarrow 4)-\beta$-linked glucan (like cellulose) with regular branching with $(1 \rightarrow 6)$ - $\alpha$-linked xylosyl residues that can be branched further with $(1 \rightarrow 2)$ - $\beta$-linked galactosyl residues. There is no case reported where fucose was detected in storage xyloglucan. Four enzymes responsible for storage xyloglucan degradation have been detected, purified and characterized ( $\alpha$-xylosidase, $\beta$-galactosidase, $\beta$-glucosidase and xyloglucan-endo- $\beta$-glucanase, latter on renamed xyloglucan transglucosylase/hydrolase (XTH) (Buckeridge et al. 2000a; Buckeridge 2010).

In Hymenaea, Buckeridge et al. (1997) discovered that storage xyloglucan contains two types of constitutive blocks in the main chain, i.e., XXXG and XXXXG. Later on, Tiné et al. (2006) showed that these blocks are not combined randomly in the polymer molecules, which led to the proposition that storage xyloglucans might have a combination of branching patterns that forms a code that have to be decrypted by the enzymatic system in order to be hydrolysed (Buckeridge 2010). Indeed, the fact that branching of cell wall polymers might not be random has been also observed early on for galactomannans (Reid and Edwards 1995). 
As this kind of information is not available in most cases, research should be urgently directed to that in order to complement the efforts in the search for new enzymes as well as enzyme engineering.

\subsection{Fruit Ripening}

During ripening, the cells of fruits display changes in cell walls so that the final result will afford the release of seeds for dispersion. Several species have been adapted to human consumption and became sources of food, being nowadays extremely important in agriculture. That is the case of tomato, apple, pear, melon, papaya, grape to name but a few. Due to the economic importance of fruits, development and ripening have been intensively studied, with tomato being one of the most studied fruit regarding studies of cell wall changes related to texture (Brummell and Harpster 2001; Brummell 2006). Changes in fruit texture that occur during ripening in many cases lead to softening, this process being slightly different for each species (Harker et al. 1997; Brummell 2006). Nonetheless, in all cases the texture is related to changes in cell walls that are associated with the production of several hydrolases. Due to the fact that enzymes can act to hydrolyse fruit cell wall polysaccharides and/or to allow structural changes that modify the mechanical properties of plant tissues, fruit systems can be considered as an opportunity to find mechanisms of cell wall degradation in plants that could help developing biotechnology for bioenergy.

In fruit systems, the most studied degradation process is the activity of endopolygalacturonases, pectin methylesterases and $\beta$-galactosidases on pectic matrix of the walls. Together with the detection of enzyme activities, changes in cell walls of tomato are consistent with a large decrease in uronic acid as well as even larger decreases in galactose in wall fractions (Ahmed and Labavitch 1980; Rose et al. 1998; Brummell and Harpster 2001; Brummell 2006).

It has been demonstrated that pectinases are associated with ripening and softening through degradation of endopolygalacturonases present in the middle lamella. The action of this enzyme is thought to lead to cell separation, a phenomenon that is linked to the subsequent softening of the fruits and change in their texture and taste (Fray and Grierson 1993; Barsan et al. 2010).

The xyloglucan-cellulose network has also been pointed out as an important target in ripening (Rose and Bennett 1999; Brummell 2006). These authors highlight the role of expansions and XTHs in the process and the former authors even compare the process of fruit ripening with the cell expansion system in hypocotyls. Brummell (2006) reviewed fruit ripening from the viewpoint of the wall changes, putting forward the idea that whereas pectin degradation varies among different fruit species (Brummell 2006), the xyloglucan-cellulose network seems to undertake changes that are much more consistent among species. However, the author also highlights the fact that, contrarily to what has been observed for pectins, xyloglucan small fragments have not been detected. Thus, the effects of expansin and enzymes on the xyloglucan-cellulose matrix seem to be more 
towards a relaxation of this matrix rather than hydrolysis. This seems to lead to cell wall swelling that happens concomitantly with pectin solubilization.

The increase in pore sizes, thought to be related to the attack of exo- $\beta$ galactanase in pectin matrix (Brummell 2006), probably opens the way for expansions, XTHs, cellulases, as well as other debranching enzymes, that will attack the cellulose-hemicellulose matrix of the wall, finally changing wall texture as a whole. Indeed, according to Carpita et al. (1979), pore sizes of the walls in plant tissues would be in the range of 35-40 $\AA$, whereas the glycosyl hydrolases stoke radius [e.g. a $20 \mathrm{kDa}$ protein would be approximately $2.5 \mathrm{~nm}$ according to Carroll and Somerville (2009)] is in general higher than the pore sizes, so that this is a clear limitation for penetration of enzymes in the cell wall matrix.

Although endo- $\beta$-glucanases have been found to increase during fruit ripening, very little evidence has been produced that cellulose would be hydrolysed. However, it has been speculated that cellulases would be capable to act on the surface of microfibrils (Brummell 2006) without, however, any assignment of a function for this event.

In spite of the fact of hydrolysis, in a broad sense, being the main process in course during fruit ripening, other steps such as cell separation and expansion, have been observed (Brummell 2006). On the other hand, differently from some other cell wall degradation processes such as aerenchyma formation and abscission (see below), fruit ripening seems do not include programmed cell death.

From a general point of view, fruit ripening is a process in which walls are firstly attacked by pectinases that increases wall porosity, probably allowing the action of other enzymes like XTHs and endo- $\beta$-glucanases that will transform the cellulose-hemicellulose matrix, promoting swelling and increasing even more wall porosity. The extensins that bind to the cellulose-hemicellulose matrix of the wall also could participate of these processes, being probably the first proteins to interact with the wall matrix. Thus, the cell wall alteration plus a higher hydration capacity given by the presence of pectins with lower molecular weight modifies fruits softening.

All this knowledge is extremely useful for bioenergy purposes, as it makes possible to understand details of how plants can manipulate their own walls. These events could be compared with the ones that occur during biomass pretreatment process used to achieve the $2 \mathrm{G}$ bioethanol. The possibility of applying such knowledge in bioenergy crops to produce similar effects in grass stems cell walls (e.g.) could lead to the establishment of a biological pretreatment that could be implemented using synthetic biology tools in the future.

\subsection{Abscission}

Abscission is a general term applied to the processes that takes place during the detachment of leaves, fruits, seeds and also cotyledons, lateral branches and many reproductive structures. In all cases studied, extremely precise biochemical pathways lead to cell wall modification and breakdown in order to form a fracture line 
known as the abscission zone. The events that occur during abscission and dehiscence processes are cleary related to cell wall modification, in a very similar way to the other ones reported in this chapter.

Roberts et al. (2002), highlight the facts that endopolygalacturonases and endo$\beta$-glucanases are closely related to the processes of cell separation. In fruits like tomato, silencing of abscission-related polygalacturonases (e.g. TAPG1) led to a delay in abscission and increased the force needed to break the abscission zone in explants treated with ethylene (Jiang et al. 2008).

In the abscission zone, cortex cells of different plant tissues are thought to be positionally differentiated target cells that will receive the signal from hormones (ethylene, auxin, abscisic acid, gibberellin) in such a balance that the cross talk among these will lead to transdifferentiation and finally to abscission. McManus et al. (1998) demonstrated the existence of transdifferentiation in mature cortical cells of bean abscission tissues. According these authors, this means that cells from the cortex of some plant tissues have the flexibility to differentiate into functionally competent ethylene-responsive cells that exhibit a gene expression compatible with an abscission cell.

Although not reported in most cases, cell wall degradation is thought to occur during abscission, since detection of activity of endo- $\beta$-glucanase has been reported for many abscission systems (Roberts et al. 2002). Also, accumulation of mRNA related with genes encoding Cel1 and Cel4 in tomato fruit and flower abscission zones have been reported (Gonzáles-Carranza et al. 1998).

The similarity of this process with the ones described above is remarkable. Abscission is widespread in plants, occurring in many different tissues of different organs in plants. It includes wall separation and expansion, which are associated with pectin degradation as well as modifications in the cellulose hemicellulose matrix. However, programmed cell death has not been reported for abscission processes, according to the literature revised for this chapter. Thus, there seems to be a great variety of combinations of action of hydrolases to perform cell separation and hydrolysis so that it could be used to design technologies associated to $2 \mathrm{G}$ bioethanol production.

\subsection{Aerenchyma Formation}

Aerenchyma comprises a series of interconnected gas chambers developing on parenchymatic tissue (cortex) of shoots and roots as a result of sequencial events, showing typical features of a programmed cell death process. Its formation is regarded as a response to oxygen shortage (Gunawardena et al. 2001a), exogenous ethylene (Gunawardena et al. 2001b), nitrogen, phosphorus and/or sulphur starvation (He et al. 1994; Siyiannis et al. 2011), mechanical impedance (He et al. 1996b), oxidative stress (Steffens et al. 2011) and osmotic stress (Karahara et al. 2012). 
In opposition to the inducible aerenchyma, the constitutive formation is commonly observed in aquatic species as Juncus effusus (Visser and Bögemann 2006) and Sagittaria lancifolia (Schussler and Longstreth 2000), and also in maize relatives (Mano et al. 2007) and in rice wetland species (Justin and Armstrong 1991), independently of environmental stimuli. In both cases, its development lies upon a cell separation process termed schizogeny (thought of as a cell separation process that does not include cell wall hydrolysis). Alternatively, for the lysogenic process (i.e. cell separation followed by cell wall hydrolysis) to take place, the cells targeted to form aerenchyma clearly undergo a programmed cell death. It is essential to mention that both processes rely on polysaccharide hydrolysis, whereas the cell separation in schizogenous aerenchyma formation depends on middle lamella degradation. As for the lysogenous process, cell wall modifications occur and for that a wide array of enzymes would be required.

Concerning cell wall modifications, most of the aerenchyma-related data is restricted to the lysigenic and inducible formation in maize roots. As reported for other cell degradation events, in this model the inductive role is played by ethylene (He et al. 1992, 1996a; Gunawardena et al. 2001a). One of the earliest signs of aerenchyma formation is the ethylene accumulation, followed by cell death and endo- $\beta$-glucanases activity (Kawase 1979; He et al. 1996a). Indeed, inhibitors of cell death or ethylene biosynthesis block the enhancement of endo- $\beta$-glucanases activity (He et al. 1994, 1996a), suggesting the coupling between cell wall degradation, ethylene signalling and programmed cell death.

Another potentially degradative enzyme associated with aerenchyma formation is endo- $\beta$-xylanase. The rising activity levels of this enzyme were obtained in waterlogged maize roots, coinciding with the rising of ethylene levels (Bragina et al. 2001). Also concerning ethylene induction, the role of XTH, a putative cell wall loosening enzyme, was evaluated during aerenchyma formation. Transcripts of certain $\mathrm{XTH}$ accumulated in flooded maize roots forming aerenchyma, reaching its maximum within $12 \mathrm{~h}$ and remaining high for $144 \mathrm{~h}$ during flooding. On the other hand, the inhibition of ethylene synthesis blocked any rise of this transcript accumulation, while exogenous ethylene led to $X T H$ transcript accumulation even under aerobic conditions (Saab and Sachs 1996). A transcriptional analysis corroborated the induction of XTH expression during the aerenchyma formation in maize roots, as well as for endo- $\beta$-glucanase (Rahji et al. 2011).

Even though the enzymatic or transcriptional approaches have been used to suggest the link between a set of glycosil hydrolases and aerenchyma formation, to our knowledge, data regarding cell wall modifications in situ have been reported only by Gunawardena et al. (2001b), who documented the distinctive levels of methyl esterification changing in the middle lamella in cross sections of the cortex of the maize root along aerenchyma formation. These authors observed that those changes initiated before ultrastructural modifications typical of cells undergoing programmed cell death that have been reported in a previous work (Gunawardena et al. 2001a). Indeed, rise in the expression of pectin methyl esterases, pectate lyase and an endopolygalacturonase have been observed during aerenchyma formation (Rahji et al. 2011). These data not only corroborate the existence of 
homogalacturonan modifications but also suggest that more severe changes on the cell wall structure and not only on the middle lamella can occur. We have observed a similar pattern of events in sugarcane roots, not only with the pectinases, but also with the observation of the rise in gene expression of several genes that encode hemicellulases (e.g. lichenase, endo- $\beta$-xylanase, XTH, $\beta$-glucosidase-unpublished results).

Gunawardena et al. (2001a) reported the formation of vesicles and vacuole rupture while the cell wall appeared intact. It is reasonable to hypothesize that the release of hydrolytic enzymes in this step could be responsible for the cell wall degradation (Bouranis et al. 2007).

The data produced that are related with aerenchyma formation to date indicates that this phenomenon is similar to the other processes discussed above in the sense that cell walls are modified, including cell separation, hemicellulose-cellulose matrix relaxation and perhaps some hydrolysis of cellulose. Thus, the knowlegde about aerenchyma formation can also be considered as a possible target for use in biotechnology that includes cell wall modifications for bioenergy purposes. Recently we have produced a consistent set of results describing events during the aerenchyma formation in sugarcane roots. We found that the events are essencially similar to maize (e.g.), with the exception that in sugarcane it is constitutively activated. Our results (manuscripts in preparation) show very clearly that cell separation, programmed cell death, hemicellulose-cellulose changes and some attack to cellulose occurs in sugarcane. We are now searching for the transcription factors responsible for regulating this processes aiming at possibly inducing them in culms so that this process might be used as a biological pretreatment in the future.

\subsection{Cell Wall Modifications in Natural Systems in the Context of Bioenergy}

As mentioned above, in order to establish $2 \mathrm{G}$ bioethanol production, the retrieval of energy from wall polymers would have to include cell wall modification. From the different systems discussed along this chapter, it is possible to think of combining some of them in order to help increasing the production of bioethanol from bioenergy feedstocks that are being studied for use in $2 \mathrm{G}$ processes.

In Table 13.1 the different modules that plants apparently use to transform their cell walls in order to perform different biological functions are shown in perspective. Six events seem to be common to most of the natural processes that clearly involve modifications in cell walls. Some of these events have been investigated more deeply and others are implied, but not proven, as no direct experimental evidences have been produced for them yet. In Table 13.1, the events are placed in an order (from left to right) that they seem to occur in all systems. However, some steps are missing in some of the processes (e.g. cell separation in storage cell wall mobilization and programmed cell death in fruit ripening). 
Table 13.1 Correlation among situations that include cell wall modifications and natural events in plant biology where these situations are key to biological function

\begin{tabular}{|c|c|c|c|c|c|c|}
\hline Processes & $\begin{array}{l}\text { Target } \\
\text { cells }\end{array}$ & $\begin{array}{l}\text { Cell } \\
\text { separation }\end{array}$ & $\begin{array}{l}\text { Cell } \\
\text { expansion }\end{array}$ & $\begin{array}{l}\text { Programmed } \\
\text { cell death }\end{array}$ & $\begin{array}{l}\text { Hemicellulose } \\
\text { hydrolysis }\end{array}$ & $\begin{array}{l}\text { Cellulose } \\
\text { hydrolysis }\end{array}$ \\
\hline $\begin{array}{l}\text { Plant } \\
\text { microorganism } \\
\text { interaction }\end{array}$ & $?$ & YES & $?$ & YES & YES & YES \\
\hline $\begin{array}{l}\text { Storage cell wall } \\
\text { mobilization }\end{array}$ & $?$ & $\mathrm{NO}$ & YES & $?$ & YES & $?$ \\
\hline Fruit ripening & YES & YES & YES & $\mathrm{NO}$ & YES & YES/NO \\
\hline Abscission & YES & YES & YES & $?$ & YES & YES \\
\hline $\begin{array}{l}\text { Aerenchyma } \\
\text { formation }\end{array}$ & YES & YES & YES & YES & YES & $?$ \\
\hline
\end{tabular}

$\mathrm{YES}=$ there is literature showing that it occurs in most (or all) systems studied; $\mathrm{NO}=$ not observed in the systems studied to date; YES/NO = observed only in some of the systems studied to date; ? = not reported to occur to date

The combination of events is consistent with a chain of processing steps that would follow a sequence of modifications in the walls that are apparently similar in the five processes reviewed in this chapter. The general idea is that in a parenchymatic tissue, a given group of cells would be targeted to start the process (as seen in abscission according to Roberts et al. (2002) and also in aerenchyma formation). The following step would be cell separation that probably involves the action of endo-polygalacturonase(s) on the pectins of the middle lamella. This might be involved with the release of calcium that could be responsible for the signaling related to programmed cell death. The latter seems to occur in parallel with cell expansion and subsequent production and release glycosyl hydrolases that would attack hemicelluloses and cellulose. Every one of these events can be regarded as a module that can or not be used in the complete process that leads to partial or complete cell wall modification.

There are two possible ways to use this information for biotechnology purposes: (1) using them for production of transformed plants; or (2) express some of the hydrolase genes heterologously in order to use them as additions to enzyme cocktails already in use in industry.

For the first option, it should be possible to use the modern tools of synthetic biology in order to induce cell separation and expansion along with some modification of the hemicellulose-cellulose matrix. In this case, plants would produce biomass with the characteristics expected to be analogous to a pretreated biomass material, i.e. materials that would be easily hydrolyzed when being processed in industry, especially during the hydrolysis process. For advancing the second option, some of the enzymes known to be present during hydrolysis processes in bioenergy feedstocks, such as sugarcane, miscanthus, maize, poplar, willow and others should be studied regarding their specificity. Some of these enzymes may be heterologously expressed for production and added to existent cocktails. 
In both cases, there is a relatively long way to go in terms of production of the proof of concepts that will be necessary in order to develop the necessary technologies. However, in some cases, such processes are already present in plants and could be improved using transformation, possibly of transcription factors that trigger the whole process.

It is important to note here that wood feedstocks would probably have to be treated differently regarding the strategies discussed in this chapter. Wood feedstocks have large proportions of dead cells composed of high proportions of cellulose and also with a much higher degree of lignification. For this type of bioenergy feedstock, an addition to the strategy would be the modification of lignin composition to facilitate access to the cell wall polysaccharides, which in fact is currently under investigation (Vanholme et al. 2013). As grasses can have some lignin and phenypropanoids in their cell walls, as well as the cells of the vascular system, whose walls bear many features in common with the wood tissues, the use of the strategies proposed in this chapter for tissues containing large proportion or primary cell walls, along with the ones being developed for decreasing lignin interference, would probably have to be coupled in the future in order to improve bioenergy production even more.

Based on the examples discussed in this chapter, it is very likely that natural processes that involve cell wall modifications in plants will be useful as additions to $2 \mathrm{G}$ bioethanol technologies, via the use of modern molecular techniques associated to systems and synthetic biology.

Acknowledgments This work is part of the production of the Instituto Nacional de Ciência e Tecnologia do Bioetanol-INCT do Bioetanol (FAPESP 2008/57908-6 and CNPq 574002/2008-1) and of the Centro de Processos Biológicos e Industriais para Biocombustíveis-CeProBIO (FAPESP 2009/52840-7 and CNPq 490022/2009-0). Financial support by FAPESP Projects 2010/17104-5, 2010/17070-3, 2011/07586-5 and 2011/02344-3.

\section{References}

Ahmed AE, Labavitch JM (1980) Cell wall metabolism in ripening fruit 1. Cell wall changes in ripening "Bartlett" pears. Plant Physiol 65:1009-1013

Anderson MA, Stone BA (1975) A new substrate for investigating the specificity of glucan hydrolases. FEBS Lett 52:202-207

Annis SL, Goodwin PH (1997) Recent advances in the molecular genetics of plant cell walldegrading enzymes produced by plant pathogenic fungi. Eur J Plant Pathol 103:1-14

Balat M (2011) Production of bioethanol from lignocellulosic materials via the biochemical pathway: a review. Energy Converse Manag 52:858-875

Barsan C, Sanchez-Bel P, Rombaldi C, Egea I, Rossignol M, Kuntz M et al (2010) Characteristics of the tomato chromoplast revealed by proteomic analysis. J Exp Bot 61:2413-2431

Bewley JD, Burton RA, Morohashi U, Fincher GB (1997) Molecular cloning of a cDNA encoding a $(1 \rightarrow 4)-\beta$-mannan endohydrolase from the seeds of germinated tomato (Lycopersicon esculentum). Planta 203:454-459

Bouranis DL, Chorianopoulou SN, Siyiannis VF, Protonotarios VE, Hawkesford MJ (2007) Lysigenous aerenchyma development in roots: triggers and cross-talks for a cell elimination program. Int J Plant Dev Biol 1:127-140 
Bragina TV, Martinovich LI, Rodionova NA, Bezborodov AM, Grineva GM (2001) Ethyleneinduced activation of xylanase in adventitious roots of maize as a response to the stress effect of root submersion. Appl Biochem Microbiol 37:722-725

Brummell DA (2006) Cell wall disassembly in ripening fruit. Funct Plant Biol 33:103-119

Brummell DA, Harpster MH (2001) Cell wall metabolism in fruit softening and quality and its manipulation in transgenic plants. Plant Mol Biol 47:311-340

Buckeridge MS (2006) Implications of emergence, degeneracy and redundancy for the modeling of the plant cell wall. In: Hayashi $\mathrm{T}$ (ed) The science and the lore of the plant cell wall: biosynthesis, structure and function. BrownWalker Press, Boca Raton, pp 41-47

Buckeridge MS (2010) Seed cell wall storage polysaccharides: models to understand cell wall biosynthesis and degradation. Plant Physiol 154:1-7

Buckeridge MS, De Souza AP (2013) The fine structure of cell wall polysaccharides might be related to the existence of a glycomic code in plant cell walls. In: Lam E (ed) Compendium of bioenergy plants: sugarcane (submitted)

Buckeridge MS, Dietrich SMC (1996) Mobilisation of the raffinose family oligosaccharides and galactomannan in germinating seeds of Sesbania marginata Benth (LeguminosaeFaboideae). Plant Sci 117:33-43

Buckeridge MS, Reid JSG (1994) Purification and properties of a novel $\beta$-galactosidase or exo$(1 \rightarrow 4)-\beta$-D-galactanase from the cotyledons of germinated Lupinus angustifolius $\mathrm{L}$. seeds. Planta 192:502-511

Buckeridge MS, Crombie HJ, Mendes CJM, Reid JSG, Gidley MJ, Vieira CJ (1997) A new family of xyloglucan oligosaccharides from cotyledons of Hymenaea courbaril: structure determination of the oligosaccharide XXXXG by enzymatic sequencing and NMR. Carbohydr Res 303:233-237

Buckeridge MS, Dietrich SMC, Lima DU (2000a) Galactomannans as the reserve carbohydrate of legume seeds. In: Gupta AK, Kaur N (eds) Developments in crop science. Elsevier Science BV, Amsterdam, pp 283-316

Buckeridge MS, Santos HP, Tiné MAS (2000b) Mobilisation of storage cell wall polysaccharides in seeds. Plant Physiol Biochem 38:141-156

Buckeridge MS, De Souza AP, Arundale RA, Anderson-Teixeira KJ, DeLucia E (2012) Ethanol from sugarcane in Brazil: a midway strategy for increasing ethanol production while maximizing environmental benefits. GCB Bioenergy 4:119-126

Carpita NC (1996) Structure and biogenesis of the cell walls of grasses. Ann Rev Plant Physiol Plant Mol Biol 47:445-476

Carpita NC, Gibeaut DM (1993) Structural models of primary cell walls in flowering plants: consistency of molecular structure with the physical properties of the walls during growth. Plant J 3:1-30

Carpita NC, Sabularse D, Montezinos D, Delmer DP (1979) Determination of the pore size of cell walls of living plant cells. Science 205:1144-1147

Carpita N, Tierney M, Campbell M (2001) Molecular biology of the plant cell wall: searching for the genes that define structure, architecture and dynamics. Plant Mol Biol 47:1-5

Carroll A, Somerville C (2009) Cellulosic biofuels. Ann Rev Plant Biol 60:165-182

Chandra RP, Bura R, Mabee WE, Berlin A, Pan X, Saddler JN (2007) Substrate pretreatment: the key to effective enzymatic hydrolysis of lignocellulosics? Biofuels Adv Biochem Eng Biotechnol 108:67-93

Cooper RM (1983) The mechanisms and significance of enzymatic degradation of host cell walls by parasites. In: Callow JA (ed) Biochemical plant pathology. Wiley, Chichester, pp 101-137

De Souza AP, Leite DCC, Pattathil S, Hahn MG, Buckeridge MS (2013) Composition and structure of sugarcane cell wall polysaccharides: implications for second-generation bioethanol production. Bioenerg Res 6:564-579

Dos Santos WD, Gómez EO, Buceridge MS (2011) Bioenergy and the sustainable revolution. In: Buckeridge MS, Goldman GH (eds) Routes to cellulosic ethanol. Springer, New York, pp $15-26$

Fray RG, Grierson D (1993) Molecular genetics of tomato fruit ripening. Trends Genet 9:438-443 
Fry S (2004) Primary cell wall metabolism: tracking the careers of wall polymers in living plant cells. New Phytol 161:641-675

Garcia-Brugger A, Lamotte O, Vandelle E, Bourque S, Lecourieux D et al (2006) Early signaling events induced by elicitors of plant defenses. Mol Plant Microbe Interact 19:711-724

Gómez LD, Steele-King CG, McQueen-Mason SJ (2008) Sustainable liquid biofuels from biomass: the writing's on the walls. New Phytol 178:473-485

Gong X, Bewley JD (2007) Shorting out the LeMANs: endo- $\beta$-mannanase genes and their encoded proteins in tomato. Seed Sci Tech 17:143-154

Gonzáles-Carranza ZH, Lozoya-Gloria E, Roberts JA (1998) Recent developments in abscission: shedding light on the shedding process. Trends Plant Sci 3:10-14

Greenberg JT, Yao N (2004) The role and regulation of programmed cell death in plant-pathogen interactions. Cell Microbiol 6:201-211

Gunawardena A, Lan H, Pearce DM, Jackson MB, Hawes CR, Evans DE (2001a) Characterization of programmed cell death during aerenchyma formation induced by ethylene or hypoxia in roots of maize (Zea mays L.). Planta 212:205-214

Gunawardena A, Pearce DM, Jackson MB, Hawes CR, Evans DE (2001b) Rapid changes in cell wall pectic polysaccharides are closely associated with early stages of aerenchyma formation, a spatially localized form of programmed cell death in roots of maize (Zea mays L.) promoted by ethylene. Plant Cell Environ 24:1369-1375

Harker FR, Redgwell RJ, Hallet IC, Murray SH, Carter G (1997) Texture of fresh fruit. Hortic Rev 20:121-124

Harris PJ, Hartley RD (1980) Phenolic constituents of the cell walls of monocotyledons. Biochem Syst Ecol 8:153-160

He CJ, Morgan P, Drew MC (1992) Enhanced sensitivity to ethylene in nitrogen of phosphatestarved roots of Zea mays L. during aerenchyma formation. J Plant Physiol 98:137-142

He CJ, Drew M, Morgan PW (1994) Induction of enzymes associated with lysigenous aerenchyma formation in roots of Zea mays during hypoxia or nitrogen starvation. J Plant Physiol 105:861-865

He CJ, Pinlayson SA, Drew MC, Jordan WR, Morgan PW (1996a) Ethylene biosynthesis during aerenchyma formation in roots of Zea mays subjected to mechanical impedance and hypoxia. J Plant Physiol 112:1679-1685

He CJ, Morgan PW, Drew MC (1996b) Transduction of an ethylene signal is required for cell death and lysis in the root cortex of maize during aerenchyma formation induced by hypoxia. J Plant Physiol 112:463-472

Himmel ME, Adney WS, Baker JO, Elander R, McMillan JD, Nieves RA, Sheehan JJ, Thomas SR, Vinzant TB, Zhang M (1997) Advanced bioethanol production technologies: a prospective. In: Woodward J, Saha B (eds) ACS symposium series, vol 666. American Chemical Society, Washington, DC, pp 2-45

Himmel ME, Ruth MF, Wyman CE (1999) Cellulase for commodity products from cellulosic biomass. Curr Opin Biotechnol 10:358-364

Himmel ME, Ding SY, Johnson DK, Adney WS, Nimlos MR, Brady JW, Foust TD (2007) Biomass recalcitrance: engineering plants and enzymes for biofuels production. Science 315:804-807

Holland N, Holland D, Helentjaris T, Dhugga KS, Xoconostle-Cazares B, Delmer DP (2000) A comparative analysis of the plant cellulose synthase (CesA) gene family. Plant Physiol 123:1313-1323

Iiyama K, Lam TBT, Stone BA (1994) Covalent crosslinks in the cell wall. Plant Physiol 104:315-320

Jiang CZ, Lu F, Imsabai W, Meir S, Reid MS (2008) Silencing polygalacturonase expression inhibits tomato petiole abscission. J Exp Bot 59:973-979

Justin SHFW, Armstrong W (1991) Evidence for the involvement of ethene in aerenchyma formation in adventitious roots of rice (Oryza sativa L.). New Phytol 118:49-62 
Kaida R, Kaku T, Baba K, Oyadomari M, Watanabe T, Nishida K, Kanaya T, Shani Z, Shoseyov O, Hayashi T (2009) Loosening xyloglucan accelerates the enzymatic degradation of cellulose in wood. Mol Plant 2:904-909

Karahara I, Umemura K, Soga Y, Akai Y, Bando T, Ito Y, Tamaoki D, Uesugi K, Abe J, Yamauchi D, Mineyuki Y (2012) Demonstration of osmotically dependent promotion of aerenchyma formation at different levels in the primary roots of rice using a 'sandwich' method and X-ray computed tomography. Ann Bot 110:503-509

Kawase M (1979) Role of cellulase in aerenchyma development in sunflower. Amer J Bot 66:183-190

Keegstra K, Talmadge K, Baurer WD, Albersheim O (1973) Structure of the plant cell walls. Plant Physiol 51:188-196

Lagaert S, Beliën T, Volckaert G (2009) Plant cell walls: protecting the barrier from degradation by microbial enzymes. Stem Cell Dev Biol 20:1064-1073

Lima DU, Santos HP, Tiné MAS, Molle FD, Buckeridge MS (2001) Patterns of expression of cell wall related genes in sugarcane. Gen Mol Biol 24:191-198

Lisboa CGS, Tiné MAS, Buckeridge MS (2006) Endo- $\beta$-mannanase from the endosperm of seeds of Sesbania virgata (Cav.) Pers. (Leguminosae): purification, characterisation and importance for germination and early seedling growth. Braz J Plant Physiol 18:269-280

Mano Y, Omori F, Takamizo T, Kindiger B, Bird R, Loaisiga C, Takahashi H (2007) QTL mapping of root aerenchyma formation in seedlings of a maize e rare teosinte "Zea nicaraguensis" cross. Plant Soil 295:103-113

Marques MR, Buckeridge MS, Braga MR, Dietrich SMC (2006) Characterization of an extracellular endopolygalacturonase from saprobe Mисоr ramosissimus Samutsevitsch and its action as trigger of defensive response in tropical plants. Mycopathologia 162:337-346

McCann MC, Roberts K (1991) Architecture of the primary cell wall. In: Lloyd CW (ed) The cytoskeletal basis of plant growth and form. Academic Press, London, pp 109-129

McManus MT, Thompson DS, Merriman C, Lyne L, Osborne DI (1998) Transdifferentiation of mature cortical cells to functional abscission cells in bean. Plant Physiol 116:891-899

Nishitani K, Nevins DJ (1991) Glucuronoxylan xylanohydrolase: a unique xylanase with the requirement for appendant glucuronosyl units. J Biol Chem 266:6539-6543

Ong RG, Chundawat SPS, Hodge DB, Keskar S, Dale B (2013) Linking plant biology and pretreatment: understanding the structure and organization of the plant cell wall and interactions with cellulosic biofuel production. In: Carpita NC, Buckeridge MS, McCann MC (eds) Plants and bioenergy. Springer, New York

Parrish FW, Perlin AS, Reese ET (1960) Selective enzymolysis of poly- $\beta$-D-glucans, and the structures of the polymers. Can J Chem 38:2094-2104

Pattathil S, Avci U, Baldwin D, Swennes AG, McGill JA, Popper Z et al (2010) A comprehensive toolkit of plant cell wall glycan-directed monoclonal antibodies. Plant Physiol 153:514-525

Polizeli MLTM, Corrêa ECP, Polizeli AM, Jore JA (2011) Hydrolases from microorganisms used for degradation of plant cell wall and bioenergy. In: Buckeridge MS, Goldman GH (eds) Routes to cellulosic ethanol. Springer, New York, pp 117-136

Rahji I, Yamauchi T, Takahashi H, Nishiuchi S, Shiono K, Watanabe R, Mliki A, Nagamura Y, Tsutsumi N, Nishizawa NK, Nakazono M (2011) Identification of genes expressed in maize root cortical cells during lysigenous aerenchyma formation using laser microdissection and microarray analyses. New Phytol 190:351-368

Reid JSG (1971) Reserve carbohydrate metabolism in germinating seeds of Trigonella foenungraecum L. (Legum). Planta 100:131-142

Reid JSG, Edwards M (1995) Galactomannans and other cell wall storage polysaccharides in seeds. In: Stephen AM (ed) Food polysaccharides and their applications. Marcel Dekker, New York, pp 155-186

Roberts JA, Elliott KA, Gonzalez-Carranza Z (2002) Abscission, dehiscence, and other cell separation processes. Ann Rev Plant Biol 53:131-158 
Rose JKC, Bennett AB (1999) Cooperative disassembly of the cellulose-xyloglucan network of plant cell walls: parallels between cell expansion and fruit ripening. Trends Plant Sci 4:176-183

Rose JKC, Hadfield KA, Labavitch JM, Bennett AB (1998) Temporal sequence of cell wall disassembly in rapidly ripening melon fruit. Plant Physiol 117:345-361

Saab IN, Sachs MM (1996) A folding-induced xyloglucan endo-transglycosylase homolog in maize is responsive to ethylene and associated with aerenchyma. J Plant Physiol 112:385-391

Sarkar P, Bosneaga E, Auer M (2009) Plant cell walls throughout evolution: towards a molecular understanding of their design principles. J Exp Bot 60:3615-3635

Schussler EE, Longstreth DJ (2000) Changes in cell structure during the formation of root aerenchyma in Sagittaria lancifolia (Alismataceae). Amer J Bot 87:12-19

Serpa VI, Polikarpov I (2011) Enzymes in bioenergy. In: Buckeridge MS, Goldman GH (eds) Routes to cellulosic ethanol. Springer, New York, pp 99-116

Siyiannis VF, Protonotarios VE, Zechmann B, Chorianopoulou SN, Müller M, Hawkesford MJ, Bouranis DL (2011) Comparative spatiotemporal analysis of root aerenchyma formation processes in maize due to sulphate, nitrate or phosphate deprivation. Protoplasma 249:671-686

Soccol CR, Vandenberghe LPS, Medeiros ABP, Karp SG, Buckeridge MS, Ramos LP, Pitarelo AP, Ferreira-Leitão V, Gottschalk LMF, Ferrara MA (2010) Bioethanol from lignocelluloses: status and perspectives in Brazil. Biores Technol 101:4820-4825

Steffens B, Geske T, Sauter M (2011) Aerenchyma formation in the rice stem and its promotion by $\mathrm{H}_{2} \mathrm{O}_{2}$. New Phytol 190:369-378

Taylor LE II, Dai Z, Decker SR, Brunecky R, Adney WS, Ding SY, Himmel ME (2008) Heterologous expression of glycosyl hydrolases in planta: a new departure for biofuels. Trends Biotechnol 26:413-424

Tiné MAS, Silva CO, Lima DU, Carpita NC, Buckeridge MS (2006) Fine structure of a mixed-oligomer storage xyloglucan from seeds of Hymenaea courbaril. Carbohydr Polym 66:444-454

Tomassini A, Sella L, Raiola A, D'Ovidio R, Favaronl F (2009) Characterization and expression of Fusarium graminearum endo-polygalacturonases in vitro and during wheat infection. Plant Pathol 58:556-564

Vanholme B, Cesarino I, Goeminne G, Kim H, Marroni F, Van Acker R, Vanholme R, Morreel K, Ivens B, Pinosio S, Morgante M, Ralph J, Bastien C, Boerjan W (2013) Breeding with rare defective alleles (BRDA): a natural Populus nigra HCT mutant with modified lignin as a case study. New Phytol 198:765-776

Verma D, Kanagaraj A, Jin S, Singh ND, Kolattukudy PE, Daniell H (2010) Chloroplast-derived enzyme cocktails hydrolyse lignocellulosic biomass and release fermentable sugars. Plant Biotechnol J 8:332-350

Visser EJ, Bögemann GM (2006) Aerenchyma formation in the wetland plant Juncus effusus is independent of ethylene. New Phytol 171:305-314

Walton JD (1994) Deconstructing the cell wall. Plant Physiol 104:1113-1118

Ward R (2011) Cellulase engineering for biomass saccharification. In: Buckeridge MS, Goldman GH (eds) Routes to cellulosic ethanol. Springer, New York, pp 137-153

Willats WGT, McCartney L, Mackie W, Knox P (2001) Pectin: cell biology and prospects for functional analysis. Plant Mol Biol 47:9-27

Xin Z, Watnabe N, Lam E (2011) Improving efficiency of cellulosic fermentation via genetic engineering to create "smart plants" for biofuel production. Enzymes in bioenergy. In: Buckeridge MS, Goldman GH (eds) Routes to cellulosic ethanol. Springer, New York, pp 183-199 